UNIVERSIDADE DE SÃO PAULO

INSTITUTO DE PSICOLOGIA

ELISABETE JOYCE GALHARDO TAMAGNINI

A PSICODINÂMICA DO PACIENTE CARDIOPATA:

CONTRIBUIÇÕES DA PSICANÁLISE À CARDIOLOGIA

SÃo PAULO 


\section{A PSICODINÂMICA DO PACIENTE CARDIOPATA: CONTRIBUIÇÕES DA PSICANÁLISE À CARDIOLOGIA}

(Versão original)

Tese apresentada ao Departamento de Psicologia Clínica (PSC) do Instituto de Psicologia da Universidade de São Paulo (IP - USP) como requisito para a obtenção do título de Doutor em Psicologia Clínica.

Área de Concentração: Psicologia Clínica Orientadora: Prof ${ }^{a}$. Dra. Livre Docente Elisa Maria Parahyba Campos Rodrigues 
AUTORIZO A REPRODUÇÃO E DIVULGAÇÃO TOTAL OU PARCIAL DESTE TRABALHO, POR QUALQUER MEIO CONVENCIONAL OU ELETRÔNICO, PARA FINS DE ESTUDO E PESQUISA, DESDE QUE CITADA A FONTE.

Catalogação na publicação

Biblioteca Dante Moreira Leite

Instituto de Psicologia da Universidade de São Paulo

Tamagnini, Elisabete Joyce Galhardo.

A Psicodinâmica do Paciente Cardiopata: Contribuições da Psicanálise à Cardiologia / Elisabete Joyce Galhardo Tamagnini; orientadora Elisa Maria Parahyba Campos Rodrigues. -- São Paulo, 2014.

$228 \mathrm{f}$.

Tese (Doutorado - Programa de Pós-Graduação em Psicologia. Área de Concentração: Psicologia Clínica) - Instituto de Psicologia da Universidade de São Paulo.

1. Psicanálise 2. Medicina psicossomática 3. Doenças cardiovasculares 4. Relações de objeto 5. Transplante de coração I. Título.

RC504 


\section{FOLHA DE APROVAÇÃO}

Nome: TAMAGNINI, Elisabete Joyce Galhardo

Título: A Psicodinâmica do Paciente Cardiopata: Contribuições da Psicanálise à Cardiologia.

Tese apresentada ao Departamento de Psicologia Clínica (PSC) do Instituto de Psicologia da Universidade de São Paulo (IP - USP) como requisito para a obtenção do título de Doutor em Psicologia Clínica.

Área de Concentração: Psicologia Clínica

Aprovada em:

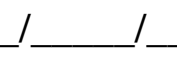

\section{BANCA EXAMINADORA}

Prof. Dr.

Instituição:

Assinatura:

Prof. Dr.

Instituição:

Assinatura:

Prof. Dr.

Instituição:

Assinatura:

Prof. Dr.

Instituição:

Assinatura:

Prof. Dr.

Instituição:

Assinatura: 
Ao Thiago, por entrar em meu caminho no início do doutoramento e ser aquele com quem, desde o princípio, desejei construir uma família... Por viver os meus objetivos como seus... e transformá-los em nossos! Por compartilharmos a melhor parte de nossas vidas... $A$ você, todo amor e gratidão...

Aos meus pais, Neide e Mário, pelos ensinamentos e valores transmitidos, pelo amor que sempre sustentou nossas relações... Sou grata por cada palavra de conforto e apoio... Por serem meus exemplos de luta e determinação, sem os quais esta conquista não seria possível. 


\section{AGRADECIMENTOS}

À Dra. Elisa Maria Parahyba Campos Rodrigues, minha orientadora que muito admiro. Agradeço pela confiança dispensada desde os tempos de Especialização em Psicoterapia Psicanalítica, pela proximidade e carinho que marcaram nosso vínculo até este momento, por todos os ensinamentos transmitidos.

Ao Dr. José Tolentino Rosa, por ter despertado em mim, ainda na Iniciação Científica, o desejo de trilhar este longo caminho. Agradeço por todos os anos de amizade e pelas supervisões e discussões teóricas que foram fundamentais para a realização deste trabalho.

À psicóloga Elaine Daniela Galhardo Tamagnini, irmã e amiga, por demonstrar seu interesse e preocupação ao longo desta e outras jornadas, por acompanhar e compreender cada momento deste processo, pelas tantas (longas) conversas e discussões que contribuíram significativamente para esta trajetória.

À Elisabete Joyce Maria Galhardo e Domingos Galhardo Lázaro, meus queridos avós, pela presença indispensável em minha vida, agradeço pela paz que transmitem, por serem o início de tudo.

Aos meus sogros, Margarete e João Carlos, e ao meu cunhado Danilo, por compreenderem algumas ausências durante este percurso e participarem ativamente de nossas vidas.

À Maria Lourenço dos Santos, minha gratidão pelos cuidados dispensados com amor e carinho ao longo de todos esses anos.

Ao Áron (in memorian), parceiro inseparável, por fazer minha vida muito mais feliz.

Aos familiares e amigos que colaboraram direta ou indiretamente para a realização deste trabalho, especialmente aos meus tios Henrique e Therezinha, e aos grandes (eternos) amigos Débora e Roberto... Muito obrigada pela presença essencial em minha vida.

Ao Dr. Adriano Meneghini, professor da Disciplina de Cardiologia da Faculdade de Medicina do $\mathrm{ABC}$ e colega pessoal, pelo apoio nos momentos difíceis, por partilhar de angústias similares e permitir efetivamente a execução desta pesquisa.

Ao Dr. Neif Murad, professor assistente da Disciplina de Cardiologia da Faculdade de Medicina do $\mathrm{ABC}$, por viabilizar prontamente a coleta dos dados, pelo carinho com que me recebeu e pelas palavras de incentivo que invadiam nossos encontros.

Ao Dr. José Alexandre da Silveira, coordenador do ambulatório de Insuficiência Cardíaca da Faculdade de Medicina do ABC, pela disponibilidade e apoio para a realização da avaliação psicodiagnóstica e por permitir o acompanhamento dos atendimentos ambulatoriais. 
Ao Dr. Antônio Carlos Palandri Chagas, professor titular e chefe da Disciplina de Cardiologia, da Faculdade de Medicina do ABC por incentivar e assentir a execução de meu projeto, confiando no trabalho que seria realizado.

Ao Dr. Nilton Gonçalves Júnior, chefe da Clínica Médica do Pronto Socorro Central de São Bernardo do Campo, SP, por fazer frente junto à direção do PS, garantindo autorização para os atendimentos aos pacientes cardiopatas na referida instituição.

À direção do Pronto Socorro Central de São Bernardo do Campo, por atender prontamente à solicitação de aval para a coleta de dados.

Ao Dr. Álvaro Avezum e ao Dr. Leopoldo Soares Piegas, pelos ensinamentos essenciais nas disciplinas ministradas no Instituto Dante Pazzanese de Cardiologia, que fortaleceram o meu desejo em seguir com este estudo.

Ao Dr. Avelino Luiz Rodrigues, psiquiatra e Prof. Doutor do Departamento de Psicologia Clínica, agradeço pela proximidade, carinho e interesse pela pesquisa, pelos ensinamentos que foram alicerces para o trabalho desenvolvido no HU e que contribuíram com as discussões nesta produção.

Aos alunos da Disciplina Psicologia da Saúde - Abordagem Bio-psico-social: Psicossomática, Hospitalar, Psico - Oncologia e colegas do Hospital Universitário, com quem tive o prazer de trabalhar.

Ao psicólogo Leandro Furlan, amigo de todas as horas, pela convivência ao longo dos anos e palavras de apoio, sobretudo por ser um grande amigo.

À Alessandra Marie Awad, grande amiga, por fazer parte de minha trajetória, pela cumplicidade e amor que nos mantém próximas ao longo de tantos anos.

À Dra. Maria Lívia Tourinho Moretto, por participar de minha banca de qualificação e contribuir significativamente para as idéias expostas aqui.

A Dra. Ivete Pellegrino Rosa, por acompanhar e incentivar o desenvolvimento deste e outros trabalhos, por sempre apresentar uma palavra de conforto nos momentos decisivos.

À Flávia, por todo o suporte dispensado ao longo dos dias, pela assistência especial e dedicação que fizeram diferença nos últimos anos.

À todos os pacientes que participaram deste estudo, meus sinceros agradecimentos.

À Coordenação de Aperfeiçoamento de Pessoal de Nível Superior (CAPES) pela concessão de apoio financeiro para a realização desta pesquisa. 
"Não nos surpreendemos com a raridade de uma espécie, mas ficamos chocados com o seu desaparecimento; é como admitir que a doença é o prelúdio da morte e não se sentir surpreso diante da doença, mas apenas com a morte da pessoa doente, não atribuindo o falecimento ao mal de que ela sofria, mas a algum ato desconhecido de violência."

Charles Darwin 
"As fantasias, como os sonhos, são realizações de desejos. Como os sonhos, baseiam-se, em grande medida, nas impressões de experiências infantis. Como os sonhos, beneficiam-se de certo grau de relaxamento da censura. Se examinarmos sua estrutura, perceberemos como o motivo de desejo que atua em sua produção mistura, rearranja e compõe, num novo todo, o material que eles são construídos. Eles estão para as lembranças infantis de que derivam, exatamente na mesma relação em que estão alguns palácios barrocos de Roma para as antigas ruinas, cujos pisos e colunas forneceram o material para as estruturas mais recentes."

Freud, S. “A Interpretação dos Sonhos” 


\section{RESUMO}

Tamagnini, E. J. G. (2014). A psicodinâmica do paciente cardiopata: contribuições da psicanálise à cardiologia. Tese de Doutorado em Psicologia Clínica, Instituto de Psicologia, Universidade de São Paulo, São Paulo.

Doenças cardiovasculares representam a principal causa de morte no mundo. É legítima a associação existente entre doenças cardiovasculares e eventos emocionais. Processos psíquicos podem ser desencadeados na DCV, provocando evolução desfavorável tanto dos sintomas afetivos quanto da doença clínica: promovem menor aderência às orientações terapêuticas e aumentam índices de morbi-mortalidade. Pacientes portadores de insuficiência cardíaca (IC) avançada, Classe Funcional (CF) III ou IV (NYHA) com sintomas graves, sem alternativa para tratamento clínico e com pior prognóstico são indicados ao transplante cardíaco (TC). A presente pesquisa teve como objetivo principal investigar a dinâmica psíquica envolvida nos diferentes estágios de DCV (especialmente de IC), identificando as particularidades psicodinâmicas encontradas em relação a pacientes que não apresentaram evidência da doença e avaliando a natureza das relações objetais e das fantasias inconscientes nas diferentes classes funcionais (NYHA). Método: estudo clínico, qualitativo, com delineamento observacional. Participantes: $\mathrm{N}=40$, subdivididos em grupos: A) DCV não evidente / B) CF I ou II / C) CF III ou IV não - indicados ao TC / D) CF III ou IV indicados ao TC. Instrumentos: 1 - entrevista clínica e Escala de Avaliação Global do Funcionamento AGF / DSM - IV; 2 - Teste de Relações Objetais de Phillipson - TRO. Lâminas: A1(1), B3(4), AG(5), BG(10), C2(11) e Branca(13). Procedimento: amostra por conveniência e aplicação dos instrumentos individualmente. A teoria psicanalítica das relações objetais de Melanie Klein orientou o desenvolvimento do estudo e serviu de base para a análise do material. Resultados: fantasias inconscientes e processos psíquicos arcaicos podem ser encontrados em todos os estágios da DCV, porém, os grupos mais avançados de DCV, apresentaram aspectos psicossomáticos expressivos, relações objetais e fantasias inconscientes provenientes das fases arcaicas do desenvolvimento, esquizoparanóide e viscocárica. No grupo $\mathrm{D}$, a frequência de relações de objeto da fase viscocárica foi mais expressiva, além de evidenciarem fantasias inconscientes específicas ligadas ao TC, como fantasias de mutilação. A avaliação psicanalítica foi fundamental para a compreensão da psicodinâmica do paciente cardiopata e identificou os FR psicossociais envolvidos no processo saúde - doença, sugerindo atenção especial da equipe multidisciplinar e instauração imediata de psicoterapia para determinados grupos. A intervenção psicanalítica visa redução dos sintomas e promoção de saúde mental / psíquica: preserva o autocuidado, estimula o cumprimento das orientações de equipe e de protocolo, reforça a adesão ao tratamento. $\mathrm{O}$ controle dos FR observados pode determinar um prognóstico favorável quando considerado no tratamento dos pacientes cardiopatas.

Palavras-Chave: psicanálise; medicina psicossomática; doenças cardiovasculares; relações de objeto; transplante de coração. 


\begin{abstract}
Tamagnini, E. J. G. (2014). Psychodynamic of cardiac patient: psychoanalysis contributions to cardiology. Thesis - Degree of Doctor for Clinical Psychology, Instituto de Psicologia, Universidade de São Paulo, São Paulo.
\end{abstract}

Cardiovascular diseases are the leading cause death worldwide. There is a clear association between cardiovascular disease and emotional events. Psychic processes can happen in CVD, causing unfavorable evolution of affective symptoms and clinical disease: resulting in lower adherence to medical guidelines and higher rates of morbidity and mortality. Patients with advanced heart failure (HF), in NYHA functional class III or IV with severe symptoms, no alternative to clinical treatment and a worse prognosis are listed for heart transplantation (HT). The main objective was investigate the psychodynamics at different stages of CVD (mainly in HF), identifying the psychodynamic characteristics found in relation to patients without evidence of disease and assessing the nature of object relations and unconscious fantasies in different functional classes (NYHA). Method: Clinical, qualitative and observational study design. Participants: $N=40$, in groups: A) patients without cardiovascular disease / B) functional class I or II / C) functional class III or IV not listed for HT / functional class III or IV with indications for HT. Instruments: 1 - clinical interview and assessment of global functioning / GAF - DSM - IV, 2 - Object Relations Test (ORT) by Phillipson A1(1), B3(4), AG(5), BG(10), C2(11), White (13). Procedure: convenience sample and individual application. The object relations theory of Melanie Klein guided the development of the study and analysis of the material. Results: unconscious fantasies and psychic processes archaic can be found in all stages of CVD, however, the most advanced CVD groups showed significant psychosomatic aspects, object relations and unconscious fantasies from very archaic development phases. In group $\mathrm{D}$, the frequency of object relations of viscumcarica position was more expressive and showed specific unconscious fantasies in relation to HT, as the fantasies of mutilation. The psychoanalytic review was essential to understanding the cardiac patients psychodynamics and identified psychosocial risk factors (RF) involved in the health - disease process, suggesting special attention of the multidisciplinary team and immediate psychotherapy for some groups. Psychoanalytic intervention reduces symptoms and promotes mental health: improves self-care, execution of team guidelines and protocol and treatment adherence. The control some risk factors can determine a favorable prognosis when considered in the treatment of cardiac patients.

Keywords: psychoanalysis; psychosomatic medicine; cardiovascular disease; object relations; heart transplantation. 


\title{
SUMÁRIO
}

\author{
AGRADECIMENTOS \\ EPÍGRAFE(S) \\ RESUMO \\ ABSTRACT \\ SUMÁRIO \\ LISTA DE ANEXOS \\ LISTA DE APÊNDICES \\ LISTA DE QUADROS \\ LISTA DE TABELAS \\ LISTA DE SIGLAS
}

1. INTRODUCÃ̃O

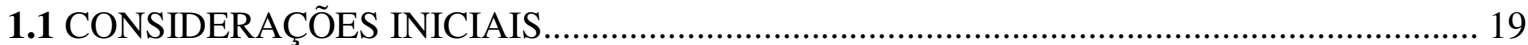

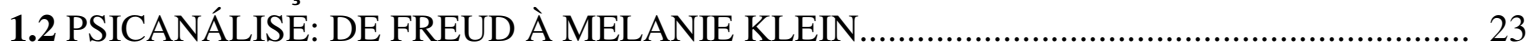

1.2.1 A TEORIA PSICANALÍTICA DAS RELAÇÕES OBJETAIS …................................ 23

1.2.2 FANTASIAS INCONSCIENTES: MAIS QUE UM CONCEITO................................. 32

1.2.3 PSICANÁLISE E PSICOSSOMÁTICA: UMA IMPORTANTE ARTICULAÇÃO........ 33

1.3 A DOENÇA CARDIOVASCULAR E O PACIENTE CARDIOPATA........................................4

1.3.1 INSUFICIÊNCIA CARDÍACA (IC) E CLASSE FUNCIONAL(CF) NYHA PARA IC.44

1.3.2 TRANSPLANTE CARDÍACO (TC) E O PACIENTE CARDIOPATA GRAVE........... 45

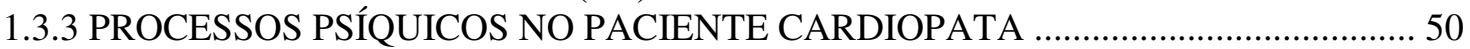

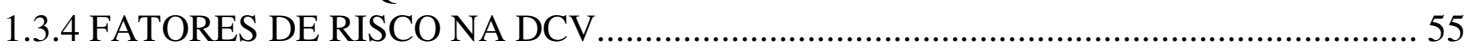

2. DELINEAMENTO DO ESTUDO / PESQUISA

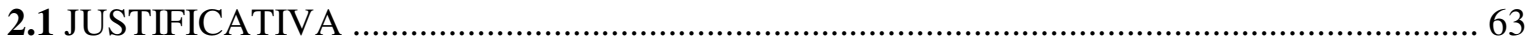

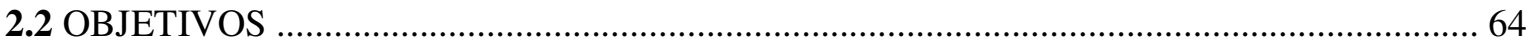

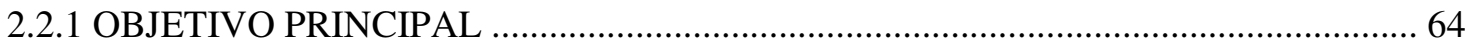

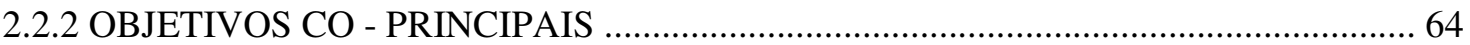

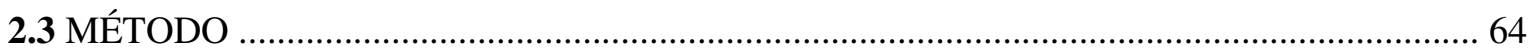

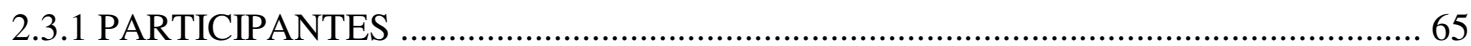

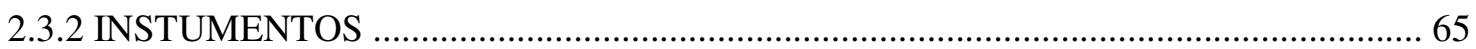

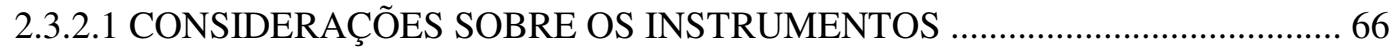

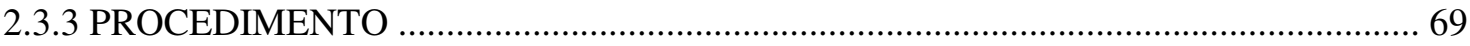

3. RESULTADOS

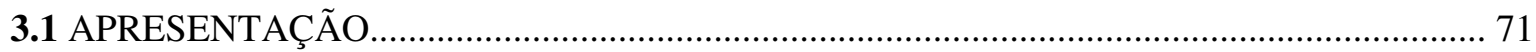

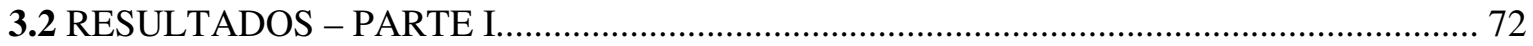

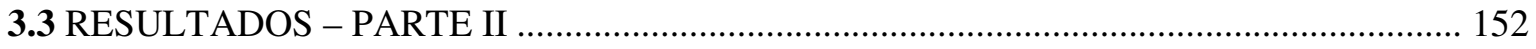

4. DISCUSSÃO

5. CONCLUSÕES 204

6. REFERÊNCIAS 


\section{LISTA DE ANEXOS}

ANEXO A - Escala de Avaliação Global do Funcionamento do DSM IV - AGF. 222 


\section{LISTA DE APÊNDICES}

APÊNDICE A - Protocolo de Análise e Interpretação do Teste de Relações Objetais de Phillipson (TRO)

APÊNDICE B - Termo de Consentimento Livre e Esclarecido (TCLE) 


\section{LISTA DE QUADROS}

Quadro 1. Avaliação das lâminas - paciente 1 do grupo A ...................................................72

Quadro 2. Avaliação das lâminas - paciente 2 do grupo A …............................................ 74

Quadro 3. Avaliação das lâminas - paciente 3 do grupo A ….............................................. 76

Quadro 4. Avaliação das lâminas - paciente 4 do grupo A …….......................................... 78

Quadro 5. Avaliação das lâminas - paciente 5 do grupo A ……......................................... 80

Quadro 6. Avaliação das lâminas - paciente 6 do grupo A …............................................ 82

Quadro 7. Avaliação das lâminas - paciente 7 do grupo A .................................................. 84

Quadro 8. Avaliação das lâminas - paciente 8 do grupo A …............................................... 86

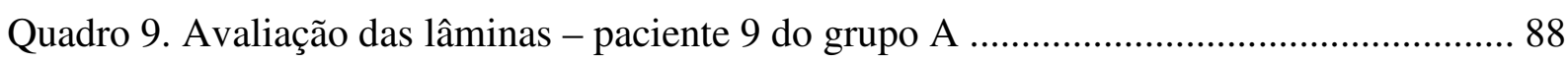

Quadro 10. Avaliação das lâminas - paciente 10 do grupo A ............................................... 90

Quadro 11. Avaliação das lâminas - paciente 1 do grupo B ................................................ 92

Quadro 12. Avaliação das lâminas - paciente 2 do grupo B ................................................ 94

Quadro 13. Avaliação das lâminas - paciente 3 do grupo B ……………............................ 96

Quadro 14. Avaliação das lâminas - paciente 4 do grupo B ................................................. 98

Quadro 15. Avaliação das lâminas - paciente 5 do grupo B ………….............................. 100

Quadro 16. Avaliação das lâminas - paciente 6 do grupo B …......................................... 102

Quadro 17. Avaliação das lâminas - paciente 7 do grupo B ............................................... 104

Quadro 18. Avaliação das lâminas - paciente 8 do grupo B ……..................................... 106

Quadro 19. Avaliação das lâminas - paciente 9 do grupo B .............................................. 108

Quadro 20. Avaliação das lâminas - paciente 10 do grupo B ………................................. 110

Quadro 21. Avaliação das lâminas - paciente 1 do grupo C ............................................. 112

Quadro 22. Avaliação das lâminas - paciente 2 do grupo C .............................................. 114

Quadro 23. Avaliação das lâminas - paciente 3 do grupo C .............................................. 116

Quadro 24. Avaliação das lâminas - paciente 4 do grupo C .............................................. 118 
Quadro 25. Avaliação das lâminas - paciente 5 do grupo C

Quadro 26. Avaliação das lâminas - paciente 6 do grupo C 122

Quadro 27. Avaliação das lâminas - paciente 7 do grupo C 124

Quadro 28. Avaliação das lâminas - paciente 8 do grupo C 126

Quadro 29. Avaliação das lâminas - paciente 9 do grupo C 128

Quadro 30. Avaliação das lâminas - paciente 10 do grupo C 130

Quadro 31. Avaliação das lâminas - paciente 11 do grupo C 132

Quadro 32. Avaliação das lâminas - paciente 12 do grupo C 134

Quadro 33. Avaliação das lâminas - paciente 13 do grupo C 136

Quadro 34. Avaliação das lâminas - paciente 1 do grupo D 138

Quadro 35. Avaliação das lâminas - paciente 2 do grupo D 140

Quadro 36. Avaliação das lâminas - paciente 3 do grupo D 142

Quadro 37. Avaliação das lâminas - paciente 4 do grupo D 144

Quadro 38. Avaliação das lâminas - paciente 5 do grupo D 146

Quadro 39. Avaliação das lâminas - paciente 6 do grupo D 148

Quadro 40. Avaliação das lâminas - paciente 7 do grupo D 150 


\section{LISTA DE TABELAS}

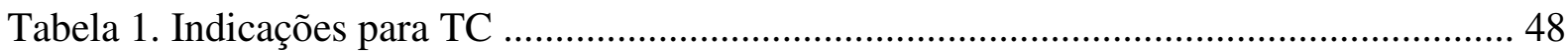

Tabela 2. Contraindicações absolutas para TC …................................................................ 49

Tabela 3. Critérios de Avaliação Psicológica do Candidato ao TC ....................................... 56

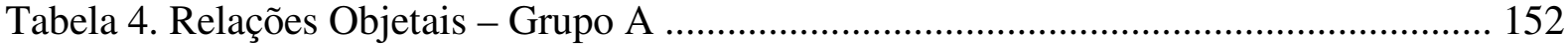

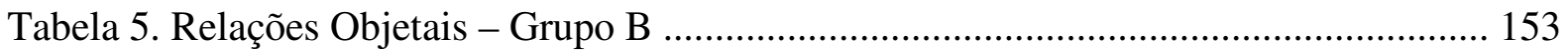

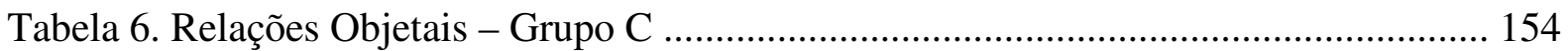

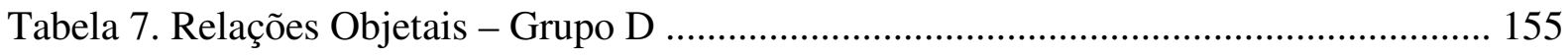

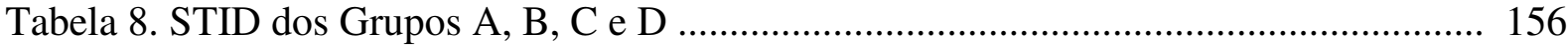




\section{LISTA DE SIGLAS}

$A G F$

Avaliação Global do Funcionamento

ANVISA Agência Nacional de Vigilância Sanitária

AVC Acidente Vascular Cerebral

AVCi Acidente Vascular Cerebral Isquêmico

BB Betabloqueador

BCP Broncopneumonia

CCC Cardiopatia Chagásica Crônica

CF Classe Funcional

CMD Cardiomiopatia Dilatada

COCPIT Comparative Outcome and Clinical Profiles in Transplantation

CR Cardite Reumática

CVD Cardiovascular Disease

DAC Doença Arterial Coronariana

DCP Doença Cardiopulmonar

DCV Doença Cardiovascular

DM Diabetes Mellitus

DPOC Doença Pulmonar Obstrutiva Crônica

DSM - IV Diagnostic and Statistical Manual - Manual Diagnóstico e Estatístico de Transtornos Mentais

DVP Doença Vascular Periférica

$\mathrm{FI} \quad$ Fantasia Inconsciente

FMABC Faculdade de Medicina do ABC

FR Fator de Risco

GAF Global Assessment of Functioning

HAS Hipertensão Arterial

HDL High Density Lipoproteins

HF Heart Failure

HFSS Heart Failure Survival Score

HT Heart Transplantation

IAM Infarto Agudo do Miocárdio

IC Insuficiência Cardíaca 


\begin{tabular}{ll} 
ICC & Insuficiência Cardíaca Crônica \\
ICO & Insuficiência Coronariana \\
IDPC & Instituto Dante Pazzanese de Cardiologia \\
IRA & Insuficiência Renal Aguda \\
ITU & Infecção do Trato Uterino \\
LDL & Low Density Lipoproteins \\
MCP & Miocardiopatia \\
MID & Membro Inferior Direito \\
NYHA & New York Heart Association \\
OMS & Organização Mundial da Saúde \\
ORT & Object Relations Test \\
QT & Quimioterapia \\
RF & Risk Factor \\
RVP & Resistência Vascular Pulmonar \\
SCA & Síndrome Coronariana Aguda \\
SST & Supradesnivelamento de Seguimento ST \\
STID & Sistema Tensional Inconsciente Dominante \\
TC & Transplante Cardíaco \\
TCLE & Termo de Consentimento Livre e Esclarecido \\
TCP & Teste Cardiopulmonar \\
TEPT & Transtorno de Estresse Pós - Traumático \\
TRO & Teste de Relações Objetais \\
UTI & Unidade de Terapia Intensiva \\
VC & Volume Corrente \\
VE & Volume de Ejeção \\
VO & Volume de Oxigênio \\
\hline
\end{tabular}




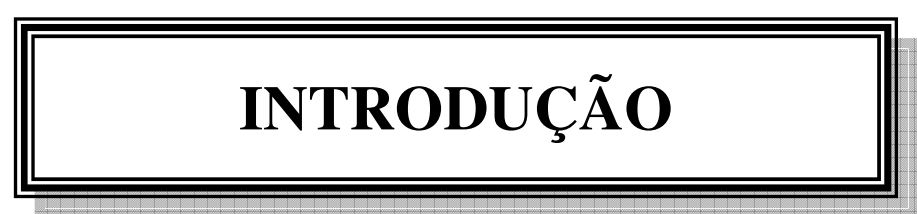




\subsection{CONSIDERAÇÕES INICIAIS}

"A ciência é, afinal, a renúncia mais completa ao princípio do prazer de que é capaz nossa atividade mental."

Freud, $S$.

\section{- Da Iniciação Científica ao Doutorado...uma Jornada...}

Falar sobre o nascimento e desenvolvimento desta pesquisa só é possível a partir do conhecimento e compreensão de seus desdobramentos. Retrata uma longa jornada que levou aos questionamentos referentes à prática clínica e seus alcances, resultando no delineamento do estudo atual.

Em 2002, durante a Graduação em Psicologia, fui apresentada ao Prof. Dr. José Tolentino Rosa, com quem trabalho até o momento, meu orientador no período de Iniciação Científica. Desenvolvemos uma pesquisa sobre a representatividade dos sonhos e processos oníricos em estudantes universitários. A partir de então, a Psicanálise, particularmente a teoria psicanalítica de Melanie Klein, foi base para os trabalhos seguintes. Em 2004, iniciei o curso de Especialização em Psicoterapia Psicanalítica na Universidade de São Paulo, coordenado pelo Prof. Dr. Ryad Simon. Além do imenso prazer em ser aluna do Prof. Ryad ao longo dos três anos de curso, tive a satisfação de ser supervisionada pela Prof ${ }^{\mathrm{a}}$. Dra. Elisa Maria Parahyba Campos Rodrigues, Livre Docente pelo Instituto de Psicologia da Universidade de São Paulo. Durante as supervisões de casos clínicos, uma valiosa relação foi construída. A construção e manutenção destes importantes vínculos foram fundamentais e influenciaram nas escolhas que perpassaram o caminho percorrido na Pós - Graduação em Psicologia Clínica na Universidade de São Paulo. 
O tema de pesquisa para a inserção no mestrado, motivado pela sugestão do Dr. José Tolentino em darmos continuidade à linha de pesquisa na qual trabalhava na época, parecia definido antes mesmo de pensar que seria escolhido, tal a identificação que permeou sua eleição. O trabalho sobre os processos psíquicos em cardiopatas graves originou a dissertação: “Transplante Cardíaco: Sistema Tensional Inconsciente Dominante e Diagnóstico Adaptativo Operacionalizado de Mulheres Candidatas ao Enxerto”.

O contato com os pacientes candidatos ao transplante cardíaco abriu caminho para reflexões sobre o momento crucial vivido no período de espera e os processos psíquicos decorrentes da indicação à cirurgia. As questões emocionais envolvidas não pareciam vinculadas apenas à espera pelo coração, mas à cardiopatia, ao significado do adoecimento cardíaco. Assim, é evidenciada a idéia para um novo tema de pesquisa no doutorado, como continuidade ao trabalho anterior.

O problema a ser investigado foi claramente definido durante a disciplina "Pesquisa em Medicina Cardiovascular: Planejamento, Execução e Avaliação”, ministrada pelo Dr. Álvaro Avezum, no Instituto Dante Pazzanese de Cardiologia. No decorrer dos estudos, indagou aos participantes: "Por que as pessoas adoecem?”, sugerindo a apresentação de seminários que discutissem razões para o adoecimento que iriam além do argumento médico. Esta indagação culminou com a apresentação do trabalho intitulado "Por que adoecemos? Análise crítica acerca dos instintos de vida e morte em: Alice in Wonderland" e, naquele momento, foram considerados os processos psicodinâmicos envolvidos na relação do doente com a doença e que atuam como importantes fatores de risco. Percebi, então, como esta é uma área de interesse não apenas dos profissionais “psi”... Cada profissional médico, maioria no grupo, pensou em razões diversas que podem levar ao adoecimento do corpo. Demonstraram, assim, que há um movimento na direção de estimular este pensamento entre os profissionais: 
considerar o paciente como produto de uma história e inserido em um contexto, compreender a unidade mente - corpo, entender o paciente intrinsecamente vinculado à doença.

Definida a questão principal do estudo, o projeto começa a encontrar os primeiros obstáculos para sua execução: questões de ordem desconhecida (poderia dizer política ou burocrática, mas nada mais são do que desconhecidas), inviabilizaram a proposta inicial, implicando em importantes modificações estruturais e originando o delineamento de uma nova proposta. Diante desta situação aparentemente desfavorável, o momento de qualificação aparece como decisivo: fez pensar no estudo como base para a formulação de um protocolo de atendimento em cardiologia, de fundamentação psicanalítica, com aplicabilidade em ambientes como o hospitalar, em pacientes de diferentes estágios da doença cardiovascular.

Pensar em quais seriam as razões implícitas que inviabilizam a execução de um estudo não é tarefa simples. Não estaria, nesta execução, o caminho que direciona ao desenvolvimento científico e acadêmico dos envolvidos? São inúmeros os desdobramentos de uma pesquisa e, a reformulação do delineamento do estudo, derivada das adversidades encontradas, possibilitou a ampliação de seus objetivos. O paciente é, sem dúvida, o principal prejudicado nos serviços que impossibilitam pesquisadores de colocar seus estudos em prática, já que uma pesquisa não pressupõe mera coleta de dados, mas contribuição efetiva junto aos setores de interesse.

O enfrentamento dos diversos fatores que envolvem o progresso de um estudo está intrinsecamente associado ao prazer / satisfação presentes neste processo. Em função de minha formação em Psicoterapia Psicanalítica, acredito que fantasias inconscientes perpassem o gerenciamento destes fatores e auxiliam na manutenção de nossas escolhas. Freud (1996c) diz que o princípio do prazer está estreitamente vinculado ao princípio de constância e atua para liberar o aparelho mental da excitação, ou manter seu nível constante ou tão baixo quanto 
possível. Acredito que sejam estas as principais razões que nos motivam a prosseguir e a concluir um trabalho acadêmico, mesmo que, para isso, as adversidades se interponham como partes indissociadas do processo.

O trabalho acadêmico requer, principalmente, uma capacidade de tolerância à frustração diante dos inúmeros obstáculos que se apresentam ao longo de sua execução. Aqueles que estão engajados nesta tarefa, por diferentes motivos, são unânimes diante desta afirmação. Encaramos diversos impasses, inerentes ou não à pesquisa, que invariavelmente/inevitavelmente nos levam ao questionamento sobre as razões e emoções implicadas neste complexo processo, um desenvolvimento que considero não apenas científico e profissional, mas principalmente, pessoal. 


\subsection{PSICANÁLISE: DE FREUD À MELANIE KLEIN}

"O homem chega à sua maturidade quando encara a vida com a mesma seriedade que uma criança encara uma brincadeira."

Nietzsche, F. W.

\subsubsection{A Teoria Psicanalítica das Relações Objetais}

Melanie Klein apresentou seu primeiro artigo em 1919 para a Sociedade Psicanalítica Húngara, revolucionando a teoria e a prática psicanalíticas, marcando o início de uma produção criativa que continuou até a sua morte, em 1960. Desenvolveu um método para a análise de crianças, considerando que expressavam o mundo interior simbolicamente através dos jogos, e comparou este meio de expressão com a associação livre feita por adultos, em análise. Identificou que as crianças são capazes de estabelecer rapidamente relações transferenciais, com projeções de imagens internas. O trabalho direto com crianças trouxe novas descobertas, como a riqueza do mundo interior repleto de figuras tanto boas como más, além de muitas aterrorizantes que geravam intensa ansiedade, com caráter psicótico.

A técnica lúdica na análise de crianças desde tenra idade forneceu instrumentos para desvendar segredos das profundezas da mente humana, desde os primórdios de sua formação. Não é possível entender os conteúdos e o funcionamento da mente psicótica sem os conceitos que desenvolveu no estudo da comunicação infantil.

As contribuições para a teoria e técnica psicanalítica podem ser divididas em fases: quando fundamentou a análise de crianças e considerou as raízes primitivas do complexo de Édipo e do superego (Klein, 1948; 1997b); com a formulação do conceito de posição 
depressiva e dos mecanismos de defesa maníaca (Klein, 1996a; 1996b) e no momento em que se ocupou da posição esquizoparanóide (Klein, 1991b; 1991c).

A técnica kleiniana se fundamenta rigorosamente nos conceitos psicanalíticos freudianos. Observa que crianças desenvolvem transferência positiva e negativa com rapidez e intensidade. O Complexo de Édipo e o superego se evidenciam mais cedo e é perturbadora a força dos mecanismos de projeção e introjeção. Fantasias inconscientes, para Klein, surgem diretamente dos instintos, da polaridade dos mesmos e dos conflitos entre eles. Estas fantasias se alteram mediante o contato com a realidade.

Há importante conexão entre a fantasia e a estrutura mental: mecanismos de projeção e introjeção, por exemplo, são fundamentais nas fantasias primitivas de incorporação e expulsão (Segal, 1982).

Concebe o Complexo de Édipo como consequência da frustração pelo desmame e com a noção da diferença existente entre os sexos, ocorrendo entre o final do primeiro ano e início do segundo ano de vida da criança. Desde o início, os desejos edipianos estão associados ao medo da castração e formação da culpa. A ansiedade no início do conflito edipiano é originada pelo medo da destruição, uma vez que a própria criança deseja destruir o objeto libidinal: a ansiedade existe porque o despertar das tendências edipianas é seguido pela introjeção do objeto total, do qual agora, se espera punição.

Não é possível estabelecer distinção nítida entre os estágios iniciais do conflito edipiano e os estágios posteriores, tal a fusão de impulsos pré-genitais e genitais, manifestada ao longo dos estágios (Klein, 1997a).

Freud afirmou que os sintomas da neurose eram uma defesa contra a neurose de ansiedade, produzida por ameaças contra o paciente, originadas de seu superego: não era a repressão que produzia ansiedade ao obstruir a libido, e sim a ansiedade que produzia repressão sendo então, a neurose, o resultado de um superego hostil (Freud, 1996d). Foram os 
estudos de Klein que indicaram a presença de um superego anterior à fase edípica, infinitamente mais severo e cruel do que o de uma criança mais velha ou de um adulto (Caper, 1990)

O conceito de instinto, em Freud, passa por duas definições. Inicialmente, é concebido como situado entre o mental e o somático, o representante psíquico dos estímulos que atingem a mente e são originados no organismo. Posteriormente, considera o instinto como o conceito presente na fronteira entre o somático e o mental, como o representante psíquico de forças orgânicas (Freud, 1996c; Strachey, 1996). A idéia que representa o instinto, na teoria psicanalítica kleiniana, são as fantasias originais: a compreensão da natureza e da função da fantasia na vida mental deve envolver o estudo das fases iniciais do desenvolvimento. Aquelas que se manifestaram em situações anteriores da vida, serão repetidas e representadas no mundo adulto (Isaacs, 1952).

As posições definidas por Klein são caracterizadas por desejos inconscientes, medos / ansiedades e mecanismos de defesa:

A) Posição Depressiva:

- Desejos Inconscientes: reparar / restaurar o objeto estragado, diminuir clivagem / fragmentação, objeto total.

- Medos / Ansiedades: angústia depressiva, culpa, luto (destruição do objeto).

- Mecanismos de Defesa: reparação maníaca, controle onipotente, triunfo, introjeção do bom objeto.

B) Posição Esquizoparanóide:

- Desejos Inconscientes: proteger do aniquilamento, separar objeto bom e mau.

- Medos / Ansiedades: angústia / persecutoriedade, solidão, medo do aniquilamento, inveja do bom, medo de progredir, autodesvalorização, ambivalência, voracidade. 
- Mecanismos de Defesa: negação / escotomização, identificação projetiva, excisão, idealização, escotomização, paralisação, controle de objetos.

C) Posição Viscocárica (Rosa, 2005) / Gliscrocárica (Bleger, 1988):

- Desejos Inconscientes: fusão com o objeto, simbiose, dependência, paralisar o objeto ou o self, destruir.

- Medos / Ansiedades: angústia confusional, hipocondria, perplexidade, perseguição de fragmentos, ausência de sentido, vertigem / enjôo.

- Mecanismos de Defesa: identificação adesiva, clivagem / cisão, imobilização, fragmentação, confusão, desaparecimento do self, hostilidade.

Primeiramente, descreve a relação da criança com objetos parciais (inicialmente o seio cindido da mãe, o bom e mau), estendendo-se para o corpo inteiro da mãe, o que gera os primeiros impulsos epistemofílicos. Estes impulsos voltados para o corpo da mãe geram ansiedades, deslocando o interesse da criança para o mundo exterior e atribuindo a eles um significado simbólico. Melanie Klein enfatizava o papel da agressividade nas crianças, acordando com os conceitos de pulsão de vida e morte de Freud, admitindo os conflitos básicos como aqueles que ocorrem entre as forças libidinais e destrutivas, entre o amor e o ódio. A fantasia inconsciente está, em sua teoria, imbricada ao simbolismo, e se expressa simbolicamente. Diverge de Freud ao afirmar que o símbolo é criado dinamicamente a partir da ansiedade estando, assim, sujeito à malformação e inibição (Segal, 1996).

As relações de objeto da criança se prolongam pelo passado, até uma relação de objetos parciais (seio e pênis), precedendo a relação com os pais como objetos totais. Estas primitivas relações de objeto são caracterizadas pela relação entre as fantasias inconscientes e a experiência real. O papel desempenhado pela fantasia inconsciente, bem como sua expressão simbólica, leva à reformulação de seu conceito: a natureza das fantasias e o modo 
como se relacionam com a realidade externa determinam o mundo psicológico do indivíduo (Segal, 1975).

Os pais são os primeiros objetos das projeções da criança. As projeções de impulsos destrutivos são freqüentes na infância porque estão relacionadas à preservação da vida. Da mesma maneira, são vivenciados impulsos de ódio e destruição como ameaças / perigos à própria existência (Caper, 1990).

O equipamento que crianças dispõem para projeções consiste na capacidade pulsional que possibilita os mecanismos de projeção e introjeção.

Quando levados para dentro por meio da introjeção, os pais externos dão origem ao superego primitivo e severo da infância (Klein, 1997a).

Estas posições continuam presentes pelo resto da vida, alternando-se em função do contexto, embora a posição depressiva predomine num desenvolvimento saudável (Simon, 1986).

É possível compreender o explicitado como uma constelação dinâmica da personalidade que envolve as características das relações objetais. Estas constelações são entendidas como manifestações de fantasias inconscientes que ocorrem através de desejos inconscientes, medos e sentimentos de angústia, de perseguição, confusão, depressão e mecanismos de defesa (Rosa, 2005).

Na primeira infância, surgem ansiedades que são características das psicoses, que obrigam o ego a desenvolver específicos mecanismos de defesa, período em que se encontram os pontos de fixação dos distúrbios psicóticos. As ansiedades e os mecanismos de defesa influenciam a formação do ego, do superego e das relações de objeto, ou seja, todos os aspectos do desenvolvimento (Klein, 1991b). 
O superego destrutivo que anteriormente se julgava estar presente apenas em doentes gravemente neuróticos, estava presente em fases iniciais do desenvolvimento de qualquer pessoa, o que sugere que bebês sofrem um tipo de ansiedade psicótica (Caper, 1990).

O prazer do bebê em morder não se deve apenas à satisfação libidinal das zonas erógenas, está ligada a desejos destrutivos que visam ao aniquilamento do objeto, o que é mais marcante na fase de auge do sadismo, quando o bebê tem diversos métodos à disposição das suas tendências sádicas, como dentes e unhas (Abrahan, 1924).

As ansiedades persecutórias estariam relacionadas às figuras internas más e, quando a criança deixa de se relacionar com partes da mãe e compreende a pessoa inteira, percebe que a figura má e boa são a mesma pessoa, sofrendo de culpa devido à agressividade que fora empregada contra a pessoa amada. O conceito de posição depressiva é formulado pois contempla o momento em que a criança sente culpa e medo da perda, provenientes dos ataques lançados ao objeto de amor.

Estes sentimentos substituem gradualmente a persecutoriedade anterior e despertam tendências amorosas e de reparação pelo dano causado (Segal, 1996).

Freud formulou o conceito de estrutura mental em termos de id, ego e superego, esclarecendo que as partes do self não estão separadas e que o id é alicerce do funcionamento mental.

Afirma, então, que não há no inconsciente o medo da morte, o que não parecia compatível com sua teoria sobre o trabalho interno da pulsão de morte. O perigo de ser destruído por esta pulsão cria uma extensão sentida no ego como ansiedade que precisa ser enfrentada. O medo da morte seria, então, a mais fundamental de todas as angústias (Klein, 1991d).

Em sua última forma, o superego - objeto interno - se faz conhecer pelo sentimento de culpa, sendo que, o superego rudimentar (monstruoso, destrutivo e cruel) não se baseava 
apenas na experiência da criança com o comportamento real dos pais. Assim, as fantasias inconscientes, expressando impulsos de amor e ódio, entram e modificam a experiência do bebê com os pais (Klein, 1997a).

Freud descobriu que a criança continuava no adulto, Melanie Klein descobriu o bebê presente na criança e no adulto (Segal, 1996).

A partir da formulação do conceito de posições em 1934, Melanie Klein modificou significativamente seu ponto de vista teórico: as posições não eram contrárias aos conceitos de id, ego e superego. Postula como objetivo principal o de definir a estrutura real do superego e do ego e demonstrar o caráter de seus relacionamentos nos termos das posições esquizoparanóide e depressiva.

Os fenômenos da posição depressiva permitem a compreensão da natureza do luto: a perda do objeto bom externo remete à sensação inconsciente de perda de um objeto bom interno. Há importante relação entre o teste de realidade no luto normal e os processos arcaicos da mente. Ansiedades arcaicas de caráter persecutório e depressivo são despertadas.

A criança passa por estados mentais comparáveis ao processo de luto do adulto e, o luto arcaico, é revivido em a cada situação de pesar da vida adulta (Klein, 1996b).

O instinto de morte (sadismo) é predominante na experiência do nascer, além de existir uma relação de objeto (seio) desde o início. Nos primeiros momentos da vida, em plena angústia derivada do instinto de morte, as primeiras formas de funcionamento mental serão as fantasias inconscientes; o bebê sente a possibilidade de se aliviar da angústia de aniquilamento, depositando o que é ruim neste objeto que se torna mau (persecutório, que quer atacar o bebê, o que frustra e não acalma).

As defesas, nesta fase, são a projeção e introjeção. Posteriormente, o objeto pode ser percebido como único, total, e é originada a culpa por ter atacado, inicialmente, um objeto mau que também era bom. Neste momento, alteram-se as defesas e a angústia não é mais 
persecutória (medo do aniquilamento do ego), e sim depressiva, caracterizada pelo medo da perda do objeto amado (Klein, 1991a).

Melanie Klein se utiliza das concepções de Freud, mas estrutura o trabalho de luto a partir de suas concepções teóricas. Verifica que crianças enfrentam um estado de luto como o adulto e que, este "luto arcaico", é revivido em cada situação posterior de pesar. O mundo externo à criança (o seio materno e tudo o que passa a representar na mente do bebê) se relaciona às fantasias inconscientes e dão origem ao seu mundo interno.

Diante da perda, as defesas das fases esquizoparanóide e depressiva são reativadas: revive-se a situação de luto anterior que irá determinar como o adulto lidará com a nova situação apresentada. $\mathrm{O}$ aumento de amor e confiança, acompanhado pela redução do medo através de experiências felizes, ajudam o bebê a vencer gradualmente sua depressão e sentimento de perda (luto), permitindo que teste sua realidade interna através da realidade externa (Klein, 1997b).

Os sentimentos de luto e culpa, implicam em progressos vitais na vida emocional e intelectual do bebê e vão depender da síntese entre os aspectos amados e odiados do objeto completo, total. Este constitui um ponto crucial para a escolha da neurose ou psicose (Da Silva, Rosa, Paegle, \& Braunholz, 2004).

A base da saúde mental é a manutenção de uma personalidade integrada, capaz de desenvolver maturidade emocional, lidar com emoções conflitantes, manter o equilíbrio entre a vida interna e se adaptar à externa, conquistando uma bem sucedida fusão das diferentes partes em um todo.

Na situação analítica, as relações objetais e a natureza das fantasias inconscientes são consideradas para a compreensão dos processos psíquicos envolvidos no sofrimento, sendo a transferência recurso fundamental para esta apropriação. 
Freud designa transferência como um importante instrumento do trabalho analítico, que permite ao paciente reviver o passado sob novas condições e retificar decisões e destinos patológicos. A contratransferência seria o instrumento utilizado para compreender os mecanismos específicos instaurados na situação psicológica apresentada (Racker, 1960).

Não é suficiente considerar a transferência apenas como mecanismo de deslocamento de impulsos libidinosos, manifestação de repetição compulsiva ou conflitos não resolvidos. Nas repetições e deslocamentos, as fantasias inconscientes são operativas (Heimann, 1977).

A compreensão da expressão simbólica dos conflitos inconscientes na análise de crianças, na teoria psicanalítica de Melanie Klein, torna-se importante via de acesso para o inconsciente: ao identificar aspectos transferenciais e ansiosos, como na análise de adultos, podemos descobrir um rico mundo de fantasias inconscientes e relações de objeto (Segal, 1975).

A perversão de transferência seria um tipo especial de transferência. A loucura pressupõe redescobrir o mundo em sua infinita variedade de riqueza e como um erro dos sentidos. Assim, a realidade é enlouquecedora para quem vive em um mundo de alucinações negativas (negação da realidade). A perversão não é, portanto, uma defesa contra a psicose: é a própria psicose (Etchegoyen, 1987).

A apreensão do sentido da comunicação do paciente é possível através da percepção empática intuitiva, uma forma de penetração psíquica no mundo mental que favorece a impressões emocionais do outro, de como vive no momento.

$\mathrm{O}$ analista depende de certa identificação projetiva (imaginação) para atingir este objetivo, alcançado principalmente com um nível significativo de atenção flutuante. A contratransferência seria, portanto, uma perturbação do estado de atenção flutuante (Simon, 1991). 


\subsubsection{Fantasias Inconscientes: Mais Que Um Conceito}

É a partir do abandono da gênese da neurose na sedução traumática, que a fantasia adquire um valor de maior destaque para a teoria psicanalítica. Freud conclui que o conflito patógeno pode ser desencadeado a partir de uma fantasia inconsciente e, como consequência, trilhar um percurso no aparelho psíquico em direção ao sintoma neurótico.

Nos Estudos Sobre a Histeria a Psicanálise assentou seus objetivos: decifrar sintomas, compreender a dinâmica mental e organizar ações transformadoras da vida psíquica. A interação da realidade interna e externa é entendida quando o homem percebe esta realidade a partir da interação entre sensações e fantasias (Freud, 1996a).

As fantasias revelaram-se a Freud como ficções destinadas a encobrir a sexualidade infantil, mas nem por isso podem ser ditas simplesmente falsidades, já que têm efeitos inegáveis quanto à formação dos sintomas e, em geral, na vida mental dos pacientes (Freud, 1996e).

A inter - relação entre fantasia inconsciente e realidade externa mostra a importância do ambiente no desenvolvimento da criança. Além da expressão mental dos instintos, as fantasias têm uma importante função defensiva. A gratificação derivada da fantasia é uma defesa contra uma realidade externa de privação, mas também é uma defesa contra a realidade interna, como sintomas de fome e raiva (Oliveira \& Luz, 1992).

A fantasia inconsciente está sempre influenciando e alterando a percepção da realidade e o contrário também é verdadeiro: a realidade exerce impacto sobre elas. Pode ser considerada representante psíquico ou expressão mental dos instintos.

O termo fantasia (phantasy) estabelece uma relação com o substrato mental inconsciente, sendo o conteúdo primário dos processos inconscientes (Isaacs, 1952). 
Esta é uma característica especial da técnica psicanalítica kleiniana, a consideração e interpretação da ansiedade inconsciente, que se baseia na fantasia inconsciente.

O funcionamento inicial da criança ocorre através da vida de fantasia que, progressivamente através das relações objetais, cederá lugar às emoções mais complexas e aos processos cognitivos. Pode-se dizer que a criança de tenra idade suplementa a lógica pela vida fantasmática, na qual estão sempre presentes tanto fatores biológicos quanto ambientais, determinando que as fantasias, embora obedeçam a certos padrões, sejam infinitamente variáveis.

Constatou-se que as mulheres indicadas ao transplante de coração estabelecem relações objetais persecutórias correspondentes às fases mais arcaicas do desenvolvimento esquizoparanóide e viscocárica. Fantasias inconscientes e defesas arcaicas apareceram na avaliação das candidatas. A doença cardíaca grave para estas pacientes agiu como fator tensional (fator interno negativo) e foi vivenciado como perigo interno, induzindo a excessiva pressão das forças de morte e agravando tendências à negação e abandono do tratamento. Deste modo, foi remontada uma situação de retaliação vivenciada em tempos remotos e as forças de morte foram impulsionadas, fazendo com revivessem relações de objeto arcaicas, parciais (Tamagnini, 2009).

\subsubsection{Psicanálise e Psicossomática: Uma Importante Articulação}

A dinâmica das questões psicossomáticas vem ganhando campo nas investigações atuais. É apresentada uma alternativa para refletir sobre a intervenção da mente sobre o corpo que difere daquelas que pressupõe relações de causalidade. A Psicanálise não é ciência que explique causas, ela expõe processos, estruturas, sistemas complexos sendo, portanto, sua função, estabelecer conhecimento e não etiologia. 
Os primeiros estudos derivados da Psicanálise e que deram origem à Psicossomática moderna corresponderam ao problema da psicogenia de certos transtornos somáticos, como a asma brônquica, o eczema, a hipertensão essencial, úlcera péptica, hipertireoidismo, colite ulcerativa e enxaqueca. Atualmente, é concebida como questão de toda patologia, como uma percepção da dimensão simbólica da existência. É o que foi descrito na Medicina da Pessoa, postulando que a terapêutica deve ser moldada para aquele doente em especial e permitindo a singularização do caso clínico (Perestrello, 1974).

A Psicanálise se refere à psicologia em função do inconsciente, método de investigação da mente e atividade terapêutica. A Medicina Psicossomática trata do estudo das relações mente - corpo com ênfase na explicação psicológica da patologia somática, da transcrição para a linguagem psicológica dos sintomas corporais.

Ambas estão articuladas histórica e praticamente e há que se resgatar o psicanalista como o grande arquiteto do modelo psicossomático do século XX. Freud percebe a emergência de uma nova área do conhecimento, situada entre o corpo e a mente, e nos espaços intermediários das relações interpessoais: a Psicanálise visaria às raízes inconscientes destas relações.

Quatro contribuições da Psicanálise no campo médico são destacadas: como um método terapêutico das neuroses; um método de investigação da personalidade no qual os resultados favoreceriam no aumento da eficácia dos tratamentos psicológicos das caracteropatias, das psicoses e dos distúrbios emocionais da infância; uma psicologia em função do inconsciente cujo modelo possibilita a interpretação dos sintomas orgânicos em analogia àquela utilizada para os fenômenos conversivos; como um estudo das relações de objeto cujo modelo transferencial - contratransferencial esclarece alguns enigmas da relação médico - paciente (Eksterman, 1978). 
O termo psicossomática foi utilizado pela primeira vez por Heinroth, em 1818, ao fazer referência a insônia e à influência das paixões na tuberculose. Somente no século posterior é que foi retomado e influenciado pela Psicanálise. Recebe, então, importante contribuição com a enunciação da articulação entre o somático e o psíquico na distinção entre as psiconeuroses e as neuroses atuais e na descrição de uma nova possibilidade diagnóstica com a neurose de angústia, que caracterizou os sintomas como manifestações imediatas da angústia, tratando-se da ausência ou insuficiência de elaboração psíquica da excitação sexual somática (Freud, 1996a).

O conceito de Psicossomática tem variado em função dos diferentes referenciais teóricos. Frequentemente são empregados os seguintes termos para ilustrar uma situação peculiar: fenômenos psicossomáticos, perfis psicossomáticos, conflitos específicos, doenças psicossomáticas.

Pode ser definido como o estudo sistemático das relações existentes entre os processos sociais, psíquicos e transtornos de funções orgânicas ou corporais. É um ramo do conhecimento que estuda e trata de questões humanas, da promoção de saúde que pertence, em um só tempo, ao orgânico, ao psíquico e ao social. Comumente encontramos na clínica pacientes que, frente a situações angustiantes ou desprazerosas, aumentam consideravelmente a quantidade de alimentos ingeridos e excretados, ou reagem inversamente apresentando sintomas de inapetência e anorexia. Também encontramos aqueles que se atiram em atividades ou buscam a acumulação de objetos materiais e que não conseguem atingir satisfação (Rodrigues \& Campos, 2005).

Podemos encontrar o conceito diluído em diferentes espaços do domínio psiquiátrico e da medicina geral, de modo que, seu uso indiscriminado pode levar a prejuízos em relação à sua especificidade. 
Autores psicodinâmicos consideram a somatização remanescente de fases mais arcaicas do desenvolvimento da personalidade, afirmando que a criança, desde cedo, vivencia situações de estresse e aprende a reagir somaticamente aos estímulos. Depois de adultas, falhando mecanismos eficazes de enfrentamento, volta a lançar mão dos recursos primitivos.

No sentido mais preciso, circunscreve a áreas específicas, sobrepostos ou não, quando se refere à medicina psicossomática, doenças psicossomáticas ou psicossomática (Cerchiari, 2000).

O termo pode ser usado para indicar um método de abordagem em pesquisas e terapia, tratando-se do uso simultâneo de métodos e conceitos tanto somáticos quanto psicológicos.

Fenômenos somáticos e psíquicos ocorrem ao mesmo tempo no organismo, são dois aspectos de um mesmo processo, o que faz pensar que cada doença é psicossomática uma vez que os fatores emocionais influenciam nos processos do corpo (Alexander, 1989).

$\mathrm{Na}$ escola americana, o conceito de psicossomática é empregado como conseqüência de estados de tensão crônica com expressão inadequada das múltiplas vivências derivadas do corpo. É defendida a questão da especificidade da doença (visão psicogenética), referente a fatores psicológicos específicos, predisposição para determinadas doenças conforme os tipos de personalidades, além de empregado em estudos de perfis (Cardoso, 1995; Alexander, 1989; Dunbar, 1943).

Seguindo esta perspectiva, na década de 50 foram investigados pacientes com doenças coronarianas. $\mathrm{O}$ estudo concluiu que determinados indivíduos que apresentam urgência de tempo, associada à intensa hostilidade, fluência verbal, atividade psicomotora importante, comportamentos voltados à ambição e competição, denominados como 'personalidade tipo A', estariam mais suscetíveis a doenças coronarianas (Friedman, 1977, 1978; Friedman \& Rosenman, 1959). 
A escola francesa, por sua vez, concebe uma forma peculiar de pensamento e de lidar com emoções (Silva \& Caldeira, 1992). Postula-se a hipótese de que há uma estrutura psíquica em determinados pacientes que se assemelha às estruturas neurótica, psicótica e perversa, conhecida como pensamento operatório, que se traduz como uma dificuldade (ausência de palavras) para descrever emoções (Marty \& Múzan, 1983; Sifneos, 1973). A utilização de uma escuta analítica constata que os pacientes "não falavam sobre nada". Este "nada" possibilitou aos investigadores franceses a formulação de um conceito vinculado à negatividade simbólica, onde o pensamento operatório, a precariedade onírica e a ausência de fantasia se impunham como esfinges aos decifradores dos sintomas psicossomáticos. A psicossomática seria, neste contexto, uma abordagem de pacientes, uma técnica psicoterápica e uma teoria (Dias, 1992; Rocha, 1989).

A imagem mitológica da Esfinge pode ser considerada o símbolo do enigma psicossomático: é construída de partes de figuras diversas (cabeça de mulher, corpo de leão, asas de águia e cauda de serpente) e a Édipo é dada a tarefa de decifrar este enigma, reunindo o que parece separado, mente e corpo. Freud está engajado nesta empreitada (enigma), a de descobrir a unidade essencial do homem.

Outro termo utilizado nos últimos anos como tentativa de explicar este processo é o de alexitimia, no qual as representações ou percepções repletas de afeto se distanciam da mente. Deste modo, as tensões físicas permanecem apenas no campo físico, por não encontrarem vias de atingirem o campo psíquico (Silva \& Caldeira, 1992). Defende-se a idéia da presença da pulsão de morte nos fenômenos psicossomáticos, como o principal responsável pela desorganização psíquica identificada nestes casos (Marty \& Muzan, 1983). Estudos abordam também a relação existente entre alexitimia e patologias diversas, como o câncer de mama (Cerchiari, 2000). 
A compreensão dos fenômenos psicossomáticos de um ponto de vista essencialmente psicanalítico pode ser relacionada às vicissitudes e falhas no processo de individuação e que formatam a subjetividade. A somatização, associada à economia do afeto, é compreendida como um modo de defesa arcaico, anterior à constituição da linguagem, resultado de falhas no processo de internalização que constroem a identidade subjetiva: preenche as lacunas entre o desejo de fusão e o de individuação e apropriação psíquica do corpo. O "agir arcaico" dos pacientes se dá sob a forma de uma descarga direta, expulsando do psiquismo e derivando para o corpo as percepções e fantasias ou pensamentos que suscitam afetos insuportáveis, associados às vivências traumáticas e precoces presentes no desenvolvimento infantil (McDougall, 1991).

Os primeiros pacientes portadores de distúrbios orgânicos crônicos, relacionados às alterações emocionais que receberam estudo mais aprofundado, foram os pacientes histéricos, nos quais ocorria o fenômeno de conversão, que consiste na transposição de um conflito psíquico e uma tentativa de sua resolução em sintomas somáticos ou motores, como exemplo, uma paralisia ou sensitivos, uma anestesia ou dor acentuada (Freud, 1996a).

A expressão "complacência somática" é introduzida por Freud para se referir à escolha da neurose histérica e a eleição do órgão ou do aparelho corporal sobre o qual se dá a conversão: o corpo ou órgão específico facilitaria a expressão simbólica do conflito inconsciente (Laplanche \& Pontalis, 1995).

No caso Dora de 1905, é levantada a questão referente à origem psíquica ou somática dos sintomas histéricos. O cerne não estaria entre escolher uma ou outra, uma vez admitida a presença da atuação de ambas em todo sintoma histérico.

O sintoma seria possível apenas com a admissão de uma complacência somática, fornecida por um processo normal ou patológico de um órgão do corpo ou com ele 
relacionado. Esta complacência proporcionaria aos processos psíquicos inconscientes uma saída corporal (Freud, 1996f).

Um sintoma conversivo é a expressão simbólica de um conflito intrapsíquico, ocorre nos sistemas neuromuscular voluntário ou perceptivo sensorial e tem como função expressar e descarregar a tensão emocional, decorrente do conflito. A somatização, por sua vez, não é uma tentativa de expressar emoções, é a própria expressão das emoções, a resposta fisiológica (Rodrigues \& Campos, 2005).

Freud afirmou que a pulsão sexual está imperativamente direcionada para a descarga, de modo que essa tem que acontecer de uma maneira ou de outra. Logo, se nos pacientes somatizantes a libido não é descarregada pela via fantasmática, isto é, através das representações psíquicas, isso significa que ela se encontra livre e pronta para ser descarregada por onde der. No caso dos pacientes somatizantes, a saída disponível será, evidentemente, o corpo.

No entanto, a descarga pela via do corpo não significa necessariamente uma doença psicossomática. Em vez da somatização, o sujeito pode fazer uso de uma defesa que Freud chamou de "acting-out", isto é, uma atuação.

O interesse pela neurose perturbadoramente incomodava o objetivo raciocínio médico, à medida em que a história de vida do paciente foi considerada como importante caminho de investigação. O conceito de pulsão foi desenvolvido com como intermediário entre o somático e o psíquico, caracterizado como fonte da vida psíquica.

Deste modo, tornou-se cada vez mais impossível para os psicanalistas se absterem deste vértice de observação, já que não há maneira de compreender a mente se não incluirmos nesta compreensão a existência da corporeidade (Della Nina, 2004). 
A idéia de que, na etiologia de uma neurose não estaria mais o fato e sim uma fantasia sobre o ocorrido / acontecido, abriu caminho para uma nova forma de se pensar o psiquismo e a própria formação dos processos mentais.

A prática psicanalítica se depara com dificuldades quando a abordagem deve se processar em relação aos eventos que estão além da consideração das manifestações simbolicamente expostas. Assim, passa a incluir em sua avaliação as denominadas somatizações e todas as etapas do desenvolvimento psíquico que antecedem o processo de simbolização.

Constituíram-se como importantes contribuições para a compreensão da articulação corpo - mente, trabalhos que antecederam a eclosão da teoria da pulsão e dos sonhos, como "Projeto de uma Psicologia para Neurologistas" e "Sobre as Afasias" (Freud, 1996g, 1996h).

Se olharmos os sintomas apenas do prisma biológico e ignorarmos a história do paciente, faltarão instrumentos para o atendimento clínico e para a seleção da melhor terapêutica. O ser humano apresenta capacidade de responder às ameaças da vida, concretas ou não e, as situações que podem representar rupturas de laços familiares e estrutura social, privação de necessidades afetivas, obstáculos a realizações pessoais entre outras, são potencialmente danosas e aumentam a vulnerabilidade (Rodrigues, 1987).

Só mesmo através da atenção às emoções e afetos é possível fazer um diagnóstico diferencial entre um quadro orgânico por excelência, um quadro orgânico agravado pelas emoções e um quadro eminentemente psíquico com sintomatologia orgânica (Ballone, 2007).

Fatores psicossomáticos podem influenciar na instauração e manutenção de doenças. A externalização dos conteúdo somatizados colabora para o alívio do sofrimento e melhora da qualidade de vida dos pacientes, o que enfatiza a importância da presença do psicólogo na equipe multidisciplinar (Arrais, Oliveira, \& Paula, 2012). 
O que ocorre nos processos mentais, em termos de objetos internos e símbolos, constitui o componente latente do sintoma clínico, enquanto que, o que se passa ao nível dos órgãos, compõe o sintoma manifesto (Pontes, 1974).

Quando o conflito intrapsíquico se torna intenso e persistente, a emoção gera tensão que buscará um escoamento por acesso emocional e somático, favorecendo a manutenção da homeostase psíquica; o conteúdo do conflito nem sempre se mostra de maneira clara e pode não estar presente de forma manifesta, explícita, na consciência. Em função disso, o conteúdo de tal conflito sofre uma tradução que é expressa na formação do sintoma (Campos \& Rodrigues, 2005).

O conflito intrapsíquico ocorre quando surgem representações mentais com exigências internas contrárias, como ocorre entre o desejo e prescrições morais ou entre sentimentos contraditórios. Embora seja constitutivo do ser humano, o conflito pode ser fonte de intensa insatisfação e sofrimento (Laplanche \& Pontalis, 1971).

Quando se torna persistente, a emoção decorrente gera um estado de tensão que buscará escoamento por vias emocional e somática, com o intuito de atingir a manutenção da homeostase psíquica. Este conteúdo nem sempre é claro e manifesto na consciência, sofrendo uma tradução que é expressa na formação do sintoma.

Uma síndrome hipoestênica, por exemplo, pode ser apresentada por pacientes que estabelecem relações objetais negativas e experimentam dificuldades para aceitação das condições de vida: estão frequentemente deprimidos, escondem sentimentos de hostilidade em relação ao mundo interno e dispõem de objetos internos destrutivos (Rodrigues \& Campos, 2005).

Conforme Freud expôs em sua teoria estrutural: a Psicanálise é o momento em que a carne se faz verbo, ou seja, em que o id se transforma em ego. O entendimento desta 
transformação faz parte da psicossomática e a compreensão do processo faz parte do saber psicanalítico.

Este é o ponto de intersecção entre Psicanálise e Medicina Psicossomática. O corpo se representa e se recria na mente, produzindo significados que permitem a intervenção de um interlocutor (psicanalista). A observação empírica da aparente influência dos processos mentais sobre as funções somáticas é que originou as especulações sobre a gênese psicológica dos transtornos somáticos.

Pode-se entender, deste modo, como a dinâmica mental constrói a realidade externa e é responsável por acionar os mecanismos adaptativos do organismo. Esta realidade externa é construída a partir do universo simbólico do psiquismo. A mente, então, construindo suas concepções de mundo, experimenta estas criações como reais e transforma a realidade externa (Eksterman, 1992)

Possivelmente, o início do avanço dos concepções psicanalíticas de Melanie Klein começou com Luto e Melancolia (Freud, 1996b), quando foi introduzido o conceito de "objeto" e, posteriormente, com a psicologia das massas, a análise do ego e a noção do superego. Foram os estudos de Klein e seus seguidores que desenvolveram estes passos iniciais, com influência de Luto e Melancolia, Além do Princípio do Prazer e noções sobre os impulsos de vida e de morte (Eksterman, 1992).

Mente e corpo se articulam para produzir prazer, sofrimento, saúde, lesão ou doença e o luto pode ser patológico nas identificações simbólicas com o objeto morto: as perdas emocionais empobrecem o ego, vulnerabilizando o corpo na medida em que seu espaço simbólico carece de objetos amorosos e protetores.

Pensando na escolha somática, devemos considerar a participação do sistema cardiovascular em situações de estresse. Desde os primórdios do desenvolvimento, a criança vivencia situações de estresse às quais, muitas vezes, aprendeu a agir somaticamente. Assim, 
é razoável supor que, na vida atual, volte a lançar mão destes recursos na falta de meios mais eficazes de enfrentamento (Campos, 1992).

De acordo com Melanie Klein, nas phantasias inconscientes se encontra a origem de todas as ocorrências psicossomáticas, com valores afetivos e significados profundos: estão repletas de conteúdos inconscientes primários e se referem à "produtividade' da unidade somatopsíquica, situando-se em um plano de abstração mais profundo do que qualquer fantasia que possa ser acessada e reconhecida (Spillius, 2005; Figueiredo, 2006).

Os estudos das relações de objeto de Melanie Klein só fez ampliar a importância do construto teórico fundamental da Psicanálise, o inconsciente. Este conceito originou mudanças importantes entre concepções de tratamento atuais. Hoje, estamos comprometidos com novos objetivos terapêuticos, principalmente com a superação do sofrimento. 


\title{
1.3 A DOENÇA CARDIOVASCULAR E O PACIENTE CARDIOPATA
}

\begin{abstract}
"Devemos, no entanto, reconhecer, como me parece, que o homem com todas as suas nobres qualidades, ainda sofre em sua prisão corpórea a indelével marca de sua humilde origem."

Charles Darwin
\end{abstract}

\subsubsection{Insuficiência Cardíaca (IC) e Classe Funcional (CF) NYHA PARA IC}

No Brasil, as doenças cardiovasculares respondem por $65 \%$ do total de óbitos de adultos entre 30 e 69 anos. A insuficiência cardíaca (IC) é uma doença de alta prevalência entre as doenças cardiovasculares (DCV).

Apesar dos inquestionáveis avanços terapêuticos alcançados nas últimas décadas, o prognóstico da IC depende de diversos fatores de predição, sendo responsável por elevados índices de morbidade e mortalidade em todo o mundo (Roger, Go, Lloyd-Jones, Benjamin, \& Adams, 2012).

Anualmente, a IC apresenta mortalidade de $30 \%$ a $50 \%$ para os pacientes mais graves (Muntwyler, Abetel, Gruner \& Follath, 2002).

Avanços científicos / tecnológicos não são os únicos responsáveis pela queda na das taxas de mortalidade. O tratamento responde por menos de $50 \%$ desta redução, que está efetivamente relacionada aos fatores de risco (FR) que envolvem a doença.

A limitação da capacidade física em IC é descrita de acordo com a classificação funcional da New York Heart Association (NYHA):

- $\quad$ Classe Funcional I (CF I): pacientes sem limitação de atividades, pois não sofrem sintomas durante as atividades diárias;

- $\quad$ Classe Funcional II (CF II): pacientes com limitação leve de atividade, pois se sentem confortáveis em repouso ou com esforço leve; 
- Classe Funcional III (CF III): Pacientes com moderada limitação da atividade, pois se sentem confortáveis apenas em repouso,

- $\quad$ Classe Funcional IV (CF IV): pacientes que deveriam ficar em repouso completo, confinados à cama ou cadeira, pois qualquer atividade física traz desconforto e os sintomas ocorrem em repouso.

\subsubsection{Transplante Cardíaco (TC) e o Paciente Cardiopata Grave}

O transplante cardíaco é, atualmente, a única alternativa cirúrgica amplamente aceita para tratar pacientes com IC grave. Apesar dos avanços no tratamento clínico nos últimos anos e decorrente aumento da expectativa de vida, o TC persiste sendo o tratamento para a IC refratária, mesmo na ausência de estudos randomizado-controlados (Bacal, Souza Neto, Fiorelli, Mejia, \& Marcondes - Braga, 2009).

Pacientes portadores de IC avançada, classificados pela NYHA como CF III ou IV, com sintomas graves, sem alternativa para tratamento clínico e com prognóstico desfavorável são indicados para o TC (Dickstein, Cohen-Solal, Filippatos, McMurray, Ponikowski et al., 2008; Mehra, Kobashigawa, Starling, Russell, Uber et al., 2006).

O conceito de cardiopatia grave engloba tanto doenças cardíacas crônicas como agudas. São consideradas cardiopatias graves (Dutra, 2006):

- cardiopatias agudas: que evoluem rapidamente para crônicas e são caracterizadas pela perda da capacidade física e funcional do coração;

- cardiopatias crônicas: quando limitam, progressivamente, a capacidade física e funcional do coração;

- cardiopatias crônicas ou agudas: com dependência total de suporte inotrópico farmacológico ou mecânico, 
- cardiopatia terminal: cardiopatia grave em que é diminuída a expectativa de vida, que não responde a tratamento farmacológico, não é indicada ao tratamento cirúrgico de correção do distúrbio de base ou transplante cardíaco devido à gravidade do quadro e comorbidades clínicas associadas.

Geralmente, os pacientes que são indicados à cirurgia de TC podem ser incluídos em dois grupos:

- com danos irreversíveis causados pela doença das coronárias, sob forma de ataques cardíacos,

- com a doença do músculo propriamente dita (cardiomiopatia).

O primeiro transplante cardíaco foi realizado em 1967 na cidade do Cabo, África do Sul, por Christian Barnard. Foi submetido à cirurgia de enxerto um paciente de 55 anos que recebeu seu novo coração na esperança de prolongar sua expectativa de vida para além dos anos que lhe restavam com sua cardiopatia incurável. Resistiu 18 dias após a cirurgia e o procedimento, desde então, se tornou um marco na história da medicina. Após seis meses o primeiro transplante é realizado no Brasil.

Para que seja indicado a um transplante de coração, o paciente se submete, inicialmente, a exames complementares no intuito de que sejam descartadas doenças associadas que possam atuar como fatores de risco (FR) para a sua sobrevida.

A prioridade de transplante para os pacientes hospitalizados em condições críticas é mundialmente aceita. Quanto aos pacientes ambulatoriais, as condições que estão associadas à mortalidade da IC (fatores prognósticos) são utilizadas como determinantes da indicação ao TC. No Brasil e em outros países, o tempo de espera pelo enxerto é também utilizado como critério de prioridade à indicação (Areosa, Almeida, Carvalho, \& Paola, 2007).

Com a escassez de órgãos, foram criados sistemas para identificar a gravidade dos pacientes e selecionar o indicado à cirurgia. No Brasil, usa-se a classificação por priorizados 
ou não-priorizados. Um estudo intitulado COCPIT, realizado na Alemanha, demonstrou a importância desta classificação (priorizados e não-priorizados) na evolução dos pacientes: conclui que, apenas pacientes com risco severo de morte, de acordo com o Heart Failure Survival Score (HFSS) são beneficiados, em termos de sobrevida, com a cirurgia de transplante cardíaco. Conclui também que pacientes de baixo e médio risco não apresentam nenhuma redução de mortalidade e que devem ser manejados com outras formas de tratamento (Deng, De Meester, Smits, Heinecke, \& Scheld, 2000).

A manutenção da qualidade de vida para estes pacientes parece ter importância fundamental, uma vez que o estudo sugere outras formas de tratamento que não o TC.

Como exemplo desta necessidade, verificou-se que a doença de Chagas pode ser reativada após o transplante devido à imunossupressão, sendo necessário um diagnóstico precoce para que se instaure uma terapia preventiva e para que esta não seja considerada uma contraindicação ao procedimento (Campos, Strabelli, Amato, Bocchi, Bacal et al., 2008).

São encontrados inúmeros materiais a respeito do tratamento segundo a condição clínica do paciente, porém poucos acerca do TC como intention to treat ou dados referentes ao custo - efetividade do tratamento. Não existem ensaios clínicos randomizados em torno do TC.

O TC tem alta taxa de mortalidade e o paciente CF IV é o que mais se beneficia com o enxerto por apresentar IC grave: esgotamento do tratamento medicamentoso, máxima terapêutica médica, inaceitável qualidade de vida devido a sintomas e alto risco de morte.

Um dos maiores fatores para o não sucesso da cirurgia de $\mathrm{TC}$, inicialmente, era a rejeição do órgão implantado. Atualmente, com a introdução dos imunossupressores, como a Ciclosporina em 1980, o quadro de mortalidade foi reduzido (69\% de sobrevida no primeiro ano após o enxerto; 44,7\% de sobrevida após dez anos). 
Alguns critérios de indicações e contraindicações têm sido modificados nos últimos anos, principalmente com relação à idade, consumo de oxigênio no teste cardiopulmonar (TCP), resistência vascular pulmonar (RVP), obesidade, câncer, diabetes melito, insuficiência renal (IR), pacientes sensibilizados, doença vascular periférica (DVP) e dependência de drogas (Bocchi, Marcondes - Braga, Bacal, Ferraz, Albuquerque et al., 2012).

Variáveis prognósticas são utilizadas na seleção do candidato ao TC, a fim de identificar aqueles com IC avançada, combinadas com contraindicações e comorbidades que podem acarretar em desfechos desfavoráveis, como alto risco perioperatório (nas fases pré operatória, trans - operatória e pós - operatória) e redução de sobrevida pós-enxerto. Esse processo de seleção requer equipe multidisciplinar com profundo conhecimento do prognóstico e manejo dos pacientes com IC avançada (Mehra et al., 2006).

As indicações e contraindicações, para o TC são as seguintes (Bacal et al., 2009):

Tabela 1. Indicações para TC

\begin{tabular}{|c|c|}
\hline Classe de Recomendação & Indicações \\
\hline CLASSE I & $\begin{array}{l}\text { - IC refratária na dependência de drogas inotrópicas e/ou de } \\
\text { suporte circulatório e/ou ventilação mecânica } \\
\text { - VO2 pico } \leq 10 \mathrm{ml} / \mathrm{Kg} / \mathrm{min} \\
\text { - Doença isquêmica com angina refratária sem possibilidade de } \\
\text { revascularização } \\
\text { - Arritmia ventricular refratária } \\
\text { - Classe funcional III/IV persistente }\end{array}$ \\
\hline CLASSE IIa & $\begin{array}{l}\text { - Teste da caminhada dos } 6 \text { minutos }<300 \text { metros } \\
\text { - Uso de } \mathrm{BB} \text { com } \mathrm{VO} 2 \text { pico } \leq 12 \mathrm{ml} / \mathrm{Kg} / \mathrm{min} \\
\text { - Sem uso de } \mathrm{BB} \text { com } \mathrm{VO} 2 \text { pico } \leq 14 \mathrm{ml} / \mathrm{Kg} / \mathrm{min} \\
\text { - Teste cardiopulmonar com relação } \mathrm{VE} / \mathrm{VCO} 2>35 \text { e } \mathrm{VO} 2 \\
\text { pico } \leq 14 \mathrm{ml} / \mathrm{Kg} / \mathrm{min}\end{array}$ \\
\hline CLASSE III & $\begin{array}{l}\text { - Presença de disfunção sistólica isolada } \\
\text { - Classe funcional III/IV sem otimização terapêutica }\end{array}$ \\
\hline
\end{tabular}


Tabela 2. Contraindicações absolutas para TC

Contraindicações Absolutas para Transplante Cardíaco

- Resistência vascular pulmonar fixa > 5 Wood, mesmo após provas farmacológicas

- Doenças cerebrovascular e/ou vascular periférica graves

- Insuficiência hepática irreversível, doença pulmonar grave

- Incompatibilidade ABO na prova cruzada prospectiva entre receptor e doador

- Doença psiquiátrica grave, dependência química e não aderência às recomendações da equipe

De acordo com os dados da II Diretriz Brasileira de Transplante Cardíaco, destacam-se nas contraindicações absolutas para TC: doenças psiquiátricas graves, dependência química e não aderência às recomendações da equipe. Para tanto, faz-se necessária a avaliação psicológica do paciente a fim de detectar as características que se interpõem à indicação da cirurgia de enxerto (Bacal et al., 2009).

O pré-transplante pode ser vivido como um momento de ambigüidade e confusão devido à sobrecarga emocional pela qual o paciente passa, sendo o atendimento psicológico fundamental para um enfrentamento adequado (Campos, Bach, \& Alvares, 2003). Fantasias de negação da morte e mutilação são frequentemente encontradas entre os familiares do doador (Moraes, 2009).

Neste ponto caberia salientar as implicações de ordem psicológica no caso dos transplantes: assim como pode haver rejeição física, também pode haver uma rejeição psíquica do paciente. Deve-se considerar a necessidade de um período de elaboração do paciente sobre o que está passando, pois há a possibilidade de que ocorra dificuldade para a integração de um órgão que não é dele. Pode surgir, ainda, um sentimento de perda da 
integridade ou de culpa em relação ao doador: o paciente estará vivo à custa de alguém que morreu (Torres, 2003).

A cirurgia cardíaca é um grande evento na vida do paciente, primeiro porque, sendo um procedimento complexo e não fisiológico, tanto pode preservar a vida e melhorá-la quanto extingui-la. Para quem opera do coração, há sempre a idéia de "tudo ou nada", não importam dados anteriores em relação à sobrevida de pacientes. A maioria dos adultos que se submeteram à cirurgia cardíaca apresenta alto nível de ansiedade, dando origem a fantasias e medos ligados à morte, elementos geradores de alterações emocionais. Não levar em conta estes fatores pode comprometer e prejudicar a evolução pós-operatória (Oliveira \& Luz, 1992).

A aceitação da cirurgia, principalmente pelo assintomático, é difícil, uma vez que não se sente doente. A intervenção do psicólogo é importante principalmente para enfatizar que a decisão final sobre o tratamento cirúrgico é do paciente. A partir deste momento, o paciente sente maior controle sobre a situação, o que diminui a ansiedade, resultando em um pósoperatório imediato menos estressante para o doente, família e equipe que o assiste (Oliveira \& Luz, 1992).

Enfrentar uma situação real de possibilidade de morte representa um momento de angústia e insegurança. A compreensão dos aspectos psicodinâmicos envolvidos no processo saúde - doença é parte fundamental da avaliação psicodiagnóstica destes pacientes.

\subsubsection{Processos Psíquicos no Paciente Cardiopata}

Sabemos que, fisiologicamente o comando da vida física e a modulação do comportamento estão centralizados no cérebro. No entanto, é o coração que simboliza o sentimento humano. Ficar com o "coração partido" é como admitir que o coração é o centro 
das emoções. Assim, não nos causa surpresa que afecções cardíacas exerçam forte impacto sobre os sentimentos e comportamentos humanos (Oliveira \& Luz, 1992).

É clara e legítima a vinculação dos aspectos emocionais ao sistema cardiovascular. Estudos recentes mostram que as interações emoção - coração tem correspondentes bioquímicos bem definidos.

Alterações emocionais foram descritas em associação com doença arterial coronária que precediam infarto do miocárdio (IAM), crises de angina e morte súbita, bem como agravantes de hipertensão arterial (HAS). Estimulações do sistema simpático de modo geral excitam o coração, aumentando a frequência cárdica, a força de contração e a pressão arterial (Jenkins \& Zyzansky, 1980; Theodore, 1987; Theorell, 1973; Albus, 2010; Brezinka, \& Kittel, 1996; Khayyam-Nekouei, Neshatdoost, Yousefy, Sadeghji, \& Manshaee, 2013; Steptoe, 1999; Rozansky, Blumenthal, \& Kaplan, 1999; Oliveira \& Luz, 1992).

A simbolização atribuída ao coração, desde a antiguidade, é significativa e atravessa toda a história da humanidade.

A capacidade de simbolizar foi desenvolvida pelo homem devido sua necessidade de se expressar. No entanto, esta simbolização pouco tem a ver com o coração anatômico, está relacionada ao órgão como centro da vida, da coragem e da razão (Prates, 2005).

Considerando todo o simbolismo atribuído ao coração, sentido como fonte de vida e sede das emoções, é possível pensar em sua utilização como veículo de expressão simbólica.

O coração é uma das representações mais nobres da corporalidade do ser humano, pois sem ele perdemos a autoconsciência: a simbolicidade e corporalidade (Rosa, 1997).

Estudos que abordam a relação entre fatores emocionais como sendo uma das causas de origem da enfermidade, demonstram também o impacto da doença na qualidade de vida dos pacientes: confirmam que a avaliação psicológica e identificação de fatores de risco no período pré - operatório são necessárias porque o estado emocional do paciente interfere 
diretamente em suas reações no trans e pós - operatório (Barbosa \& Randomile, 2006; Hueb \& Loureiro, 2005; Oliveira, Santos, \& Mastropietro, 2010; Oliveira, Martins, Siqueira, Alvares, Laitano et al., 2012).

A enfermidade física pode alterar o equilíbrio psicológico dos pacientes por propiciar toda uma série de experiências estressantes durante seu curso.

$\mathrm{Na}$ cardiologia, sabe-se que fatores psicológicos podem precipitar distúrbios, como (Ballone, 2007):

- Transtornos de Ritmos: proeminentes nas arritmias mais comuns. A arritmia letal, fibrilação ou paralisia ventricular são causas possíveis morte súbita em resposta a um estímulo emocional opressivo ou ao desespero. Assim sendo, a ativação das respostas de estresse, do tipo luta - fuga e conservação - afastamento, pode provocar arritmias letais principalmente em pessoas com doença coronariana;

- Arteriopatia Coronariana: o estresse pode influenciar no surgimento de arteriosclerose: quando o nível de estresse é alto, há liberação de colesterol, que pode levar ao IAM,

- A Hipertensão Arterial: costuma ser uma perturbação hemodinâmica por múltiplas causas. A mobilização do Sistema Nervoso Autônomo, através de um aumento da atividade do sistema simpático e a conseqüente elevação da produção de renina está entre os supostos mecanismos patogênicos da hipertensão arterial. Interações de fatores genéticos, ambientais, de personalidade (Personalidade Tipo A), dietéticos, e comportamentais, certamente conduzem à elevação patológica persistente da pressão sangüínea.

O setor orgânico por sua vez, pode influenciar negativamente os demais (afetivo relacional, produtivo e sócio - cultural), interferindo significativamente na capacidade adaptativa do indivíduo (Simon, 2005). Esta influência foi verificada em estudo que abordou as correlações entre o controle glicêmico de diabéticos tipo II e a capacidade adaptativa. A 
pesquisa demonstrou que, para os pacientes com diagnóstico de adaptação eficaz e ineficaz leve, são suficientes algumas sessões de psicoterapia breve, informações sobre a doença e evolução clínica, enquanto que, para aqueles com adaptação moderada, severa e grave, é necessária a indicação imediata à psicoterapia (Heleno, 2000).

O conhecimento da cardiopatia pelo próprio paciente é extremamente acanhado, e não parece haver consciência desta realidade. Detecta-se uma postura absolutamente passiva e de alienação em relação à doença e tratamento por parte do paciente (Ballone, 2007).

A doença representa sempre uma ameaça, potencial ou concreta, à integridade física. Promove sofrimento, complicações futuras e ameaças de destruição; mobiliza reações de angústia, ansiedade e depressão, perante as quais os indivíduos utilizam defesas nem sempre eficientes para contê-las (Mello Filho, 1978; Haynal \& Pasini, 1980).

A forma mais elaborada de enfrentamento seria a de encarar conscientemente podendo falar, discutir e refletir sobre a situação e, quando isso não é possível, outros meios de enfrentamento são utilizados: mentais (fantasiar, racionalizar, negar, rezar), emocionais, (deprimir, agredir, culpar, chorar, gritar), atitudinais (isolar-se, exsibir-se, brincar, arriscar-se), aditivas (comer, beber, fumar, trabalhar excessivamente) e somáticas (adoecer). Quanto menos os mecanismos mentais ou cognitivos de falar e agir estiverem funcionando, mais será utilizado o mecanismo somático. Esta é a forma primitiva de expressão e defesa, o indivíduo fala com o corpo e com ele se defende: obtém atenção e cuidados, exprime desejos e fantasias, enfrenta situações de estresse, através dele se recrimina e também se culpa (Campos, 1992).

A vida psíquica é constituída de um somatório de experiências atuais e passadas, percebidas e registradas de forma pessoal. Em se tratando do coração, os caminhos e os modos através dos quais as emoções repercutem seguem em constantes discussões. As emoções constituem uma classe de fenômenos que são sentidos internamente e expressos 
externamente, através de sinais somáticos e comportamentais, como ocorre no amor, no medo e na raiva. É a emoção que exerce função expressiva, informando e sinalizando uma situação ameaçadora para o indivíduo.

As reações emocionais e psíquicas do enfermo são uma realidade do dia-a-dia do profissional da saúde. Obrigatoriamente o clínico, de qualquer especialidade, deve considerar os aspectos fundamentais que envolvem o paciente e sua enfermidade: quais as reações e sentimentos foram observados frente à doença (qual a representatividade da doença) e o que sabe sobre os objetivos e procedimentos médicos aos quais será submetido, além de realizar um diagnóstico diferencial que contemple as possíveis somatizações (Ballone, 2007).

A principal função do processo emocional é a avaliação das informações que são captadas do ambiente por órgãos sensoriais, que tem como objetivo final a autopreservação. Tudo o que ameace este objetivo, será fonte de sensações desagradáveis. A capacidade de expressar psiquicamente (simbolicamente) a experiência cria um novo mundo de pensamentos, fantasias, desejos, reflexão e raciocínio, passando a representar uma fonte de ameaça ou satisfação, fonte de recursos para garantir o enfrentamento ou de adaptação às situações (Campos, 1992).

Queixas funcionais ou distúrbios orgânicos podem estar a serviço das emoções. No distúrbio orgânico cardíaco prévio, as razões emocionais atuariam como expressivos agravantes no paciente psicossomático. A tendência à autopunição desses pacientes poderia ser percebida através da atitude da pessoa diante da doença. Vemos essa ocorrência no desleixo ao cumprimento da prescrição médica, nas provocações quase propositais dos sintomas e agravamentos.

Essa tendência autopunitiva é mais evidenciada ainda na atitude da Desistência Depressiva. Aqui o paciente "dá a impressão" de não burlar o tratamento, mas seu desinteresse em curar-se é tão intenso, que os esforços terapêuticos são em vão. Essa teoria 
pode explicar porque alguns pacientes acabam falecendo pouco tempo depois da morte do(a) cônjuge (Ballone, 2007).

É fato a repercussão cardiovascular face a situações estressantes ou ansiogênicas, mas o modo de enfrentamento é peculiar, resulta da história do paciente e das circunstâncias: a opção por este ou aquele tipo de enfrentamento depende de predisposições constitucionais das primeiras experiências de vida, das normas e valores introjetados, da qualidade das relações objetais e das fantasias inconscientes envolvidas no processo.

\subsubsection{Fatores de Risco na DCV}

A principal causa de mortalidade e incapacitância no mundo é a de doença cardiovascular: DAC chefiada pelo IAM seguido pelo AVC. No Brasil temos a inversão: AVC seguido de IAM. O estado de São Paulo segue a ordem mundial: IAM seguido de AVC (O’Donnell, Xavier, Liu, Zhang, \& Chin, 2010; Avezum, O’Donnell, Xavier, Diener, \& Sacco, 2010; Avezum, Yusuf, Hawken, Ôunpuu, \& Dans, 2004).

Sabe-se, atualmente, que fatores orgânicos como hipertensão, obesidade e diabetes explicam apenas $40 \%$ das ocorrências de doenças cardíacas. Acredita-se que a variabilidade da expressão das emoções (inibição ou intensidade) traga conseqüências para a saúde, sendo que, a inibição demanda esforço psicológico que pode acarretar em estresse cumulativo (Kubzansky \& Kawachi, 2000). Neste sentido, os fatores psicossociais podem aumentar a predisposição a eventos cardíacos (Rozanski, Blumenthal, \& Kaplan, 1999).

No que se refere ao TC, pesquisas no campo da Psiquiatria mostram que mais de $70 \%$ dos programas de transplante no mundo reconhecem como critérios de exclusão ao procedimento no momento da avaliação: quadro de esquizofrenia com sintomas psicóticos 
agudos, ideação suicida, histórico de tentativas de suicídio, demência, retardo mental severo, abuso de álcool e outras dependências químicas (Levenson \& Olbrisch, 1991).

Estudos sugerem que a depressão é um dos principais fatores de risco, não somente para o desenvolvimento da doença coronariana, mas também de mortalidade entre os pacientes que tiveram um IAM, sendo o principal fator de aumento de risco de morte no ano seguinte ao IAM (Petersom, Williams - Russo, Charlson, \& Meyers, 1996; Frasure-Smith, Lesperance, \& Talajie, 1995).

A depressão, se identificada, pode gerar indicação relativa ao transplante, mas se não tratada e contemplada pela equipe multidisciplinar, poderá se tornar uma contraindicação absoluta à medida que favorece a não-aderência às recomendações da equipe.

Tabela 3. Critérios de Avaliação Psicológica do Candidato ao TC

Avaliação Psicológica para TC

- A condição psicológica do paciente é compatível com a situação clínica. Observam-se recursos psicológicos defensivos adaptativos que mantém a esperança e permitem suportar o sofrimento físico e

Indicações subjetivo. Boa estrutura familiar e rede de apoio social;

- A condição psicológica do paciente é reativa à presença e à gravidade da doença. Não há evidências, no histórico do paciente, de reações inadaptadas frente a estressores psicossociais. Boa estrutura familiar e rede de apoio social.

- Falhas na adesão ao tratamento associadas a condições previstas Contraindicações no Eixo II do DSM IV e distúrbios de desenvolvimento e de Relativas personalidade), incluindo-se a categoria - personalidade tipo D (distresse), acrescidas de falta de suporte familiar e social.

- Dependência química (abstinência inferior a seis meses e fatores Contraindicações tentativas de suicídio pregressas associadas a distúrbios mentais do Absolutas Eixo I e/ou II do DSM IV. Retardo mental impeditivo para compreensão mínima do tratamento vinculado à falta e/ ou à negligência de cuidadores. 
Podem ser considerados fatores de risco ao TC a constatação de comorbidades ou de distúrbios mentais que comprometam a compreensão dos procedimentos e o cumprimento do protocolo pré e pós-cirúrgico. O termo comorbidade é amplamente utilizado por profissionais de saúde mental, nas esferas psicológica e psiquiátrica. O conceito atual refere-se à associação, mais que informal, mas provavelmente não causal, entre uma doença ou transtorno índice e uma ou mais patologias físicas ou psicológicas (Angold, Costello, \& Erkanli, 1999).

$\mathrm{Na} \mathrm{DCV}$, são considerados fatores de risco psicológicos à sobrevida:

- Distúrbios mentais que comprometam a compreensão dos procedimentos e cumprimento de protocolo;

- Fatores psicossociais que podem impedir a adesão do paciente ao regime médico;

- Depressão e ansiedade que merecem diagnóstico diferencial devido à debilidade gerada pela IC grave e as fantasias que emergem pelo fato de vir a possuir o coração de outra pessoa, assim como a desesperança, que pode ser um fator de risco associado à mortalidade na fase de espera pelo enxerto (Brandwin, Trask, Schwartz, \& Clifford, 2000).

A depressão é uma das maiores causas de morbidade e uma das doenças com maior impacto na qualidade de vida. Pode ser considerada FR para desfechos desfavoráveis em DCV e em associação com a IC (May, Horne, Carlquist, Sheng, \& Joy, 2009; Margoto, Colombo, \& Gallani, 2009; Rossi Neto, 2004).

Esta associação é importante, uma vez que a IC, preditor de mortalidade na SCA, é considerada um grande problema de saúde pública afetando cerca de 6,4 milhões de brasileiros, com incidência de, aproximadamente, 10 casos por 1000 indivíduos com mais de 65 anos.

Os principais FR associados ao IAM na região metropolitana de São Paulo são: tabagismo, HAS, LDL - colesterol, DM, história familiar de ICO, HDL - colesterol. No 
Brasil, dados mostram que ser casado ou viúvo aumenta o risco de IAM tendo, o viúvo, um componente de depressão e, o casado, o estresse associado á responsabilidade e aos fatores financeiros que envolvem sua condição. Além disso, quanto menor a renda familiar e o índice de escolaridade, maior o risco de IAM (Avezum, Piegas, \& Pereira, 2005; Avezum, Piegas, Pereira, Rossi Neto, \& Hoepfner, 2003).

Quanto aos FR psicossociais, são fortemente associados à DCV a depressão e o estresse com o aumento de risco de IAM para a população global em torno de 2,67 vezes, ultrapassando FR como HAS e DM. Este é o impacto para a população: a normalização de depressão e estresse reduziria 33\% dos casos de IAM no mundo (Avezum et al., 2004).

A diminuição da variabilidade da freqüência cardíaca é significativamente mais comum nos pacientes depressivos que nos não depressivos, dado confirmado angiograficamente e com eletrocardiografia dinâmica. Sendo assim, a depressão aumentaria a incidência das arritmias ventriculares pelo predomínio do Sistema Nervoso Simpático, descarregado através da conexão entre o córtex pré-frontal, a amígdala e o hipotálamo (Carney, Saunders, Freedlande, Stain, \& Rich, 1995).

A toda situação de estresse e ansiedade o organismo reage liberando catecolaminas (adrenalina e noradrenalina) e corticóides, seja por ação direta do sistema simpático, o qual coloca o organismo em estado de alerta, seja por ação indireta do Sistema Nervoso Autônomo sobre as glândulas suprarrenais. Essas catecolaminas e os corticóides aumentados no estresse produzem uma vasta série de alterações no organismo, como: elevação da freqüência cardíaca e da pressão arterial; aumento do débito cardíaco, do consumo de oxigênio e da excitabilidade cardíaca; entrada de sódio e saída de potássio e magnésio das células; lesão endotelial; vasoconstrição periférica; retenção de sódio e água; hemoconcentração; aumentos na adesividade plaquetária, coagulação sangüínea, glicose, ácido lático, ácidos graxos e do colesterol (Ballone, 2007). 
O estresse emocional pode precipitar arritmias ventriculares e/ou morte súbita, ao estimular vias serotoninérgicas no $\mathrm{SNC}$, as quais afetam fortemente o funcionamento cardiovascular (Jiang, Babyak, Krantz, Waugh, \& Blumenthal, 1996).

Entretanto, algumas pessoas reagem "cardiacamente" e outras não. De um modo geral e em graus variáveis, sempre há participação do sistema cardiovascular nas situações de estresse. Assim sendo, pode-se dizer que há uma sensibilidade especial do sistema cardiovascular às emoções. A palpitação que sentimos depois de um susto não significa que "sofremos" do coração, mas que nosso coração sofre com os sustos.

Depressão e ansiedade fatores associados à DCV (IAM) e, a combinação destes, agrava a situação aumentando em três vezes o risco de ocorrência do evento. O controle dos FR das principais formas de DCV (IAM e AVC) pode diminuir os dados. No Brasil, aqueles que afetam a adesão ao tratamento, como desconhecimento da doença, crenças, falta de apoio familiar, comorbidades de ordem psicológica / psiquiátrica, com campo vasto para investigação, ainda não foram devidamente estudados.

Fatores psicossociais devem ser considerados quanto à avaliação da condição de adesão do paciente às orientações médicas. Depressão e ansiedade merecem diagnóstico diferencial devido à debilidade gerada pela IC grave e as fantasias ligadas ao enxerto.

Observações científicas tem constatado que um dos principais fatores de proteção contra o IAM, e mesmo como favorecedor da recuperação dessa doença, tem sido o apoio emocional ao paciente oferecido pelos grupos de suporte social (Barefoot, Helms, Mark, Blumenthal, \& Califf, 1996).

As emoções estimulam ações que podem determinar padrões de atividade fisiológica, funcionando como base do comportamento adaptativo. Podem ser identificados fatores emocionais que ocorrem simultaneamente a arritmias cardíacas. Neste sentido, compreender como os fatores emocionais atuam sobre o desequilíbrio funcional do coração pode facilitar o 
desenvolvimento de estratégias terapêuticas mais eficazes em Cardiologia (Bonomo \& Araujo, 2009).

Quando se diz que as questões emocionais estão atreladas a qualquer outra patologia, não se quer dizer que elas sejam sempre causas de doenças orgânicas, mas que as emoções acompanham as outras doenças, quer como causa, como agravantes ou como conseqüência.

Diversos exames são solicitados muito antes do clínico procurar saber de qualquer componente emocional eventualmente associado ao estado atual do paciente. Está absolutamente certa essa tendência em procurar afastar causas orgânicas para as queixas do paciente, desde que o clínico não acredite, realmente, que a morte por IAM seja mais letal que a morte por suicídio (Ballone, 2007)

A instituição de saúde é um campo de trabalho onde as situações demandam a tomada de decisões por parte de seus membros e que, quase sempre, dizem respeito à vida de sujeitos humanos. No trabalho de uma equipe multidisciplinar a responsabilidade da decisão referente à melhor maneira de manejar o paciente e determinar os rumos do tratamento parece ser coletiva (Moretto, 2006).

Um dos fatores decisivos para o sucesso do tratamento é a consideração dos aspectos psicológicos do paciente: o enfermo deve estar minimamente ajustado para que possa cooperar com as orientações da equipe e ter amparo familiar e emocional consistentes.

Sendo o coração um órgão carregado de simbologia, fantasias que emergem com a indicação da cirurgia de TC podem se voltar à perda da vida, dos sentimentos, do centro da existência (Tamagnini, 2009).

Assim, faz-se necessária a construção de demanda a partir da Psicanálise exercida em instituições de saúde, ao examinar o paciente a em sua relação com seu sofrimento corporal e psíquico (Maluf, 2007). 
É a compreensão dos processos psíquicos desencadeados pela interação corpo - mente que permitirá a avaliação dos FR ligados à doença cardíaca.

Diante da confirmação de uma doença, inúmeras fantasias inconscientes podem surgir por se tratar de uma situação geradora de angústia e que sugere o restabelecimento de equilíbrio. Em se tratando de uma indicação a um transplante cardíaco, a incorporação de um novo coração poderá favorecer o surgimento de fantasias inconscientes específicas. A possibilidade de os fatores emocionais afetarem esta delicada situação deve ser incluída desde a compreensão de um diagnóstico até a instauração e progresso da doença.

A compreensão das reações emocionais do paciente diante do adoecer deve ser devidamente valorizada. A doença costuma ser estudada e entendida apenas pelo lado anatômico, clínico e sintomatológico. O que se pleiteia para o clínico é um enfoque mais generalista, através da compreensão da pessoa que vive sua doença.

A dinâmica psíquica do paciente cardiopata será avaliada / demonstrada com a identificação das relações objetais, comorbidades, aspectos psicossomáticos e fantasias inconscientes nos diferentes estágios de DCV. A hipótese é a de que a compreensão deste processo poderá favorecer no controle dos FR de ordem psicológica / psiquiátrica, necessário para a manutenção da adesão ao tratamento e cumprimento das orientações da equipe garantindo, assim, melhor prognóstico. 


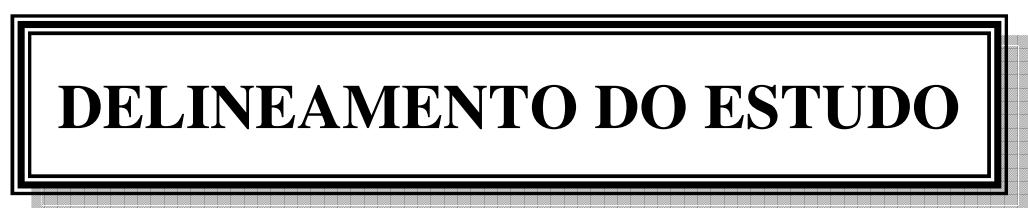




\section{DELINEAMENTO DO ESTUDO}

\section{$2.1 \quad$ JUSTIFICATIVA}

Fantasias inconscientes e relações objetais correspondentes às posições arcaicas do desenvolvimento são identificadas em pacientes cardiopatas graves, candidatas à cirurgia de transplante cardíaco. O funcionamento psíquico apresentado pode atuar como fator de risco, levando à intensa negação da condição clínica e conseqüente abandono do tratamento (Tamagnini, 2009). A hipótese que originou este estudo foi a de que a intensidade da doença cardiovascular pode estar relacionada a prejuízos no funcionamento psíquico, o que sugeriria atenção especial da equipe multidisciplinar e a instauração de psicoterapia para determinados grupos. Relações objetais persecutórias associadas a fantasias inconscientes de natureza arcaica em candidatos ao enxerto podem ser desfavoráveis à adaptação, atuando como fatores de risco na condição de IC grave.

Sendo o coração um órgão carregado de simbologia, foi aguçado o interesse em investigar a psicodinâmica dos pacientes com diferentes funcionalidades cardíacas (Classes Funcionais), a fim de identificar o sofrimento psíquico gerado em fases distintas de DCV.

Pretendeu-se, portanto, investigar a natureza da fantasia inconsciente e os processos psíquicos desencadeados em interação com os diferentes estágios de doença cardiovascular, especialmente de insuficiência cardíaca, e as peculiaridades destes grupos em relação a pacientes que não apresentaram evidência da doença e que procuraram por análise pessoal. A condição psicológica encontrada, além de requerer atenção do profissional de saúde mental, poderá ser discutida com a equipe, favorecendo a compreensão dos profissionais envolvidos em relação à psicodinâmica dos pacientes e de como os processos mentais podem atuar como fatores de risco e agravar a condição física atual. 


\subsection{OBJETIVOS}

\subsubsection{OBJETIVO PRINCIPAL}

Analisar os processos psíquicos desencadeados em pacientes cardiopatas nos diferentes estágios de DCV (especialmente de IC), identificando as particularidades psicodinâmicas de cada grupo em relação à pacientes sem evidência da doença.

\subsubsection{OBJETIVOS CO-PRINCIPAIS}

- Avaliar a natureza das relações objetais e das fantasias inconscientes em cardiopatas CF I ou II, CF III ou IV que não receberam indicação para o TC, CF III ou IV indicados à cirurgia de enxerto;

- Verificar os processos psicodinâmicos que podem levar a prejuízos no autocuidado e abandono do tratamento, atuando como FR para a doença (agravamento da condição clínica);

- Considerar os aspectos psicossomáticos nas diferentes classes funcionais;

- Sugerir um protocolo de avaliação psicodiagnóstica de base psicanalítica que permita ao profissional psicanalista dialogar com a equipe acerca dos processos mentais observados, sendo este conhecimento determinante de um prognóstico mais satisfatório quando considerado no tratamento da cardiopatia.

\subsection{MÉTODO}

Utilizou-se o método clínico de investigação para o desenvolvimento de uma pesquisa qualitativa, partindo de um estudo do tipo observacional. O material foi proveniente de 
entrevista clínica e aplicação do Teste de Relações Objetais (Phillipson, 1981). Os resultados foram discutidos à luz da teoria psicanalítica.

\subsubsection{PARTICIPANTES}

Participaram deste estudo pacientes sem evidência de DCV $(\mathrm{N}=10)$ e pacientes que apresentavam DCV, principalmente ICC $(\mathrm{N}=30)$, pertencentes a diferentes Classes Funcionais (NYHA). Foram divididos entre os seguintes grupos:

- Grupo A: DCV não evidente $(\mathrm{N}=10)$ - pacientes provenientes de clínica particular, que procuraram avaliação e tratamento em psicoterapia psicanalítica e que não apresentam evidência de DCV.

- Grupo B: CF I ou II: $(\mathrm{N}=10)$ - pacientes do ambulatório de IC da Faculdade de Medicina do ABC (FMABC), encaminhados pelo cardiologista responsável pelo ambulatório após consulta médica.

- Grupo C: CF III ou IV sem indicação para o TC: $(\mathrm{N}=13)$ - pacientes internados na enfermaria do Pronto Socorro Central de São Bernardo do Campo.

- Grupo D: CF III ou IV com indicação para o TC: $(\mathrm{N}=7)$ - mulheres que foram avaliadas e acompanhadas durante pesquisa anterior realizada no Instituto Dante Pazzanese de Cardiologia - IDPC, em São Paulo (Tamagnini, 2009).

\subsubsection{INSTRUMENTOS}

- Entrevista Clínica e emprego da escala AGF do DSM-IV (Associação Americana de Psiquiatria [APA], 2002).

- TRO - Teste de Relações Objetais de Phillipson (Phillipson, 1981). 


\subsubsection{CONSIDERAÇÕES SOBRE OS INSTRUMENTOS}

Após a definição dos sujeitos que participaram desta pesquisa e assinados os TCLE (Apêndice B), foram realizadas as entrevistas e aplicadas as lâminas selecionadas do TRO: A1(1), B3(4), AG(5), BG(10), C2(11) e Branca(13).

A entrevista clínica foi caracterizada por questões abertas e norteadoras, a fim de conduzir o paciente na direção dos objetivos propostos e visando um apanhado geral de informações para preencher os requisitos da escala AGF - DSM-IV (Anexo A). Pesquisas apontam para a importância no emprego de entrevista com questões norteadoras (semiestruturada) para a coleta de dados (Wengraf, 2001; Barriball, \& While, 1994; Bowling, 2001). Este instrumento é amplamente utilizado quando se têm objetivos definidos e pode ser empregado para a obtenção de dados quantitativos ou qualitativos.

A Avaliação Global do Funcionamento, rastreada pela escala AGF, constitui o quinto eixo no sistema DSM e seu propósito é permitir um julgamento acerca do nível global de funcionamento psicológico, social e ocupacional do indivíduo, excluindo as limitações físicas da avaliação (Söderberg, Tungström, \& Armelius, 2005). É considerado o funcionamento psicológico num contínuo hipotético de saúde / doença, com pontuação relativa ao período atual, variando de zero a 100, com intervalos de 10 pontos. Desse modo, pontuações elevadas são interpretadas como funcionamento social, psicológico e ocupacional satisfatório, enquanto que casos com pontuações inferiores a 50 indicam importante severidade dos sintomas e prejuízos quanto à competência social (Associação Americana de Psiquiatria [APA], 2002).

O TRO é uma técnica projetiva, elaborada por Phillipson em 1955 com base na Teoria das Relações Objetais de Melanie Klein, composto por treze lâminas - A1(1), A2(2), C3(3), B3(4), AG(5), B1(6), CG(7), A3(8), B2(9), BG(10), C2(11), C1(12) e Branca(13). Os participantes foram convidados a contar histórias a partir do que observavam nas lâminas e a 
análise auxiliou na compreensão de sua psicodinâmica. A percepção das relações pessoais diz sobre a conduta de um indivíduo em determinada situação: o mundo interno das relações objetais determina as relações que este estabelece com o mundo externo (Phillipson, 1981).

As lâminas que foram selecionadas para análise, relevantes para o estudo (A1, B3, AG, BG, C2, Branca), estimulam os seguintes indicadores (Phillipson, 1981; Ocampo, Arzeno, \& Grassano, 1981; Arzeno, 1983; Rosa, 1995):

- A1(1): Verifica como o paciente reage frente a uma nova situação. É recomendada em estudos que avaliam o prognóstico. Fornece elementos para investigar como o paciente vive a situação de psicodiagnóstico e como estabelece a relação transferencial (relações objetais primitivas de dependência). Coloca-o diante da solidão e sugere uma situação regressiva, ameaçadora para o ego. Podem aparecer fantasias vinculadas à doença e cura, além de aspectos adaptativos ou patológicos. Indica o olhar para o que está dentro em relação com o que há fora (mundo interno e externo);

- B3(4): O conteúdo de realidade é precário e o ambiente se torna menos acolhedor. Apresenta uma situação triangular, com um par claramente unido e um terceiro afastado, que pode ser admitido como excluído / incluído ou negado (distorção perceptual devido a intensa ansiedade persecutória);

- AG(5): Explora angústia depressiva e a capacidade de tolerar a destruição de objetos e elaborar perdas. Indica como o paciente lida com lutos reais ou fantasiados e, se não sente depressivamente o conteúdo da lâmina, pode demonstrar ansiedade confusional, idealização e perseguição. Diferencia um ego comprometido de um adaptado (elaborações melancólicas ou maníacas);

- BG(10): Faz referência ao grupo, com um dos indivíduos em exclusão espacial. Explora sentimentos de solidão e exclusão, além de aceitação, rejeição e indiferença diante do 
outro. Possibilita a compreensão da dinâmica do paciente em relação a uma possível alta e recursos que dispõe para reintegração ao meio;

- C2(11): Induz a pensar em situações de morte, doença e velhice com o personagem que aparece na cama. Estimula fantasias de perda objetal, sentimentos depressivos, fantasias reparatórias ou destrutivas / ameaçadoras (referentes ao personagem que se aproxima), que levam a elaboração depressiva ou maníaca. Indica se o luto é originado por situações passadas, presente ou futuras (projetos renunciados). Quando as ansiedades são excessivas, aparecem fenômenos confusionais. Sugere um estímulo que implica em tolerar a morte ou a doença do objeto,

- Branca(13): Carência total de estímulo visual. Funciona como controle para as anteriores e explora a relação transferencial que foi estabelecida. Permite a criação de uma história, chave para a formulação do prognóstico, a partir da elaboração de um projeto existencial. Indica uma situação de separação que serve para compreender os afetos que foram mobilizados e as possibilidades de recuperação diante de perdas, supondo elaborações depressivas (reconhecer o sofrimento, que implica em aceitar ajuda e um tratamento) ou maníacas (negando condição atual e desvalorizando o processo).

A avaliação das lâminas do TRO seguiu os critérios de análise do Sistema Tensional Inconsciente Dominante (STID) concentrado na exploração da tríade metapsicológica formada por desejos inconscientes, sentimentos (medos / ansiedades) e mecanismos de defesa, para avaliar as relações objetais predominantes (Phillipson, 1981; Rosa, 1995). Assim, procurou-se verificar o STID segundo o modelo das Relações Objetais de Melanie Klein, de acordo com a teoria das posições.

O material proveniente da entrevista clínica e da análise do TRO permitiu as inferências acerca do funcionamento mental dos pacientes estudados. 


\subsubsection{PROCEDIMENTO}

Os instrumentos foram aplicados em 33 pacientes provenientes dos grupos A, B e C. e os resultados somados / discutidos com os dados encontrados em pesquisa anterior, com pacientes candidatas ao TC (Tamagnini, 2009), que compõem o grupo D (CF III ou IV com indicação para o TC).

Os componentes dos grupos A, B e C foram selecionados a partir de amostras por conveniência: os pacientes do grupo A de acordo com a sequência de elaboração do psicodiagnóstico; os pacientes do grupo B após consulta médica e encaminhamento, no ambulatório de Insuficiência Cardíaca da FMABC e, os pacientes do grupo C, com base nos prontuários e durante o período de internação no Pronto Socorro Central de São Bernardo do Campo.

Foram realizados de 1 a 2 encontros para a coleta do material. Os pacientes foram abordados individualmente. Inicialmente, receberam informações sobre os objetivos do estudo e assinaram o Termo de Consentimento Livre e esclarecido (TCLE), elaborado a partir das instruções da Resolução 196 do Documento das Américas - ANVISA, para que autorizassem a participação. O TCLE garantiu o sigilo profissional e o anonimato dos participantes, forneceu os esclarecimentos necessários quanto aos objetivos, procedimentos e instrumentos que seriam utilizados no estudo, permitiu a decisão de participação voluntária e informou sobre a publicação dos resultados, assegurando o cumprimento de manter o anonimato dos mesmos durante todo o processo de elaboração da tese ou de artigos científicos (Apêndice B). Durante a avaliação, os pacientes receberam orientações e encaminhamentos. 


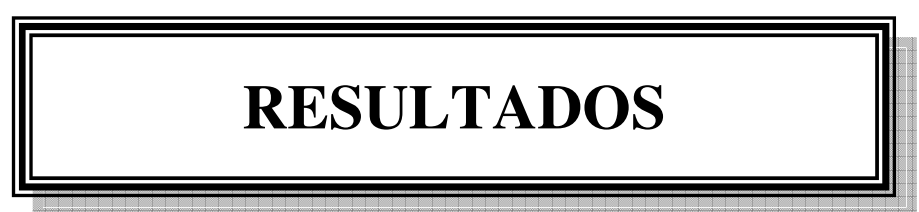




\section{RESULTADOS}

\subsection{APRESENTAÇÃO}

\section{- PARTE I - ANÁLISE E INTERPRETAÇÃO DO TRO E AVALIAÇÃO GLOBAL DO FUNCIONAMENTO}

A análise e interpretação do TRO seguiu os parâmetros do Protocolo de Análise e Interpretação do Teste de Relações Objetais de Phillipson (Apêndice A). Foram descritos os aspectos manifestos, desejos inconscientes, medos / ansiedades, mecanismos de defesa e fantasias inconscientes dos pacientes que compõem os grupos A, B, C e D.

A entrevista clínica possibilitou a análise da psicodinâmica dos pacientes estudados, sendo utilizada como base para a interpretação das histórias do TRO e da Avaliação Global do Funcionamento - Eixo V.

\section{- PARTE II - RELAÇÕES OBJETAIS E FANTASIAS INCONSCIENTES PREDOMINANTES}

Apresentação das relações de objeto e das fantasias inconscientes dominantes nos grupos estudados - STID e exposição da pontuação média / grupo no TRO e AGF. 


\subsection{RESULTADOS - PARTE I}

\section{GRUPO A}

\section{PACIENTE 1}

Idade: 22 anos sexo: masculino

HD: T. Pânico (ansiedade paroxística episódica) / ansiedade generalizada.

- ANÁLISE E INTERPRETAÇÃO DO TRO:

Quadro 1. Avaliação das lâminas - paciente 1 do grupo A:

\begin{tabular}{|c|c|c|c|c|c|}
\hline & \multicolumn{3}{|c|}{ STID } & \multirow{2}{*}{$\begin{array}{c}\text { Fantasia } \\
\text { Inconsciente } \\
\text { Dominante }\end{array}$} & \multirow[b]{2}{*}{ Pontos } \\
\hline & $\begin{array}{c}\text { Desejos } \\
\text { Inconscientes }\end{array}$ & $\begin{array}{c}\text { Medos / } \\
\text { Ansiedades }\end{array}$ & $\begin{array}{l}\text { Mecanismos } \\
\text { de Defesa }\end{array}$ & & \\
\hline A1 & $\begin{array}{c}\text { Paralisação, } \\
\text { proteger do } \\
\text { aniquilamento }\end{array}$ & $\begin{array}{l}\text { Persecutoriedade, } \\
\text { medo do } \\
\text { aniquilamento }\end{array}$ & $\begin{array}{l}\text { Negação, } \\
\text { paralisação }\end{array}$ & Aniquilamento & 3 \\
\hline $\mathrm{AG}$ & $\begin{array}{c}\text { Paralisar } \\
\text { objeto ou self }\end{array}$ & $\begin{array}{c}\text { Angústia, } \\
\text { ansiedade } \\
\text { confusional } \\
\end{array}$ & $\begin{array}{c}\text { Idealização, } \\
\text { controle } \\
\text { onipotente }\end{array}$ & Paralisação & $2-3$ \\
\hline B3 & $\begin{array}{c}\text { Separar } \\
\text { objeto bom e } \\
\text { mau, } \\
\text { reparação }\end{array}$ & $\begin{array}{l}\text { Ambivalência, } \\
\text { desvalorização, } \\
\text { isolamento }\end{array}$ & $\begin{array}{c}\text { Identificação } \\
\text { projetiva e } \\
\text { adesiva }\end{array}$ & $\begin{array}{l}\text { Destruição do } \\
\text { Objeto }\end{array}$ & $2-3$ \\
\hline BG & $\begin{array}{l}\text { Fusão com o } \\
\text { objeto amado }\end{array}$ & $\begin{array}{l}\text { Autodesvalorização } \\
\text { isolamento }\end{array}$ & $\begin{array}{c}\text { Identificação } \\
\text { projetiva }\end{array}$ & $\begin{array}{l}\text { Destruição do } \\
\text { Objeto }\end{array}$ & 3 \\
\hline $\mathrm{C} 2$ & $\begin{array}{c}\text { Paralisar o } \\
\text { objeto ou self }\end{array}$ & $\begin{array}{l}\text { Perseguição, } \\
\text { angústia } \\
\text { persecutória }\end{array}$ & $\begin{array}{c}\text { Negação / } \\
\text { escotomização }\end{array}$ & $\begin{array}{l}\text { Mutilação, } \\
\text { retaliação }\end{array}$ & 3 \\
\hline $\mathrm{Br}$ & Reparação & $\begin{array}{l}\text { Angústia } \\
\text { depressiva }\end{array}$ & $\begin{array}{l}\text { Introjeção de } \\
\text { bons objetos }\end{array}$ & Separação & 5 \\
\hline & & & & & $\begin{array}{c}\mathrm{N}=18-20 \\
\text { Média }=3-4\end{array}$ \\
\hline
\end{tabular}

Aspectos manifestos: homem, local tenebroso, obscuro e "do mal" (A1); monges e religiosos orando, conteúdo de realidade negado - precária descrição de cenário (AG); pessoa, 
conteúdo de realidade negado (B3); turistas que não se relacionam, Coliseu, local histórico (BG); criminoso armado, cena de filme de assassinato (C2); seres angelicais (Branca).

Análise: apresenta luto por objetos primários e projetos existenciais (atuais), destruição. Presença de algumas defesas maníacas com pouca capacidade de reparação do objeto destruído.

Ignora partes dos cenários e personagens comumente visualizados (AG), negando situação apresentada na lâmina. Luto também pela perda dos pais da infância (B3).

Freqüentes sentimentos de solidão e abandono são observados ao longo do exame. Medo intenso verificado (medo de progredir, crescer, expandir e morrer). Mantém atitude regredida.

Utiliza lâmina Branca para tentar reparar destruição, porém se remete à criação de seres inanimados, demonstrando distanciamento afetivo na história narrada. Ao final, nota-se angústia depressiva durante a narração de um possível recomeço e introjeção de bons objetos.

Persecutoriedade: questiona repetidas vezes acerca da atitude de outras pessoas em relação ao TRO, como reagem frente às lâminas, o que dizem. Surpreende-se com dificuldade encontrada e se angustia, referindo ser este um "teste perigoso, que necessita de cuidados".

Estabelece relações de objeto características da posição esquizoparanóide e depressiva (oscilações entre relações de objeto parciais e totais).

\section{- AVALIAÇÃO MULTIAXIAL - EIXO V - DSM-IV}

Escala de Avaliação Global do Funcionamento (AGF) - Pontuação: 56.

Sintomas moderados, como ataques de pânico ocasionais, com alguma dificuldade no funcionamento social (freqüentes conflitos familiares). 


\section{PACIENTE 2}

Idade: 23 anos Sexo: feminino

HD: T. Humor - T. Misto Ansioso e Depressivo.

\section{- ANÁLISE E INTERPRETAÇÃO DO TRO:}

Quadro 2. Avaliação das lâminas - paciente 2 do grupo A

\begin{tabular}{|c|c|c|c|c|c|}
\hline & \multicolumn{3}{|c|}{ STID } & \multirow{2}{*}{$\begin{array}{c}\text { Fantasia } \\
\text { Inconsciente } \\
\text { Dominante }\end{array}$} & \multirow[b]{2}{*}{ Pontos } \\
\hline & $\begin{array}{c}\text { Desejos } \\
\text { Inconscientes }\end{array}$ & $\begin{array}{c}\text { Medos / } \\
\text { Ansiedades }\end{array}$ & $\begin{array}{l}\text { Mecanismos } \\
\text { de Defesa }\end{array}$ & & \\
\hline A1 & $\begin{array}{c}\text { Proteger do } \\
\text { aniquilamento }\end{array}$ & $\begin{array}{l}\text { Angústia, luto } \\
\text { pela destruição } \\
\text { do objeto }\end{array}$ & $\begin{array}{l}\text { Introjeção do } \\
\text { bom objeto }\end{array}$ & Perda, separação & 5 \\
\hline $\mathrm{AG}$ & $\begin{array}{c}\text { Proteger do } \\
\text { aniquilamento }\end{array}$ & $\begin{array}{c}\text { Angústia } \\
\text { depressiva, luto e } \\
\text { morte }\end{array}$ & $\begin{array}{l}\text { Controle de } \\
\text { objetos }\end{array}$ & Fragmentação & $4-5$ \\
\hline B3 & $\begin{array}{c}\text { Separar } \\
\text { objetos bons e } \\
\text { maus }\end{array}$ & $\begin{array}{c}\text { Angústia } \\
\text { depressiva, culpa }\end{array}$ & $\begin{array}{l}\text { Introjeção, } \\
\text { reparação }\end{array}$ & Separação & $5-6$ \\
\hline $\mathrm{BG}$ & $\begin{array}{l}\text { Reparação, } \\
\text { proteção }\end{array}$ & $\begin{array}{c}\text { Solidão, } \\
\text { aniquilamento }\end{array}$ & $\begin{array}{l}\text { Reparação } \\
\text { maníaca }\end{array}$ & $\begin{array}{l}\text { Aniquilamento, } \\
\text { destruição }\end{array}$ & $6-7$ \\
\hline $\mathrm{C} 2$ & $\begin{array}{l}\text { Separar } \\
\text { objetos }\end{array}$ & $\begin{array}{l}\text { Solidão, } \\
\text { abandono }\end{array}$ & $\begin{array}{c}\text { Negação, } \\
\text { controle } \\
\text { onipotente } \\
\end{array}$ & Separação & $5-6$ \\
\hline $\mathrm{Br}$ & Reparação & $\begin{array}{l}\text { Luto pela } \\
\text { destruiçãa }\end{array}$ & $\begin{array}{l}\text { Reparação } \\
\text { maníaca }\end{array}$ & Elaborar luto & $5-6$ \\
\hline & & & & & $\begin{array}{c}\mathrm{N}=30-35 \\
\text { Média }=5-6\end{array}$ \\
\hline
\end{tabular}

Aspectos manifestos: avô, espírito, casa da avó, sala, corredor (A1); mortos, limbo e céu (AG); casal, espião, conteúdo de realidade negado (B3); crianças, escolares, escola (BG); família - mãe e filho, casa, quarto (C2); nenhum aspecto manifesto (Branca).

Análise: Mostra-se mobilizada com a situação de teste (A1). Remonta cenas acompanhadas de angústias de reparação, luto pela destruição do objeto. 
Sentimento de inveja referente ao casal relatado em situação triangular (B3), inicialmente com caráter destrutivo, porém, ao final da narrativa, repara afirmando não se tratar de destruição e sim de algo que gostaria de ter. Intitula a história desta lâmina como "Inveja Branca".

Ansiedade e medo referente à morte de si e do outro. Angústia quanto ao momento pós-morte (AG). Sentimento de solidão por vezes identificado nas narrativas. Ao final das histórias contadas, repara a destruição feita aos objetos e introjeta os bons. Surgem sentimentos de angústia e culpa pela destruição inicial.

Mecanismo de negação diante do conteúdo de abandono mobilizado em C2.

Fantasia inconsciente dominante de perda e elaboração do luto vislumbrada na última lâmina apresentada (Branca) e identificada a reparação maníaca como esforço defensivo (mecanismo de defesa) empregado.

Considera personagens e cenas. Estabelece relações de objeto totais com alguma ambivalência (quando destrói, repara), típica dos Transtornos Afetivos (posição depressiva).

\section{- AVALIAÇÃO MULTIAXIAL - EIXO V - DSM-IV}

Escala de Avaliação Global do Funcionamento (AGF) - Pontuação: 80

De acordo com a pontuação atribuída a partir da AGF, trata-se de sintomas temporários e reações congruentes a estressores psicossociais. Não mais do que leve prejuízo no funcionamento social, ocupacional ou escolar. Apresenta alguns sintomas de ansiedade na execução de tarefas cotidianas e rebaixamento de concentração em situações desafiadoras. No entanto, mantém desempenho satisfatório diante da dificuldade. Declínios ocasionais levam a prejuízos no sono e alimentação. Importante capacidade adaptativa, busca controle dos sintomas de ansiedade e melhora de qualidade de vida em psicoterapia. 


\section{PACIENTE 3}

Idade: 37 anos sexo: feminino

HD: T. Depressivo Recorrente, episódio atual grave sem sintomas psicóticos.

\section{- ANÁLISE E INTERPRETAÇÃO DO TRO:}

Quadro 3. Avaliação das lâminas - paciente 3 do grupo A

\begin{tabular}{|c|c|c|c|c|c|}
\hline & \multicolumn{3}{|c|}{ STID } & \multirow{2}{*}{$\begin{array}{c}\text { Fantasia } \\
\text { Inconsciente } \\
\text { Dominante }\end{array}$} & \multirow[b]{2}{*}{ Pontos } \\
\hline & $\begin{array}{c}\text { Desejos } \\
\text { Inconscientes }\end{array}$ & $\begin{array}{c}\text { Medos / } \\
\text { Ansiedades }\end{array}$ & $\begin{array}{c}\text { Mecanismos } \\
\text { de Defesa }\end{array}$ & & \\
\hline A1 & $\begin{array}{l}\text { Proteger do } \\
\text { aniquilamento }\end{array}$ & $\begin{array}{c}\text { Medo de } \\
\text { progredir, } \\
\text { morrer, solidão }\end{array}$ & $\begin{array}{l}\text { Controle de } \\
\text { objetos, } \\
\text { idealização }\end{array}$ & $\begin{array}{l}\text { Solidão, } \\
\text { abandono }\end{array}$ & $5-6$ \\
\hline AG & $\begin{array}{c}\text { Paralisar o } \\
\text { objeto ou self }\end{array}$ & $\begin{array}{l}\text { Medo de } \\
\text { progredir, } \\
\text { morrer }\end{array}$ & $\begin{array}{c}\text { Negação - } \\
\text { escotomização, } \\
\text { controle } \\
\text { onipotente }\end{array}$ & Perda, morte & $2-3$ \\
\hline B3 & $\begin{array}{c}\text { Separação de } \\
\text { objetos }\end{array}$ & $\begin{array}{l}\text { Luto pela } \\
\text { destruição }\end{array}$ & $\begin{array}{c}\text { Identificação } \\
\text { projetiva, } \\
\text { negação }\end{array}$ & $\begin{array}{l}\text { Destruição, } \\
\text { morte }\end{array}$ & $3-4$ \\
\hline BG & $\begin{array}{l}\text { Proteger do } \\
\text { aniquilamento }\end{array}$ & $\begin{array}{c}\text { Auto- } \\
\text { desvalorização, } \\
\text { medo, solidão }\end{array}$ & $\begin{array}{c}\text { Reparação } \\
\text { maníaca }\end{array}$ & Recuperação & $4-5$ \\
\hline $\mathrm{C} 2$ & $\begin{array}{c}\text { Proteger do } \\
\text { aniquilamento }\end{array}$ & $\begin{array}{l}\text { Solidão, } \\
\text { isolamento }\end{array}$ & $\begin{array}{l}\text { Introjeção do } \\
\text { bom objeto }\end{array}$ & Separação & $3-4$ \\
\hline $\mathrm{Br}$ & $\begin{array}{l}\text { Reparação do } \\
\text { objeto }\end{array}$ & $\begin{array}{l}\text { Melancolia, } \\
\text { ambivalência }\end{array}$ & $\begin{array}{l}\text { Idealização, } \\
\text { controle }\end{array}$ & Separação, luto & $4-5$ \\
\hline & & & & & $\begin{array}{c}\mathrm{N}=21-27 \\
\text { Média }=4-4,5\end{array}$ \\
\hline
\end{tabular}

Aspectos manifestos: homem, adulto, natureza (A1); pessoas e mortos, nega conteúdo de realidade (AG); pai, criança, espião, casa familiar, quarto (B3); mulher, adultos, conteúdo de realidade negado (BG); idosa, quarto com cama de solteiro (C2); nenhum aspecto manifesto (Branca). 
Análise: medo da solidão intensificado atualmente. Busca por proteção do aniquilamento, preservação de saúde mental (A1). Acredita que encontrará serenidade em ambiente conhecido, familiar (natureza). Busca separação de objetos (colocar a criança na cama) o que intensifica sentimento de solidão citado anteriormente (B3). Relata situação triangular mantendo o pai junto à criança e alguém espiando esta relação, porém, repara em seguida apontando cuidados importantes dispensados pelo pai (objeto total).

Persecutoriedade relacionada ao medo de destruição e morte (angústia persecutória visualizada na narrativa do "juízo final” em AG. Morte, aqui, interpretada como perda de uma condição anterior. Autodesvalorização observada. Defende-se do sentimento de solidão com uma "solidão acompanhada" (título em BG), na qual ainda é vista, talvez em análise.

Nega personagem na cama em C2 e caracteriza o "estar só" como algo tranqüilo e suportável. Melancólica ao identificar que os estímulos nas cinco primeiras lâminas apresentadas originaram enredos difíceis, percebendo que poderia colorir as cenas, reparar a destruição (Branca). Afirmação de que o momento atual a levou a narrar histórias tristes e sombrias e que, futuramente, "poderão não ser tristes assim”.

Tendência adaptativa, paciente oscila entre relações de objeto parciais e totais (predominam totais - posição depressiva). Sentimento de culpa verificado durante o exame.

\section{- AVALIAÇÃO MULTIAXIAL - EIXO V - DSM-IV}

Escala de Avaliação Global do Funcionamento (AGF) - Pontuação: 55

A análise das entrevistas iniciais indica a presença de sintomas moderados, oscilam entre depressivos e ansiosos. Persecutoriedade, com capacidade de reparar destruição do objeto. Momentos freqüentes de intensa angústia congruente à situação atual caracterizada por importantes mudanças pessoais (relacionamento) e profissionais. 


\section{PACIENTE 4}

Idade: 21 anos sexo: feminino

HD: Ansiedade generalizada com sintomas obsessivos.

\section{- ANÁLISE E INTERPRETAÇÃO DO TRO:}

Quadro 4. Avaliação das lâminas - paciente 4 do grupo A

\begin{tabular}{|c|c|c|c|c|c|}
\hline & \multicolumn{3}{|c|}{ STID } & \multirow{2}{*}{$\begin{array}{c}\text { Fantasia } \\
\text { Inconsciente } \\
\text { Dominante }\end{array}$} & \multirow[b]{2}{*}{ Pontos } \\
\hline & $\begin{array}{c}\text { Desejos } \\
\text { Inconscientes }\end{array}$ & $\begin{array}{c}\text { Medos / } \\
\text { Ansiedades }\end{array}$ & $\begin{array}{l}\text { Mecanismos } \\
\text { de Defesa }\end{array}$ & & \\
\hline A1 & $\begin{array}{l}\text { Separar objeto } \\
\text { bom e mau, } \\
\text { proteger } \\
\text { aniquilamento }\end{array}$ & $\begin{array}{l}\text { Angústia, medo } \\
\text { do aniquilamento }\end{array}$ & $\begin{array}{l}\text { Reparação } \\
\text { maníaca }\end{array}$ & $\begin{array}{l}\text { Morte, perda e } \\
\text { elaboração do } \\
\text { luto }\end{array}$ & 4 \\
\hline $\mathrm{AG}$ & $\begin{array}{c}\text { Paralisar o } \\
\text { objeto ou self }\end{array}$ & $\begin{array}{l}\text { Ambivalência, } \\
\text { medo } \\
\text { aniquilamento }\end{array}$ & $\begin{array}{c}\text { Idealização, } \\
\text { negação - } \\
\text { escotomização }\end{array}$ & $\begin{array}{l}\text { Desaparecimento, } \\
\text { morte }\end{array}$ & $3-4$ \\
\hline B3 & $\begin{array}{c}\text { Proteger do } \\
\text { aniquilamento }\end{array}$ & $\begin{array}{c}\text { Angústia, } \\
\text { persecutoriedade, } \\
\text { aniquilamento }\end{array}$ & Reparação & Aniquilamento & 5 \\
\hline BG & $\begin{array}{c}\text { Proteger do } \\
\text { aniquilamento }\end{array}$ & Persecutoriedade & $\begin{array}{c}\text { Negação - } \\
\text { escotomização, } \\
\text { controle }\end{array}$ & $\begin{array}{l}\text { Destruição, } \\
\text { fragmentação }\end{array}$ & 4 \\
\hline $\mathrm{C} 2$ & $\begin{array}{l}\text { Separar objeto } \\
\text { bom e mau }\end{array}$ & $\begin{array}{c}\text { Medo, } \\
\text { perseguição }\end{array}$ & $\begin{array}{l}\text { Desaparecimen } \\
\text { to, clivagem }\end{array}$ & Aniquilamento & 3 \\
\hline $\mathrm{Br}$ & $\begin{array}{l}\text { Separar objeto } \\
\text { bom e mau, } \\
\text { restaurar } \\
\text { objetos }\end{array}$ & $\begin{array}{c}\text { Ambivalência } \\
\text { (aspectos bons e } \\
\text { maus) }\end{array}$ & $\begin{array}{l}\text { Reparação } \\
\text { maníaca } \\
\text { angústia e } \\
\text { culpa) }\end{array}$ & $\begin{array}{c}\text { Perda e } \\
\text { elaboração do } \\
\text { luto }\end{array}$ & 5 \\
\hline & & & & & $\begin{array}{l}\mathrm{N}=24-25 \\
\text { Média }=4\end{array}$ \\
\hline
\end{tabular}

Aspectos manifestos: espíritos, homem, criança, céu, terra, vale com cachoeira (A1); homem, viajante, três marcianos, deserto, árvore, fenda intergaláctica (AG); casal, amantes, aldeão, escola primária, África, hospital (B3); alunos, escola (BG); avó, neta, quarto, casa (C2); balões (Branca). 
Análise: intenso sentimento de solidão em A1, narra criança angustiada aguardando explicações referentes à morte de sua mãe (abandono), aspectos de morte e luto durante a transição céu - terra, com ambivalência. Repara deixando a criança feliz e o homem indo para o céu após completar sua missão.

Fantasia de aniquilamento (angústia em B3), nega situação triangular apesar de impedir o progresso do casal com destrutividade. Reparação identificada quando se mostra capaz de vencer persecutoriedade (capacidade de enfrentamento) e aceita o casal.

Elaboração maníaca com fantasia inconsciente dominante de desaparecimento / destruição do self, seguida de idealização onipotente referente a "um mundo sem sofrimento" em AG, com a narrativa de personagens que conseguem superar adversidades. Culpa persecutória, confusão e sentimento de solidão. Faz referência ao grupo (BG) identificando um aluno isolada, confirmando sentimento de solidão diante do grupo (exclusão, destruição), corroborando com informações coletadas na entrevista (medo do aniquilamento gera isolamento, "prefere ser ele mesmo", não se insere). Na tentativa de separar objetos bons e maus, o self desaparece (C2), renunciando aos projetos existenciais, negando fantasias reparatórias (nega personagem, geralmente citado, que se aproxima para ajudar, cuidar). São mobilizados afetos e sentimentos ambivalentes na última lâmina, com possibilidade de recuperação / reparação, pressupondo condições para elaboração depressiva como prognóstico. Estabelece relações de objeto parciais e totais com possibilidade de reparação em situações de destruição. Mantém equilíbrio podendo conquistar relações positivas.

\section{- AVALIAÇÃO MULTIAXIAL - EIXO V - DSM-IV}

Escala de Avaliação Global do Funcionamento (AGF) - Pontuação: 55

Apresenta sintomas moderados, dificuldades no tratamento com o outro (grupo), certa destrutividade, mas com capacidade de reparação. 


\section{PACIENTE 5}

Idade: 19 anos sexo: feminino

HD: T. misto ansioso e depressivo / T. Pânico (ansiedade paroxística episódica) / T.

Obsessivo compulsivo

- ANÁLISE E INTERPRETAÇÃO DO TRO:

Quadro 5. Avaliação das lâminas - paciente 5 do grupo A

\begin{tabular}{|c|c|c|c|c|c|}
\hline & \multicolumn{3}{|c|}{ STID } & \multirow{2}{*}{$\begin{array}{c}\text { Fantasia } \\
\text { Inconsciente } \\
\text { Dominante }\end{array}$} & \multirow[b]{2}{*}{ Pontos } \\
\hline & $\begin{array}{c}\text { Desejos } \\
\text { Inconscientes }\end{array}$ & $\begin{array}{c}\text { Medos / } \\
\text { Ansiedades }\end{array}$ & $\begin{array}{l}\text { Mecanismos } \\
\text { de Defesa }\end{array}$ & & \\
\hline A1 & $\begin{array}{c}\text { Proteger do } \\
\text { aniquilamento }\end{array}$ & $\begin{array}{c}\text { Medo } \\
\text { aniquilamento }\end{array}$ & $\begin{array}{l}\text { Introjeção do bom } \\
\text { objeto }\end{array}$ & $\begin{array}{c}\text { Perda e } \\
\text { elaboração do } \\
\text { luto }\end{array}$ & 5 \\
\hline $\mathrm{AG}$ & $\begin{array}{c}\text { Paralisar o } \\
\text { objeto ou self }\end{array}$ & $\begin{array}{l}\text { Medo do } \\
\text { aniquilamento, de } \\
\text { progredir }\end{array}$ & $\begin{array}{c}\text { Desaparecimento, } \\
\text { identificação } \\
\text { projetiva }\end{array}$ & $\begin{array}{l}\text { Morte, perda, } \\
\text { desaparecer }\end{array}$ & 3 \\
\hline B3 & $\begin{array}{l}\text { Fusão com o } \\
\text { objeto, } \\
\text { paralisação }\end{array}$ & $\begin{array}{l}\text { Persecutoriedade, } \\
\text { inveja, medo de } \\
\text { progredir }\end{array}$ & $\begin{array}{c}\text { Negação, } \\
\text { identificação } \\
\text { projetiva, }\end{array}$ & $\begin{array}{l}\text { Destruição, } \\
\text { perda }\end{array}$ & 3 \\
\hline BG & $\begin{array}{c}\text { Proteger do } \\
\text { aniquilamento }\end{array}$ & $\begin{array}{c}\text { Angústia } \\
\text { persecutória, } \\
\text { auto- } \\
\text { desvalorização }\end{array}$ & $\begin{array}{l}\text { Introjeção do bom } \\
\text { objeto, reparação }\end{array}$ & $\begin{array}{l}\text { Separação, } \\
\text { destruição }\end{array}$ & $4-5$ \\
\hline $\mathrm{C} 2$ & $\begin{array}{l}\text { Separar objeto } \\
\text { bom e mau }\end{array}$ & $\begin{array}{l}\text { Angústia, } \\
\text { persecutoriedade }\end{array}$ & $\begin{array}{l}\text { Paralisação, } \\
\text { introjeção, } \\
\text { reparação }\end{array}$ & $\begin{array}{l}\text { Destruição, } \\
\text { perda }\end{array}$ & 5 \\
\hline $\mathrm{Br}$ & $\begin{array}{c}\text { Restaurar } \\
\text { objetos }\end{array}$ & $\begin{array}{l}\text { Angústia } \\
\text { depressiva }\end{array}$ & $\begin{array}{l}\text { Introjeção do } \\
\text { objeto bom, } \\
\text { reparação }\end{array}$ & $\begin{array}{c}\text { Perda e } \\
\text { elaboração do } \\
\text { luto } \\
\end{array}$ & $5-6$ \\
\hline & & & & & $\begin{array}{l}\mathrm{N}=25-27 \\
\text { Média }=4-4,5\end{array}$ \\
\hline
\end{tabular}

Aspectos manifestos: homem, cachoeira, peixes, cão, névoa (A1); soldados, mortos, pessoa, nevoeiro de guerra (AG); casal, conteúdo de realidade negado (B3); pessoa, grupo de 
pessoas, conteúdo de realidade negado (BG); tia, paciente, quarto, computador $(\mathrm{C} 2)$; apagador e giz (Branca).

Análise: relação transferencial estabelecida com a inclusão de um amigo que acompanha o homem solitário e triste em A1. Quando sofre, olha para "dentro" em atitude reflexiva, porém não deixa de se relacionar com o mundo exterior. Nega situação triangular demonstrando temor às identificações projetivas e dificuldade para reintrojeção (intensa ansiedade persecutória em B3).

Impossibilidade de elaborar situações de perda com culpa persecutória, apesar de vislumbrar aspectos destruídos como reparadores (AG). Embora mantenha posição de isolamento diante do grupo, com sentimento de rejeição e sofrimento em situação relatada de bullying (BG), mostra recursos internos para superação e capacidade de tolerância (encarar o futuro), escolhendo a opção "vai superar a adversidade” após ambivalência.

Culpa seguida por capacidade de elaboração depressiva ao reparar dano causado inicialmente (C2): aproximação com objeto morto favoreceu a elaboração da perda.

Possibilidade de reorganização do mundo interno com manutenção das "coisas que estão fora de lugar” (Branca): consciência do que é caótico, repara destruição com um “apagador e giz” para reescrever história de vida.

Relações de objeto totais e parciais, capacidade de reparar destruição. Equilíbrio mantido com liberdade para relações positivas, tendência adaptativa.

\section{- AVALIAÇÃO MULTIAXIAL - EIXO V - DSM-IV}

Escala de Avaliação Global do Funcionamento (AGF) - Pontuação: 61

Alguns sintomas persistem com dificuldades no funcionamento social. Certa agressividade: destrói objeto amado, porém apresenta recursos para reparação e elaboração depressiva. 


\section{PACIENTE 6}

Idade: 23 anos sexo: feminino

HD: T. misto ansioso e depressivo.

\section{- ANÁLISE E INTERPRETAÇÃO DO TRO:}

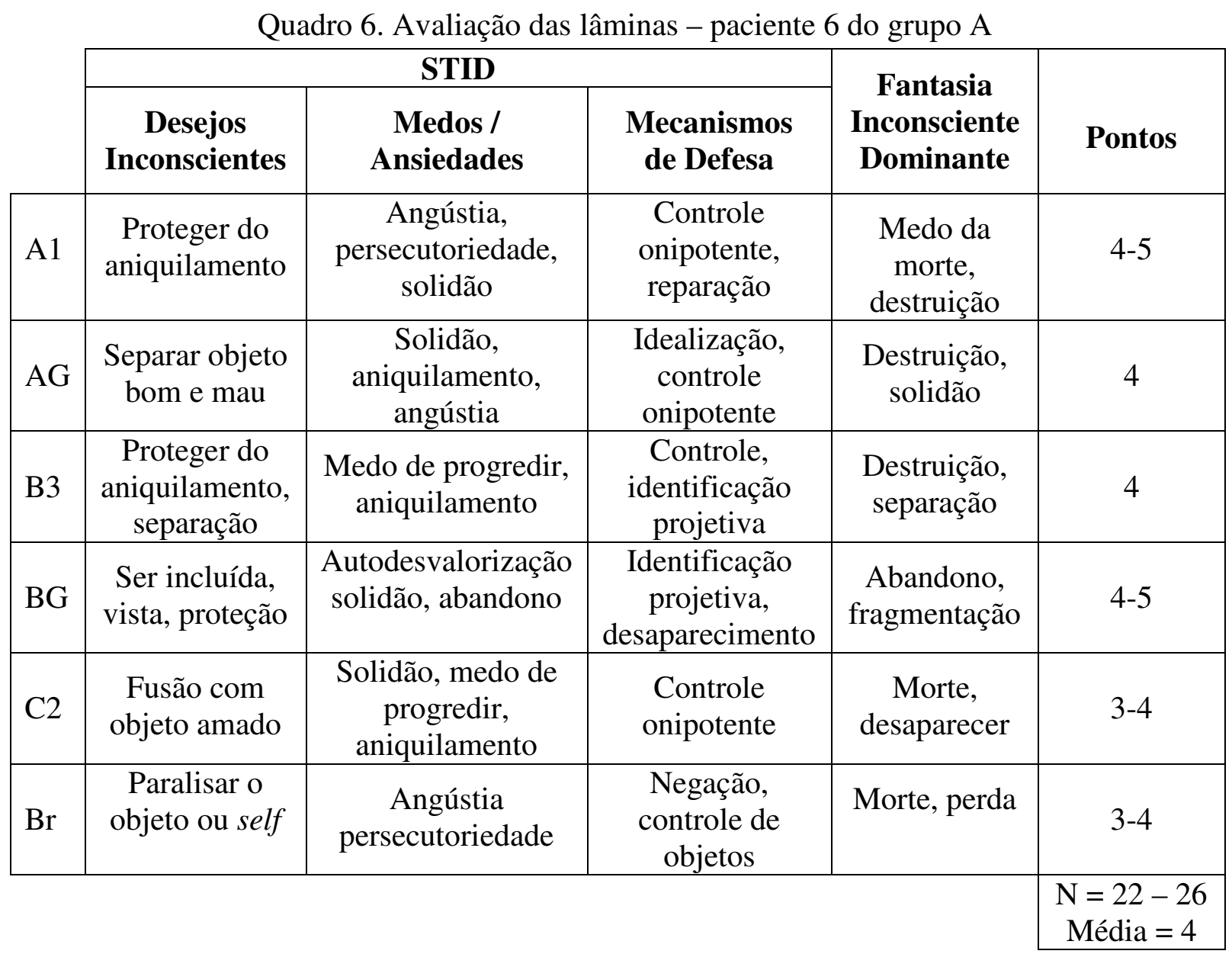

Aspectos manifestos: homem, personagem de filme, rua deserta, filme de terror (A1); mulher, personagem de filme, monges, Indonésia, templo (AG); menino, menor, dois adolescentes, casa, madrugada (B3); pessoa sozinha, crianças, lugar histórico (BG); menina, cama, quarto (C2); jardim com chafariz e flores (Branca).

Análise: distancia-se emocionalmente em A1 citando personagem de filme, porém, mostra angústia (medo do aniquilamento) e capacidade de preservação do self , quando narra 
que deverá “chegar em casa para se proteger” . Faz alusão à situação triangular, espia, sentese entre o pai e a mãe, olha com reprovação e com possibilidade de destruir, requer cuidados de bebê (B3). No entanto, tolera estar de fora desta relação, mantém posição de observadora, o que é positivo em termos prognósticos.

Onipotentemente, controla situações em que sentimentos de angústia (persecutoriedade e aniquilamento) são gerados, distanciando-se da situação apresentada com narrativas de cenas de filmes e lembranças de personagens da literatura (A1, AG e C2), protegendo-se da fantasia inconsciente de morte e destruição.

Presença de sentimentos de solidão e abandono que corroboram com os dados coletados em entrevista, referentes a como se percebe diante do grupo (BG): o self desaparece e é gerado um sentimento de "ser invisível" para os outros, além de intensa inveja.

Medo da morte a paralisa diante da lâmina Branca, distancia-se do conteúdo mobilizado narrando cena com objetos inanimados. Posteriormente, repara e se aproxima, afirmando que narrou o que gostaria de ter em sua casa, o que a deixaria "tranquila".

Tendência a relações de objeto totais. Mantém equilíbrio com possibilidade de relações positivas. Medo intenso de destruição / aniquilamento a fazem lançar mão de defesas arcaicas como paralisação, negação e distanciamento, que a protegem da morte. Ansiedade e culpa persecutória.

\section{- AVALIAÇÃO MULTIAXIAL - EIXO V - DSM-IV}

Escala de Avaliação Global do Funcionamento (AGF) - Pontuação: 65

Sintomas leves, sentimentos de solidão e abandono intensificam ansiedade persecutória e mecanismos de defesa que dificultam contato real com o outro (gerando sensação de “não estar inteira” nas relações). 


\section{PACIENTE 7}

Idade: 60 anos sexo: masculino

HD: TEPT - T. Pânico

- ANÁLISE E INTERPRETAÇÃO DO TRO:

Quadro 7. Avaliação das lâminas - paciente 7 do grupo A

\begin{tabular}{|c|c|c|c|c|c|}
\hline & \multicolumn{3}{|c|}{ STID } & \multirow{2}{*}{$\begin{array}{c}\text { Fantasia } \\
\text { Inconsciente } \\
\text { Dominante }\end{array}$} & \multirow[b]{2}{*}{ Pontos } \\
\hline & $\begin{array}{c}\text { Desejos } \\
\text { Inconscientes }\end{array}$ & $\begin{array}{c}\text { Medos / } \\
\text { Ansiedades }\end{array}$ & $\begin{array}{l}\text { Mecanismos } \\
\text { de Defesa }\end{array}$ & & \\
\hline A1 & $\begin{array}{c}\text { Separar objeto } \\
\text { bom e mau }\end{array}$ & Aniquilamento & $\begin{array}{l}\text { Introjeção do } \\
\text { bom objeto }\end{array}$ & $\begin{array}{c}\text { Perda e } \\
\text { elaboração do } \\
\text { luto }\end{array}$ & $5-6$ \\
\hline $\mathrm{AG}$ & $\begin{array}{l}\text { Proteger do } \\
\text { aniquilamento }\end{array}$ & $\begin{array}{l}\text { Aniquilamento, } \\
\text { angústia, } \\
\text { persecutoriedade }\end{array}$ & $\begin{array}{l}\text { Controle } \\
\text { onipotente }\end{array}$ & $\begin{array}{c}\text { Morte, } \\
\text { desaparecimento }\end{array}$ & 3 \\
\hline B3 & $\begin{array}{l}\text { Separar objeto } \\
\text { bom e mau }\end{array}$ & $\begin{array}{c}\text { Angústia } \\
\text { depressiva, medo } \\
\text { da morte }\end{array}$ & $\begin{array}{l}\text { Reparação } \\
\text { maníaca }\end{array}$ & $\begin{array}{l}\text { Separação, } \\
\text { elaboração do } \\
\text { luto }\end{array}$ & 5 \\
\hline $\mathrm{BG}$ & $\begin{array}{c}\text { Ser visto, } \\
\text { proteger } \\
\text { aniquilamento }\end{array}$ & $\begin{array}{l}\text { Angústia, solidão, } \\
\text { isolamento }\end{array}$ & $\begin{array}{c}\text { Negação } \\
\text { escotomização, } \\
\text { idealização }\end{array}$ & $\begin{array}{c}\text { Solidão, } \\
\text { desaparecimento }\end{array}$ & $3-4$ \\
\hline $\mathrm{C} 2$ & $\begin{array}{c}\text { Separar objeto } \\
\text { bom e mau }\end{array}$ & $\begin{array}{l}\text { Angústia, } \\
\text { persecutoriedade }\end{array}$ & $\begin{array}{c}\text { Negação, } \\
\text { controle } \\
\text { onipotente }\end{array}$ & Morte, perda & 3 \\
\hline $\mathrm{Br}$ & $\begin{array}{c}\text { Paralisar } \\
\text { objeto ou self }\end{array}$ & $\begin{array}{c}\text { Angústia, medo } \\
\text { aniquilamento }\end{array}$ & $\begin{array}{c}\text { Negação, } \\
\text { controle } \\
\text { onipotente }\end{array}$ & $\begin{array}{c}\text { Morte, perda, } \\
\text { destruição }\end{array}$ & 3 \\
\hline & & & & & $\begin{array}{c}\mathrm{N}=22-24 \\
\text { Média }=3,5-4\end{array}$ \\
\hline
\end{tabular}

Aspectos manifestos: homem, água (A1); homem, personagem de filme, conteúdo de realidade negado (AG); casal jovem, casal idoso, futuro (B3); grupo de amigos, pessoa, pessoa sob luz, nega conteúdo de realidade (BG); mulher, homem, casa, quartos espartanos, cama (C2); cartolina, nuvens, céu (Branca).

Análise: situação regressiva em A1 o coloca em posição de reflexão, enfrentamento da solidão, demonstra como reage diante do perigo. Projeta sombra como separação de objetos 
bons e maus, "é a própria sombra, refletida”. Inicialmente, nega situação triangular em B3 porém, repara ao final incluindo criança na relação.

Intensa ansiedade persecutória o leva a necessidade de controle devido angústia de morte ao "caminhar para algo escuro, desconhecido". Impossibilidade de elaborar situação de perda (AG) com defesas maníacas e controle onipotente do conteúdo mobilizado: congela afetos ao se distanciar e narrar cena de filme. Apresenta recursos internos diante do sentimento de isolamento / abandono com capacidade para tolerar o percurso entre estar só e se aproximar do grupo (BG), no entanto, com certa idealização / onipotência presentes na narrativa.

Dificuldade em relação à separação / perda / doença identificada no distanciamento afetivo diante do conteúdo mobilizado em C2, valendo-se de controle onipotente: limita-se à pura descrição da cena com personagens desvitalizados, paralisados, negando morte e utilizando defesas arcaicas. Nega aspectos que seriam projetados na lâmina Branca, demonstrando intensa persecutoriedade na descrição de objetos inanimados representando, novamente, a tentativa de controle onipotente e distanciamento afetivo.

Apresenta tendência adaptativa, oscilando entre resultantes negativas e relações positivas com possibilidade de equilíbrio. Negação e racionalização como defesas fortemente empregadas às situações de desconforto (sofrimento). Temor diante da perda, persecutoriedade e controle onipotente.

\section{- AVALIAÇÃO MULTIAXIAL - EIXO V - DSM-IV}

Escala de Avaliação Global do Funcionamento (AGF) - Pontuação: 53

Sintomas moderados com ataques de pânico ocasionais, controle onipotente e embotamento / distanciamento afetivo mantidos. Presença de organização patológica. 


\section{PACIENTE 8}

Idade: 38 anos sexo: masculino

HD: T. Misto ansioso e depressivo

- ANÁLISE E INTERPRETAÇÃO DO TRO:

Quadro 8. Avaliação das lâminas - paciente 8 do grupo A

\begin{tabular}{|c|c|c|c|c|c|}
\hline & \multicolumn{3}{|c|}{ STID } & \multirow{2}{*}{$\begin{array}{c}\text { Fantasia } \\
\text { Inconsciente } \\
\text { Dominante }\end{array}$} & \multirow[b]{2}{*}{ Pontos } \\
\hline & $\begin{array}{c}\text { Desejos } \\
\text { Inconscientes }\end{array}$ & $\begin{array}{c}\text { Medos / } \\
\text { Ansiedades }\end{array}$ & $\begin{array}{c}\text { Mecanismos } \\
\text { de Defesa }\end{array}$ & & \\
\hline A1 & $\begin{array}{c}\text { Proteger do } \\
\text { aniquilamento }\end{array}$ & $\begin{array}{l}\text { Angústia } \\
\text { persecutória, } \\
\text { ambivalência }\end{array}$ & $\begin{array}{l}\text { Negação, } \\
\text { idealização }\end{array}$ & $\begin{array}{c}\text { Morte, } \\
\text { aniquilamento }\end{array}$ & $3-4$ \\
\hline $\mathrm{AG}$ & $\begin{array}{c}\text { Proteger do } \\
\text { aniquilamento }\end{array}$ & $\begin{array}{c}\text { Morte, } \\
\text { aniquilamento }\end{array}$ & $\begin{array}{c}\text { Negação, } \\
\text { controle } \\
\text { onipotente }\end{array}$ & Morte & $3-2$ \\
\hline B3 & $\begin{array}{c}\text { Fusão com } \\
\text { objeto amado, } \\
\text { simbiose }\end{array}$ & $\begin{array}{c}\text { Solidão, medo de } \\
\text { progredir, } \\
\text { aniquilamento }\end{array}$ & $\begin{array}{c}\text { Paralisação, } \\
\text { identificação } \\
\text { projetiva }\end{array}$ & Morte, solidão & $3-4$ \\
\hline BG & $\begin{array}{l}\text { Ser visto / } \\
\text { reconhecido, } \\
\text { incluído }\end{array}$ & $\begin{array}{l}\text { Autodesvalorização } \\
\text { medo de progredir }\end{array}$ & $\begin{array}{c}\text { Identificação } \\
\text { projetiva }\end{array}$ & $\begin{array}{l}\text { Aniquilamento } \\
\text { solidão }\end{array}$ & 3 \\
\hline $\mathrm{C} 2$ & $\begin{array}{l}\text { Fusão com o } \\
\text { objeto amado }\end{array}$ & $\begin{array}{l}\text { Aniquilamento e } \\
\text { angústia }\end{array}$ & $\begin{array}{c}\text { Cisão - } \\
\text { clivagem, } \\
\text { negação }\end{array}$ & Morte, solidão & $2-3$ \\
\hline $\mathrm{Br}$ & $\begin{array}{l}\text { Separar objeto } \\
\text { bom e mau }\end{array}$ & $\begin{array}{c}\text { Angústia } \\
\text { depressiva, luto } \\
\text { pela destruição }\end{array}$ & $\begin{array}{l}\text { Reparação } \\
\text { maníaca } \\
\text { (culpa) }\end{array}$ & $\begin{array}{c}\text { Perda e } \\
\text { elaboração do } \\
\text { luto } \\
\end{array}$ & $5-6$ \\
\hline & & & & & $\begin{array}{c}\mathrm{N}=19-24 \\
\text { Média }=3-4\end{array}$ \\
\hline
\end{tabular}

Aspectos manifestos: homem, mancha (A1); pessoas, morto, árvore (AG); casal, criança, filho, pai, conteúdo de realidade negado (B3); grupo de amigos, homem sozinho, bar, igreja (BG); mulher, criança (rosto), cama, casa (C2); nenhum aspecto manifesto (Branca).

Análise: angústia mobilizada em A1 presente na narrativa de solidão somada a sofrimento agudo. Mostra caminho para solucionar conflito, porém não soluciona (ambivalência). 
Visualiza, inicialmente, situação triangular (B3) com foco na relação do pai que abandona filho. Apesar do sentimento de abandono, apresenta capacidade para tolerar a frustração: “quando o pai vai embora, o filho fica sem ação, parado e chateado".

Onipotentemente controla angústia mobilizada na $\mathrm{AG}$, cenário de morte e pessoas rezando, distanciando-se da angústia ao vislumbrar uma árvore na cena e encerrando narrativa (elaboração maníaca - defesa maníaca de estrutura esquizóide).

Sentimento de exclusão diante do grupo (BG) com capacidade egóica para enfrentamento: permanece no ambiente ameaçador. Intensa solidão e insegurança.

Personagem que se aproxima em C2 parece portador de conteúdos destrutivos / ameaçadores e a relação fica cindida com o aparecimento de novas elaborações maníacas para a situação.

Demonstra alguma condição para reparar na lâmina Branca, com culpa (pela destruição), admitindo sentimento desagradável durante o exame e afirmando que, neste momento, gostaria de solucionar problemas e reescrever situações com um novo final, sinal característico da posição depressiva. Tendência adaptativa com algumas resultantes negativas. Temor diante do sentimento de solidão e angústia frente à morte. Persecutoriedade.

\section{- AVALIAÇÃO MULTIAXIAL - EIXO V - DSM-IV}

Escala de Avaliação Global do Funcionamento (AGF) - Pontuação: 52

Sintomas moderados (predominantemente fóbicos), embotamento afetivo, alguns traços caracterológicos com restrições (contato social / ocupacional). Humor lábil gera oscilações quanto à manutenção de escolhas. 


\section{PACIENTE 9}

Idade: 23 sexo: feminino

HD: T. Misto ansioso e depressivo.

\section{- ANÁLISE E INTERPRETAÇÃO DO TRO:}

Quadro 9. Avaliação das lâminas - paciente 9 do grupo A

\begin{tabular}{|c|c|c|c|c|c|}
\hline & \multicolumn{3}{|c|}{ STID } & \multirow{2}{*}{$\begin{array}{c}\text { Fantasia } \\
\text { Inconsciente } \\
\text { Dominante }\end{array}$} & \multirow[b]{2}{*}{ Pontos } \\
\hline & $\begin{array}{c}\text { Desejos } \\
\text { Inconscientes }\end{array}$ & $\begin{array}{c}\text { Medos / } \\
\text { Ansiedades }\end{array}$ & $\begin{array}{l}\text { Mecanismos } \\
\text { De Defesa }\end{array}$ & & \\
\hline A1 & $\begin{array}{l}\text { Ser visto, } \\
\text { notado }\end{array}$ & $\begin{array}{l}\text { Aniquilamento, } \\
\text { solidão }\end{array}$ & Escotomização & Morte, solidão & $3-4$ \\
\hline AG & $\begin{array}{l}\text { Proteger do } \\
\text { aniquilamento }\end{array}$ & $\begin{array}{l}\text { Morte, angústia } \\
\text { persecutória }\end{array}$ & $\begin{array}{c}\text { Identificação } \\
\text { projetiva }\end{array}$ & $\begin{array}{c}\text { Morte, } \\
\text { desaparecimen } \\
\text { to }\end{array}$ & 4 \\
\hline B3 & $\begin{array}{c}\text { Ser notado, } \\
\text { proteger do } \\
\text { aniquilamento }\end{array}$ & $\begin{array}{l}\text { Aniquilamento, } \\
\text { progredir }\end{array}$ & $\begin{array}{l}\text { Negação, controle } \\
\text { onipotente }\end{array}$ & $\begin{array}{c}\text { Separação, } \\
\text { elaboração do } \\
\text { luto }\end{array}$ & 4 \\
\hline BG & $\begin{array}{l}\text { Proteger do } \\
\text { aniquilamento }\end{array}$ & Solidão, morte & $\begin{array}{c}\text { Identificação } \\
\text { projetiva }\end{array}$ & Perda, morte & $2-3$ \\
\hline $\mathrm{C} 2$ & $\begin{array}{l}\text { Fusão com o } \\
\text { objeto amado }\end{array}$ & $\begin{array}{l}\text { Aniquilamento, } \\
\text { progredir }\end{array}$ & $\begin{array}{c}\text { Desaparecimento, } \\
\text { negação }\end{array}$ & Morte, solidão & $3-4$ \\
\hline $\mathrm{Br}$ & $\begin{array}{l}\text { Separar objeto } \\
\text { bom e mau }\end{array}$ & $\begin{array}{c}\text { Angústia } \\
\text { depressiva, luto }\end{array}$ & $\begin{array}{l}\text { Reparação } \\
\text { maníaca }\end{array}$ & $\begin{array}{c}\text { Perda, } \\
\text { elaboração do } \\
\text { luto }\end{array}$ & 5 \\
\hline & & & & & $\begin{array}{l}\mathrm{N}=21-24 \\
\text { Média }=3,5-4\end{array}$ \\
\hline
\end{tabular}

Aspectos manifestos: homem, pessoa agachada, lugar ermo, escuro (A1); três homens ajoelhados, soldados, mortos, sepultura, cemitério (AG); casal apaixonado, mãe espiã, casa, quarto (B3); menino, amigos, janela, porta (BG); menina triste, quarto, inverno (C2); paciente, folha em branco (Branca). 
Análise: situação nova é geradora de angústia e sentimento de solidão em A1. Quer ser notada (não foi notada pela mãe, quer ser notada em análise - relação transferencial).

Faz referência à relação triangular em B3, insere mãe como espiã de um casal proibido (situação edípica - interdição). Intenso sentimento de tristeza diante da perda leva ao congelamento dos afetos e mobiliza defesas maníacas.

Há elaboração parcial com parte do ego comprometida com a perda, identificada na criação de um personagem "mais ocupado com as mortes que os demais".

Vislumbra o futuro em C2 como um lugar que não quer ir e segue com tristeza.

Nega morte (não cita personagem na cama) e desloca para sentimento de tristeza da menina, com identificação projetiva. Defende-se com fala de que "é inverno, e no inverno as pessoas são tristes mesmo”.

Capacidade de reparação devido angústia e culpa, identificadas na lâmina Branca, colocando-se como personagem portadora de angústia depressiva, em luto pela destruição do objeto e com rebaixamento de defesas.

Possibilidade de manter equilíbrio, com tendência adaptativa. Algumas resultantes negativas.

\section{- AVALIAÇÃO MULTIAXIAL - EIXO V - DSM-IV}

Escala de Avaliação Global do Funcionamento (AGF) - Pontuação: 60

Sintomas moderados (embotamento afetivo), com capacidade para tolerar frustrações apesar de intensos mecanismos de negação e identificação projetiva.

Sentimento de solidão e abandono foram frequentes. 


\section{PACIENTE 10}

Idade: 28 anos sexo: feminino

HD: Transtorno Afetivo Bipolar / Transtorno de Pânico

- ANÁLISE E INTERPRETAÇÃO DO TRO:

Quadro 10. Avaliação das lâminas - paciente 10 do grupo A

\begin{tabular}{|c|c|c|c|c|c|}
\hline & \multicolumn{3}{|c|}{ STID } & \multirow{2}{*}{$\begin{array}{c}\text { Fantasia } \\
\text { Inconsciente } \\
\text { Dominante }\end{array}$} & \multirow[b]{2}{*}{ Pontos } \\
\hline & $\begin{array}{c}\text { Desejos } \\
\text { Inconscientes }\end{array}$ & $\begin{array}{c}\text { Medos / } \\
\text { Ansiedades }\end{array}$ & $\begin{array}{l}\text { Mecanismos } \\
\text { De Defesa }\end{array}$ & & \\
\hline A1 & $\begin{array}{c}\text { Paralisar o } \\
\text { objeto ou self }\end{array}$ & Solidão & $\begin{array}{l}\text { Controle } \\
\text { onipotente }\end{array}$ & $\begin{array}{c}\text { Morte / } \\
\text { desaparecimento }\end{array}$ & 3 \\
\hline AG & $\begin{array}{l}\text { Proteger do } \\
\text { aniquilamento }\end{array}$ & $\begin{array}{l}\text { Angústia } \\
\text { depressiva }\end{array}$ & $\begin{array}{l}\text { Identificação } \\
\text { projetiva }\end{array}$ & $\begin{array}{c}\text { Morrer / } \\
\text { desaparecer }\end{array}$ & 4 \\
\hline B3 & $\begin{array}{l}\text { Separar objeto } \\
\text { bom e mau }\end{array}$ & $\begin{array}{l}\text { Angústia } \\
\text { depressiva }\end{array}$ & $\begin{array}{l}\text { Introjeção do bom } \\
\text { objeto }\end{array}$ & Separação & $5-6$ \\
\hline BG & $\begin{array}{l}\text { Separar } \\
\text { objetos }\end{array}$ & Aniquilamento & $\begin{array}{l}\text { Introjeção do bom } \\
\text { objeto }\end{array}$ & $\begin{array}{c}\text { Perda e } \\
\text { elaboração / } \\
\text { separação }\end{array}$ & $5-6$ \\
\hline $\mathrm{C} 2$ & $\begin{array}{l}\text { Proteger do } \\
\text { aniquilamento }\end{array}$ & $\begin{array}{l}\text { Medo de } \\
\text { progredir }\end{array}$ & $\begin{array}{c}\text { Controle } \\
\text { onipotente, } \\
\text { negação }\end{array}$ & $\begin{array}{l}\text { Destruição do } \\
\text { objeto }\end{array}$ & 3 \\
\hline $\mathrm{Br}$ & $\begin{array}{l}\text { Proteger do } \\
\text { aniquilamento }\end{array}$ & Solidão & $\begin{array}{l}\text { Reparação } \\
\text { maníaca }\end{array}$ & $\begin{array}{c}\text { Perda e } \\
\text { elaboração do } \\
\text { luto }\end{array}$ & $4-5$ \\
\hline & & & & & $\begin{array}{c}\mathrm{N}=24-26 \\
\text { Média }=4,5\end{array}$ \\
\hline
\end{tabular}

Aspectos manifestos: homem, cachoeira, pedras (A1); almas, pessoas, mortos, árvores, campo verde (AG); casal, pessoas, luz, quarto (B3); rapaz, amigos, trem, trilhos, portais (BG); viajante, quarto de pensão antigo (C2); pássaro, nuvens (Branca).

Análise: Inicia sua narrativa (A1) citando homem sozinho, que está parado, apenas "olhando e refletindo", ao lado de pedras, parece petrificado também, sem ação, tornou-se objeto inanimado. Demonstra desejo de paralisar o objeto e apresenta fantasia inconsciente 
dominante de morte e desaparecimento do self. Repara ao final relatando que este homem "pensa na vida", busca intensidade / expansão no personagem que inicialmente estava, apenas, "pensando no dia”.

A situação triangular é respeitada (B3), apresenta ansiedade controlada e capacidade para tolerar situação de terceiro excluído que expia casal em sua intimidade (apenas observa, com olhar despretensioso). Sente depressivamente a situação colocada em AG, porém com certa resistência em lidar com suas perdas (luto) já que "alguns conseguem seguir o caminho, outros continuam presos”, referindo-se às almas identificadas na lâmina.

Diferencia claramente um dos indivíduos do grupo (BG) e não lhe confere autoridade, "ele apenas segue um caminho diferente". Importante sentimento de rejeição, de não pertencer ao grupo, porém narra isolamento por desejo próprio.

Luto pelas situações presentes e futuras (C2), abdica de desejos e se defende através de mecanismo de controle onipotente afirmando que "não liga, é assim mesmo" e negando condição de perda. Ignora personagem na cama. Apresenta capacidade para reparar danos causados ao objeto (Branca), apesar de intensas oscilações e sentimentos ambivalentes presentes durante todo o exame, que corroboram com a hipótese diagnóstica da paciente. Importante sentimento de solidão para o enfrentamento de seus problemas / doença. Defesas das posições esquizoparanóide e depressiva (oscilam).

\section{- AVALIAÇÃO MULTIAXIAL - EIXO V - DSM-IV}

Escala de Avaliação Global do Funcionamento (AGF) - Pontuação: 60

Crises de pânico e oscilações de humor, histórico de perdas significativas (lutos), com capacidade para enfrentamento (recursos internos identificados) e disponibilidade para análise pessoal / comprometimento. 


\section{GRUPO B}

\section{PACIENTE 1}

Idade: 63 anos sexo: masculino

HD: ICO (Insuficiência Coronariana)

Classe Funcional NYHA: CF I

- ANÁLISE E INTERPRETAÇÃO DO TRO:

Quadro 11. Avaliação das lâminas - paciente 1 do grupo B:

\begin{tabular}{|c|c|c|c|c|c|}
\hline & \multicolumn{3}{|c|}{ STID } & \multirow{2}{*}{$\begin{array}{c}\text { Fantasia } \\
\text { Inconsciente } \\
\text { Dominante }\end{array}$} & \multirow[b]{2}{*}{ Pontos } \\
\hline & $\begin{array}{c}\text { Desejos } \\
\text { Inconscientes }\end{array}$ & $\begin{array}{c}\text { Medos / } \\
\text { Ansiedades }\end{array}$ & $\begin{array}{c}\text { Mecanismos } \\
\text { de Defesa }\end{array}$ & & \\
\hline A1 & $\begin{array}{c}\text { Paralisar o } \\
\text { objeto ou self }\end{array}$ & Aniquilamento & $\begin{array}{c}\text { Identificação } \\
\text { projetiva }\end{array}$ & Paralisação & 3 \\
\hline $\mathrm{AG}$ & $\begin{array}{c}\text { Paralisar o } \\
\text { objeto ou self }\end{array}$ & Aniquilamento & Negação & Desaparecimento & $2-3$ \\
\hline B3 & $\begin{array}{c}\text { Proteger do } \\
\text { aniquilamento }\end{array}$ & $\begin{array}{c}\text { Angústia / } \\
\text { persecutoriedade }\end{array}$ & $\begin{array}{c}\text { Identificação } \\
\text { projetiva }\end{array}$ & $\begin{array}{c}\text { Morte / } \\
\text { destruição }\end{array}$ & 3 \\
\hline BG & $\begin{array}{c}\text { Paralisar o } \\
\text { objeto ou self }\end{array}$ & Aniquilamento & $\begin{array}{c}\text { Identificação } \\
\text { projetiva / } \\
\text { reparação }\end{array}$ & $\begin{array}{c}\text { Morte / } \\
\text { desaparecimento }\end{array}$ & 3 \\
\hline $\mathrm{C} 2$ & $\begin{array}{c}\text { Paralisar o } \\
\text { objeto ou self }\end{array}$ & $\begin{array}{l}\text { Medo de } \\
\text { progredir }\end{array}$ & $\begin{array}{c}\text { Negação / } \\
\text { escotomização }\end{array}$ & Fragmentação & 3 \\
\hline $\mathrm{Br}$ & $\begin{array}{l}\text { Proteger do } \\
\text { aniquilamento }\end{array}$ & $\begin{array}{l}\text { Angústia } \\
\text { depressiva }\end{array}$ & Negação & $\begin{array}{c}\text { Elaboração do } \\
\text { luto }\end{array}$ & 3 \\
\hline & & & & & $\begin{array}{c}\mathrm{N}=17-18 \\
\text { Média }=3\end{array}$ \\
\hline
\end{tabular}

Aspectos manifestos: paciente, cor escura (A1); pessoas, foto (AG); paciente e esposa, espião, armário de hospital (B3); pacientes, sala de cirurgia (BG); pessoa, jardim (C2); paciente (Branca). 
Análise: identifica-se com personagem paralisado em A1, "parado, quieto, com os braços esticados" e nega cenário. A situação de teste apresentada gera paralisação neste primeiro momento.

Considera cena com situação triangular (B3) e o terceiro está excluído, “observando”. Apresenta o desejo de ser olhado / observado.

O mecanismo de identificação projetiva o insere como personagem em BG. Demonstra intensa angústia / persecutoriedade ao se apresentar como paciente em um centro cirúrgico. Ao final, repara destruição dizendo que a cirurgia “correu bem, acabou bem”.

Paralisa personagens em AG devido medo de aniquilamento. Transforma pessoas em uma foto, apresentadas como desvitalizadas e se utilizando do mecanismo de negação diante do conteúdo emergido pela lâmina.

Medo intenso, também identificado em C2, o leva a nova paralisação do objeto, deixando-o "quietinho em um bonito jardim". Identificado distanciamento afetivo e mecanismo de negação.

Nega, novamente, condição atual de saúde (Branca). Porém, valoriza melhora clínica (angústia depressiva). Demonstra ambivalência importante e atribui a conquista de evolução clínica positiva ao poder de Deus, eximindo-se da responsabilidade por sua saúde.

Estabelece relações de objeto parciais e se utiliza predominantemente de defesas arcaicas do desenvolvimento. Tendência adaptativa com resultante positiva.

\section{- AVALIAÇÃO MULTIAXIAL - EIXO V - DSM-IV}

Escala de Avaliação Global do Funcionamento (AGF) - Pontuação: 53

Apresenta sintomas moderados (estado maníaco), distanciamento afetivo e negação da condição clínica. Prejuízos no autocuidado. 


\section{PACIENTE 2}

Idade: 75 anos sexo: feminino

HD: IC (Insuficiência Cardíaca)

Classe Funcional NYHA: CF II

- ANÁLISE E INTERPRETAÇÃO DO TRO:

Quadro 12. Avaliação das lâminas - paciente 2 do grupo B:

\begin{tabular}{|c|c|c|c|c|c|}
\hline & \multicolumn{3}{|c|}{ STID } & \multirow{2}{*}{$\begin{array}{c}\text { Fantasia } \\
\text { Inconsciente } \\
\text { Dominante }\end{array}$} & \multirow[b]{2}{*}{ Pontos } \\
\hline & $\begin{array}{c}\text { Desejos } \\
\text { Inconscientes }\end{array}$ & $\begin{array}{c}\text { Medos / } \\
\text { Ansiedades }\end{array}$ & $\begin{array}{l}\text { Mecanismos } \\
\text { de Defesa }\end{array}$ & & \\
\hline A1 & $\begin{array}{l}\text { Separar } \\
\text { objetos, } \\
\text { paralisar }\end{array}$ & $\begin{array}{l}\text { Angústia - } \\
\text { persecutoriedade }\end{array}$ & $\begin{array}{c}\text { Identificação } \\
\text { projetiva }\end{array}$ & Paralisação & 3 \\
\hline AG & $\begin{array}{c}\text { Paralisar o } \\
\text { objeto ou self }\end{array}$ & $\begin{array}{l}\text { Ansiedade } \\
\text { confusional }\end{array}$ & $\begin{array}{c}\text { Controle } \\
\text { onipotente }\end{array}$ & Paralisação & 3 \\
\hline B3 & $\begin{array}{l}\text { Fusão com o } \\
\text { objeto }\end{array}$ & $\begin{array}{c}\text { Medo do } \\
\text { aniquilamento }\end{array}$ & Negação & Fragmentação & $2-3$ \\
\hline $\mathrm{BG}$ & $\begin{array}{l}\text { Separar } \\
\text { objetos }\end{array}$ & $\begin{array}{l}\text { Não ser vista, } \\
\text { notada }\end{array}$ & Desaparecimento & Aniquilamento & 3 \\
\hline $\mathrm{C} 2$ & $\begin{array}{c}\text { Paralisar o } \\
\text { objeto ou self }\end{array}$ & $\begin{array}{c}\text { Morte, } \\
\text { aniquilamento }\end{array}$ & $\begin{array}{c}\text { Negação, } \\
\text { identificação } \\
\text { projetiva }\end{array}$ & Aniquilamento & 2 \\
\hline $\mathrm{Br}$ & $\begin{array}{c}\text { Paralisar o } \\
\text { objeto ou self }\end{array}$ & Aniquilamento & $\begin{array}{c}\text { Negação / } \\
\text { escotomização }\end{array}$ & Aniquilamento & 2 \\
\hline & & & & & $\begin{array}{c}\mathrm{N}=15-17 \\
\text { Média }=2,5-3\end{array}$ \\
\hline
\end{tabular}

Aspectos manifestos: pessoa, homem, nuvens, lugar escuro e ruim (A1); pessoas, mar, peixes, baleias, árvore (AG); pessoas, casal, conteúdo de realidade negado (B3); homem, pessoas, muralha de tempos antigos, porta, janela (BG); pessoa, homem, lugar triste (C2); futuro (Branca). 
Análise: diante da primeira lâmina (A1), foram mobilizados conteúdos angustiantes que a levaram a paralisar o personagem narrado e o manter em um "lugar escuro e ruim", sentindo-se sozinho e sem recursos para sair deste ambiente.

Nega situação triangular (B3), apresenta alternativa menos adaptativa, como necessidade de controle da ansiedade persecutória.

Não sente depressivamente a situação colocada em AG, a angústia depressiva foi substituída pela ansiedade confusional e, novamente, paralisação dos objetos.

Narra história de exclusão e solidão diante do outro (BG), com importante sentimento de rejeição projetado no grupo e indiferença frente a seus pares.

O personagem acamado é negado em C2 demonstrando a relação estabelecida entre a paciente e sua doença (negação). Apresenta sentimento de desesperança e solidão. A morte é negada e deslocada para o conteúdo de realidade: "lugar triste".

Reage defensivamente à lâmina Branca com intensa persecutoriedade, afastando-se afetivamente do conteúdo mobilizado e negando aspectos do mundo interno. Controla onipotentemente atribuindo título "positivo" à narrativa.

Tendência adaptativa. No entanto, não mantém equilíbrio e há predomínio de ansiedade e relações negativas.

\section{- AVALIAÇÃO MULTIAXIAL - EIXO V - DSM-IV}

Escala de Avaliação Global do Funcionamento (AGF) - Pontuação: 55

Embotamento afetivo e fala circunstancial. Distanciamento do conteúdo interno nas relações, ansiedade persecutória. 


\section{PACIENTE 3}

Idade: 46 anos sexo: masculino

HD: IC (Insuficiência Cardíaca)

Classe Funcional NYHA: CF II (atualmente II - III)

\section{- ANÁLISE E INTERPRETAÇÃO DO TRO:}

Quadro 13. Avaliação das lâminas - paciente 3 do grupo B:

\begin{tabular}{|c|c|c|c|c|c|}
\hline & \multicolumn{3}{|c|}{ STID } & \multirow{2}{*}{$\begin{array}{c}\text { Fantasia } \\
\text { Inconsciente } \\
\text { Dominante }\end{array}$} & \multirow[b]{2}{*}{ Pontos } \\
\hline & $\begin{array}{c}\text { Desejos } \\
\text { Inconscientes }\end{array}$ & $\begin{array}{c}\text { Medos / } \\
\text { Ansiedades }\end{array}$ & $\begin{array}{l}\text { Mecanismos } \\
\text { de Defesa }\end{array}$ & & \\
\hline A1 & $\begin{array}{l}\text { Proteger do } \\
\text { aniquilamento }\end{array}$ & Morte, solidão & $\begin{array}{l}\text { Identificação } \\
\text { projetiva }\end{array}$ & $\begin{array}{c}\text { Morte, } \\
\text { desaparecimento }\end{array}$ & 3 \\
\hline $\mathrm{AG}$ & $\begin{array}{c}\text { Paralisar o } \\
\text { objeto ou self }\end{array}$ & $\begin{array}{l}\text { Ansiedade } \\
\text { confusional }\end{array}$ & Negação & Paralisação & $2-3$ \\
\hline B3 & $\begin{array}{c}\text { Separar } \\
\text { objeto bom e } \\
\text { mau }\end{array}$ & $\begin{array}{l}\text { Angústia } \\
\text { depressiva }\end{array}$ & $\begin{array}{l}\text { Introjeção do } \\
\text { bom objeto }\end{array}$ & Separação & $4-5$ \\
\hline BG & $\begin{array}{c}\text { Separar } \\
\text { objeto bom e } \\
\text { mau }\end{array}$ & Solidão & $\begin{array}{l}\text { Introjeção do } \\
\text { bom objeto }\end{array}$ & $\begin{array}{l}\text { Elaboração do } \\
\text { luto }\end{array}$ & $4-5$ \\
\hline $\mathrm{C} 2$ & $\begin{array}{l}\text { Fusão com } \\
\text { objeto }\end{array}$ & $\begin{array}{c}\text { Angústia / } \\
\text { persecutoriedade, } \\
\text { desesperança }\end{array}$ & $\begin{array}{c}\text { Cisão/clivagem } \\
\text { controle } \\
\text { onipotente }\end{array}$ & Fragmentação & $2-3$ \\
\hline $\mathrm{Br}$ & $\begin{array}{l}\text { Proteger do } \\
\text { aniquilamento }\end{array}$ & $\begin{array}{c}\text { Ambivalência, } \\
\text { medo de } \\
\text { progredir }\end{array}$ & $\begin{array}{l}\text { Controle } \\
\text { onipotente }\end{array}$ & $\begin{array}{c}\text { Destruição do } \\
\text { objeto }\end{array}$ & 3 \\
\hline & & & & & $\begin{array}{c}\mathrm{N}=18-22 \\
\text { Média }=3,5\end{array}$ \\
\hline
\end{tabular}

Aspectos manifestos: pessoa, homem, sombra, nevoeiro, bairro tradicional (A1); pessoa, nevoeiro, borrão, neblina (AG); homem, mulher, casal de namorados, pessoa, mãe, filha, porta, casa (B3); italianos, japoneses, pessoas, estação de trem, arcos (BG); homem, cabeça, casa, quarto, pintura, prisão (C2); ponto, chapéu mexicano, branco (Branca). 
Análise: a situação nova de teste gera angústia (A1). É colocado diante de sua solidão e vislumbra a possibilidade de seguir adiante, caminhando no nevoeiro.

Admite a configuração triangular em B3, o terceiro espia e está excluído da relação do casal, mostra-se presente diante de um par unido mas não interfere na dupla.

Parte do ego sofre pelo objeto perdido e observa o nevoeiro (AG), gerando ansiedade confusional e controle onipotente com distanciamento afetivo em relação ao conteúdo que foi mobilizado.

Coloca-se em situação equivalente referente aos seus pares (BG). Aparecem fantasias de continente transitório com capacidade para tolerar o percurso (doença - saúde).

Narra personagem portador de fantasias de desesperança $(\mathrm{C} 2)$ que percebe seu mundo interno como "prisão". Esta é a relação que estabelece com seu diagnóstico / doença. Onipotentemente, controla cena se recordando de um quadro que projeta suas partes fragmentadas, com a “cabeça fora do corpo”.

Apresenta possibilidade de preparo para reparação e recomeço, porém controla onipotentemente a situação apresentada (Branca) demonstrando ambivalência referente ao que projeta como seu futuro e quanto aos recursos disponíveis para enfrentamento.

Equilíbrio pode ser mantido com tendência adaptativa, gerando possíveis relações positivas. Relações objetais de fases esquizoparanóide e depressiva.

\section{- AVALIAÇÃO MULTIAXIAL - EIXO V - DSM-IV}

Escala de Avaliação Global do Funcionamento (AGF) - Pontuação: 59

Fala racionalizada com sintomas moderados de ansiedade, alguns ataques de pânico ocasionais. Conflitos no trabalho com poucos recursos para enfrentamento. 


\section{PACIENTE 4}

Idade: 60 anos sexo: masculino

HD: IC (Insuficiência Cardíaca)

Classe Funcional NYHA: CF II - I (atualmente I)

\section{- ANÁLISE E INTERPRETAÇÃO DO TRO:}

Quadro 14. Avaliação das lâminas - paciente 4 do grupo B:

\begin{tabular}{|c|c|c|c|c|c|}
\hline & \multicolumn{3}{|c|}{ STID } & \multirow{2}{*}{$\begin{array}{c}\text { Fantasia } \\
\text { Inconsciente } \\
\text { Dominante }\end{array}$} & \multirow[b]{2}{*}{ Pontos } \\
\hline & $\begin{array}{c}\text { Desejos } \\
\text { Inconscientes }\end{array}$ & $\begin{array}{c}\text { Medos / } \\
\text { Ansiedades }\end{array}$ & $\begin{array}{c}\text { Mecanismos } \\
\text { de Defesa }\end{array}$ & & \\
\hline A1 & $\begin{array}{l}\text { Ser cuidado, } \\
\text { ser visto }\end{array}$ & $\begin{array}{c}\text { Medo do } \\
\text { aniquilamento }\end{array}$ & $\begin{array}{c}\text { Identificação } \\
\text { projetiva }\end{array}$ & Dependência & 3 \\
\hline AG & $\begin{array}{c}\text { Separar } \\
\text { objeto bom e } \\
\text { mau } \\
\end{array}$ & $\begin{array}{l}\text { Angústia } \\
\text { depressiva }\end{array}$ & $\begin{array}{l}\text { Introjeção do } \\
\text { bom objeto }\end{array}$ & Separação & $4-5$ \\
\hline B3 & $\begin{array}{c}\text { Olhar e ser } \\
\text { olhado }\end{array}$ & $\begin{array}{c}\text { Solidão, } \\
\text { desaparecimento, } \\
\text { inveja }\end{array}$ & $\begin{array}{c}\text { Identificação } \\
\text { projetiva }\end{array}$ & Separação & $3-4$ \\
\hline $\mathrm{BG}$ & $\begin{array}{c}\text { Paralisar o } \\
\text { objeto ou self }\end{array}$ & Ambivalência & Paralisação & Dependência & 3 \\
\hline $\mathrm{C} 2$ & $\begin{array}{c}\text { Paralisar o } \\
\text { objeto ou self }\end{array}$ & $\begin{array}{c}\text { Morte, } \\
\text { aniquilamento }\end{array}$ & $\begin{array}{c}\text { Identificação } \\
\text { projetiva, } \\
\text { paralisação }\end{array}$ & Fragmentação & 3 \\
\hline $\mathrm{Br}$ & $\begin{array}{l}\text { Proteger do } \\
\text { aniquilamento }\end{array}$ & $\begin{array}{c}\text { Angústia, } \\
\text { aniquilamento, } \\
\text { desaparecimento }\end{array}$ & $\begin{array}{c}\text { Identificação } \\
\text { projetiva, } \\
\text { negação }\end{array}$ & $\begin{array}{l}\text { Elaboração do } \\
\text { luto }\end{array}$ & $3-4$ \\
\hline & & & & & $\begin{array}{c}\mathrm{N}=19-22 \\
\text { Média }=3,5\end{array}$ \\
\hline
\end{tabular}

Aspectos manifestos: ser humano, criança, vulto, sombra, paisagem, fumaça (A1); pessoas, árvore (AG); pessoas, criança, cômoda, porta (B3); crianças, rapaz, janela, porta (BG); pessoa doente, Deus, porta, quarto, cama (C2); branco (Branca). 
Análise: o temor ante o desconhecido o leva a incluir um segundo personagem (criança) que acompanha o homem inquieto (acompanha em silêncio). Estabelece uma relação transferencial de dependência (A1).

Admite a situação triangular (B3) com o terceiro como excluído na relação do homem com uma criança (espia). A inveja aparece como característica naquele que observa a cena (e não participa).

Sente perdas com inquietação e reage observando cena apresentada na lâmina AG com angústia e tristeza pelo objeto perdido. Visualiza aspectos destrutivos e reparadores inserindo um mesmo número de pessoas à direita e à esquerda, incluídas na narrativa como forças opositoras. Coloca-se como excluído diante de seus pares (BG) com fantasias de continente estável (predomínio de paralisação de objeto), com limitada condição / capacidade para tolerar o percurso saúde - doença e enfrentar o futuro, ficando "sem atitude”.

Diante do luto, descarta enfrentamento para elaboração e paralisa (C2), atribui à Deus esta possível conquista e mantém o papel de observador passivo. Demonstra recursos limitados para enfrentamento da situação clínica, nega condição atual (Branca), angustia-se com prescrição médica e necessita de reforçamento referente á importância do autocuidado.

Há possibilidade de manter equilíbrio e relações positivas com tendência adaptativa.

A adaptação pode ser comprometida devido à presença significativa de ambivalência e ao estabelecimento de relações de dependência com o mundo externo.

\section{- AVALIAÇÃO MULTIAXIAL - EIXO V - DSM-IV}

Escala de Avaliação Global do Funcionamento (AGF) - Pontuação: 61

Alguns sintomas leves devido à condição clínica atual, distanciamento afetivo em algumas situações, histórico de autocuidado prejudicado. 


\section{PACIENTE 5}

Idade: 55 anos sexo: masculino

HD: IC (Insuficiência Cardíaca)

Classe Funcional NYHA: CF II - I (atualmente I)

- ANÁLISE E INTERPRETAÇÃO DO TRO:

Quadro 15. Avaliação das lâminas - paciente 5 do grupo B:

\begin{tabular}{|c|c|c|c|c|c|}
\hline & \multicolumn{3}{|c|}{ STID } & \multirow{2}{*}{$\begin{array}{c}\text { Fantasia } \\
\text { Inconsciente } \\
\text { Dominante }\end{array}$} & \multirow[b]{2}{*}{ Pontos } \\
\hline & $\begin{array}{c}\text { Desejos } \\
\text { Inconscientes }\end{array}$ & $\begin{array}{c}\text { Medos / } \\
\text { Ansiedades }\end{array}$ & $\begin{array}{l}\text { Mecanismos } \\
\text { de Defesa }\end{array}$ & & \\
\hline A1 & $\begin{array}{c}\text { Fusão com o } \\
\text { objeto }\end{array}$ & $\begin{array}{c}\text { Medo do } \\
\text { aniquilamento }\end{array}$ & $\begin{array}{l}\text { Identificação } \\
\text { projetiva }\end{array}$ & Fragmentação & 3 \\
\hline $\mathrm{AG}$ & $\begin{array}{c}\text { Paralisar o } \\
\text { objeto ou self }\end{array}$ & $\begin{array}{l}\text { Ansiedade } \\
\text { confusional }\end{array}$ & $\begin{array}{c}\text { Paralisação, } \\
\text { desaparecimento } \\
\text { do self }\end{array}$ & $\begin{array}{c}\text { Desumanização, } \\
\text { paralisação }\end{array}$ & 2 \\
\hline B3 & $\begin{array}{c}\text { Fusão com o } \\
\text { objeto }\end{array}$ & $\begin{array}{l}\text { Inveja, medo de } \\
\text { progredir }\end{array}$ & $\begin{array}{c}\text { Negação / } \\
\text { escotomização }\end{array}$ & Fragmentação & $2-3$ \\
\hline BG & $\begin{array}{c}\text { Separar } \\
\text { objeto bom e } \\
\text { mau } \\
\end{array}$ & $\begin{array}{c}\text { Solidão, } \\
\text { aniquilamento }\end{array}$ & $\begin{array}{c}\text { Identificação } \\
\text { projetiva }\end{array}$ & $\begin{array}{c}\text { Morte, } \\
\text { desaparecimento } \\
\text { do self }\end{array}$ & $3-4$ \\
\hline $\mathrm{C} 2$ & $\begin{array}{c}\text { Proteger do } \\
\text { aniquilamento }\end{array}$ & $\begin{array}{l}\text { Ansiedade } \\
\text { persecutória }\end{array}$ & $\begin{array}{l}\text { Negação, } \\
\text { paralisação }\end{array}$ & $\begin{array}{c}\text { Morte, } \\
\text { desaparecimento }\end{array}$ & 3 \\
\hline $\mathrm{Br}$ & $\begin{array}{c}\text { Proteger do } \\
\text { aniquilamento }\end{array}$ & $\begin{array}{l}\text { Solidão, } \\
\text { angústia }\end{array}$ & $\begin{array}{l}\text { Introjeção do } \\
\text { bom objeto }\end{array}$ & $\begin{array}{c}\text { Perda e } \\
\text { elaboração do } \\
\text { luto }\end{array}$ & $4-5$ \\
\hline & & & & & $\begin{array}{c}\mathrm{N}=17-20 \\
\text { Média }=3-3,5\end{array}$ \\
\hline
\end{tabular}

Aspectos manifestos: homem, sombra, lugar estranho, nuvens escuras (A1); pessoas, montanha (AG); pessoa, criança, altar, igreja (B3); pessoas, homem sozinho, igreja (separar objetos bom e mau); sombra de pessoas, túmulo, entrada de lugar ruim (C2); papel em branco (Branca). 
Análise: a situação nova é perturbadora (A1), a sombra de um homem aparece (apenas sombra, o homem desaparece na cena). Coloca-se diante de sua solidão de "braços cruzados, sem ação e triste”.

Nega situação triangular em B3 demonstrando ansiedade elevada (negou o terceiro que espia) e elaborando história de um par. Encerra rapidamente a narrativa devido a presença de intensa ansiedade persecutória.

Impedido de sentir depressivamente a situação imposta em AG e manifesta ansiedade confusional: as pessoas são transformadas em montanhas e caminha para elaboração melancólica com mobilização de defesas maníacas (coisificação, desumanização).

Cita o personagem excluído do grupo BG. Apresenta recursos internos diante da reintegração ao meio com estímulo (reza) para enfrentamento de adversidades. Capacidade de tolerar o percurso sozinho e retorna ao grupo para se sentir seguro nesta caminhada.

O personagem desaparece e é transformado em sombra (C2) que caminha para um túmulo. É portador de fantasias de fracasso de reparação e desesperança. Dificuldade para elaborar situação depressiva com presença de angústia persecutória.

Manifesta necessidade de recomeçar a partir deste momento (Branca), faz paralelo com folha em branco onde algo novo será escrito. Desejo de proteção do objeto e medo da solidão. A elaboração depressiva supõe aceitação da condição de saúde / doença atual.

Tendência adaptativa com resultante negativa. Mostra capacidade de elaboração depressiva (condição para iniciar tratamento e aceitar ajuda).

\section{- AVALIAÇÃO MULTIAXIAL - EIXO V - DSM-IV}

Escala de Avaliação Global do Funcionamento (AGF) - Pontuação: 63

Geralmente funciona bem, com relacionamentos interpessoais significativos. Humor algo depressivo. 


\section{PACIENTE 6}

Idade: 66 anos sexo: feminino

HD: IC (Insuficiência Cardíaca)

Classe Funcional NYHA: CF II

- ANÁLISE E INTERPRETAÇÃO DO TRO:

Quadro 16. Avaliação das lâminas - paciente 6 do grupo B:

\begin{tabular}{|c|c|c|c|c|c|}
\hline & \multicolumn{3}{|c|}{ STID } & \multirow{2}{*}{$\begin{array}{c}\text { Fantasia } \\
\text { Inconsciente } \\
\text { Dominante }\end{array}$} & \multirow[b]{2}{*}{ Pontos } \\
\hline & $\begin{array}{c}\text { Desejos } \\
\text { Inconscientes }\end{array}$ & $\begin{array}{c}\text { Medos / } \\
\text { Ansiedades }\end{array}$ & $\begin{array}{c}\text { Mecanismos } \\
\text { de Defesa }\end{array}$ & & \\
\hline A1 & $\begin{array}{c}\text { Paralisar o } \\
\text { objeto ou self }\end{array}$ & $\begin{array}{c}\text { Morte, } \\
\text { aniquilamento }\end{array}$ & Idealização & Aniquilamento & 3 \\
\hline $\mathrm{AG}$ & $\begin{array}{c}\text { Separar } \\
\text { objeto bom e } \\
\text { mau } \\
\end{array}$ & $\begin{array}{l}\text { Culpa parcial } \\
\text { pela destruição }\end{array}$ & $\begin{array}{l}\text { Introjeção do } \\
\text { bom objeto }\end{array}$ & $\begin{array}{c}\text { Perda e } \\
\text { elaboração do } \\
\text { luto } \\
\end{array}$ & $4-5$ \\
\hline B3 & $\begin{array}{c}\text { Separar } \\
\text { objeto bom e } \\
\text { mau }\end{array}$ & $\begin{array}{c}\text { Não ser vista, } \\
\text { notada }\end{array}$ & $\begin{array}{c}\text { Identificação } \\
\text { projetiva e } \\
\text { introjetiva }\end{array}$ & Separação & 3 \\
\hline BG & $\begin{array}{c}\text { Proteger do } \\
\text { aniquilamento }\end{array}$ & Estar só & $\begin{array}{c}\text { Introjeção do } \\
\text { bom objeto }\end{array}$ & $\begin{array}{c}\text { Integração de } \\
\text { partes }\end{array}$ & $4-5$ \\
\hline $\mathrm{C} 2$ & $\begin{array}{c}\text { Fusão, } \\
\text { paralisação }\end{array}$ & Aniquilamento & $\begin{array}{c}\text { Negação, } \\
\text { controle } \\
\text { onipotente }\end{array}$ & Fragmentação & $2-3$ \\
\hline $\mathrm{Br}$ & Reparação & $\begin{array}{c}\text { Angústia } \\
\text { depressiva }\end{array}$ & $\begin{array}{l}\text { Introjeção do } \\
\text { bom objeto }\end{array}$ & $\begin{array}{c}\text { Perda e } \\
\text { elaboração do } \\
\text { luto }\end{array}$ & $4-5$ \\
\hline & & & & & $\begin{array}{l}\mathrm{N}=20-24 \\
\text { Média }=4\end{array}$ \\
\hline
\end{tabular}

Aspectos manifestos: homens, casa (A1); pessoas, muro (AG); pessoas, espião, quarto (B3); pessoas, quarto, porta, calçada de casa (BG); pessoas, paciente, pesquisadora, conteúdo de realidade negado $(\mathrm{C} 2)$; paciente, pesquisadora (Branca).

Análise: ampara-se na situação nova e angustiante de teste projetando um homem parado entre dois outros que o observam / sustentam (A1). Apesar de serem inseridos na cena, 
estão imóveis, assim como o do centro que "não faz nada e fica com os braços cruzados juntos ao corpo, com certa preocupação”. Vislumbra situação triangular narrando um personagem à espreita como espião (observador), presente diante de um par unido e capaz de tolerar estar fora desta relação.

Contrapões dois grupos de pessoas (três em pé, sentindo medo e conversando, e três sentados), demonstrando aspectos do ego que foram destruídos e aqueles que são reparadores. Parte do ego sofre pelo objeto perdido (pessoas em pé que conversam e sentem medo).

Cita personagem afastado do grupo em BG, porém o apresenta com distanciamento suportável e fantasia de continente estável (casa). Apesar de afastado de seus pares, parece preparado para se juntar a eles ao entrar em casa, o que mostra recursos internos importantes para a reintegração ao meio.

Nega conteúdo mobilizado em C2 referente às perdas, dificultando o enfrentamento do luto. Repara ao final, narrando / citando personagem que se aproxima para ajudar (portador de fantasias reparatórias). Coloca-se como aquela que precisa de apoio e insere a pesquisadora na história como a que é capaz de oferecer esta ajuda. Demonstra que o teste lhe proporcionou um momento de continência de suas identificações projetivas. Foram mobilizados afetos com a situação de perda (Branca); mostra condições de atingir elaboração depressiva aceitando sofrimento e ajuda.

Tendência adaptativa podendo alcançar resultante positiva.

\section{- AVALIAÇÃO MULTIAXIAL - EIXO V - DSM-IV}

Escala de Avaliação Global do Funcionamento (AGF) - Pontuação: 71

Sintomas temporários, reações previsíveis às situações estressoras. Possui relacionamentos interpessoais significativos. 


\section{PACIENTE 7}

Idade: 64 anos sexo: masculino

HD: IC (Insuficiência Cardíaca)

Classe Funcional NYHA: CF II

- ANÁLISE E INTERPRETAÇÃO DO TRO:

Quadro 17. Avaliação das lâminas - paciente 7 do grupo B:

\begin{tabular}{|c|c|c|c|c|c|}
\hline & \multicolumn{3}{|c|}{ STID } & \multirow{2}{*}{$\begin{array}{c}\text { Fantasia } \\
\text { Inconsciente } \\
\text { Dominante }\end{array}$} & \multirow[b]{2}{*}{ Pontos } \\
\hline & $\begin{array}{c}\text { Desejos } \\
\text { Inconscientes }\end{array}$ & $\begin{array}{c}\text { Medos / } \\
\text { Ansiedades }\end{array}$ & $\begin{array}{l}\text { Mecanismos } \\
\text { de Defesa }\end{array}$ & & \\
\hline A1 & $\begin{array}{l}\text { Proteger do } \\
\text { aniquilamento }\end{array}$ & Morte, solidão & $\begin{array}{c}\text { Identificação } \\
\text { projetiva }\end{array}$ & $\begin{array}{c}\text { Desaparecimento } \\
\text { do self }\end{array}$ & 3 \\
\hline AG & $\begin{array}{l}\text { Fusão com } \\
\text { objeto }\end{array}$ & $\begin{array}{c}\text { Medo de } \\
\text { progredir, } \\
\text { aniquilamento }\end{array}$ & $\begin{array}{c}\text { Controle } \\
\text { onipotente }\end{array}$ & Fragmentação & 2 \\
\hline B3 & $\begin{array}{l}\text { Fusão com } \\
\text { objeto }\end{array}$ & $\begin{array}{l}\text { Ambivalência, } \\
\text { ansiedade }\end{array}$ & $\begin{array}{l}\text { Negação, } \\
\text { clivagem }\end{array}$ & $\begin{array}{c}\text { Fusão, } \\
\text { aglutinação }\end{array}$ & 2 \\
\hline BG & $\begin{array}{c}\text { Separar } \\
\text { objeto bom e } \\
\text { mau }\end{array}$ & $\begin{array}{c}\text { Solidão, } \\
\text { desvalorização, } \\
\text { inveja }\end{array}$ & $\begin{array}{c}\text { Identificação } \\
\text { projetiva e } \\
\text { introjetiva }\end{array}$ & Separação & 3 \\
\hline $\mathrm{C} 2$ & $\begin{array}{c}\text { Paralisar o } \\
\text { objeto ou self }\end{array}$ & $\begin{array}{l}\text { Angústia } \\
\text { persecutória }\end{array}$ & $\begin{array}{c}\text { Negação / } \\
\text { escotomização }\end{array}$ & Fragmentação & $2-3$ \\
\hline $\mathrm{Br}$ & $\begin{array}{c}\text { Separar } \\
\text { objeto bom e } \\
\text { mau }\end{array}$ & $\begin{array}{l}\text { Angústia } \\
\text { depressiva }\end{array}$ & $\begin{array}{l}\text { Introjeção do } \\
\text { bom objeto }\end{array}$ & $\begin{array}{c}\text { Perda e } \\
\text { elaboração do } \\
\text { luto }\end{array}$ & $4-5$ \\
\hline & & & & & $\begin{array}{c}\mathrm{N}=16-18 \\
\text { Média }=2,5-3\end{array}$ \\
\hline
\end{tabular}

Aspectos manifestos: ser humano, nuvem negra (A1); menino, golfinhos, conteúdo de realidade negado (AG); casal, criança, porta (B3); pessoas, amigo, templo, igreja (BG); pessoa, desenho, alpendre, planta, local ermo, casa abandonada (C2); paciente, pesquisadora (Branca). 
Análise: é colocado diante de sua solidão em A1. Refere ser este um momento assustador e identifica-se projetivamente com o personagem. Afirma que, se fosse ele na cena, estaria preocupado e com medo deste lugar.

A situação triangular é negada em B3, demonstrando ansiedade elevada, temor às identificações projetivas e dificuldade para reintrojeções.

Defende-se maniacamente do conteúdo mobilizado em AG e não sente depressivamente a situação de perda colocada pela lâmina. Não aparecem culpa ou afetos relacionados à própria depressão.

Refere exclusão não apenas espacial de um personagem em relação a um grupo de pares, com fantasia de continente estável (igreja). O “amigo" está isolado dos demais por estar triste e se sentindo sozinho.

Omite um dos personagens da cena em C2 e aparecem fenômenos confusionais e defesas maníacas devido a ansiedade excessiva.

Sente-se angustiado diante da lâmina Branca. Demonstra relação transferencial de dependência estabelecida com a pesquisadora, porém elabora depressivamente aceitando sua condição de sofrimento / doença e afirmando sua capacidade de receber e aceitar ajuda (tratamento).

Equilíbrio não mantido com predomínio de ansiedade. No entanto, apresenta condições para possível adaptação.

\section{- AVALIAÇÃO MULTIAXIAL - EIXO V - DSM-IV}

Escala de Avaliação Global do Funcionamento (AGF) - Pontuação: 60

Apresenta sintomas moderados com distanciamento afetivo e intensa ansiedade, com certa dificuldade no funcionamento social. 


\section{PACIENTE 8}

Idade: 76 anos sexo: feminino

HD: HAS - IC (Doença Cardíaca Hipertensiva com Insuficiência Cardíaca)

Classe Funcional NYHA: CF I

- ANÁLISE E INTERPRETAÇÃO DO TRO:

Quadro 18. Avaliação das lâminas - paciente 8 do grupo B:

\begin{tabular}{|c|c|c|c|c|c|}
\hline & \multicolumn{3}{|c|}{ STID } & \multirow{2}{*}{$\begin{array}{c}\text { Fantasia } \\
\text { Inconsciente } \\
\text { Dominante }\end{array}$} & \multirow[b]{2}{*}{ Pontos } \\
\hline & $\begin{array}{c}\text { Desejos } \\
\text { Inconscientes }\end{array}$ & $\begin{array}{c}\text { Medos / } \\
\text { Ansiedades }\end{array}$ & $\begin{array}{l}\text { Mecanismos } \\
\text { de Defesa }\end{array}$ & & \\
\hline A1 & $\begin{array}{c}\text { Fusão com } \\
\text { objeto amado }\end{array}$ & $\begin{array}{c}\text { Angústia } \\
\text { persecutória }\end{array}$ & $\begin{array}{c}\text { Identificação } \\
\text { projetiva, } \\
\text { idealização }\end{array}$ & $\begin{array}{l}\text { Destruição do } \\
\text { objeto }\end{array}$ & 2 \\
\hline $\mathrm{AG}$ & $\begin{array}{c}\text { Paralisar o } \\
\text { objeto ou self }\end{array}$ & $\begin{array}{c}\text { Culpa } \\
\text { persecutória }\end{array}$ & Idealização & Fragmentação & $2-3$ \\
\hline B3 & $\begin{array}{c}\text { Fusão, } \\
\text { aglutinação }\end{array}$ & $\begin{array}{l}\text { Persecutoriedade, } \\
\text { ansiedade } \\
\text { confusional }\end{array}$ & $\begin{array}{c}\text { Controle } \\
\text { onipotente }\end{array}$ & Fusão & $1-2$ \\
\hline BG & $\begin{array}{l}\text { Fusão, } \\
\text { paralisar } \\
\text { objeto }\end{array}$ & $\begin{array}{l}\text { Angústia } \\
\text { persecutória }\end{array}$ & $\begin{array}{c}\text { Controle, } \\
\text { imobilização, } \\
\text { escotomização }\end{array}$ & $\begin{array}{c}\text { Morte, } \\
\text { desaparecimento } \\
\text { do self }\end{array}$ & 2 \\
\hline $\mathrm{C} 2$ & $\begin{array}{c}\text { Paralisar o } \\
\text { objeto ou self }\end{array}$ & $\begin{array}{c}\text { Angústia } \\
\text { persecutória }\end{array}$ & $\begin{array}{l}\text { Controle de } \\
\text { objetos, } \\
\text { imobilização }\end{array}$ & Fragmentação & $1-2$ \\
\hline $\mathrm{Br}$ & Dependência & $\begin{array}{c}\text { Morte, } \\
\text { aniquilamento }\end{array}$ & $\begin{array}{l}\text { Controle } \\
\text { onipotente }\end{array}$ & Fragmentação & $1-2$ \\
\hline & & & & & $\begin{array}{c}\mathrm{N}=9-13 \\
\text { Média }=2\end{array}$ \\
\hline
\end{tabular}

Aspectos manifestos: homem, lugar com flores (A1); família, outro mundo (AG); Jesus Cristo, conteúdo de realidade negado (B3); pessoas, casa, igreja (BG); genro, jardim, porta (C2); paciente, pesquisadora (Branca). 
Análise: mostra perturbação importante diante da primeira lâmina (A1), recordando-se do filho falecido. Insere o filho como personagem que a observa, está "triste, pensativo $e$ sozinho" em um lugar com flores. Conteúdo de perda mobilizado e identifica-se projetivamente com o personagem.

Ignora situação triangular devido excessiva ansiedade e nega a presença do par, inserindo a figura de Jesus Cristo na lâmina apresentada (B3).

Idealização extrema em AG com a criação de outro mundo habitado por sua família, que está "feliz e sossegada”. Sentimento de culpa persecutória e alguns bloqueios devido a impossibilidade de elaborar a situação de perda.

Faz referência ao grupo (BG), mas nega personagem excluído devido intensa ansiedade gerada pelo conteúdo da lâmina.

Omite personagem acamado (C2) demonstrando dificuldade para elaboração do processo de luto (aceitação da perda). Aparecem defesas maníacas: negação e controle onipotente.

Onipotentemente controla conteúdo mobilizado pela última lâmina (Branca), referindo estar "feliz por conversar" e demonstra ansiedade importante com o encerramento (momento da separação).

\section{- AVALIAÇÃO MULTIAXIAL - EIXO V - DSM-IV}

Escala de Avaliação Global do Funcionamento (AGF) - Pontuação: 51

Sintomas moderados e dificuldade no funcionamento social. Apresenta ansiedade importante. 


\section{PACIENTE 9}

Idade: 67 anos sexo: feminino

HD: ICO (Insuficiência Coronariana)

Classe Funcional NYHA: CF II

- ANÁLISE E INTERPRETAÇÃO DO TRO:

Quadro 19. Avaliação das lâminas - paciente 9 do grupo B:

\begin{tabular}{|c|c|c|c|c|c|}
\hline & \multicolumn{3}{|c|}{ STID } & \multirow{2}{*}{$\begin{array}{c}\text { Fantasia } \\
\text { Inconsciente } \\
\text { Dominante }\end{array}$} & \multirow[b]{2}{*}{ Pontos } \\
\hline & $\begin{array}{c}\text { Desejos } \\
\text { Inconscientes }\end{array}$ & $\begin{array}{c}\text { Medos / } \\
\text { Ansiedades }\end{array}$ & $\begin{array}{c}\text { Mecanismos } \\
\text { de Defesa }\end{array}$ & & \\
\hline A1 & $\begin{array}{c}\text { Separar } \\
\text { objetos bom e } \\
\text { mau }\end{array}$ & $\begin{array}{l}\text { Angústia } \\
\text { depressiva }\end{array}$ & $\begin{array}{c}\text { Identificação } \\
\text { projetiva }\end{array}$ & Proteger o self & $4-5$ \\
\hline $\mathrm{AG}$ & $\begin{array}{l}\text { Reparar } \\
\text { objetos }\end{array}$ & $\begin{array}{l}\text { Angústia } \\
\text { depressiva }\end{array}$ & $\begin{array}{l}\text { Introjeção do } \\
\text { bom objeto }\end{array}$ & $\begin{array}{c}\text { Perda e } \\
\text { elaboração do } \\
\text { luto }\end{array}$ & $4-5$ \\
\hline B3 & $\begin{array}{l}\text { Proteger do } \\
\text { aniquilamento }\end{array}$ & $\begin{array}{l}\text { Aniquilamento, } \\
\text { solidão }\end{array}$ & $\begin{array}{c}\text { Identificação } \\
\text { projetiva }\end{array}$ & Reparação & 4 \\
\hline $\mathrm{BG}$ & $\begin{array}{l}\text { Separar } \\
\text { objetos }\end{array}$ & $\begin{array}{l}\text { Medo de } \\
\text { progredir }\end{array}$ & $\begin{array}{c}\text { Identificação } \\
\text { projetiva }\end{array}$ & Separação & 3 \\
\hline $\mathrm{C} 2$ & $\begin{array}{l}\text { Reparação do } \\
\text { objeto }\end{array}$ & $\begin{array}{c}\text { Angústia } \\
\text { depressiva }\end{array}$ & $\begin{array}{l}\text { Introjeção do } \\
\text { bom objeto }\end{array}$ & $\begin{array}{c}\text { Perda e } \\
\text { elaboração do } \\
\text { luto }\end{array}$ & $4-5$ \\
\hline $\mathrm{Br}$ & $\begin{array}{l}\text { Restaurar o } \\
\text { objeto }\end{array}$ & $\begin{array}{l}\text { Angústia } \\
\text { depressiva }\end{array}$ & $\begin{array}{l}\text { Reparaçãa } \\
\text { maníaca }\end{array}$ & $\begin{array}{c}\text { Elaboração do } \\
\text { luto }\end{array}$ & 5 \\
\hline & & & & & $\begin{array}{c}\mathrm{N}=24-27 \\
\text { Média }=4,5\end{array}$ \\
\hline
\end{tabular}

Aspectos manifestos: homem, paciente, espaço interno (A1); pessoas, entes queridos, lugar desconhecido (AG); criança, família, netos, quarto (B3); pessoas indecisas, porta da liberdade (BG); paciente, filhos, porta, quarto (C2); pesquisadora, portas (Branca). 
Análise: identifica-se projetivamente com personagem em A1 que, diante da situação nova / desconhecida apresentada, busca contato com o mundo interno e reflexão.

Sentimento de solidão e medo do aniquilamento são aflorados em B3, que levam à criação de uma imagem de criança sozinha, escondida e com medo. Pensa nos netos e em como se sentiram com a separação dos pais.

Recorda-se de suas perdas em AG, remonta situação de luto por seus entes queridos que a esperam em algum lugar, ou a observam. Presença de angústia depressiva e culpa.

Frequentemente (BG, C2, Branca) cita uma "porta” como metáfora para o "seguir adiante”. Mostra-se paralisada na situação apresentada em BG, frente a uma porta que lhe causa angústia, sentimento de indecisão.

Visualiza porta que levava ao quarto dos filhos em C2. É mobilizado o sentimento de angústia depressiva (culpa) e tentativa de elaboração do luto.

Acredita em um recomeço “mais saudável” (Branca), apresenta recursos internos para enfrentamento das perdas e da condição atual de saúde / doença.

Predomínio de relações de objeto totais. Tendência adaptativa com resultante positiva.

\section{- AVALIAÇÃO MULTIAXIAL - EIXO V - DSM-IV}

Escala de Avaliação Global do Funcionamento (AGF) - Pontuação: 61

Sintomas como humor deprimido, insônia, enxaqueca. Socialmente, mantém bom funcionamento com relacionamentos interpessoais significativos. Histórico de perdas significativas. 


\section{PACIENTE 10}

Idade: 39 anos sexo: feminino

HD: IC (Insuficiência Cardíaca)

Classe Funcional NYHA: CF II

- ANÁLISE E INTERPRETAÇÃO DO TRO:

Quadro 20. Avaliação das lâminas - paciente 10 do grupo B:

\begin{tabular}{|c|c|c|c|c|c|}
\hline & \multicolumn{3}{|c|}{ STID } & \multirow{2}{*}{$\begin{array}{c}\text { Fantasia } \\
\text { Inconsciente } \\
\text { Dominante }\end{array}$} & \multirow[b]{2}{*}{ Pontos } \\
\hline & $\begin{array}{c}\text { Desejos } \\
\text { Inconscientes }\end{array}$ & $\begin{array}{c}\text { Medos / } \\
\text { Ansiedades }\end{array}$ & $\begin{array}{c}\text { Mecanismos } \\
\text { de Defesa }\end{array}$ & & \\
\hline A1 & $\begin{array}{c}\text { Paralisar o } \\
\text { objeto ou self }\end{array}$ & $\begin{array}{l}\text { Ansiedade } \\
\text { confusional }\end{array}$ & $\begin{array}{c}\text { Paralisação, } \\
\text { negação }\end{array}$ & Paralisação & $2-3$ \\
\hline $\mathrm{AG}$ & $\begin{array}{c}\text { Fusão / } \\
\text { aglutinação }\end{array}$ & $\begin{array}{c}\text { Angústia, } \\
\text { persecutoriedade }\end{array}$ & $\begin{array}{l}\text { Negação } \\
\text { onipotente }\end{array}$ & Paralisação & $2-3$ \\
\hline B3 & $\begin{array}{l}\text { Ser cuidada, } \\
\text { fusão }\end{array}$ & $\begin{array}{l}\text { Ambivalência, } \\
\text { aniquilamento }\end{array}$ & Idealização & $\begin{array}{c}\text { Fusão / } \\
\text { aglutinação }\end{array}$ & $2-3$ \\
\hline BG & $\begin{array}{c}\text { Paralisar o } \\
\text { objeto ou self }\end{array}$ & $\begin{array}{c}\text { Medo do } \\
\text { aniquilamento }\end{array}$ & Idealização & $\begin{array}{l}\text { Destruição do } \\
\text { objeto }\end{array}$ & 3 \\
\hline $\mathrm{C} 2$ & $\begin{array}{l}\text { Fusão com o } \\
\text { objeto }\end{array}$ & $\begin{array}{l}\text { Ausência de } \\
\text { sentido na } \\
\text { realidade }\end{array}$ & $\begin{array}{l}\text { Negação / } \\
\text { clivagem }\end{array}$ & $\begin{array}{c}\text { Desaparecimento } \\
\text { do self }\end{array}$ & 2 \\
\hline $\mathrm{Br}$ & $\begin{array}{l}\text { Fusão com o } \\
\text { objeto amado }\end{array}$ & Estar só & Idealização & Fusão & 3 \\
\hline & & & & & $\begin{array}{c}\mathrm{N}=14-17 \\
\text { Média }=2,5-3\end{array}$ \\
\hline
\end{tabular}

Aspectos manifestos: homem pensativo, roça (A1); mulheres, rio (AG); homem, bebê, médico, quarto de hospital (B3); pessoas, criança, mulher, janela, igreja (BG); mulher, cozinheira, roça, fogão à lenha (C2); Deus, céu, nuvens, ar (Branca). 
Análise: situação nova incita perturbações manifestadas na paralisação do personagem em A1 (apesar de pensar). A lâmina gera ansiedade confusional observada na narração / descrição elaborada a partir dos aspectos mobilizados.

Nega situação triangular em B3 fusionando-se com o objeto. Apresenta angústia de morte e desejo de ser cuidada.

Onipotentemente, nega o conteúdo de realidade em AG, apresenta narrativa empobrecida, mostra incômodo, angústia (persecutoriedade) e paralisa o personagem.

Idealiza momento de oração em igreja (BG) por medo do aniquilamento (pessoas rezam com mulher e criança).

Nega cenário apresentado em $\mathrm{C} 2$, transforma quarto em cozinha com fogão à lenha e exclui não cita pessoa na cama. Apresenta mecanismo de clivagem entre a realidade do mundo interno e externo com desejo de se fundir ao objeto (e, consequentemente, desaparecer).

A lâmina Branca mobiliza aspectos relacionados aos recursos disponíveis para lidar com a doença, com os problemas e com o futuro. Idealiza atribuindo este cuidado à Deus, afirmando que, assim "tudo ficará bem, tudo ficará bom”.

Distanciamento afetivo e cisão como mecanismos frequentemente presentes na narrativa. Predomínio de ansiedade com relações e resultante negativas.

\section{- AVALIAÇÃO MULTIAXIAL - EIXO V - DSM-IV}

Escala de Avaliação Global do Funcionamento (AGF) - Pontuação: 40

Algum prejuízo no teste de realidade, ausência de sentido na realidade (clivagem entre realidade interna e externa). 


\section{GRUPO C}

\section{PACIENTE 1}

Idade: 63 anos sexo: feminino

HD: IAM SST (Infarto Agudo do Miocárdio com Supradesnivelamento de Seguimento ST)

Classe Funcional NYHA: CF III

\section{- ANÁLISE E INTERPRETAÇÃO DO TRO:}

Quadro 21. Avaliação das lâminas - paciente 1 do grupo C:

\begin{tabular}{|c|c|c|c|c|c|}
\hline & \multicolumn{3}{|c|}{ STID } & \multirow{2}{*}{$\begin{array}{c}\text { Fantasia } \\
\text { Inconsciente } \\
\text { Dominante }\end{array}$} & \multirow[b]{2}{*}{ Pontos } \\
\hline & $\begin{array}{c}\text { Desejos } \\
\text { Inconscientes }\end{array}$ & $\begin{array}{c}\text { Medos / } \\
\text { Ansiedades }\end{array}$ & $\begin{array}{l}\text { Mecanismos } \\
\text { de Defesa }\end{array}$ & & \\
\hline A1 & $\begin{array}{c}\text { Paralisar o } \\
\text { objeto ou self }\end{array}$ & Ambivalência & $\begin{array}{l}\text { Idealização, } \\
\text { negação }\end{array}$ & Paralisação & $2-3$ \\
\hline AG & $\begin{array}{c}\text { Separar } \\
\text { objeto bom e } \\
\text { mau }\end{array}$ & $\begin{array}{l}\text { Aniquilamento, } \\
\text { persecutoriedade }\end{array}$ & $\begin{array}{c}\text { Idealização, } \\
\text { controle } \\
\text { onipotente }\end{array}$ & Separação & $2-3$ \\
\hline B3 & $\begin{array}{l}\text { Fusão com o } \\
\text { objeto amado }\end{array}$ & $\begin{array}{c}\text { Inveja, } \\
\text { aniquilamento }\end{array}$ & $\begin{array}{c}\text { Controle } \\
\text { onipotente, } \\
\text { negação }\end{array}$ & Fusão & $1-2$ \\
\hline BG & $\begin{array}{c}\text { Paralisar o } \\
\text { objeto ou self }\end{array}$ & Inveja & $\begin{array}{l}\text { Controle, } \\
\text { imobilização }\end{array}$ & $\begin{array}{c}\text { Desaparecimento } \\
\text { do self }\end{array}$ & $1-2$ \\
\hline $\mathrm{C} 2$ & $\begin{array}{l}\text { Destruir o } \\
\text { objeto }\end{array}$ & $\begin{array}{c}\text { Ansiedade } \\
\text { confusional, } \\
\text { ambivalência }\end{array}$ & Negação & $\begin{array}{l}\text { Destruição do } \\
\text { objeto }\end{array}$ & 2 \\
\hline $\mathrm{Br}$ & $\begin{array}{l}\text { Reparar o } \\
\text { objeto }\end{array}$ & $\begin{array}{l}\text { Angústia } \\
\text { depressiva }\end{array}$ & Reparação & $\begin{array}{c}\text { Perda e } \\
\text { elaboração do } \\
\text { luto }\end{array}$ & $4-5$ \\
\hline & & & & & $\begin{array}{c}\mathrm{N}=12-17 \\
\text { Média }=2-2,5\end{array}$ \\
\hline
\end{tabular}

Aspectos manifestos: homem, marido, criança, mulher, quadro (A1); almas, pessoas, pesadelo (AG); casal, figura (B3); pessoas, noivos, festa, clube (BG); velho, pessoa (C2); paciente, netos, marido, amigos (Branca) 
Análise: apresenta o temor ante ao desconhecido (A1), visualizando uma figura masculina sem rumo que é observada por uma criança e uma mulher, descrevendo uma situação regressiva de dependência.

O terceiro da relação triangular (B3) é projetado como "figura", objeto inanimado, demonstrando sua dificuldade em aceitar a exclusão devido à ansiedade elevada.

Elaboração maníaca identificada (AG) com predomínio de idealização com “almas sofredoras que precisam de ajuda". Repara, ao final, intitulando a história de "Pesadelo", contrapondo a idéia inicial.

Nega a situação de exclusão imposta em BG, com fantasias de continente estável. Inveja o que é sadio e está de fora e controla onipotentemente o conteúdo da lâmina.

Defende-se maniacamente produzindo um personagem portador de conteúdos destrutivos, ameaçadores (C2). Distancia-se afetivamente, cita o personagem acamado, mas

afirma que "não tem certeza do que viu”, negando a realidade da morte presente na lâmina.

Afetos mobilizados referentes às perdas e possibilidade de recuperação (Branca). Encontra na família o suporte para o enfrentamento da doença e repara a destruição causada anteriormente.

Poderá alcançar adaptação. No momento, há predomínio de ansiedade e não mantém o equilíbrio adaptativo.

\section{- AVALIAÇÃO MULTIAXIAL - EIXO V - DSM-IV}

Escala de Avaliação Global do Funcionamento (AGF) - Pontuação: 45

Apresenta sintomas moderados, como fala circunstancial, porém com algum prejuízo no teste de realidade e no humor. 


\section{PACIENTE 2}

Idade: 73 anos sexo: masculino

HD: IAM SST (Infarto Agudo do Miocárdio com Supradesnivelamento de Seguimento ST) SCA (Síndrome Coronariana Aguda)

Classe Funcional NYHA: CF III

- ANÁLISE E INTERPRETAÇÃO DO TRO:

Quadro 22. Avaliação das lâminas - paciente 2 do grupo C:

\begin{tabular}{|c|c|c|c|c|c|}
\hline & \multicolumn{3}{|c|}{ STID } & \multirow{2}{*}{$\begin{array}{c}\text { Fantasia } \\
\text { Inconsciente } \\
\text { Dominante }\end{array}$} & \multirow[b]{2}{*}{ Pontos } \\
\hline & $\begin{array}{c}\text { Desejos } \\
\text { Inconscientes }\end{array}$ & $\begin{array}{c}\text { Medos / } \\
\text { Ansiedades }\end{array}$ & $\begin{array}{l}\text { Mecanismos } \\
\text { de Defesa }\end{array}$ & & \\
\hline A1 & Dependência & $\begin{array}{c}\text { Solidão, } \\
\text { aniquilamento }\end{array}$ & $\begin{array}{c}\text { Identificação } \\
\text { projetiva }\end{array}$ & $\begin{array}{l}\text { Destruição do } \\
\text { objeto }\end{array}$ & 2 \\
\hline AG & $\begin{array}{c}\text { Paralisar o } \\
\text { objeto ou self }\end{array}$ & $\begin{array}{c}\text { Progredir, } \\
\text { aniquilamento }\end{array}$ & Escotomização & $\begin{array}{c}\text { Desaparecimento } \\
\text { do self }\end{array}$ & 2 \\
\hline B3 & Dependência & $\begin{array}{l}\text { Desesperança, } \\
\text { solidão, inveja }\end{array}$ & $\begin{array}{l}\text { Escotomização } \\
\text { identificação } \\
\text { projetiva }\end{array}$ & $\begin{array}{l}\text { Destruição do } \\
\text { objeto }\end{array}$ & $1-2$ \\
\hline BG & $\begin{array}{c}\text { Separar } \\
\text { objeto bom e } \\
\text { mau }\end{array}$ & $\begin{array}{c}\text { Angústia, } \\
\text { persecutoriedade }\end{array}$ & $\begin{array}{c}\text { Identificação } \\
\text { projetiva e } \\
\text { introjetiva }\end{array}$ & Morte & 3 \\
\hline $\mathrm{C} 2$ & $\begin{array}{c}\text { Reparar } \\
\text { objeto }\end{array}$ & $\begin{array}{l}\text { Angústia } \\
\text { depressiva }\end{array}$ & Reparação & $\begin{array}{c}\text { Perda e } \\
\text { elaboração do } \\
\text { luto }\end{array}$ & $5-6$ \\
\hline $\mathrm{Br}$ & $\begin{array}{l}\text { Ausência de } \\
\text { sentido real }\end{array}$ & $\begin{array}{l}\text { Persecutoriedade, } \\
\text { aniquilamento }\end{array}$ & Paralisação & $\begin{array}{l}\text { Destruição do } \\
\text { objeto }\end{array}$ & 2 \\
\hline & & & & & $\begin{array}{c}\mathrm{N}=15-18 \\
\text { Média }=2,5-3\end{array}$ \\
\hline
\end{tabular}

Aspectos manifestos: homem, pessoa, além (A1); pinguins, mar (AG); adulto, criança, hospital (B3), pessoas, assistência médica (BG); enfermeira, pessoa, médico, cama (C2); folha em branco (Branca). 
Análise: coloca-se diante da sua solidão (A1) e traz contexto de morte visualizando uma figura masculina no além, que não pode ser ajudado porque a pessoa que o acompanha “está falecida”. O homem está sozinho e enfrenta a solidão (doença) com oração.

Nega o terceiro da situação triangular (B3). O par é projetado como o médico que cuida da criança porque "a criança ainda tem perspectiva de vida". Desesperança e ansiedade elevadas.

Dificuldade para elaborar o clima depressivo (AG), transforma imagem em pinguins à procura de um caminho. Desloca o drama fundamentalmente humano para uma paisagem onde a dor é tolerada (buscam um caminho em seu habitat, o caminho para o mar).

Admite a situação de exclusão imposta (BG) sem atribuir aspectos de autoridade ao personagem isolado ou ao grupo de pares. Enfrentam a mesma espera: a espera pelo socorro. Sentimento significativo de angústia.

O personagem na cama é citado (C2) e aquele que se aproxima é portador de fantasias reparatórias (vem para ajudar, cuidar). São mobilizados sentimentos depressivos com elaboração do luto.

Distancia-se afetivamente (Branca) e ignora possibilidade de elaboração depressiva devido à intensa ansiedade diante da última lâmina do teste.

Tendência adaptativa com resultante negativa.

\section{- AVALIAÇÃO MULTIAXIAL - EIXO V - DSM-IV}

Escala de Avaliação Global do Funcionamento (AGF) - Pontuação: 51

Alguns sintomas moderados com certa dificuldade no funcionamento social / ocupacional. 


\section{PACIENTE 3}

Idade: 56 anos sexo: masculino

HD: ICC (Insuficiência Cardíaca Crônica) - SCA (Síndrome Coronariana Aguda)

Classe Funcional NYHA: CF III

- ANÁLISE E INTERPRETAÇÃO DO TRO:

Quadro 23. Avaliação das lâminas - paciente 3 do grupo C:

\begin{tabular}{|c|c|c|c|c|c|}
\hline & \multicolumn{3}{|c|}{ STID } & \multirow{2}{*}{$\begin{array}{c}\text { Fantasia } \\
\text { Inconsciente } \\
\text { Dominante }\end{array}$} & \multirow[b]{2}{*}{ Pontos } \\
\hline & $\begin{array}{c}\text { Desejos } \\
\text { Inconscientes }\end{array}$ & $\begin{array}{c}\text { Medos / } \\
\text { Ansiedades }\end{array}$ & $\begin{array}{c}\text { Mecanismos } \\
\text { de Defesa }\end{array}$ & & \\
\hline A1 & $\begin{array}{l}\text { Ser visto, } \\
\text { notado }\end{array}$ & $\begin{array}{c}\text { Solidão, } \\
\text { abandono }\end{array}$ & $\begin{array}{l}\text { Introjeção do } \\
\text { bom objeto }\end{array}$ & Separação & $3-4$ \\
\hline $\mathrm{AG}$ & $\begin{array}{c}\text { Separar } \\
\text { objeto bom e } \\
\text { mau }\end{array}$ & $\begin{array}{l}\text { Ambivalência, } \\
\text { ansiedade } \\
\text { confusional }\end{array}$ & $\begin{array}{c}\text { Controle de } \\
\text { objetos }\end{array}$ & Separação & 2 \\
\hline B3 & $\begin{array}{c}\text { Separar } \\
\text { objeto bom e } \\
\text { mau }\end{array}$ & $\begin{array}{l}\text { Angústia } \\
\text { depressiva }\end{array}$ & $\begin{array}{l}\text { Introjeção do } \\
\text { bom objeto }\end{array}$ & Separação & $4-5$ \\
\hline $\mathrm{BG}$ & $\begin{array}{l}\text { Ser visto, } \\
\text { notado }\end{array}$ & Persecutoriedade & $\begin{array}{c}\text { Identificação } \\
\text { projetiva e } \\
\text { introjetiva }\end{array}$ & Integração & 3 \\
\hline $\mathrm{C} 2$ & $\begin{array}{c}\text { Paralisar o } \\
\text { objeto ou self }\end{array}$ & Ambivalência & $\begin{array}{c}\text { Controle } \\
\text { onipotente, } \\
\text { negação }\end{array}$ & Morte & 2 \\
\hline $\mathrm{Br}$ & $\begin{array}{l}\text { Reparar o } \\
\text { objeto }\end{array}$ & $\begin{array}{l}\text { Angústia } \\
\text { depressiva }\end{array}$ & Reparação & $\begin{array}{c}\text { Perda e } \\
\text { elaboração do } \\
\text { luto }\end{array}$ & 5 \\
\hline & & & & & $\begin{array}{c}\mathrm{N}=19-21 \\
\text { Média }=3,5\end{array}$ \\
\hline
\end{tabular}

Aspectos manifestos: homem, pessoa, conteúdo de realidade negado (A1); pessoas, conteúdo de realidade negado (AG); pessoa, esposa, filho, marido, nega conteúdo de realidade (B3); pessoas, paciente, amigos do paciente, nega conteúdo de realidade (BG); pessoa, mundo (C2); paciente, pessoas, mundo obscuro, parede, degrau (Branca). 
Análise: enfrenta sua solidão projetando em A1 um segundo personagem como aquele que poderá "guiar o homem sem rumo, ajudar, solucionar suas dúvidas", demonstrando o nível da relação transferencial estabelecida com a pesquisadora.

Admite a situação triangular e tolera ficar de fora, apenas observando o casal (B3). Narra um contexto de reunião familiar: há expectativas em relação à presença do outro (valoriza este contato).

Ambivalência em AG nas ondas que "vem e vão", além da presença de ansiedade confusional que indica elaboração maníaca.

Identifica-se projetivamente com o personagem isolado em BG. Enfrenta a situação de exclusão atenuando a ansiedade presente.

Ignora personagem acamado $(\mathrm{C} 2)$ demonstrando ambivalência naquele que está à porta e "não sabe se entra ou não, se vai ou volta". Paralisa o objeto que fica sem ação diante do conteúdo de perda que foi mobilizado.

Descreve a presença de objetos perseguidores que se transformam em reparadores (Branca). Possibilidade de elaboração depressiva. Mostra-se capaz de aceitar o sofrimento, o que é precondição para o início de um tratamento (para a manutenção de saúde).

Tendência adaptativa podendo dar liberdade para relações positivas.

\section{- AVALIAÇÃO MULTIAXIAL - EIXO V - DSM-IV}

Escala de Avaliação Global do Funcionamento (AGF) - Pontuação: 58

Sintomas moderados. Humor depressivo com ataques de pânico ocasionais e fala circunstancial. 


\section{PACIENTE 4}

Idade: 56 anos sexo: masculino

HD: IAM SST (Infarto Agudo do Miocárdio com Supradesnivelamento de Seguimento ST)

Classe Funcional NYHA: CF III

- ANÁLISE E INTERPRETAÇÃO DO TRO:

Quadro 24. Avaliação das lâminas - paciente 4 do grupo C:

\begin{tabular}{|c|c|c|c|c|c|}
\hline & \multicolumn{3}{|c|}{ STID } & \multirow{2}{*}{$\begin{array}{c}\text { Fantasia } \\
\text { Inconsciente } \\
\text { Dominante }\end{array}$} & \multirow[b]{2}{*}{ Pontos } \\
\hline & $\begin{array}{c}\text { Desejos } \\
\text { Inconscientes }\end{array}$ & $\begin{array}{c}\text { Medos / } \\
\text { Ansiedades }\end{array}$ & $\begin{array}{c}\text { Mecanismos } \\
\text { de Defesa }\end{array}$ & & \\
\hline A1 & $\begin{array}{c}\text { Paralisar o } \\
\text { objeto ou self }\end{array}$ & Persecutoriedade & $\begin{array}{l}\text { Clivagem / } \\
\text { cisão }\end{array}$ & Fragmentação & 2 \\
\hline AG & $\begin{array}{l}\text { Proteger do } \\
\text { aniquilamento }\end{array}$ & $\begin{array}{l}\text { Aniquilamento, } \\
\text { angústia } \\
\text { depressiva }\end{array}$ & $\begin{array}{l}\text { Identificação } \\
\text { projetiva e } \\
\text { introjetiva }\end{array}$ & Morte & $2-3$ \\
\hline B3 & $\begin{array}{l}\text { Fusão com o } \\
\text { objeto amado }\end{array}$ & $\begin{array}{c}\text { Aniquilamento, } \\
\text { progredir }\end{array}$ & Escotomização & $\begin{array}{c}\text { Desaparecimento } \\
\text { do self }\end{array}$ & $1-2$ \\
\hline BG & $\begin{array}{c}\text { Separar } \\
\text { objeto bom e } \\
\text { mau }\end{array}$ & $\begin{array}{c}\text { Ansiedade } \\
\text { confusional, } \\
\text { ambivalência }\end{array}$ & Escotomização & Fragmentação & 2 \\
\hline $\mathrm{C} 2$ & $\begin{array}{c}\text { Paralisar o } \\
\text { objeto ou self }\end{array}$ & Confusão & Negação & Fragmentação & 2 \\
\hline $\mathrm{Br}$ & $\begin{array}{l}\text { Proteger do } \\
\text { aniquilamento }\end{array}$ & $\begin{array}{l}\text { Angústia } \\
\text { depressiva }\end{array}$ & $\begin{array}{l}\text { Introjeção do } \\
\text { bom objeto }\end{array}$ & Morte & $3-4$ \\
\hline & & & & & $\begin{array}{c}\mathrm{N}=12-15 \\
\text { Média }=2-2,5\end{array}$ \\
\hline
\end{tabular}

Aspectos manifestos: homem, conteúdo de realidade negado (A1); pessoas, casa, porta (AG); criança, idoso, casa (B3); pessoas, casa (BG); ser humano, conteúdo de realidade negado (C2); ser humano, rua (Branca). 
Análise: a situação imposta em A1 (solidão) gera ansiedade, “desespero”, projeta a figura de um homem que tenta seguir seu percurso, mas "está olhando para trás, sem fisionomia, triste”.

Ignora situação triangular imposta pela lâmina B3 devido à intensa ansiedade. Inclui uma parte regressiva no par (criança), indicando negação do estímulo apresentado na lâmina.

Angústia depressiva mobilizada em AG, com personagens que sentem o pesar por seus objetos perdidos. Apresenta aspectos destruídos do ego.

Ambivalência identificada e negação do personagem excluído (BG) devido angústia persecutória diante do estímulo, demonstrando dificuldade em lidar com seus pares.

Ignora personagem na cama em $\mathrm{C} 2$ e a transforma aquele que foi citado em um "ser humano sem rumo”, indicando como lida ou lidará com suas perdas (doença) e como agirá diante do sofrimento.

Cria uma situação que gratifica (Branca) com a narrativa de um "refúgio" importante neste momento. Considera que o lugar projetado traria sossego (e, com ele, a possibilidade de aceitar a condição física atual). Angústia depressiva presente.

Equilíbrio adaptativo não mantido e há predomínio de ansiedade, além de relações negativas.

\section{- AVALIAÇÃO MULTIAXIAL - EIXO V - DSM-IV}

Escala de Avaliação Global do Funcionamento (AGF) - Pontuação: 38

Algum prejuízo no teste de realidade e na comunicação, além de déficit nas áreas de julgamento, pensamento e humor. 


\section{PACIENTE 5}

Idade: 62 anos sexo: masculino

HD: ICC (Insuficiência Cardíaca Crônica)

Classe Funcional NYHA: CF II - III (atualmente)

\section{- ANÁLISE E INTERPRETAÇÃO DO TRO:}

Quadro 25. Avaliação das lâminas - paciente 5 do grupo C:

\begin{tabular}{|c|c|c|c|c|c|}
\hline & \multicolumn{3}{|c|}{ STID } & \multirow{2}{*}{$\begin{array}{c}\text { Fantasia } \\
\text { Inconsciente } \\
\text { Dominante }\end{array}$} & \multirow[b]{2}{*}{ Pontos } \\
\hline & $\begin{array}{c}\text { Desejos } \\
\text { Inconscientes }\end{array}$ & $\begin{array}{c}\text { Medos / } \\
\text { Ansiedades }\end{array}$ & $\begin{array}{c}\text { Mecanismos } \\
\text { de Defesa }\end{array}$ & & \\
\hline A1 & $\begin{array}{c}\text { Paralisar o } \\
\text { objeto ou self }\end{array}$ & $\begin{array}{l}\text { Angústia, } \\
\text { persecutoriedade, } \\
\text { solidão }\end{array}$ & $\begin{array}{l}\text { Clivagem / } \\
\text { cisão }\end{array}$ & Fragmentação & 2 \\
\hline AG & $\begin{array}{c}\text { Paralisar o } \\
\text { objeto ou self }\end{array}$ & $\begin{array}{c}\text { Ansiedade } \\
\text { persecutória, } \\
\text { aniquilamento }\end{array}$ & $\begin{array}{c}\text { Negação, } \\
\text { controle } \\
\text { onipotente } \\
\end{array}$ & $\begin{array}{c}\text { Morte, } \\
\text { desaparecimento } \\
\text { do self } \\
\end{array}$ & 2 \\
\hline B3 & $\begin{array}{l}\text { Fusão com o } \\
\text { objeto amado }\end{array}$ & Perseguição & $\begin{array}{c}\text { Negação / } \\
\text { escotomização }\end{array}$ & Fusão & $1-2$ \\
\hline BG & $\begin{array}{c}\text { Proteger do } \\
\text { aniquilamento }\end{array}$ & $\begin{array}{c}\text { Inveja, } \\
\text { aniquilamento, } \\
\text { morte, solidão }\end{array}$ & $\begin{array}{l}\text { Identificação } \\
\text { projetiva e } \\
\text { introjetiva }\end{array}$ & Dependência & 2 \\
\hline $\mathrm{C} 2$ & $\begin{array}{c}\text { Separar } \\
\text { objeto bom e } \\
\text { mau }\end{array}$ & Aniquilamento & $\begin{array}{c}\text { Negação / } \\
\text { escotomização }\end{array}$ & $\begin{array}{c}\text { Morte, } \\
\text { desaparecimento } \\
\text { do self }\end{array}$ & 2 \\
\hline $\mathrm{Br}$ & Dependência & $\begin{array}{l}\text { Angústia } \\
\text { confusional }\end{array}$ & $\begin{array}{l}\text { Negação, } \\
\text { clivagem }\end{array}$ & Fusão & $1-2$ \\
\hline & & & & & $\begin{array}{c}\mathrm{N}=10-12 \\
\text { Média }=1,5-2\end{array}$ \\
\hline
\end{tabular}

Aspectos manifestos: homem, pernas, braços, jardim (A1); conteúdo humano negado, pinguins, água, praia (AG); homem, mulher, túnica, rua (B3); pastores, pessoas, igreja (BG); conteúdo humano negado, igreja (C2); paciente, história (Branca). 
Análise: está diante de uma situação ameaçadora (A1), vendo-se sozinho na tentativa de solucionar um problema que "talvez não consiga". O homem não é inteiro, apresenta o personagem fragmentado.

Ignora o personagem que compões a situação triangular (B3). O homem fusiona-se à mulher e vestem uma "única túnica" enquanto buscam um caminho. Ansiedade elevada, atitude regressiva.

Desloca o drama humano para uma narrativa de pinguins que buscam água (AG). Elabora maniacamente o conteúdo que emerge devido ansiedade diante do estímulo.

Aceita a situação de exclusão espacial de um personagem (BG) e aparecem fantasias de continente estável (igreja) e de doença / cura. O grupo está unido e orando por uma pessoa doente (o grupo lhe traz segurança). Sentimento de inveja presente (do pastor, o que é sadio).

A morte é negada (C2) e deslocada para o conteúdo de realidade (ambiente triste). Ignora personagens que aparecem na lâmina e reforça a defesa afirmando que "não há ninguém ali". Demonstra certa possibilidade reparatória ao dizer que o ambiente (igreja) "é triste, mas está em reforma, será pintada”.

Elabora maniacamente como negação ao que foi mobilizado (Branca), supondo a não aceitação do sofrimento e, consequentemente, de tratamentos.

Não mantém o equilíbrio adaptativo. Predomínio de ansiedade com relações muito negativas.

\section{- AVALIAÇÃO MULTIAXIAL - EIXO V - DSM-IV}

Escala de Avaliação Global do Funcionamento (AGF) - Pontuação: 38

Algum prejuízo no teste de realidade ou na comunicação, bem como nas diversas áreas: pensamento, julgamento, relações familiares e humor. 


\section{PACIENTE 6}

Idade: 66 anos sexo: masculino

HD: ICC (Insuficiência Cardíaca Crônica)

Classe Funcional NYHA: CF III

- ANÁLISE E INTERPRETAÇÃO DO TRO:

Quadro 26. Avaliação das lâminas - paciente 6 do grupo C:

\begin{tabular}{|c|c|c|c|c|c|}
\hline & \multicolumn{3}{|c|}{ STID } & \multirow{2}{*}{$\begin{array}{c}\text { Fantasia } \\
\text { Inconsciente } \\
\text { Dominante }\end{array}$} & \multirow[b]{2}{*}{ Pontos } \\
\hline & $\begin{array}{c}\text { Desejos } \\
\text { Inconscientes }\end{array}$ & $\begin{array}{c}\text { Medos / } \\
\text { Ansiedades }\end{array}$ & $\begin{array}{l}\text { Mecanismos } \\
\text { de Defesa }\end{array}$ & & \\
\hline A1 & $\begin{array}{c}\text { Paralisar o } \\
\text { objeto ou self }\end{array}$ & Solidão & Paralisação & $\begin{array}{c}\text { Desaparecimento } \\
\text { do self }\end{array}$ & 2 \\
\hline$A G$ & Simbiose & Ansiedade & $\begin{array}{l}\text { Identificação } \\
\text { adesiva, } \\
\text { escotomização }\end{array}$ & $\begin{array}{c}\text { Desaparecimento } \\
\text { do self }\end{array}$ & $1-2$ \\
\hline B3 & $\begin{array}{c}\text { Separar } \\
\text { objeto bom e } \\
\text { mau }\end{array}$ & Solidão & $\begin{array}{c}\text { Idealização, } \\
\text { identificação } \\
\text { projetiva }\end{array}$ & Separação & 3 \\
\hline BG & $\begin{array}{c}\text { Paralisar o } \\
\text { objeto ou self }\end{array}$ & Ambivalência & Escotomização & $\begin{array}{c}\text { Desaparecimento } \\
\text { do self }\end{array}$ & $1-2$ \\
\hline $\mathrm{C} 2$ & $\begin{array}{c}\text { Paralisar o } \\
\text { objeto ou self }\end{array}$ & Persecutoriedade & $\begin{array}{l}\text { Controle } \\
\text { onipotente }\end{array}$ & $\begin{array}{c}\text { Desaparecimento } \\
\text { do self }\end{array}$ & 2 \\
\hline $\mathrm{Br}$ & $\begin{array}{c}\text { Proteger do } \\
\text { aniquilamento }\end{array}$ & Aniquilamento & $\begin{array}{l}\text { Introjeção do } \\
\text { bom objeto }\end{array}$ & $\begin{array}{c}\text { Perda e } \\
\text { elaboração do } \\
\text { luto }\end{array}$ & 4 \\
\hline & & & & & $\begin{array}{l}\mathrm{N}=13-15 \\
\text { Média }=2,5\end{array}$ \\
\hline
\end{tabular}

Aspectos manifestos: homem, sombra, árvore (A1); amigos, praia, fundo do mar (AG); casal, pessoa, quarto (B3); pessoas, igreja, culto (BG); jovem, pessoas, árvores, caverna, cabana, filme (C2); nenhum aspecto manifesto (Branca). 
Análise: visualiza o personagem "preocupado e sozinho" (A1) como "apenas sombra", tentando solucionar um problema. $\mathrm{O}$ homem próximo à árvore pensa em fazer algo, mas permanece imóvel.

Admite o terceiro na relação triangular imposta pela lâmina B3. O personagem excluído do casal apenas observa. Todos “estão bem” neste momento, sugerindo idealização desta situação.

Elaboração maníaca presente em AG com a projeção de pessoas felizes / alegres na praia. Utiliza como defesa a identificação adesiva como negação onipotente e apresenta intensa ansiedade uma vez que a lâmina mobiliza questões de perda objetal.

Ambivalência em BG quando se refere a um grupo de pessoas tristes e intitulando a história como "realizações". Ignora o personagem excluído devido à ansiedade que foi mobilizada.

Reconhece personagem na cama $(\mathrm{C} 2)$, porém, controla onipotentemente devido ao conteúdo mobilizado (perdas - doença - condição clínica) e atribuindo a origem da narrativa a um filme antigo.

Possibilidade de recuperação diante da perda (objetal) e elabora depressivamente aceitando o seu sofrimento e projetando melhora referente à condição clínica atual.

Tende a atingir o equilíbrio adaptativo, porém, no momento, estabelece relações negativas.

\section{- AVALIAÇÃO MULTIAXIAL - EIXO V - DSM-IV}

Escala de Avaliação Global do Funcionamento (AGF) - Pontuação: 55

Apresenta determinados sintomas moderados e alguma dificuldade no funcionamento social. 


\section{PACIENTE 7}

Idade: 60 anos sexo: feminino

HD: ICC (Insuficiência Cardíaca Crônica) + Derrame pleural

Classe Funcional NYHA: CF III

- ANÁLISE E INTERPRETAÇÃO DO TRO:

Quadro 27. Avaliação das lâminas - paciente 7 do grupo C:

\begin{tabular}{|c|c|c|c|c|c|}
\hline & \multicolumn{3}{|c|}{ STID } & \multirow{2}{*}{$\begin{array}{c}\text { Fantasia } \\
\text { Inconsciente } \\
\text { Dominante }\end{array}$} & \multirow[b]{2}{*}{ Pontos } \\
\hline & $\begin{array}{c}\text { Desejos } \\
\text { Inconscientes }\end{array}$ & $\begin{array}{c}\text { Medos / } \\
\text { Ansiedades }\end{array}$ & $\begin{array}{l}\text { Mecanismos } \\
\text { de Defesa }\end{array}$ & & \\
\hline A1 & Dependência & Ambivalência & $\begin{array}{l}\text { Clivagem, } \\
\text { idealização }\end{array}$ & $\begin{array}{l}\text { Aniquilamento, } \\
\text { morte }\end{array}$ & $1-2$ \\
\hline $\mathrm{AG}$ & $\begin{array}{c}\text { Separar } \\
\text { objeto bom e } \\
\text { mau } \\
\end{array}$ & $\begin{array}{l}\text { Angústia } \\
\text { depressiva }\end{array}$ & $\begin{array}{c}\text { Identificação } \\
\text { projetiva e } \\
\text { introjetiva }\end{array}$ & Separação, morte & $3-4$ \\
\hline B3 & $\begin{array}{l}\text { Fusão com o } \\
\text { objeto amado }\end{array}$ & $\begin{array}{c}\text { Angústia/ } \\
\text { persecutoriedade }\end{array}$ & Escotomização & Fusão & $1-2$ \\
\hline $\mathrm{BG}$ & $\begin{array}{l}\text { Ser vista, } \\
\text { notada }\end{array}$ & Inveja, solidão & $\begin{array}{c}\text { Identificação } \\
\text { projetiva }\end{array}$ & $\begin{array}{c}\text { Morte, } \\
\text { desaparecimento }\end{array}$ & 3 \\
\hline $\mathrm{C} 2$ & $\begin{array}{c}\text { Ser notada, } \\
\text { separar } \\
\text { objetos }\end{array}$ & Solidão & $\begin{array}{c}\text { Identificação } \\
\text { projetiva }\end{array}$ & Separação, morte & 3 \\
\hline $\mathrm{Br}$ & $\begin{array}{c}\text { Separar } \\
\text { objeto bom e } \\
\text { mau }\end{array}$ & Solidão & $\begin{array}{c}\text { Identificação } \\
\text { projetiva }\end{array}$ & Morte & $2-3$ \\
\hline & & & & & $\begin{array}{l}\mathrm{N}=13-18 \\
\text { Média }=2,5\end{array}$ \\
\hline
\end{tabular}

Aspectos manifestos: homem, nuvens (A1); pessoas, campo (AG); casal, homem, mulher, igreja (B3); família, pessoa, casa, porta (BG); pessoas, casa (C2); pessoas, família (Branca). 
Análise: vislumbra um homem sozinho e nas nuvens (A1), preocupado, demonstrando certa ambivalência uma vez que, nas nuvens, estaria morto. No entanto, este homem ainda “pensa na vida”.

Nega o terceiro que compõe a situação triangular em B3. Narra a história de um casal apaixonado em uma igreja e se defende do estímulo apresentado.

Sente depressivamente o conteúdo da lâmina AG e C2. São mobilizados afetos relacionados à perda objetal (tristeza).

Exclui personagem do grupo (BG). Projeta uma casa com "família feliz" e um personagem isolado, "triste e sozinho", ignorado pelos demais. Sentimento de que deverá enfrentar as dificuldades, sozinha (inveja a alegria do grupo).

Admite os personagens da lâmina C2 que, apesar de distantes, comunicam-se. A pessoa acamada foi abandonada e a que está em pé não ajuda, apenas observa e conversa (demonstrando como sente a vivência da perda, em sua solidão).

Manifesta ter poucos recursos para lidar com a sua condição clínica e, diante da perda, encara a solidão com precariedade, tornando o enfrentamento custoso.

Equilíbrio não mantido. Predomínio de ansiedade com relações negativas. Poderá atingir a adaptação.

\section{- AVALIAÇÃO MULTIAXIAL - EIXO V - DSM-IV}

Escala de Avaliação Global do Funcionamento (AGF) - Pontuação: 51

Apresenta sintomas moderados como afeto embotado e fala circunstancial. Humor depressivo. 


\section{PACIENTE 8}

Idade: 65 anos sexo: masculino

HD: ICC (Insuficiência Cardíaca Crônica)

Classe Funcional NYHA: CF III - IV (atualmente)

- ANÁLISE E INTERPRETAÇÃO DO TRO:

Quadro 28. Avaliação das lâminas - paciente 8 do grupo C:

\begin{tabular}{|c|c|c|c|c|c|}
\hline & \multicolumn{3}{|c|}{ STID } & \multirow{2}{*}{$\begin{array}{c}\text { Fantasia } \\
\text { Inconsciente } \\
\text { Dominante }\end{array}$} & \multirow[b]{2}{*}{ Pontos } \\
\hline & $\begin{array}{c}\text { Desejos } \\
\text { Inconscientes }\end{array}$ & $\begin{array}{c}\text { Medos / } \\
\text { Ansiedades }\end{array}$ & $\begin{array}{c}\text { Mecanismos } \\
\text { de Defesa }\end{array}$ & & \\
\hline A1 & $\begin{array}{l}\text { Proteger do } \\
\text { aniquilamento }\end{array}$ & $\begin{array}{l}\text { Aniquilamento, } \\
\text { ambivalência }\end{array}$ & $\begin{array}{c}\text { Controle } \\
\text { onipotente, } \\
\text { idealização }\end{array}$ & $\begin{array}{l}\text { Destruição do } \\
\text { objeto }\end{array}$ & 2 \\
\hline AG & $\begin{array}{c}\text { Paralisar o } \\
\text { objeto ou self }\end{array}$ & $\begin{array}{l}\text { Ansiedade } \\
\text { confusional }\end{array}$ & $\begin{array}{l}\text { Imobilização, } \\
\text { paralisação, } \\
\text { escotomização }\end{array}$ & Paralisação & $1-2$ \\
\hline B3 & $\begin{array}{l}\text { Fusão com o } \\
\text { objeto amado }\end{array}$ & $\begin{array}{c}\text { Ausência } \\
\text { sentido, confusão }\end{array}$ & $\begin{array}{l}\text { Idealização, } \\
\text { escotomização }\end{array}$ & Fusão & $1-2$ \\
\hline BG & Simbiose & Aniquilamento & $\begin{array}{c}\text { Idealização, } \\
\text { identificação } \\
\text { adesiva }\end{array}$ & Fusão & 2 \\
\hline $\mathrm{C} 2$ & $\begin{array}{l}\text { Fusão com o } \\
\text { objeto amado }\end{array}$ & Solidão & $\begin{array}{c}\text { Controle de } \\
\text { objetos, } \\
\text { escotomização }\end{array}$ & Paralisação & 2 \\
\hline $\mathrm{Br}$ & $\begin{array}{c}\text { Paralisar o } \\
\text { objeto ou self }\end{array}$ & Ambivalência & $\begin{array}{c}\text { Controle de } \\
\text { objetos }\end{array}$ & Paralisação & 2 \\
\hline & & & & & $\begin{array}{c}\mathrm{N}=10-12 \\
\text { Média }=1,5-2\end{array}$ \\
\hline
\end{tabular}

Aspectos manifestos: pessoa, homem, vulto, jardim, escuridão (A1); conteúdo humano negado, bananas, campo, jardim (AG); casal, homem, mulher, porta, igreja (B3); homem, matagal, galinheiro (BG); folha, tela de cinema, lâmpada, campo magnético (Branca). 
Análise: defende-se maniacamente do estímulo da primeira lâmina do teste (A1). Inicia com a narrativa de um homem, "apenas vulto”, em um jardim escuro. Ao final, afirma que este homem está alegre, defendendo-se do conteúdo mobilizado.

O terceiro excluído é negado (B3) e a imagem central transformada em noivos que estão na igreja para o casamento. Idealização presente como defesa maníaca.

São mobilizadas defesas maníacas de estrutura esquizóide (AG), com a desumanização da figura / estímulo apresentado e congelamento dos afetos, concebendo que está é “uma figura de bananas”.

Admite o personagem isolado do grupo (BG), mas pertencente a este, "participam de um culto, estão rezando". Considera-se incapaz de tolerar o percurso de sofrimento sozinho e idealiza o contato / vínculo com seus pares.

Ignora personagem acamado (C2) e a morte aparece negada. Narra uma história de solidão vinculada a uma situação de crise.

Encara a lâmina Branca como aquela que possibilita a criação de algo novo. No entanto, defende-se maniacamente com a descrição de uma sucessão de objetos inanimados como "folha, tela de cinema ou lâmpada".

Equilíbrio adaptativo não mantido. Predomínio de ansiedade e de relações negativas ou muito negativas.

\section{- AVALIAÇÃO MULTIAXIAL - EIXO V - DSM-IV}

Escala de Avaliação Global do Funcionamento (AGF) - Pontuação: 33

Prejuízos no teste de realidade e na comunicação (fala circunstancial). Apresenta sintomas moderados como oscilações de humor. 


\section{PACIENTE 9}

Idade: 73 anos sexo: feminino

HD: IC (Insuficiência Cardíaca) - Acidente Vascular Cerebral Isquêmico (AVCi)

Classe Funcional NYHA: CF III

- ANÁLISE E INTERPRETAÇÃO DO TRO:

Quadro 29. Avaliação das lâminas - paciente 9 do grupo C:

\begin{tabular}{|c|c|c|c|c|c|}
\hline & \multicolumn{3}{|c|}{ STID } & \multirow{2}{*}{$\begin{array}{c}\text { Fantasia } \\
\text { Inconsciente } \\
\text { Dominante }\end{array}$} & \multirow[b]{2}{*}{ Pontos } \\
\hline & $\begin{array}{c}\text { Desejos } \\
\text { Inconscientes }\end{array}$ & $\begin{array}{c}\text { Medos / } \\
\text { Ansiedades }\end{array}$ & $\begin{array}{c}\text { Mecanismos } \\
\text { de Defesa }\end{array}$ & & \\
\hline A1 & $\begin{array}{c}\text { Paralisar o } \\
\text { objeto ou self }\end{array}$ & Solidão & $\begin{array}{c}\text { Identificação } \\
\text { projetiva }\end{array}$ & Paralisação & $2-3$ \\
\hline AG & $\begin{array}{c}\text { Paralisar o } \\
\text { objeto ou self }\end{array}$ & $\begin{array}{l}\text { Desesperança, } \\
\text { solidão }\end{array}$ & $\begin{array}{c}\text { Identificação } \\
\text { projetiva }\end{array}$ & $\begin{array}{l}\text { Destruição do } \\
\text { objeto }\end{array}$ & 2 \\
\hline B3 & Dependência & $\begin{array}{c}\text { Inveja, } \\
\text { autodesvalorização }\end{array}$ & $\begin{array}{c}\text { Identificação } \\
\text { projetiva }\end{array}$ & Separação & 3 \\
\hline BG & $\begin{array}{c}\text { Separar } \\
\text { objeto bom e } \\
\text { mau } \\
\end{array}$ & $\begin{array}{l}\text { Insegurança, } \\
\text { solidão }\end{array}$ & $\begin{array}{c}\text { Identificação } \\
\text { projetiva }\end{array}$ & Separação & 3 \\
\hline $\mathrm{C} 2$ & $\begin{array}{c}\text { Paralisar o } \\
\text { objeto ou self }\end{array}$ & $\begin{array}{l}\text { Ansiedade } \\
\text { confusional }\end{array}$ & Negação & Paralisação & 2 \\
\hline $\mathrm{Br}$ & $\begin{array}{l}\text { Destruir o } \\
\text { objeto }\end{array}$ & Persecutoriedade & $\begin{array}{l}\text { Negação, } \\
\text { paralisação }\end{array}$ & $\begin{array}{l}\text { Destruição do } \\
\text { objeto }\end{array}$ & $1-2$ \\
\hline & & & & & $\begin{array}{c}\mathrm{N}=13-15 \\
\text { Média }=2-2,5\end{array}$ \\
\hline
\end{tabular}

Aspectos manifestos: pessoa, homem, imagem, deserto (A1); pessoas, espaço (AG); casal, pessoa, rua (B3); pessoas, casa abandonada (BG); pessoas, espaço (C2); nenhum aspecto manifesto (Branca). 
Análise: identifica-se projetivamente com a sua solidão na primeira lâmina do teste (A1), narrando a história de um personagem “cheio de problemas” em uma situação regressiva e ameaçadora. A exploração transferencial fica prejudicada, já que não inclui um segundo personagem.

Admite a situação triangular (B3) e projeta um personagem excluído da relação do casal que "está triste, no escuro". Sentimento de inveja e autodesvalorização, pois precisa de ajuda. Aparecem aspectos da própria depressão, como tristeza (AG). Parte do ego sofre e não apresenta condições para reparar a destruição.

Narra uma situação de exclusão, não apenas espacial, com fantasias de continente estável (BG). Intenso sentimento de solidão diante do grupo. Insere um personagem isolado, diferente dos demais porque está "triste e precisando de ajuda".

Apesar de negar o personagem na cama (C2), sente depressivamente o conteúdo da lâmina e narra uma história de "pessoas perdidas que precisam de ajuda, e que não pensam”, paralisando o objeto.

A situação de separação (Branca) intensifica a ansiedade e são mobilizados conteúdos que demonstram sua dificuldade em lidar com a condição clínica, utilizando a elaboração maníaca como negação deste momento.

Equilíbrio adaptativo não mantido com predomínio de ansiedade. Poderá atingir a adaptação.

\section{- AVALIAÇÃO MULTIAXIAL - EIXO V - DSM-IV}

Escala de Avaliação Global do Funcionamento (AGF) - Pontuação: 40

Algum prejuízo no teste de realidade e na comunicação. Apresenta sintomas como depressão e crises de pânico. 


\section{PACIENTE 10}

Idade: 75 anos sexo: feminino

HD: ICC (Insuficiência Cardíaca Crônica) descompensada

Classe Funcional NYHA: CF III - IV (atualmente)

- ANÁLISE E INTERPRETAÇÃO DO TRO:

Quadro 30. Avaliação das lâminas - paciente 10 do grupo C:

\begin{tabular}{|c|c|c|c|c|c|}
\hline & \multicolumn{3}{|c|}{ STID } & \multirow{2}{*}{$\begin{array}{c}\text { Fantasia } \\
\text { Inconsciente } \\
\text { Dominante }\end{array}$} & \multirow[b]{2}{*}{ Pontos } \\
\hline & $\begin{array}{c}\text { Desejos } \\
\text { Inconscientes }\end{array}$ & $\begin{array}{c}\text { Medos / } \\
\text { Ansiedades }\end{array}$ & $\begin{array}{l}\text { Mecanismos } \\
\text { de Defesa }\end{array}$ & & \\
\hline A1 & $\begin{array}{c}\text { Paralisar o } \\
\text { objeto ou self }\end{array}$ & Solidão & $\begin{array}{l}\text { Identificação } \\
\text { projetiva }\end{array}$ & Paralisação & 3 \\
\hline AG & $\begin{array}{l}\text { Fusão com o } \\
\text { objeto amado }\end{array}$ & $\begin{array}{c}\text { Ausência de } \\
\text { sentido no real / } \\
\text { clivagem }\end{array}$ & Clivagem & Fragmentação & $1-2$ \\
\hline B3 & $\begin{array}{l}\text { Fusão com o } \\
\text { objeto amado }\end{array}$ & $\begin{array}{l}\text { Ambivalência, } \\
\text { ansiedade } \\
\text { confusional }\end{array}$ & $\begin{array}{c}\text { Idealização, } \\
\text { controle } \\
\text { onipotente }\end{array}$ & Fusão & $1-2$ \\
\hline BG & $\begin{array}{l}\text { Fusão com o } \\
\text { objeto amado }\end{array}$ & $\begin{array}{l}\text { Aniquilamento, } \\
\text { persecutoriedade }\end{array}$ & Escotomização & $\begin{array}{l}\text { Fusão, } \\
\text { aniquilamento }\end{array}$ & $1-2$ \\
\hline $\mathrm{C} 2$ & $\begin{array}{c}\text { Paralisar o } \\
\text { objeto ou self }\end{array}$ & Persecutoriedade & Escotomização & Paralisação & 2 \\
\hline $\mathrm{Br}$ & Dependência & Aniquilamento & Negação & $\begin{array}{l}\text { Destruição do } \\
\text { objeto }\end{array}$ & $1-2$ \\
\hline & & & & & $\begin{array}{c}\mathrm{N}=9-13 \\
\text { Média }=1,5-2\end{array}$ \\
\hline
\end{tabular}

Aspectos manifestos: homem, planta, quintal, terra (A1); pessoas, cataratas, água (AG); padres, missa (B3); pessoas, igreja (BG); homem, folhas, roupa, jardim (C2); branco, limpeza (Branca). 
Análise: é colocado diante de sua solidão e paralisa o objeto que fica "distante, de braços cruzados". O personagem "não enfrenta, apenas observa” (A1).

O conteúdo que emerge diante da situação triangular é onipotentemente controlado (B3). Os três personagens são vislumbrados como padres que rezam uma missa: apesar de "diferentes", apresentam-se em condição de igualdade.

Elabora maniacamente o conteúdo que emerge em AG: distancia-se da realidade e não assume a depressão, que seria imposta como condição para lidar com perdas (luto).

Ignora o personagem excluído do grupo (BG) devido intensa ansiedade persecutória diante da lâmina. Confunde-se com o grupo, fica misturada.

Nega o personagem acamado (C2) e paralisa o objeto que "não faz nada, fica parado". Intensa ansiedade mobilizada: nega a realidade da morte e apresenta o sentimento de persecutoriedade.

A ansiedade mobilizada diante do conteúdo da última lâmina a faz se utilizar de elaboração maníaca como negação, defendendo-se neste momento de separação.

Não mantém o equilíbrio adaptativo. Há predomínio de ansiedade e relações muito negativas.

\section{- AVALIAÇÃO MULTIAXIAL - EIXO V - DSM-IV}

Escala de Avaliação Global do Funcionamento (AGF) - Pontuação: 35

Algum prejuízo no teste de realidade, lapsos de memória devido ao quadro neurológico, além de comprometimento nos aspectos relacionados à capacidade de julgamento. 


\section{PACIENTE 11}

Idade: 52 anos sexo: feminino

HD: IC (Insuficiência Cardíaca) descompensada e ITU (Infecção do Trato Uterino)

Classe Funcional NYHA: CF III

- ANÁLISE E INTERPRETAÇÃO DO TRO:

Quadro 31. Avaliação das lâminas - paciente 11 do grupo C:

\begin{tabular}{|c|c|c|c|c|c|}
\hline & \multicolumn{3}{|c|}{ STID } & \multirow{2}{*}{$\begin{array}{c}\text { Fantasia } \\
\text { Inconsciente } \\
\text { Dominante }\end{array}$} & \multirow[b]{2}{*}{ Pontos } \\
\hline & $\begin{array}{c}\text { Desejos } \\
\text { Inconscientes }\end{array}$ & $\begin{array}{c}\text { Medos / } \\
\text { Ansiedades }\end{array}$ & $\begin{array}{l}\text { Mecanismos } \\
\text { de Defesa }\end{array}$ & & \\
\hline A1 & $\begin{array}{c}\text { Paralisar o } \\
\text { objeto ou self }\end{array}$ & $\begin{array}{l}\text { Persecutoriedade, } \\
\text { ambivalência }\end{array}$ & $\begin{array}{c}\text { Identificação } \\
\text { projetiva }\end{array}$ & $\begin{array}{l}\text { Paralisar o } \\
\text { objeto }\end{array}$ & 2 \\
\hline $\mathrm{AG}$ & $\begin{array}{c}\text { Paralisar o } \\
\text { objeto ou self }\end{array}$ & $\begin{array}{l}\text { Ansiedade } \\
\text { confusional }\end{array}$ & Escotomização & Paralisação & $1-2$ \\
\hline B3 & $\begin{array}{l}\text { Fusão com o } \\
\text { objeto amado }\end{array}$ & $\begin{array}{l}\text { Ansiedade } \\
\text { confusional }\end{array}$ & Escotomização & Fusão & $1-2$ \\
\hline BG & $\begin{array}{c}\text { Separar } \\
\text { objeto bom e } \\
\text { mau }\end{array}$ & $\begin{array}{l}\text { Aniquilamento, } \\
\text { persecutoriedade }\end{array}$ & $\begin{array}{c}\text { Controle } \\
\text { onipotente }\end{array}$ & Separação & 3 \\
\hline $\mathrm{C} 2$ & $\begin{array}{c}\text { Paralisar o } \\
\text { objeto ou self }\end{array}$ & $\begin{array}{l}\text { Ansiedade } \\
\text { confusional }\end{array}$ & Negação & Paralisação & 2 \\
\hline $\mathrm{Br}$ & $\begin{array}{c}\text { Paralisar o } \\
\text { objeto ou self }\end{array}$ & $\begin{array}{c}\text { Medo do } \\
\text { aniquilamento }\end{array}$ & Negação & Paralisação & $1-2$ \\
\hline & & & & & $\begin{array}{l}\mathrm{N}=10-13 \\
\text { Média }=2\end{array}$ \\
\hline
\end{tabular}

Aspectos manifestos: homem, floresta (A1); pessoas, família, acampamento (AG); pessoas, crianças, casal, degrau, porta (B3); crianças, pessoa, sala, porta (BG); pessoa, viela (C2); nenhum aspecto manifesto (Branca). 
Análise: demonstra insegurança (ambivalência) e traz aspectos de sua solidão diante do estímulo (A1). Enfrenta o momento "apenas olhando, observando": narra a história de um personagem que tentou começar a pensar, mas desistiu, ficou “sem fazer nada".

Nega a situação triangular (B3) e se coloca em atitude regressiva diante do conteúdo da lâmina (dissocia-se e inclui a parte regressiva no par de crianças).

A realidade da morte é negada e elabora maniacamente o conteúdo mobilizado (AG), com certa ansiedade confusional na descrição do cenário e dos personagens, que estão “reunidos e felizes".

Admite o personagem excluído do grupo (BG) e o coloca como protetor dos que estão unidos (crianças), atribuindo ao excluído um papel de líder (aquele que controla) e atenuando a persecutoriedade que emergiu.

Não menciona o personagem na cama (C2) negando a realidade da morte, atribui características de "tristeza" ao personagem citado (que permanece imóvel), deslocando a angústia sentida frente ao estímulo da lâmina.

Defende-se maniacamente diante da última lâmina (Branca) e nega tudo o que foi mobilizado nesta situação de separação (encerramento) e na ausência de estímulo.

Equilíbrio adaptativo não mantido. Predomínio de relações negativas e intensa ansiedade.

\section{- AVALIAÇÃO MULTIAXIAL - EIXO V - DSM-IV}

Escala de Avaliação Global do Funcionamento (AGF) - Pontuação: 45

Prejuízos na comunicação e na capacidade de julgamento. Apresenta alguns sintomas como atitude controladora e desafiadora. 


\section{PACIENTE 12}

Idade: 49 anos sexo: masculino

HD: ICC (Insuficiência Cardíaca Crônica) - IC Aguda

Classe Funcional NYHA: CF III

- ANÁLISE E INTERPRETAÇÃO DO TRO:

Quadro 32. Avaliação das lâminas - paciente 12 do grupo C:

\begin{tabular}{|c|c|c|c|c|c|}
\hline & \multicolumn{3}{|c|}{ STID } & \multirow{2}{*}{$\begin{array}{c}\text { Fantasia } \\
\text { Inconsciente } \\
\text { Dominante }\end{array}$} & \multirow[b]{2}{*}{ Pontos } \\
\hline & $\begin{array}{c}\text { Desejos } \\
\text { Inconscientes }\end{array}$ & $\begin{array}{c}\text { Medos / } \\
\text { Ansiedades }\end{array}$ & $\begin{array}{c}\text { Mecanismos } \\
\text { de Defesa }\end{array}$ & & \\
\hline A1 & $\begin{array}{c}\text { Paralisar o } \\
\text { objeto ou self }\end{array}$ & Persecutoriedade & $\begin{array}{c}\text { Identificação } \\
\text { projetiva }\end{array}$ & Paralisação & $2-3$ \\
\hline AG & $\begin{array}{c}\text { Paralisar o } \\
\text { objeto ou self }\end{array}$ & Persecutoriedade & $\begin{array}{l}\text { Clivagem, } \\
\text { escotomização }\end{array}$ & Paralisação & $1-2$ \\
\hline B3 & $\begin{array}{c}\text { Simbiose, } \\
\text { dependência }\end{array}$ & Inveja & $\begin{array}{l}\text { Fragmentação, } \\
\text { escotomização }\end{array}$ & $\begin{array}{l}\text { Destruição do } \\
\text { objeto }\end{array}$ & $1-2$ \\
\hline BG & $\begin{array}{c}\text { Separar } \\
\text { objeto bom e } \\
\text { mau }\end{array}$ & Aniquilamento & $\begin{array}{l}\text { Introjeção do } \\
\text { bom objeto }\end{array}$ & Separação & $3-4$ \\
\hline $\mathrm{C} 2$ & $\begin{array}{c}\text { Paralisar o } \\
\text { objeto ou self }\end{array}$ & $\begin{array}{c}\text { Solidão, } \\
\text { aniquilamento }\end{array}$ & $\begin{array}{c}\text { Cisão / } \\
\text { clivagem, } \\
\text { negação }\end{array}$ & Morte & 2 \\
\hline $\mathrm{Br}$ & $\begin{array}{l}\text { Separar o } \\
\text { objeto }\end{array}$ & $\begin{array}{l}\text { Angústia } \\
\text { depressiva }\end{array}$ & Reparação & $\begin{array}{c}\text { Perda e } \\
\text { elaboração do } \\
\text { luto } \\
\end{array}$ & 6 \\
\hline & & & & & $\begin{array}{c}\mathrm{N}=15-18 \\
\text { Média }=2,5-3\end{array}$ \\
\hline
\end{tabular}

Aspectos manifestos: homem, pessoa, deserto, digital (A1); conteúdo humano negado, leão marinho, praia, animais, foca (AG); casal, pessoas, casa, igreja (B3); irmãos, pessoas, igreja (BG); senhora, pessoa, homem, mulher, leito, casa, quarto, cama (C2); paciente, pessoas, casa, caneta, carrinho, construção, obra, igreja (Branca). 
Análise: a situação de teste é temida. Demonstra persecutoriedade inicialmente e se identifica com o personagem (A1): sente-se sozinho, desamparado, com dificuldade para enfrentar o momento e "não vai a lugar nenhum".

A situação triangular é negada (B3) e cede lugar a um casal que "poderá ser enforcado" na cena. Demonstra inveja e fantasias de destruição do objeto.

Não capta o clima depressivo sugerido (AG) e desloca o drama humano para uma narrativa de “animais na beira da praia”, como elaboração maníaca e mecanismo de negação frente ao conteúdo mobilizado.

Cita o personagem excluído em BG e não lhe atribui papel de líder ou daquele que é ignorado pelo grupo: todos têm um objetivo comum, estão focados em uma tarefa. Demonstra, assim, capacidade de reintegração e sentimento de continência diante de seus pares.

Apesar de negar o personagem acamado (C2), desloca a depressão sentida para a narrativa de "uma senhora que vai deitar e ficará sossegada". Admite a realidade da morte, porém, com dificuldade para suportar algum aspecto: a relação do par, estimulado pela cena, fica cindida.

Possibilidade de elaboração depressiva (Branca) que pressupõe a aceitação do sofrimento e, consequentemente, de ajuda. É criada uma história que gratifica e que permite a reparação dos objetos destruídos.

Tendência adaptativa e condições para atingir elaboração depressiva.

\section{- AVALIAÇÃO MULTIAXIAL - EIXO V - DSM-IV}

Escala de Avaliação Global do Funcionamento (AGF) - Pontuação: 51

Sintomas moderados como embotamento afetivo e oscilações de humor. 


\section{PACIENTE 13}

Idade: 71 anos sexo: masculino

HD: ICC (Insuficiencia Cardiaca Cronica) descompensada + BCP (broncopneumonia) + derrame pleural

Classe Funcional NYHA: CF III

- ANÁLISE E INTERPRETAÇÃO DO TRO:

Quadro 33. Avaliação das lâminas - paciente 13 do grupo C:

\begin{tabular}{|c|c|c|c|c|c|}
\hline & \multicolumn{3}{|c|}{ STID } & \multirow{2}{*}{$\begin{array}{c}\text { Fantasia } \\
\text { Inconsciente } \\
\text { Dominante }\end{array}$} & \multirow[b]{2}{*}{ Pontos } \\
\hline & $\begin{array}{c}\text { Desejos } \\
\text { Inconscientes }\end{array}$ & $\begin{array}{c}\text { Medos / } \\
\text { Ansiedades }\end{array}$ & $\begin{array}{c}\text { Mecanismos } \\
\text { de Defesa }\end{array}$ & & \\
\hline A1 & $\begin{array}{l}\text { Fusão com o } \\
\text { objeto amado }\end{array}$ & Aniquilamento & Paralisação & $\begin{array}{c}\text { Desaparecimento } \\
\text { do self }\end{array}$ & $2-3$ \\
\hline AG & $\begin{array}{c}\text { Paralisar o } \\
\text { objeto ou self }\end{array}$ & $\begin{array}{l}\text { Ansiedade } \\
\text { confusional }\end{array}$ & $\begin{array}{l}\text { Fragmentação, } \\
\text { escotomização }\end{array}$ & Fragmentação & $1-2$ \\
\hline B3 & $\begin{array}{l}\text { Fusão com o } \\
\text { objeto amado }\end{array}$ & $\begin{array}{l}\text { Ansiedade } \\
\text { confusional }\end{array}$ & $\begin{array}{c}\text { Identificação } \\
\text { adesiva, } \\
\text { escotomização }\end{array}$ & Fusão & $1-2$ \\
\hline BG & $\begin{array}{c}\text { Separar } \\
\text { objeto bom e } \\
\text { mau }\end{array}$ & Aniquilamento & $\begin{array}{l}\text { Introjeção do } \\
\text { bom objeto }\end{array}$ & Separação & $3-4$ \\
\hline $\mathrm{C} 2$ & $\begin{array}{c}\text { Paralisar o } \\
\text { objeto ou self }\end{array}$ & Aniquilamento & $\begin{array}{c}\text { Cisão / } \\
\text { clivagem, } \\
\text { negação }\end{array}$ & Morte & 2 \\
\hline $\mathrm{Br}$ & $\begin{array}{c}\text { Paralisar o } \\
\text { objeto ou self }\end{array}$ & Aniquilamento & Negação & Dependência & 2 \\
\hline & & & & & $\begin{array}{c}\mathrm{N}=11-15 \\
\text { Média }=2-2,5\end{array}$ \\
\hline
\end{tabular}

Aspectos manifestos: homem, fumaça, incêndio, sombra, fogo (A1); pessoas, bananas, fumaça, frutas (AG); casal, manta, corpo, sala, porta (B3); crianças, rapaz, pessoas, muro, 
portas, janela, calçada, reunião, obra, construção (BG); operário, homem, quarto, cama, quadro (C2); tapete branco (Branca).

Análise: o personagem da primeira lâmina (A1) é projetado como um ser imóvel e que sucumbe ao sofrimento: solitário, fusiona-se com a fumaça e desaparece no fogo.

Ignora o terceiro excluído que pertence à relação triangular (B3) e projeta o encontro de um casal que está "coberto por uma manta". Apresenta aspectos de ansiedade confusional e desejo de se fusionar com o objeto.

O conflito apresentado (AG) é negado: elabora maniacamente os aspectos mobilizados demonstrando dificuldade em lidar com perdas (luto).

O personagem excluído é citado e não atribui a este ou ao grupo características de superioridade. O "rapaz" é acolhido e participa de uma "reunião", demonstrando sua capacidade de reintegração ao grupo.

A relação do par fica cindida $(\mathrm{C} 2)$ e é narrada a história de um único personagem. É capaz de admitir alguns aspectos do estímulo para tolerar a realidade da morte.

Elaboração maníaca diante da última lâmina (Branca), indicando o estabelecimento de uma relação transferencial de dependência e negando o que foi mobilizado nesta situação de separação.

Possibilidade de atingir a adaptação. No momento, não mantém o equilíbrio adaptativo e há predomínio de ansiedade.

\section{- AVALIAÇÃO MULTIAXIAL - EIXO V - DSM-IV}

Escala de Avaliação Global do Funcionamento (AGF) - Pontuação: 59

Apresenta alguns sintomas moderados (oscilações de humor) e é capaz de manter relacionamentos interpessoais significativos. 


\section{GRUPO D}

\section{PACIENTE 1}

Idade: 44 anos sexo: feminino

HD: ICC (Insuficiência Cardíaca) - CCC (Cardiopatia Chagásica Crônica)

Classe Funcional NYHA: CF IV

- ANÁLISE E INTERPRETAÇÃO DO TRO:

Quadro 34. Avaliação das lâminas - paciente 1 do grupo D:

\begin{tabular}{|c|c|c|c|c|c|}
\hline & \multicolumn{3}{|c|}{ STID } & \multirow{2}{*}{$\begin{array}{c}\text { Fantasia } \\
\text { Inconsciente } \\
\text { Dominante }\end{array}$} & \multirow[b]{2}{*}{ Pontos } \\
\hline & $\begin{array}{c}\text { Desejos } \\
\text { Inconscientes }\end{array}$ & $\begin{array}{c}\text { Medos / } \\
\text { Ansiedades }\end{array}$ & $\begin{array}{c}\text { Mecanismos } \\
\text { de Defesa }\end{array}$ & & \\
\hline A1 & $\begin{array}{c}\text { Simbiose, } \\
\text { dependência }\end{array}$ & $\begin{array}{l}\text { Ansiedade } \\
\text { confusional }\end{array}$ & $\begin{array}{c}\text { Controle de } \\
\text { objetos }\end{array}$ & Fusão, simbiose & $1-2$ \\
\hline $\mathrm{AG}$ & $\begin{array}{c}\text { Paralisar o } \\
\text { objeto ou self }\end{array}$ & $\begin{array}{c}\text { Angústia, } \\
\text { persecutoriedade }\end{array}$ & Escotomização & Paralisação & $1-2$ \\
\hline B3 & $\begin{array}{l}\text { Fragmentação, } \\
\text { destruição }\end{array}$ & $\begin{array}{l}\text { Perplexidade, } \\
\text { angústia } \\
\text { persecutória }\end{array}$ & $\begin{array}{c}\text { Cisão, } \\
\text { fragmentação }\end{array}$ & $\begin{array}{l}\text { Mutilação, } \\
\text { fragmentação }\end{array}$ & 1 \\
\hline BG & $\begin{array}{c}\text { Paralisar o } \\
\text { objeto ou self }\end{array}$ & $\begin{array}{l}\text { Ansiedade } \\
\text { confusional }\end{array}$ & $\begin{array}{l}\text { Negação, } \\
\text { confusão }\end{array}$ & Fusão, simbiose & $1-2$ \\
\hline $\mathrm{C} 2$ & $\begin{array}{l}\text { Fusão com o } \\
\text { objeto amado }\end{array}$ & Solidão, morte & $\begin{array}{l}\text { Controle de } \\
\text { objetos }\end{array}$ & $\begin{array}{l}\text { Fragmentação, } \\
\text { mutilação }\end{array}$ & 2 \\
\hline $\mathrm{Br}$ & $\begin{array}{c}\text { Fusão, } \\
\text { simbiose, } \\
\text { dependência }\end{array}$ & $\begin{array}{c}\text { Ansiedade, } \\
\text { persecutoriedade }\end{array}$ & $\begin{array}{l}\text { Imobilização, } \\
\text { clivagem }\end{array}$ & Destruir objeto & 1 \\
\hline & & & & & $\begin{array}{c}\mathrm{N}=7-10 \\
\text { Média }=1,5\end{array}$ \\
\hline
\end{tabular}

Aspectos manifestos: homem, riacho, foto, quadro, água (A1); pedras, água, riacho (AG); pai, filho, Santo Antônio; santuário, igreja (B3); crianças, internato (BG); mulher, casa, porta, janela (C2); nenhum aspecto manifesto (Branca). 
Análise: intenso sentimento de solidão é demonstrado na narrativa em A1. Evidente confusão e controle de objetos ao coisificar o homem e o transformar em objeto inanimado (foto).

Dificuldade em visualizar pessoas inteiras (B3), demonstra perplexidade em relação ao conteúdo mobilizado negando a situação triangular. Não integra figuras e vislumbra objetos parciais.

A realidade psíquica é negada diante da lâmina AG e não apresenta possibilidade de reparação egóica (desumaniza a cena, transforma em pedras).

Defende-se maniacamente do conteúdo que emerge em BG, ignora exclusão do personagem (nega) devido a intensa ansiedade provocada pela lâmina.

A ansiedade extrema está presente também na narrativa dirigida à lâmina $\mathrm{C} 2$. O personagem na cama é negado. Alguém volta para casa na solidão. Dificuldade em lidar com a perda ou em reconhecer aspectos destruídos do ego (e que precisam ser reparados).

Angustia-se diante da última lâmina (Branca) e se utiliza de defesas maníacas para manter o distanciamento afetivo (não entrar em contato com o mundo interno).

Equilíbrio não mantido com predomínio de ansiedade. Estabelece relações negativas ou muito negativas (relações de objeto parciais).

\section{- AVALIAÇÃO MULTIAXIAL - EIXO V - DSM-IV}

Escala de Avaliação Global do Funcionamento (AGF) - Pontuação: 30

Sérios prejuízos na comunicação e julgamento, incoerência, preocupação suicida (abandono). 


\section{PACIENTE 2}

Idade: 53 anos sexo: feminino

HD: IC (Insuficiência Cardíaca) - CMD - (Cardiomiopatia Dilatada)

Classe Funcional NYHA: CF IV

- ANÁLISE E INTERPRETAÇÃO DO TRO:

Quadro 35. Avaliação das lâminas - paciente 2 do grupo D:

\begin{tabular}{|c|c|c|c|c|c|}
\hline & \multicolumn{3}{|c|}{ STID } & \multirow{2}{*}{$\begin{array}{c}\text { Fantasia } \\
\text { Inconsciente } \\
\text { Dominante }\end{array}$} & \multirow[b]{2}{*}{ Pontos } \\
\hline & $\begin{array}{c}\text { Desejos } \\
\text { Inconscientes }\end{array}$ & $\begin{array}{c}\text { Medos / } \\
\text { Ansiedades }\end{array}$ & $\begin{array}{c}\text { Mecanismos } \\
\text { de Defesa }\end{array}$ & & \\
\hline A1 & Dependência & $\begin{array}{l}\text { Aniquilamento, } \\
\text { solidão }\end{array}$ & $\begin{array}{c}\text { Identificação } \\
\text { adesiva, } \\
\text { controle }\end{array}$ & Separação & 3 \\
\hline$A G$ & Simbiose & Persecutoriedade & $\begin{array}{c}\text { Negação, } \\
\text { controle } \\
\text { onipotente }\end{array}$ & $\begin{array}{c}\text { Fusão, } \\
\text { aglutinação }\end{array}$ & $1-2$ \\
\hline B3 & $\begin{array}{c}\text { Paralisar o } \\
\text { objeto ou self }\end{array}$ & Inveja & $\begin{array}{c}\text { Controle } \\
\text { onipotente }\end{array}$ & $\begin{array}{c}\text { Destruição do } \\
\text { objeto }\end{array}$ & 2 \\
\hline BG & Dependência & $\begin{array}{c}\text { Solidão, } \\
\text { desamparo }\end{array}$ & $\begin{array}{l}\text { Paralisação, } \\
\text { imobilização }\end{array}$ & Dependência & $1-2$ \\
\hline $\mathrm{C} 2$ & $\begin{array}{l}\text { Fusão com o } \\
\text { objeto amado }\end{array}$ & $\begin{array}{c}\text { Morte, } \\
\text { aniquilamento }\end{array}$ & $\begin{array}{c}\text { Clivagem, } \\
\text { escotomização }\end{array}$ & $\begin{array}{l}\text { Fragmentação, } \\
\text { mutilação }\end{array}$ & $1-2$ \\
\hline $\mathrm{Br}$ & $\begin{array}{l}\text { Fusão com o } \\
\text { objeto amado }\end{array}$ & $\begin{array}{c}\text { Morte, } \\
\text { aniquilamento }\end{array}$ & $\begin{array}{c}\text { Identificação } \\
\text { adesiva, } \\
\text { controle }\end{array}$ & Fragmentação & $1-2$ \\
\hline & & & & & $\begin{array}{c}\mathrm{N}=9-13 \\
\text { Média }=1,5-2\end{array}$ \\
\hline
\end{tabular}

Aspectos manifestos: pessoas, cachoeira (A1); pessoas, paisagem branca (AG); casal, pessoa, rei, rainha, porta (B3); homem, mulher, crianças, porta, janela (BG); mãe, filho, quarto, quadro, cômoda (C2); pessoas, paisagem, montanha, sol, mar, folha (Branca). 
Análise: demonstra ansiedade diante da primeira lâmina do teste, ampara-se da angústia inserindo um segundo personagem ao lado do principal, na tentativa de aplacar o sentimento de solidão que emergiu (A1).

O terceiro excluído é citado em B3, no entanto, caracterizado por sentimentos invejosos enquanto observa o casal. São projetados aspectos infantis e se afasta da situação a partir do controle onipotente (o casal é formado por um rei e uma rainha).

Dificuldade em lidar com perdas (AG) gera angústia persecutória e são projetadas pessoas orando, meditando em uma "paisagem branca". Reage defensivamente controlando a situação que mobilizaria aspectos de perda / luto.

Não é capaz de sentir depressivamente a situação imposta em C2, apesar de citar dois personagens (mãe e filhos). Na cena, estão distanciados afetivamente, não se vinculam. Descreve um contexto fragmentado, limitando-se a descrever objetos desconexos que foram visualizados. Isola-se do grupo (BG) em atitude observadora, porém não participativa, demonstrando dificuldade para reintegração ao meio.

Negação da realidade psíquica (Branca) e abdicação do momento de recomeço. Não é incluída na cena e traz a narrativa de objetos inanimados, desvitalizados.

Equilíbrio não mantido com predomínio de ansiedade. Estabelece relações negativas ou muito negativas. Utiliza-se de defesas características das fases mais arcaicas do desenvolvimento.

\section{- AVALIAÇÃO MULTIAXIAL - EIXO V - DSM-IV}

Escala de Avaliação Global do Funcionamento (AGF) - Pontuação: 35

Prejuízos na comunicação e humor, comprometimento significativo no teste de realidade. 


\section{PACIENTE 3}

Idade: 54 anos sexo: feminino

HD: IC (Insuficiência Cardíaca) - CMD (Cardiomiopatia Dilatada)

Classe Funcional NYHA: CF IV

- ANÁLISE E INTERPRETAÇÃO DO TRO:

Quadro 36. Avaliação das lâminas - paciente 3 do grupo D:

\begin{tabular}{|c|c|c|c|c|c|}
\hline & \multicolumn{3}{|c|}{ STID } & \multirow{2}{*}{$\begin{array}{c}\text { Fantasia } \\
\text { Inconsciente } \\
\text { Dominante }\end{array}$} & \multirow[b]{2}{*}{ Pontos } \\
\hline & $\begin{array}{c}\text { Desejos } \\
\text { Inconscientes }\end{array}$ & $\begin{array}{c}\text { Medos / } \\
\text { Ansiedades }\end{array}$ & $\begin{array}{l}\text { Mecanismos } \\
\text { de Defesa }\end{array}$ & & \\
\hline A1 & $\begin{array}{c}\text { Separar } \\
\text { objeto bom e } \\
\text { mau }\end{array}$ & Solidão & $\begin{array}{c}\text { Identificação } \\
\text { projetiva e } \\
\text { introjetiva }\end{array}$ & Integração & $3-4$ \\
\hline AG & $\begin{array}{c}\text { Paralisar o } \\
\text { objeto ou self }\end{array}$ & Persecutoriedade & $\begin{array}{l}\text { Controle } \\
\text { onipotente }\end{array}$ & Paralisação & 2 \\
\hline B3 & $\begin{array}{l}\text { Fusão com o } \\
\text { objeto amado }\end{array}$ & $\begin{array}{c}\text { Ansiedade, } \\
\text { persecutoriedade }\end{array}$ & Escotomização & Fusão, simbiose & 2 \\
\hline BG & $\begin{array}{c}\text { Proteger do } \\
\text { aniquilamento }\end{array}$ & $\begin{array}{c}\text { Morte, } \\
\text { aniquilamento }\end{array}$ & $\begin{array}{l}\text { Introjeção do } \\
\text { bom objeto }\end{array}$ & $\begin{array}{c}\text { Perda e } \\
\text { elaboração do } \\
\text { luto }\end{array}$ & $4-5$ \\
\hline $\mathrm{C} 2$ & $\begin{array}{c}\text { Paralisar o } \\
\text { objeto ou self }\end{array}$ & $\begin{array}{c}\text { Angústia, } \\
\text { persecutoriedade }\end{array}$ & $\begin{array}{l}\text { Controle } \\
\text { onipotente }\end{array}$ & $\begin{array}{c}\text { Morte, } \\
\text { desaparecimento }\end{array}$ & $2-3$ \\
\hline $\mathrm{Br}$ & $\begin{array}{l}\text { Reparar o } \\
\text { objeto }\end{array}$ & $\begin{array}{l}\text { Luto pela } \\
\text { destruição }\end{array}$ & $\begin{array}{l}\text { Reparação } \\
\text { maníaca }\end{array}$ & $\begin{array}{c}\text { Perda e } \\
\text { elaboração do } \\
\text { luto }\end{array}$ & $5-6$ \\
\hline & & & & & $\begin{array}{c}\mathrm{N}=18-22 \\
\text { Média }=3-3,5\end{array}$ \\
\hline
\end{tabular}

Aspectos manifestos: homem, criança, cachoeira, nuvens (A1); pessoas flutuando, pasto (AG); casal, vaso árabe, porta (B3); padre, fiéis, igreja, arco, janela (BG); pessoa, cama, quadro, porta, quarto (C2); marido, filhos, paciente, rio, pedras, água, céu azul, nuvens, quadro (Branca). 
Análise: a busca por integração é manifestada diante da primeira lâmina (A1) na qual o homem e a criança olham para a mesma direção. Apesar da situação imposta pela lâmina (solidão, medo do desconhecido), sente-se amparada neste momento.

A configuração triangular é negada (B3) e o terceiro não incluído na relação objetal é transformado em um vaso. O personagem é desumanizado e se estabelece um vínculo simbiótico na cena.

É originada uma história de fantasmas / espíritos (AG) devido intensa ansiedade persecutória que a impediu de sentir depressivamente os conteúdos internos que foram mobilizados.

O personagem vislumbrado em $\mathrm{BG}$ está afastado dos demais: há relação de superioridade, porém, oram juntos, ao mesmo tempo. Demonstra capacidade de reintegração ao grupo. Demonstra intensa ansiedade (C2) ao visualizar a mulher acamada. Reage ao estímulo maniacamente, negando a situação ou controlando onipotentemente o fim da história (abreviando narrativa). Recusa-se a intitular.

Manifesta a possibilidade de reparação / recuperação através de elaboração depressiva (Branca), com aceitação do sofrimento e condições internas para tolerar o processo saúde doença (dispondo de partes do ego integradas).

Tendência adaptativa, com possibilidade de manter o equilíbrio e estabelecer relações positivas.

\section{- AVALIAÇÃO MULTIAXIAL - EIXO V - DSM-IV}

Escala de Avaliação Global do Funcionamento (AGF) - Pontuação: 60

Sintomas moderados, muitos são previsíveis a estressores psicossociais. Apresenta oscilações de humor e insônia. Mantém relacionamentos interpessoais significativos. 


\section{PACIENTE 4}

Idade: 54 anos sexo: feminino

HD: IC (Insuficiência Cardíaca) - CCC (Cardiomiopatia Chagásica Crônica)

Classe Funcional NYHA: CF IV

- ANÁLISE E INTERPRETAÇÃO DO TRO:

Quadro 37. Avaliação das lâminas - paciente 4 do grupo D:

\begin{tabular}{|c|c|c|c|c|c|}
\hline & \multicolumn{3}{|c|}{ STID } & \multirow{2}{*}{$\begin{array}{c}\text { Fantasia } \\
\text { Inconsciente } \\
\text { Dominante }\end{array}$} & \multirow[b]{2}{*}{ Pontos } \\
\hline & $\begin{array}{c}\text { Desejos } \\
\text { Inconscientes }\end{array}$ & $\begin{array}{c}\text { Medos / } \\
\text { Ansiedades }\end{array}$ & $\begin{array}{c}\text { Mecanismos } \\
\text { de Defesa }\end{array}$ & & \\
\hline A1 & $\begin{array}{c}\text { Separar } \\
\text { objeto bom e } \\
\text { mau }\end{array}$ & $\begin{array}{c}\text { Solidão, } \\
\text { desamparo }\end{array}$ & $\begin{array}{l}\text { Identificação } \\
\text { projetiva }\end{array}$ & Separação & 3 \\
\hline$A G$ & $\begin{array}{c}\text { Paralisar o } \\
\text { objeto ou self }\end{array}$ & $\begin{array}{l}\text { Persecutoriedade, } \\
\text { medo do } \\
\text { aniquilamento }\end{array}$ & Confusão & $\begin{array}{l}\text { Mutilação, } \\
\text { fragmentação }\end{array}$ & $1-2$ \\
\hline B3 & $\begin{array}{l}\text { Fusão com o } \\
\text { objeto amado }\end{array}$ & $\begin{array}{l}\text { Ansiedade } \\
\text { confusional }\end{array}$ & Escotomização & Fusão, simbiose & $1-2$ \\
\hline BG & $\begin{array}{c}\text { Paralisar o } \\
\text { objeto ou self }\end{array}$ & $\begin{array}{l}\text { Ansiedade } \\
\text { confusional }\end{array}$ & $\begin{array}{l}\text { Clivagem, } \\
\text { negação }\end{array}$ & $\begin{array}{l}\text { Mutilação, } \\
\text { fragmentação }\end{array}$ & 2 \\
\hline $\mathrm{C} 2$ & $\begin{array}{c}\text { Paralisar o } \\
\text { objeto ou self }\end{array}$ & $\begin{array}{c}\text { Morte, } \\
\text { aniquilamento }\end{array}$ & $\begin{array}{c}\text { Controle } \\
\text { onipotente, } \\
\text { negação }\end{array}$ & Aniquilamento & $2-3$ \\
\hline $\mathrm{Br}$ & $\begin{array}{l}\text { Paralisar o } \\
\text { objeto ou self }\end{array}$ & $\begin{array}{l}\text { Ansiedade } \\
\text { confusional }\end{array}$ & Escotomização & $\begin{array}{l}\text { Destruição do } \\
\text { objeto }\end{array}$ & 2 \\
\hline & & & & & $\begin{array}{c}\mathrm{N}=11-15 \\
\text { Média }=2-2,5\end{array}$ \\
\hline
\end{tabular}

Aspectos manifestos: homens, cachoeira, paisagem (A1); homem, tempo, cabelo, sobrancelha, rosto, cabeça (AG); casal, manto, lenços, cobertor, imagem, estátua (B3); 
pessoas, igreja, porta, janela, olho (BG); pessoa, porta, velas, quadro, cama, lençol (C2); paciente, filha, família, churrasqueira (Branca).

Análise: apesar de acompanhado, o personagem principal em A1 está abaixado e "não liga para nada, não se importa”. A angústia que emerge a faz se distanciar afetivamente da situação de teste imposta.

Negação da realidade psíquica (B3) transforma o terceiro em objeto inanimado. Ignora configuração triangular e demonstra vínculo simbiótico estabelecido na figura do casal.

Sente a angústia (AG) e se defende maniacamente, criando uma figura confusa, negando a situação apresentada e evitando o contato com perdas. Vislumbra partes cindidas / fragmentadas na cena.

Estado confusional em BG origina história com fragmentos de corpo (olho). Repara a destruição ao final, reintegrando o personagem isolado ao grupo (passa a pertencer ao grupo).

A realidade da morte é negada $(\mathrm{C} 2)$ ao projetar um lençol próximo à duas velas e ignorar a pessoa acamada. Intensa ansiedade foi mobilizada, levando-a a controlar onipotentemente a situação apresentada. (Existem indícios de morte, mas não há corpo).

Ao final, banaliza (Branca) afirmando que tudo é uma ilusão. Mesmo com a criação de uma história que poderia gratificar, esta seria uma "ilusão, porque não é possível, não há nada aqui”.

Equilíbrio não mantido. Ansiedade é predominante, bem como relações negativas

\section{- AVALIAÇÃO MULTIAXIAL - EIXO V - DSM-IV}

Escala de Avaliação Global do Funcionamento (AGF) - Pontuação: 38

Prejuízos no teste de realidade e comunicação. Sintomas moderados, humor depressivo, afeto embotado. Dificuldade no funcionamento social / ocupacional. 


\section{PACIENTE 5}

Idade: 32 anos sexo: feminino

HD: IC (Insuficiência Cardíaca) - CR (Cardiopatia Reumática)

Classe Funcional NYHA: CF IV

- ANÁLISE E INTERPRETAÇÃO DO TRO:

Quadro 38. Avaliação das lâminas - paciente 5 do grupo D:

\begin{tabular}{|c|c|c|c|c|c|}
\hline & \multicolumn{3}{|c|}{ STID } & \multirow{2}{*}{$\begin{array}{c}\text { Fantasia } \\
\text { Inconsciente } \\
\text { Dominante }\end{array}$} & \multirow[b]{2}{*}{ Pontos } \\
\hline & $\begin{array}{c}\text { Desejos } \\
\text { Inconscientes }\end{array}$ & $\begin{array}{c}\text { Medos / } \\
\text { Ansiedades }\end{array}$ & $\begin{array}{l}\text { Mecanismos } \\
\text { de Defesa }\end{array}$ & & \\
\hline A1 & $\begin{array}{l}\text { Ser olhada, } \\
\text { notada }\end{array}$ & $\begin{array}{l}\text { Solidão, morte e } \\
\text { abandono }\end{array}$ & $\begin{array}{c}\text { Identificação } \\
\text { projetiva }\end{array}$ & Fusão, simbiose & $2-3$ \\
\hline AG & $\begin{array}{c}\text { Dependência, } \\
\text { paralisar o } \\
\text { objeto ou self } \\
\end{array}$ & $\begin{array}{c}\text { Ansiedade } \\
\text { confusional, } \\
\text { aniquilamento }\end{array}$ & $\begin{array}{c}\text { Controle de } \\
\text { objetos, } \\
\text { escotomização } \\
\end{array}$ & $\begin{array}{c}\text { Destruição, } \\
\text { desaparecimento } \\
\text { do self }\end{array}$ & $1-2$ \\
\hline B3 & Dependência & $\begin{array}{c}\text { Inveja, } \\
\text { desamparo }\end{array}$ & $\begin{array}{l}\text { Desapareciment } \\
\quad \text { o do self }\end{array}$ & Paralisação & 2 \\
\hline BG & $\begin{array}{c}\text { Separar } \\
\text { objeto bom e } \\
\text { mau } \\
\end{array}$ & $\begin{array}{c}\text { Medo de } \\
\text { progredir, crescer }\end{array}$ & $\begin{array}{c}\text { Identificação } \\
\text { projetiva e } \\
\text { introjetiva } \\
\end{array}$ & Separação & 3 \\
\hline $\mathrm{C} 2$ & $\begin{array}{l}\text { Fusão com o } \\
\text { objeto amado }\end{array}$ & $\begin{array}{l}\text { Autodesvalori- } \\
\text { zação }\end{array}$ & Escotomização & $\begin{array}{l}\text { Fragmentação, } \\
\text { aniquilamento }\end{array}$ & $1-2$ \\
\hline $\mathrm{Br}$ & $\begin{array}{c}\text { Paralisar o } \\
\text { objeto ou self }\end{array}$ & Aniquilamento & $\begin{array}{l}\text { Idealização, } \\
\text { triunfo }\end{array}$ & $\begin{array}{c}\text { Morte, } \\
\text { desaparecimento }\end{array}$ & $2-3$ \\
\hline & & & & & $\begin{array}{c}\mathrm{N}=11-15 \\
\text { Média }=2-2,5\end{array}$ \\
\hline
\end{tabular}

Aspectos manifestos: pessoas, homem, criança, morte, árvore (A1); pessoas, sombra, morro (AG); marido, menino, mãe, porta, escuridão (B3); rapazes, sombra, janela, porta, calçada (BG); marido, paciente, filha, foto (C2); claridade, nuvens brancas, ovelhas (Branca). 
Análise: em atitude regressiva, inclui uma criança (A1) que está na escuridão da noite, sozinha, enquanto o homem observa calado e distante. A criança não é acolhida, manifestando intenso sentimento de solidão.

Considera a situação triangular, porém "a mãe está de costas para a criança, não liga”. Sente-se só, abandonada, não identifica o olhar da mãe (B3).

Dificuldade para elaborar perdas é identificada (AG). Sugere que a lâmina seja pintada / colorida para que "fique melhor". Nega o conteúdo e controla objetos, encerrando bruscamente a narrativa. Aceita o distanciamento em um personagem do grupo (BG) e o coloca em posição de igualdade frente a seus pares. Identifica-se projetivamente e apresenta fragilidade egóica ao afirmar que "é sombra" ou "faz sombra, reflexo".

Aceita mulher acamada em C2, utilizando-se, novamente, do mecanismo de identificação projetiva. Recorda-se de cena de seu cotidiano e se projeta grávida na cena, negando psiquicamente sua condição atual de saúde (não pode engravidar), demonstrando dificuldade em lidar com suas perdas (doença).

Cria história que gratifica (Branca), indicando a morte como saída para seu sofrimento. A lâmina foi descrita como "entrada no paraíso". Este seria seu projeto existencial, a única alternativa possível.

Pontos de fixação da libido na fase oral do desenvolvimento. Predomínio de ansiedade, não mantém o equilíbrio adaptativo e estabelece relações negativas.

\section{- AVALIAÇÃO MULTIAXIAL - EIXO V - DSM-IV}

Escala de Avaliação Global do Funcionamento (AGF) - Pontuação: 36

Prejuízos importantes em diversas áreas (contato com a realidade, comunicação, autocuidado, julgamento). Apresenta aspectos destrutivos. 


\section{PACIENTE 6}

Idade: 47 anos sexo: feminino

HD: IC (Insuficiência Cardíaca) - CMD (Cardiomiopatia Dilatada)

Classe Funcional NYHA: CF IV

- ANÁLISE E INTERPRETAÇÃO DO TRO:

Quadro 39. Avaliação das lâminas - paciente 6 do grupo D:

\begin{tabular}{|c|c|c|c|c|c|}
\hline & \multicolumn{3}{|c|}{ STID } & \multirow{2}{*}{$\begin{array}{c}\text { Fantasia } \\
\text { Inconsciente } \\
\text { Dominante }\end{array}$} & \multirow[b]{2}{*}{ Pontos } \\
\hline & $\begin{array}{c}\text { Desejos } \\
\text { Inconscientes }\end{array}$ & $\begin{array}{c}\text { Medos / } \\
\text { Ansiedades }\end{array}$ & $\begin{array}{l}\text { Mecanismos } \\
\text { de Defesa }\end{array}$ & & \\
\hline A1 & $\begin{array}{l}\text { Ser olhada, } \\
\text { notada }\end{array}$ & Solidão & $\begin{array}{c}\text { Identificação } \\
\text { projetiva }\end{array}$ & $\begin{array}{c}\text { Morte, } \\
\text { desaparecimento }\end{array}$ & $2-3$ \\
\hline AG & $\begin{array}{c}\text { Paralisar o } \\
\text { objeto ou self }\end{array}$ & $\begin{array}{l}\text { Persecutoriedade, } \\
\text { ansiedade } \\
\text { confusional }\end{array}$ & $\begin{array}{l}\text { Idealização, } \\
\text { escotomização, } \\
\text { controle }\end{array}$ & $\begin{array}{l}\text { Mutilação, } \\
\text { fragmentação }\end{array}$ & $1-2$ \\
\hline B3 & Simbiose & $\begin{array}{c}\text { Inveja, } \\
\text { persecutoriedade }\end{array}$ & $\begin{array}{l}\text { Clivagem, } \\
\text { negação }\end{array}$ & $\begin{array}{c}\text { Mutilação, } \\
\text { fragmentação, } \\
\text { cisão }\end{array}$ & 2 \\
\hline BG & $\begin{array}{c}\text { Separar } \\
\text { objeto bom e } \\
\text { mau }\end{array}$ & $\begin{array}{l}\text { Medo de } \\
\text { progredir }\end{array}$ & $\begin{array}{l}\text { Introjeção do } \\
\text { bom objeto }\end{array}$ & Separação & $3-4$ \\
\hline $\mathrm{C} 2$ & $\begin{array}{l}\text { Destruição do } \\
\text { objeto }\end{array}$ & $\begin{array}{l}\text { Aniquilamento, } \\
\text { persecutoriedade }\end{array}$ & Escotomização & Paralisação & 2 \\
\hline $\mathrm{Br}$ & $\begin{array}{c}\text { Paralisar o } \\
\text { objeto ou self }\end{array}$ & Persecutoriedade & $\begin{array}{l}\text { Controle de } \\
\text { objetos, } \\
\text { imobilização }\end{array}$ & Fragmentação & 2 \\
\hline & & & & & $\begin{array}{c}\mathrm{N}=12-15 \\
\text { Média }=2-2,5\end{array}$ \\
\hline
\end{tabular}

Aspectos manifestos: homem, criança, mulher, lugar triste (A1); conteúdo humano negado, golfinhos, bico de golfinho, pássaros (AG); noivo, noiva, pessoas, casa, festa (B3); 
pessoas, crianças, igreja, janela (BG); homem, pessoa, casa, porta, cama, colcha, cômoda, janela (C2); paciente, irmã, rodoviária (Branca).

Análise: insere criança desamparada na cena em A1, está “triste e sozinha” enquanto o pai (também triste) a observa de longe. Sentimento de solidão neste momento.

Persecutoriedade acentuada leva à negação da configuração triangular (B3). O casal estabelece uma relação simbiótica (objetos parciais) e são inseridos personagens que seguem os noivos (objetos perseguidores, perigosos).

A ansiedade persecutória é mantida em AG. A narrativa traz o conteúdo da lâmina transformado em "golfinhos e pássaros alegres", negando aspectos de perda / morte que seriam mobilizados. Ansiedade confusional e idealização extrema são projetadas na cena, além de parte de um corpo fragmentado.

Refere personagem diferenciado em BG e não lhe atribui superioridade, demonstrando capacidade interna para reintegração ao meio (acolhimento).

Negação da morte a impede de visualizar mulher acamada (C2). O homem quer entrar na casa, mas não consegue, indicando dificuldade em lidar com sua condição atual de saúde (perdas), preferindo abandonar / escotomizar cena.

Nega a existência de um mundo interno (Branca) e se defende controlando objetos maus e perseguidores. Indica possibilidade de atingir adaptação, no entanto, não mantém o equilíbrio adaptativo e há predomínio de ansiedade com resultante negativa.

\section{- AVALIAÇÃO MULTIAXIAL - EIXO V - DSM-IV}

Escala de Avaliação Global do Funcionamento (AGF) - Pontuação: 40

Algum prejuízo no teste de realidade, comunicação e humor, bem como na capacidade de julgamento. 


\section{PACIENTE 7}

Idade: 47 anos sexo: feminino

HD: IC (Insuficiência Cardíaca) - CMD (Cardiomiopatia Dilatada)

Classe Funcional NYHA: CF IV

- ANÁLISE E INTERPRETAÇÃO DO TRO:

Quadro 40. Avaliação das lâminas - paciente 7 do grupo D:

\begin{tabular}{|c|c|c|c|c|c|}
\hline & \multicolumn{3}{|c|}{ STID } & \multirow{2}{*}{$\begin{array}{c}\text { Fantasia } \\
\text { Inconsciente } \\
\text { Dominante }\end{array}$} & \multirow[b]{2}{*}{ Pontos } \\
\hline & $\begin{array}{c}\text { Desejos } \\
\text { Inconscientes }\end{array}$ & $\begin{array}{c}\text { Medos / } \\
\text { Ansiedades }\end{array}$ & $\begin{array}{l}\text { Mecanismos } \\
\text { de Defesa }\end{array}$ & & \\
\hline A1 & Dependência & $\begin{array}{l}\text { Angústia } \\
\text { confusional }\end{array}$ & Idealização & $\begin{array}{l}\text { Fragmentação, } \\
\text { separação }\end{array}$ & 2 \\
\hline $\mathrm{AG}$ & $\begin{array}{c}\text { Paralisar o } \\
\text { objeto ou self }\end{array}$ & $\begin{array}{l}\text { Ansiedade } \\
\text { persecutória }\end{array}$ & $\begin{array}{c}\text { Ausência de } \\
\text { sentido, } \\
\text { confusão }\end{array}$ & $\begin{array}{c}\text { Morte, } \\
\text { fragmentação }\end{array}$ & 2 \\
\hline B3 & $\begin{array}{l}\text { Fusão, } \\
\text { simbiose }\end{array}$ & $\begin{array}{l}\text { Aniquilamento, } \\
\text { inveja }\end{array}$ & $\begin{array}{c}\text { Negação / } \\
\text { escotomização, } \\
\text { controle } \\
\end{array}$ & Fragmentação & $1-2$ \\
\hline $\mathrm{BG}$ & $\begin{array}{c}\text { Olhar e ser } \\
\text { olhada }\end{array}$ & Solidão & $\begin{array}{c}\text { Identificação } \\
\text { projetiva }\end{array}$ & Separação & $2-3$ \\
\hline $\mathrm{C} 2$ & $\begin{array}{c}\text { Paralisar o } \\
\text { objeto ou self }\end{array}$ & $\begin{array}{l}\text { Angústia } \\
\text { confusional }\end{array}$ & Escotomização & $\begin{array}{c}\text { Morte, } \\
\text { desaparecimento } \\
\text { do self }\end{array}$ & $1-2$ \\
\hline $\mathrm{Br}$ & $\begin{array}{c}\text { Reparar o } \\
\text { objeto }\end{array}$ & $\begin{array}{c}\text { Angústia } \\
\text { depressiva }\end{array}$ & $\begin{array}{l}\text { Introjeção do } \\
\text { bom objeto }\end{array}$ & $\begin{array}{c}\text { Perda e } \\
\text { elaboração do } \\
\text { luto }\end{array}$ & $4-5$ \\
\hline & & & & & $\begin{array}{c}\mathrm{N}=12-16 \\
\text { Média=2-2,5 }\end{array}$ \\
\hline
\end{tabular}

Aspectos manifestos: homem, criança, céu, Deus (A1); pessoas, reunião, céu, anjos (AG); casal, quarto, casa (B3); crianças, janela, porte, pista (BG); pessoa, casa, quadro, cama (C2); senhora, manchas, casa de repouso, chácara, pássaros, árvore, leite de vaca, rede para descanso (Branca). 
Análise: estado confusional diante da primeira lâmina, demonstrando dificuldade em lidar com aspectos de solidão que emergiram (A1). Insere na cena uma criança que, assim como o homem, olha para o céu e oram para que "voltem".

Onipotentemente controla a situação de doença e recebe alta (B3). Sentimento de ambivalência a mantém no escuro. Nega a relação triangular e indica inveja do casal que "vai embora”. A dificuldade em lidar com perdas / morte é verificada ao narrar um céu repleto de anjos (AG) que participam de uma reunião. Não sente depressivamente o conteúdo da lâmina apresentada.

Admite a criança isolada do grupo e não atribui a seus pares uma conotação de autoridade. Todos olham para uma direção comum $(\mathrm{BG})$, demonstrando capacidade de integração ao grupo (sente o acolhimento).

Ignora personagem na cama negando a realidade da morte $(\mathrm{C} 2)$. O personagem que entra no quarto olha para o quadro. Não faz referência à situação de doença / morte que seria estimulada pela lâmina e se defende maniacamente, impedindo a mobilização de conteúdos internos. Narra uma casa de repouso como solução para o sofrimento vivido (Branca). Abandona a realidade e encontra nesta casa um momento de descanso, sentindo depressivamente o conteúdo que emergiu.

Poderá atingir adaptação. No momento, não mantém o equilíbrio e há predomínio de ansiedade.

\section{- AVALIAÇÃO MULTIAXIAL - EIXO V - DSM-IV}

Escala de Avaliação Global do Funcionamento (AGF) - Pontuação: 51

Sintomas moderados, embotamento afetivo e alguma dificuldade no funcionamento social. 


\subsection{RESULTADOS - PARTE II}

\section{- Relações Objetais:}

Avaliação das relações objetais predominantes nos grupos estudados a partir da análise da tríade metapsicológica, formada por sentimentos (medos, angústias, sensações de persecutoriedade e confusão), desejos inconscientes e mecanismos de defesa:

\section{GRUPO A:}

Tabela 4. Relações Objetais - Grupo A

\begin{tabular}{cc}
\hline & Frequência das Relações de Objeto \\
\hline $\begin{array}{c}\text { Posição Viscocárica } \\
\text { (Gliscrocárica) } \\
\text { Posição } \\
\text { Esquizoparanóide } \\
\text { Posição } \\
\text { Depressiva }\end{array}$ \\
\hline
\end{tabular}

Os pacientes que não apresentam evidência de doença cardiovascular e que buscaram análise pessoal (grupo A) estabelecem relações objetais, predominantemente, das posições esquizoparanóide e depressiva, apresentando melhor capacidade de reparação em relação aos demais grupos estudados.

O grupo A obteve média de 4,0 - 4,5 pontos no TRO, referentes à classificação e seriação do equilíbrio adaptativo, com variação de 52 - 80 pontos no Eixo V (AGF).

Entre os menos capazes de manter o equilíbrio adaptativo, então os pacientes 1 e 8 , apresentando pontuações inferiores a 4,0 no TRO e 52 e 56 pontos na AGF, respectivamente. São identificados aspectos dissociativos e distanciamento afetivo nos pacientes 7 e 9. 
No geral, apresentaram condições de atingirem relações de objeto totais com o sentimento de depressão e diminuição da fragmentação, retificando fantasias e atingindo o processo de elaboração depressiva no decorrer do exame.

Os resultados sugerem que são capazes de manter o equilíbrio e que podem promover relações positivas (tendência adaptativa).

\section{GRUPO B:}

Tabela 5. Relações Objetais - Grupo B

\begin{tabular}{cc}
\hline & Frequência das Relações de Objeto \\
\hline $\begin{array}{c}\text { Posição Viscocárica } \\
\text { (Gliscrocárica }) \\
\text { Posição } \\
\text { Esquizoparanóide } \\
\text { Posição } \\
\text { Depressiva }\end{array}$ & $21,8 \%$ \\
\hline
\end{tabular}

Os pacientes CF I ou II (NYHA) provenientes de ambulatório de IC estabelecem relações objetais, predominantemente, da posição esquizoparanóide, com alguma frequência de relações de objeto das fases viscocárica e depressiva.

O grupo $\mathrm{B}$ obteve média de 3,0 - 3,5 pontos no TRO, referentes à classificação e seriação do equilíbrio adaptativo, com variação de 40 - 71 pontos no Eixo V (AGF).

Relações de objeto parciais com possibilidade de atingirem totais são verificadas entre os pacientes 1, 4, 5, 6, 7 e 9 que atingiram a elaboração do luto na lâmina Branca.

O paciente 3 demonstra possibilidade de conquistar a reparação objetal, no entanto, mantém o predomínio de relações objetais características da fase esquizoparanóide. Os pacientes 2, 8 e 10 mantém frequencia significativa de relações simbióticas e desejos 
inconscientes de fusão com o objeto. Defesas da fase viscocárica do desenvolvimento são identificadas. O momento da separação (lâmina Branca) gera ansiedade, principalmente, entre os pacientes 7 e 8 .

Os resultados sugerem que há tendência adaptativa (podem atingir o equilíbrio adaptativo), mas estabelecem relações tanto positivas quanto negativas.

\section{GRUPO C:}

Tabela 6. Relações Objetais - Grupo C

\begin{tabular}{cc}
\hline & Frequência das Relações de Objeto \\
\hline $\begin{array}{c}\text { Posição Viscocárica } \\
\text { (Gliscrocárica }) \\
\text { Posição } \\
\text { Esquizoparanóide } \\
\text { Posição } \\
\text { Depressiva }\end{array}$ & $34 \%$ \\
\hline
\end{tabular}

Os pacientes CF III ou IV (NYHA) internados em enfermaria de pronto socorro estabelecem relações objetais predominantemente da posição esquizoparanóide, com frequência significativa de relações de objeto da fase viscocárica.

O grupo $\mathrm{C}$ obteve média de 2,5 pontos no TRO, referentes à classificação e seriação do equilíbrio adaptativo, com variação de 33 - 59 pontos no Eixo V (AGF).

Relações objetais predominantemente parciais são identificadas nos pacientes 5,8 e 10, com pontuações inferiores a 2,0 no TRO e avaliação de Eixo V (AGF) de 33 e 38 pontos, respectivamente.

Os pacientes $1,4,6,7,9,11$ e 13 atingiram pontuações que variaram entre 38 e 59 pontos no Eixo V (AGF) e entre 2,0 e 2,5 pontos no TRO, sendo que, os pacientes 1, 4 e 6 
demonstraram tentativa de reparação (principalmente na última lâmina do TRO - pacientes 4 e 6). A manutenção de desejos inconscientes, medos / ansiedades e mecanismos de defesa arcaicos é verificada, principalmente, nos pacientes 9 e 11. A paciente 7 manifesta características mais evidentes de depressão.

Sintomas moderados e tendência adaptativa diferenciada são identificados nos pacientes 2, 3 e 12, com pontuações no TRO variando de 2,5 a 3,0 pontos e entre 51 e 58 pontos no Eixo V (AGF).

Os resultados sugerem que o equilíbrio adaptativo não foi mantido, há predomínio de ansiedade e relações negativas, mas com possível tendência adaptativa.

\section{GRUPO D:}

Tabela 7. Relações Objetais - Grupo D

Frequência das Relações de Objeto

\begin{tabular}{cc}
\hline $\begin{array}{c}\text { Posição Viscocárica } \\
\text { (Gliscrocárica) }\end{array}$ & $39,3 \%$ \\
Posição & \\
Esquizoparanóide & $47,7 \%$ \\
Posição & \\
Depressiva & $13 \%$ \\
\hline
\end{tabular}

Os pacientes CF III ou IV (NYHA) indicados ao TC estabelecem relações objetais predominantemente da posição esquizoparanóide, com frequência quase similar de relações de objeto da fase viscocárica.

O grupo D obteve média de 2,5 pontos no TRO, referentes à classificação e seriação do equilíbrio adaptativo. A pontuação é semelhante à do grupo anterior, porém, foram mais 
frequentes os desejos inconscientes, medos / ansiedades e mecanismos de defesa da posição viscocárica. A pontuação da avaliação de Eixo V (AGF) variou entre 30 e 60 pontos.

As pacientes 1 e 2 demonstram relações de objeto características da fase viscocárica do desenvolvimento, com pontuações inferiores a 1,5 no TRO e avaliação de Eixo V (AGF) de 30 e 35 pontos, respectivamente, seguidas da pacientes 4 e 5, com pontuação entre 2,0 e 2,5 pontos no TRO.

Condições mais favoráveis para a conquista de relações menos parciais são identificadas nas pacientes 3,6 e 7, principalmente na paciente 3 , capaz de sentir a perda e atingir a elaboração do luto na última lâmina do teste.

Os resultados sugerem que o equilíbrio adaptativo não foi mantido, há predomínio de ansiedade e relações negativas.

A tabela 8 demonstra o Sistema Tensional Inconsciente Dominante dos grupos estudados.

Tabela 8. STID dos Grupos A, B, C e D

\begin{tabular}{|c|c|c|c|c|}
\hline & \multicolumn{4}{|c|}{ Sistema Tensional Inconsciente Predominante } \\
\hline & Grupo A & Grupo B & Grupo C & Grupo D \\
\hline $\begin{array}{l}\text { Posição Viscocárica } \\
\text { (Gliscrocárica) }\end{array}$ & $7,3 \%$ & $21,8 \%$ & $34 \%$ & $39,3 \%$ \\
\hline $\begin{array}{c}\text { Posição } \\
\text { Esquizoparanóide }\end{array}$ & $55,4 \%$ & $51,6 \%$ & $51 \%$ & $47,7 \%$ \\
\hline $\begin{array}{c}\text { Posição } \\
\text { Depressiva }\end{array}$ & $37,3 \%$ & $26,5 \%$ & $15 \%$ & $13 \%$ \\
\hline
\end{tabular}


Nos grupos C e D, apesar do predomínio da parcialidade da posição esquizoparanóide, a frequência das relações objetais da fase viscocárica do desenvolvimento foi maior, em relação aos grupos A e B.

\section{- Fantasias Inconscientes}

Fantasias inconscientes de morte são verificadas em todos os grupos.

No grupo A, foram frequentes as fantasias de abandono / solidão, predominando as fantasias de morte, perda e elaboração do luto.

Fantasias de fragmentação e paralisação foram predominantes no grupo B, seguidas por fantasias de morte, perda e elaboração do luto.

No grupo C, predominaram as fantasias inconscientes de paralisação e morte, além das FI de fusão, seguidas por separação e destruição do objeto.

Fantasias inconscientes de mutilação e retaliação foram frequentes no grupo D, seguidas por fragmentação e fusão / simbiose. 


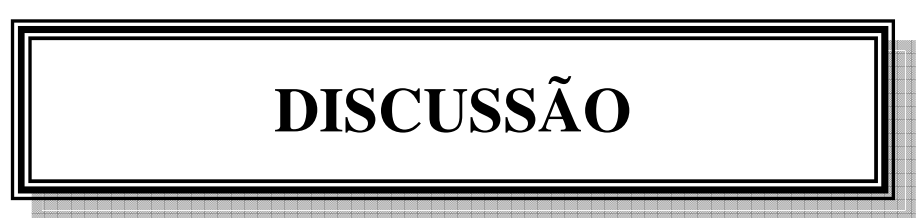




\section{DISCUSSÃO}

"Existem momentos na vida da gente, em que as palavras perdem o sentido ou parecem inúteis, $e$, por mais que a gente pense numa forma de empregá-las, elas parecem não servir. Então a gente não diz, apenas sente."

Freud, $S$.

Os resultados desta pesquisa demonstraram a psicodinâmica dos pacientes em diferentes estágios de DCV e daqueles que não apresentam evidência da doença.

A comparação entre os grupos permitiu identificar os processos psíquicos envolvidos nos diagnósticos abordados. Possibilitou, ainda, confirmar a importância da identificação / construção de demanda para estes pacientes, o que implicaria em ressaltar (colocar à mostra, tornar consciente) o sofrimento psíquico implícito na condição clínica vivenciada, ou seja, no processo saúde - doença, especialmente na DCV.

O TRO (Phillipson, 1981) e a avaliação de Eixo V - AGF / DSM IV (Associação Americana de Psiquiatria [APA], 2002) foram interpretados segundo a análise da entrevista clínica, com informações sobre a história pessoal e condição física atual do paciente. Os achados dizem sobre os conteúdos latentes do discurso e que emergem no exame.

A análise das relações objetais e fantasias inconscientes seguiu os conceitos da teoria psicanalítica de Melanie Klein sobre posições (Klein, 1948, 1991a, 1991b, 1991c, 1991d, 1996a, 1996b, 1997a, 1997b).

As histórias do TRO foram avaliadas de acordo com Phillipson (1981), Ocampo (1991) e Rosa (2005) e pontuadas segundo os dados sobre o STID, seguindo o protocolo de análise e interpretação do teste (Apêndice A). 


\section{- Das Relações Objetais...}

GRUPO A - média 4,0 - 4,5 pontos no TRO e variação de 52 a 80 pontos na AGF

Alguns pacientes se mostraram menos capazes de manter o equilíbrio adaptativo (pacientes 1 e 8), apresentando pontuação inferior a 4 no teste projetivo, porém com condições de reparação verificadas ao final do exame. Os resultados corroboram com o material da entrevista clínica:

O paciente 1 (T. Pânico - Ansiedade Generalizada) referiu que sempre apresentou sintomas, desde a infância (e tem recordações precisas), mas que estes se agravaram com o término de um namoro. Relatou intenso sofrimento com o rompimento, acentuado pela exposição do conflito, pelo ex - companheiro, nas redes sociais. "Não tive tempo de contar o ocorrido para os meus amigos, não consegui falar... Eles me perguntavam o que havia acontecido, mas eu ainda não estava preparado para discutir o assunto, senti essa pressão como uma agressão". Manifesta dificuldade para conversar com os pais sobre sua orientação homossexual, "já tentei contar algumas vezes, mas não me escutam, ignoram o que falo, vivo uma mentira em casa”. Há exacerbação do masoquismo, de vulnerabilidade e promiscuidade em suas relações, o que caracteriza aspectos da pulsão de morte: o amor se confunde ao sofrimento. Falta controle dos impulsos (transar, beber, brigar, entre outros), fatores relacionados ao prazer sem limites que poderá levar à morte (característica nos transtornos de pânico). Mostra precariedade na comunicação que estabelece com os pais, amigos e com o mundo. Em tratamento psiquiátrico, reclama da medicação prescrita e questiona a capacidade dos profissionais envolvidos. Durante as entrevistas, transfere para a análise o desejo de ser 
cuidado, exigindo que seja reforçado com freqüência sob risco de abandonar o tratamento psicológico (transfere a responsabilidade para o outro).

A persecutoriedade e destrutividade que caracterizam seu discurso durante as entrevistas são confirmadas nas narrativas do TRO. A final, foi capaz de elaborar uma história que gratificou, recuperando-se da destruição apresentada até o momento: utilizou mecanismos de defesa menos arcaicos, como a introjeção de bons objetos:

Dalai Lama: Aqui vejo uma coisa boa. Isso me remete à paz e felicidade, seres angelicais, purificação. Algo relacionado à limpeza, amor e felicidade... Remete a uma mente nova, limpa.

Apesar de predominarem as relações objetais da fase esquizoparanóide, sentiu depressivamente o conteúdo imposto pela lâmina Branca do TRO e demonstrou capacidade de restaurar / solucionar conflitos vitais.

O mesmo aconteceu com o paciente 8 (T. Misto Ansioso e Depressivo) em relação à última lâmina do teste: incomodado com a situação apresentada, retoma o conflito sugerido pelas demais e apresenta condições internas que supõe uma elaboração depressiva:

O Recomeço: Bom, vou fazer uma análise de tudo o que aconteceu até aqui. Foi tudo desagradável até um determinado momento... até o sujeito descer a escada com boa notícia (lâmina 7) e ir para casa (lâmina 12), ficar no seu aconchego. A última (Branca) seria, então, a solução de todo o problema colocado, acho que seria legal falar sobre um final feliz aqui.

Viveu com a tia paterna até os seis anos de idade, quando foi morar com o pai e esposa. Posteriormente, descobriu que sua mãe biológica vivia na prostituição. Diz que sua vida era tranquiila, com boas amizades até que, no período da adolescência, se envolveu com 
“más companhias”, fez uso de drogas (abuso) durante cinco anos (maconha e álcool, cocaína como experimentação e nega uso de outras substâncias psicoativas). Aos 18 anos de idade foi trabalhar com o pai que manifestou o desejo de ajudar o filho em relação à droga. Hoje, faz uso eventual de álcool, mas afirma descontrole em relação à bebida. "Evito beber, mas quando bebo, sigo até acabar a bebida ou o dinheiro". Enfrenta dificuldades e consequências desastrosas com a escolha feita pelo trabalho atual (escolha que, de fato, não foi sua e sim do pai), ao assumir responsabilidades que são geradoras de intenso sofrimento. Manifesta o desejo de estudar, de "realizar o sonho de ser engenheiro, uma profissão admirável”, mas rapidamente, o mecanismo de defesa de negação é acionado: "não tenho tempo para isso".

As fantasias inconscientes de morte e aniquilamento são frequentes em seu discurso e estão presentes no TRO. Associam-se ao sentimento de solidão recorrente e ambivalência na resolução de conflitos. Mostra-se angustiado quando identifica que o desejo de simbiose não é concretizado na realidade: esta percepção de que o outro inteiro existe permite o sentimento de culpa e o desejo de reparar danos causados, além de favorecer a construção de relações totais no mundo (antes parciais). Esta característica da posição depressiva é identificada tanto na entrevista clínica quanto na avaliação do TRO.

Os pacientes 7 e 9 demonstram distanciamento afetivo e aspectos dissociativos que podem comprometer o estabelecimento de relações totais. A parcialidade está presente no discurso e nas histórias do TRO. No geral, obtiveram pontuação positiva. No entanto, a parcialidade nas relações deve ser considerada durante o percurso de análise para que permita a compreensão de como lidam com aspectos internos em interação com os externos.

Paciente 7 (TEPT, T. Pânico): Histórico de perdas significativas e assaltos. Na entrevista clínica, apresenta um discurso organizado e tentativa onipotente de controle que se esvai, gerando os sintomas. Apresenta como sensações freqüentes: flashes, nebulosidade, 
dificuldade visual, tristeza intensa: "me sinto amargurado com tudo", delírios: "quando olho para o horizonte sinto que, progressivamente, tudo fica mais próximo de mim”, bruxismo, (quebrou um dente durante a noite). A tentativa de controlar onipotentemente a situação apresentada é evidente na história narrada à lâmina AG do TRO:

Memórias de um Filme: Isso me parece algo bonito e tem ligação direta com o filme 'Ghost - do Outro Lado da Vida'. É uma projeção de quando o rapaz vai embora, ele está à frente, é mais claro, e é conduzido por outras duas pessoas, só isso.

É também verificada na história da paciente 9 (T. Misto Ansioso e Depressivo) à lâmina B3, com o aparecimento de um superego arcaico que congela afetos e faz desaparecer o casal, transformado em sombra / reflexo:

A Paixão: Aqui é sombra de um casal. É só isso o que identifico, um casal que parece apaixonado, mas aqui só está refletida a sombra deles. Parece um quarto... e parece alguém observando no canto da porta, como se fosse um casal sendo observado pela mãe brava da namorada.

O distanciamento afetivo e a parcialidade são acentuados nos pacientes 7 e 9: nas entrevistas e análise do TRO, os afetos são congelados e as defesas maníacas são, frequentemente, mobilizadas devido a intensa ansiedade persecutória apresentada. A persecutoriedade impede a reparação do paciente 7 na lâmina Branca do TRO, com a manutenção do controle onipotente e projeção de objetos inanimados:

Imaginação: Nossa... A princípio é uma cartolina. Estou tentando ver algo nas quinas do papel, mas não consigo. Forçando um pouco, lembro de nuvens, num céu claro, acho que são disformes, mas vejo isso neste momento. 
A paciente 9, por sua vez, se mostra capaz de sentir depressivamente a situação apresentada na última lâmina do teste, com rebaixamento de defesas e em luto pela destruição causada (progresso para a posição depressiva):

Eu Mesma: Aqui sou eu às vezes... Posso falar de mim? Às vezes eu acho que tenho razão sobre as coisas, que sei tudo, mas sou apenas um papel em branco. Um papel onde posso escrever algo novo, uma nova história... Acho que só isso.

Os pacientes do Grupo A apresentaram condições de vislumbrarem objetos totais, com o surgimento do sentimento de depressão e abandono da fragmentação em busca da coesão reduzindo, assim, a distância entre o objeto fantasiado interno e o externo.

Apesar de algumas pontuações baixas, a análise da sequência de histórias narradas no TRO permitiu verificar que os pacientes que buscaram análise pessoal - Grupo A apresentaram a possibilidade de retificar determinadas fantasias, atingindo um processo de elaboração progressiva no decorrer do exame, com capacidade de reparação mais expressiva em relação aos demais grupos estudados.

GRUPO B - média 3,0 - 3,5 pontos no TRO e variação de 40 a 71 pontos na AGF

Os pacientes 1, 4, 5, 6, 7 e 9 apresentaram relações de objetos parciais com possibilidade de conquistarem totais, atingindo a elaboração do luto na lâmina Branca. A análise das entrevistas corroborou com os achados no TRO.

O paciente 1 (ICO - CF I), hipertenso, vem com queixa de precordialgia e dores nas pernas de forte intensidade, com melhora ao repouso e discreta dispnéia. Obtém redução dos 
sintomas com o tratamento ambulatorial, mas atribui a conquista de evolução clínica, inicialmente, ao poder de Deus, eximindo-se da responsabilidade por sua saúde.

Trabalhava com reciclagem na rua quando começou a sentir dores após acidente, ocorrido há nove anos, no qual foi atropelado por um ônibus e operado por fratura em costelas. Mesmo doente, continuou com o trabalho na rua "porque precisava seguir em frente para ter dinheiro e esperar pela aposentadoria”. Hoje, está aposentado e, há quatro meses, refere piora significativa das dores, que não sabe precisar a localização: "só Deus sabe dessa dor que eu tenho". Começa a questionar se a força que fazia no trabalho o prejudicava, porém, demonstrava angústia por desconhecer a causa: "ninguém me dizia nada, meu filho estava preocupado porque ninguém falava o que eu tinha”. No ambulatório de IC, foi diagnosticado com insuficiência coronariana e recebeu encaminhamentos necessários. Quanto ao estado de saúde atual, o paciente garante que:

Essa dor foi mandada por Deus, para eu correr antes de acontecer algo pior, porque se não fosse a dor, quando iria ao médico? É errado, o brasileiro está errado, não precisa esperar ficar doente para procurar um médico, mas é assim que acontece.

Casado há 40 anos, com cinco filhos solteiros que residem com o casal, era alcoolista e tabagista, "parei quando aconteceu o acidente”. A esposa também é aposentada, "só não é muito bom porque os filhos não ajudam, vivem nas costas da gente, eles trabalham, mas é só para eles". Após a aposentadoria, consegue reformar a casa, fazendo quartos individuais para os filhos.

Eles não me ajudaram em nada, nem uma 'palha', mobiliei todos os quartos deles, estão em quarto individual, eles não queriam ficar misturados. Meu filho de 40 anos bebe muito, ele vai morrer, eu falo: olha como eu estou doente, sem saúde, estou aqui por 
causa da pinga, você vê seu pai sofrendo e não pára de beber?! Hoje mesmo vou procurar uma clínica para a internação dele.

No decorrer da entrevista, consegue se apropriar de sua condição clínica e manifesta o desejo de melhora do filho: percebe que os comportamentos de risco do filho são semelhantes aos seus e se vê separado dele, capaz de reparar o estrago que acredita ter causado (por ser usado como exemplo, por destruir o objeto de amor). O percurso delineado pelo paciente 1 , de relações com objetos parciais para a conquista de relações com objetos totais, é observado durante a entrevista clínica e o TRO. Apesar de negar a condição atual de saúde (produto de negação da realidade psíquica), é capaz de valorizar a melhora clínica sentindo angústia depressiva diante da lâmina Branca:

Graças a Deus: Não estou vendo nada. Aqui não estou vendo nada de ruim... Posso ver que... aqui, minha saúde está limpa... É isso, estou melhor de saúde, eu posso ficar bem de novo, isso seria muito bom para mim (emocionado, chora).

O paciente 4 (IC - CF II - I), com dois IAM, DM e DCP, é ex - tabagista. Apresenta distanciamento de sua condição clínica atual, com fortes resistências em relação à prescrição de insulina, além de defesas como a clivagem e idealização. Estas defesas surgem na tentativa de proteger o ego do aniquilamento (doença). Predominam relações da posição esquizoparanóide.

Conta que, quando criança, a junta médica disse à sua mãe que morreria logo e que deveria levá-lo à Catedral para pedir ajuda com orações.

Eu tive de tudo, febre reumática, lesão no coração, minha cabeça crescia e meu corpo não acompanhava... Minha mãe me levou para a Catedral e orou para Nossa Sra. Aparecida, pedindo que, se alcançasse esta graça de me deixar viver, quando eu fizesse 
16 anos ela me levaria para Aparecida do Norte com uma vela do meu tamanho, uma fita azul e mandaria rezar uma missa para ela... Ainda estou vivo! Já fumei mais de 20 anos dois maços ao dia e fui um alcoólatra de primeiro grau... Continuo aqui.

Tem seis irmãos, uma irmã cometeu suicídio, foi encontrada em um hotel após dois dias. Um dos irmãos teve derrame cerebral e é mantido vivo com o auxílio de aparelhos. Sua mãe faleceu após IAM, há 16 anos, assim como seu pai, com IAM há 25 anos.

Paciente teve o segundo IAM há dois anos e diz: "Vaso ruim não quebra... Nem uma cervejinha eu posso? Estou brincando, sei que o primeiro gole é fatal... Tomava 3 litros de pinga direto".

A paralisação diante da situação apresentada é observada também na análise do TRO, quando atribui a responsabilidade pela vida à algo externo (lâmina C2):

Só por Deus!: Aqui é uma pessoa perto da porta saindo do quarto, tem uma cama no fundo. Ela não está contente porque está vendo alguém doente na cama. Está olhando e pensando, com a cabeça baixa... pensativo e olhando, falando com a pessoa e dizendo: 'só por Deus!', é o que eu vejo.

O paciente 5 (IC - CF II - I), hipertenso, com DPOC, ex - tabagista (parou há dois anos), há quatro anos apresenta cansaço aos esforços associado a episódios de palpitação. Ocorreu piora progressiva até que, há um ano, relatou dispnéia aos pequenos esforços, com ortopnéia. Demonstra melhora dos sintomas com tratamento clínico, no momento com dispnéia aos grandes esforços. Mostra-se disponível no exame, mas inicialmente apreensivo devido aos compromissos que teria. No decorrer da entrevista, emociona-se falando sobre questões que passa atualmente em casa, em família. Ao final, refere bem-estar por ter dividido informações. 
Casado há 20 anos, com dois filhos (19 e 21 anos de idade), e uma enteada. "O mais novo já está enrolado com uma menina, muito enrolado".

No decorrer da entrevista, retoma a afirmação anterior, dizendo que enfrenta problemas com a namorada do filho, que mora com o sogro.

Eles saíram de casa e foram morar com a família dela. Deixei as chaves de casa com meu filho, caso quisesse voltar. Sofremos muito... Ele saiu sem dizer para onde ia. Ficaram um mês fora até que ela brigou também com a família e tiveram que sair de lá, às pressas. Voltaram para minha casa e aceitei... Como não vou aceitar?... Agora dizem que 'estavam no céu e não sabiam'... A gente não quer isso para o nosso filho, a namorada tentou se matar, já aprontou várias coisas, ele sofre e nós sofremos junto.

Sente com angústia o momento relatado, fala da saída do filho como perda e necessidade de elaboração do luto, e é capaz de tolerar o estrago sofrido ao aceitar o filho de volta. O objeto amado foi introjetado de forma estável, como um todo, favorecendo as relações com o mundo exterior, com pessoas reais.

Quando soube do que ela fez (tentativa de suicídio), comecei a passar mal naquele momento, tive vertigem e desmaiei. Nem sabia que estava doente. Hoje eles estão em casa, mas fico preocupado porque a menina é desequilibrada e meu filho é um ótimo rapaz, tem muitas chances ainda na vida, sentimos muito com o que está acontecendo. A gente, que tem equilíbrio, tem que cuidar dos filhos... Família é assim, não posso abandonar meu filho, temos que cuidar.

A paciente 9 (ICO - CF II), também apresenta recursos internos para enfrentamento da condição atual de saúde e das perdas sofridas. Teve 6 filhos. Desenvolveu DM e HAS. Começou a fazer tratamento cardiológico e psiquiátrico, devido aos sintomas de depressão. Depois do nascimento do terceiro filho, paciente teve um AVC. Aos 18 anos de idade, o filho 
mais novo faleceu (há quatro anos): viajou para o litoral e escorregou em cachoeira enquanto tirava fotos do local. A paciente foi informada do ocorrido pelo telefone pela filha, acometida por doença degenerativa. Refere que sua reação ao saber da morte do filho foi de paralisação. A paciente apresentou IAM há três anos.

Há dois anos, seu filho mais velho faleceu: começou a fazer abuso de álcool após a morte do irmão caçula. A mãe tentava orientar o filho, mas ele dizia: “mãe, não posso morrer, senão você não aguentará perder outro filho”. Foi internado na UTI com alucinações e delírios e faleceu por crise de abstinência, tinha HAS. Os sintomas de depressão permanecem, a paciente segue em acompanhamento psiquiátrico e aguarda vaga para tratamento psicológico. Tem histórico de cinco perdas recente significativas: marido enfartou há 6 anos, seguido pelo filho mais novo que faleceu durante a viagem. A mãe da paciente, com DCV, faleceu há três anos. O irmão, que soube da morte da mãe, falece dois meses depois (parou de comer, faleceu na internação). Residia com cunhada desde o casamento, "ela era uma irmã para mim", faleceu no último ano, além da perda do filho mais velho, com abstinência.

Relata falta de ar e enxaqueca constante, refere não conseguir chorar diante da família. Considera-se, no momento, "anestesiada" e demonstra necessidade de reparação maníaca:

Às vezes tenho vontade... é como se não tivesse... Na minha época de casada tinha uma família, mas errei muito na vida, acho que eu podia ter feito mais coisas para acertar, errar menos. Hoje consigo sair de casa, mas tenho medo, insegurança, tenho medo das coisas que acontecem em volta de mim.

Sente depressivamente as situações (perdas) em sua vida, com afeto congruente à condição (real) apresentada e com predomínio de relações totais. Esta capacidade de reparação e os sentimentos ligados à perda e elaboração do luto são identificados tanto nas entrevistas quanto na análise do TRO. 
É possível identificar nos pacientes 5 e 9, a partir do conteúdo manifesto das entrevistas, a relação entre o aparecimento dos sintomas e os conflitos familiares e perdas sofridas. Demonstram a necessidade de proteção do aniquilamento também ao longo do TRO, atingindo a elaboração depressiva com a compreensão da condição clínica atual e podendo estabelecer relações com objetos totais.

O paciente 3 (IC - CF II), com sintomas de Cirrose Hepática e MCP dilatada, apresentou possibilidade de atingir um processo de reparação e recomeço porém, mantém o predomínio de relações objetais da fase esquizoparanóide.

Em seu trabalho como chefe de segurança,

via gente morta, muitos óbitos, pessoas doentes, você não sente, não é com você, mas quando você está passando pelo problema é horrível, fiquei sensivel a tudo isso, o que era rotineiro não era mais e começou a pesar, pensava que por mais que eu seja frio e não sinta, essa é a realidade.

Distanciamento afetivo identificado no discurso, que se apresenta organizado, intelectualizado, explicativo, além de sintomas de ansiedade importantes e mecanismo negação. Atribui à origem de seu sofrimento psíquico aos problemas enfrentados com a medicação e à impossibilidade de se expressar, falar.

A medicação que o doente necessita não é o comprimido, a injeção ou o soro, muitas vezes ele precisa falar, ser ouvido, como já aconteceu comigo: saía andando pelos corredores do hospital, muitas vezes para conversar com alguém... Dali dois dias via a pessoa saindo de alta porque melhorou. Hoje não, as instituições são depósitos de gente, não há uma viva alma que páre para conversar com você, porque não há tempo para isso. 
Pontuações baixas no TRO corroboram com análise das entrevistas dos pacientes 2, 8 e 10 que apresentaram, com maior frequência, relações simbióticas e desejos inconscientes de fusão com o objeto. Defesas da fase mais arcaica do desenvolvimento (viscocárica) foram identificadas.

A paciente 8 (HAS - CF I) refere intenso mal estar quando esteve em consulta pela primeira vez: "sentia muita agonia, tontura, dores nas pernas, estômago e coluna".

Vive um período de perdas recentes. Sofre com a perda do filho caçula, há cinco anos, e do mais velho, há sete meses (com IAM).

Inicia um choro intenso. "Eu estou perdida. É por isso que me atacou o coração, senti muito a perda deles, senti mais a morte do primeiro. Isso é muito doído para uma mãe, meu sofrimento é grande, assim comecei a sofrer do coração”.

Relaciona o sofrimento psíquico ao aparecimento dos sintomas físicos. A angústia é congruente à situação apresentada. A análise do TRO mostra sua dificuldade na elaboração do processo de luto com o aparecimento de defesas maníacas, como negação e controle onipotente. Na história narrada à lâmina $\mathrm{C} 2$, ignora o personagem acamado e não sente depressivamente a situação de perda / doença apresentada: "Meu genro: Acho que aqui é um jardim, é o que parece. Tem alguém aqui, parece meu genro. Acho que está em pé, na porta, olhando e pensando. Parece que ele está assim... alegre”.

O mesmo predomínio de relações de objeto parciais é verificado na entrevista clínica e análise do TRO da paciente 10 (IC - CF II). Apresenta MCP por QT (quimioterapia), HAS e DM. Na lâmina B3, há negação da situação triangular apresentada. A identificação do tipo triangular de relação objetal (Édipo) é necessária à formação de ego e superego: quando ignorada, dá lugar à fusão e à relação simbiótica com o objeto: "Pediatra: Aqui é um homem e 
um bebezinho? Acho que aqui é um quarto, um hospital. Está falando com o bebê. Acho que ele é médico".

O momento da separação (lâmina Branca) é vivenciado com ansiedade nos pacientes 7 e 8: foi possível verificar a qualidade do vínculo estabelecido (relação transferencial de dependência) e identificar conquistas divergentes a partir da situação de encerramento. A paciente 8 tenta controlar onipotentemente o conteúdo mobilizado e nega sofrimento, evita o contato com a ansiedade afirmando estar "muito feliz": "Jesus que te Abençoe: Eu aqui... o que vejo... Só sei que fiquei muito feliz por conversar com você. Estou muito feliz por dar essa palestra para você".

O paciente 7 (IC - CF II com DM, HAS, DCP e dois eventos de IAM - ex-tabagista), apesar de estabelecer relação transferencial de dependência, consegue elaborar depressivamente o conteúdo mobilizado pela lâmina Branca e reconhece o sofrimento diante de sua condição doença, fator necessário para aceitar ajuda e seguir com o tratamento:

A Médica Amiga: Aqui não tem nada... (pensativo) O que eu posso imaginar aqui? Esse é o começo... Já que o começo é esse, posso imaginar que estou na frente de uma médica que está tentando me ajudar de alguma forma porque não estou bem e, neste caso, estou muito contente e feliz por conversar e receber ajuda, fico mais tranqüilo.

Pontuações baixas no TRO somadas à análise das entrevistas clínicas permitiram verificar que os pacientes do Grupo B, portadores de IC CF I ou II, apresentaram desejos inconscientes, medos / ansiedades e mecanismos de defesa pertencentes, predominantemente, à fase esquizoparanóide do desenvolvimento. Alguns oscilam entre a possibilidade de retificar determinadas fantasias, atingindo um processo de elaboração progressiva, enquanto outros permanecem nas relações de objeto parciais, caracterizadas por simbiose, ambigüidade e fusão de objetos bons e ruins. 
GRUPO C - média 2,5 pontos no TRO e variação de 33 a 59 pontos na AGF

Os pacientes 5, 8 e 10 apresentaram relações de objetos predominantemente parciais e atingiram pontuações inferiores a 2,0 no TRO com avaliação de Eixo V (AGF) variando de 33 a 38 pontos. Foram freqüentes os desejos inconscientes, medos / ansiedades e mecanismos de defesa da fase arcaica do desenvolvimento (viscocárica). A análise das entrevistas corroborou com os achados no TRO.

O paciente 5 (IC - CF III), com dispnéia progressiva nos últimos dias e taquicárdico, é diagnosticado com IC Congestiva. Traz histórico de sintomas depressivos (perdas importantes - luto). Relata melhora respiratória após internação. "Fiquei agoniado, não conseguia respirar, nem pedir ajuda”. Estava com esposa e filha quando procurou o PS. Alcoolista, há 15 anos abstinente. "Talvez o álcool tenha me prejudicado em minha saúde, talvez até o problema que tenho hoje seja disso”. Conta que foi acometido pelos mesmos sintomas há oito anos, sentiu dores no peito enquanto trabalhava. "Fiquei sufocado, sem ar". Na época, era funcionário de empresa química e foi transferido para o sul do país, deixando a família em São Paulo. O paciente os visitava uma vez ao mês ou em feriados. "Tenho pouco estudo, tive que ir com a empresa”. É casado, com duas filhas. Em relação às filhas, diz:

Ela dá muita dor de cabeça, de três anos para cá não me obedece mais, não tem hora para nada. Sou pai e quero saber onde ela está... E se acontece alguma coisa na rua, passeando? Se em casa já acontece, imagine na rua. Minha filha mais velha é bem diferente... A mais nova não veio me visitar.

Apresenta dificuldade em lidar com doença: os sintomas não foram tratados inicialmente, foram ignorados. No TRO, em A1, apresenta o personagem fragmentado, incapaz de lidar com a situação ameaçadora: 
Jardim de um Homem Pensador: Um homem com braços cruzados, as pernas não estou vendo, só tem cabeça. Aqui parece um jardim, com gramas. Ele está em pé, pensando em alguma coisa. Pensa em alguma coisa que está acontecendo, alguma coisa ruim... pela expressão dele aqui, é algo ruim. Ele está preocupado, não sei se conseguirá resolver, acho que não.

As elaborações maníacas são frequentes, como acontece diante da lâmina AG, onde o drama humano é deslocado devido ao predomínio de ansiedade persecutória: “A Praia do Pinguim: Aqui parece uma praia de pinguins. Eles querem ir para a água, e são muitos... O dia está claro, bonito, vão ficar bem aqui, na praia”. O distanciamento afetivo e negação da realidade são identificados em todo o exame, dando lugar a idealizações que atuam contra a perseguição: o objeto extremamente idealizado fica impossível de ser alcançado.

O paciente 8 (IC - CF IV), com ICC descompensada, DM e HAS, não sabe dizer o que tem, afirma passar em consultas com o cardiologista há tempos, "mas ele não fala nada para mim, só examina...”. Refere tomar muitas medicações (em tom de insatisfação):

Tomo também para o coração, então nem sei explicar tudo o que eu tomo... Pedi para o médico não dar um remédio que me tirava a fome, mas parei por minha conta, se fosse pelo médico eu ainda estava tomando, via a comida e tinha ânsia de vômito.

O sentimento de desconfiança em relação ao tratamento e à equipe aparece em outros momentos: destrói e não repara, estabelece relações negativas com predomínio de ansiedade:

Vim para SP por causa do médico, só por causa do que ele fala... Porque, às vezes ele não sabe, mas diz que minha sogra vai morrer e precisa ver os filhos (referindo-se à sogra que está internada)... Isso já aconteceu duas vezes, a gente vem pessoalmente e nada... ela ainda está viva. Bom, graças a Deus, não é?! Sabe quantos anos ela tem? 102 anos... 
São mobilizadas defesas maníacas de estrutura esquizóide: desumaniza figuras humanas e congela afetos, como acontece diante da lâmina AG do TRO:

Campo: Aqui vejo uma figura, parece uma figura de bananas, são mais de seis, tem bastante. Não sei ver direito porque está tudo escuro, mas são seis figuras. Aqui parece um jardim, apesar de não ver direito, mas parece um jardim, e esse jardim contém seis bananas. Isso aqui... acho que é um campo... É isso, colocaram as bananas no campo.

Estes estados confusionais denotam a presença de objetos bons e maus que são indiscriminados. Foram igualmente identificados na paciente 10 (IC - CF IV), com diagnóstico de IC descompensada e moléstias secundárias, como IRA, úlcera infectada em MID e IAM, que se utiliza de elaborações maníacas, distanciando-se da realidade e apresentando precários recursos para lidar com perdas (luto). A negação e distanciamento do real são observados na história da lâmina C2: "Aparecida do Norte: Aqui está cheio de folhas, a roupa está cheia de folhas. Parece um jardim. Tem um homem que não faz nada, ele fica só olhando mesmo, observas coisas, está parado”.

A ansiedade persecutória afasta a paciente do conteúdo mobilizado pela lâmina e impede o contato com a realidade da morte: um personagem é negado (o acamado) e, o outro, é desvitalizado. A condição de doença é negada, mostra-se apática em relação às lâminas, relata histórias em que os personagens estão paralisados, sem ação alguma, são apenas observadores. Pouco sabe de sua doença e se coloca aquém do problema. Nega condição física e mostra resistência importante ao falar sobre o assunto, banalizando sua condição clínica.

Sei lá o que aconteceu, senti uma dor muito forte no peito e pronto, fui deixando, não sabia o que era (ao se referir sobre os primeiros sintomas)... Depois de um tempo é que 
descobri meu IAM e fui cuidar. Passei em consulta com o cardiologista e, não desfazendo dos outros médicos, mas ele sim era bom, fazia brincadeiras, era ótimo. A primeira vez que me examinou disse: 'seu coração está batendo devagar quase parando, nem sei como a Sra. está viva ainda' (risos). Eu comecei a dar risadas, meu coração bate lento e, além de bater lento, ele pára... é desse jeito que ele faz. O Dr. fez essa brincadeira e eu achei muito engraçado, ele era ótimo (risos). Que Deus o tenha, ele já tinha idade, uns 50 anos, não deve estar vivo ainda.

Diversas vezes ao longo da entrevista, diz que seu coração está “devagar quase parando" e parece se divertir com o diagnóstico médico. Distancia-se da doença, demonstra prejuízos no autocuidado ao longo de sua vida. A ansiedade persecutória é notada ao dizer que o médico "já tinha 50 anos e não deve estar vivo". O medo do aniquilamento a paralisa, levando a elaborações maníacas. A imobilização do ego e do objeto caracteriza o mecanismo de defesa empenhado. Parece identificada com o marido morto (que faleceu com sua idade), característica do luto patológico. Apresentou os sintomas de insuficiência cardíaca após falecimento do marido.

Meu marido faleceu com a minha idade, e aconteceu exatamente como o médico falou, disse que poderia morrer conversando, brincando, rindo... e foi o que aconteceu! Não desmerecendo os outros médicos, mas aquele ele era muito bom, fiquei impressionada, foi igualzinho (risos). Só agora eu estou procurando esquecer tudo, mas até meses atrás, aquilo estava na minha cabeça sabe... Agora estou melhor, mas pensava muito nisso.

Foi encaminhada para avaliação neurológica após sintomas de vertigem e rebaixamento de consciência nos primeiros dias de internação. Retorna à enfermaria com avaliação de ausência de sequelas neurológicas. O perigo de desintegração do ego (caráter psicótico) é vivenciado pela paciente e caracteriza os medos e ansiedades da posição viscocárica: a ansiedade confusional age como alerta para o perigo da desintegração psicótica e pode ser manifestada através de sintomas de vertigem, obnubilação e enjôo. 
Os pacientes $1,4,6,7,9,11$ e 13 atingiram pontuações no TRO que variaram entre 2,0 e 2,5 pontos e a avaliação de Eixo V (AGF) variou entre 38 e 59 pontos.

O paciente 13 (IC - CF III, com diagnóstico de IC descompensada, BCP e derrame pleural), apesar da baixa pontuação no TRO, apresenta sintomas moderados e capacidade para manter relacionamentos interpessoais positivos, de acordo com a avaliação do Eixo V (59 pontos). No TRO, a baixa pontuação se deve às características de relações objetais arcaicas identificadas: desejos inconscientes de fusão com o objeto amado foram comuns nas histórias, como na que foi narrada à lâmina B3:

Encontro: Aqui tem um casal, com uma manta nas costas que cobre o corpo dos dois, estão cobertos com uma manta. Parece uma sala, tem uma porta aqui e tem outro cômodo para cá, e isso é uma manta, estão enrolados. Eu acho que está um clima amoroso.

A ansiedade confusional também foi manifestada, como em AG:

Banana Queimada: Não sei... Dá a impressão de que são bananas, mas tem umas pessoas também, e estão no mesmo lugar, estão na fumaça, naquela fumaça que falei (em A1). Estão olhando... aparentemente, estão olhando para a figura que não sei dizer se é fruta, se é gente, o que é.

A tentativa de reparação da destruição do objeto é verificada, principalmente, entre os pacientes 1,4 e 6 . A paciente $1(\mathrm{CF}-\mathrm{III})$ é internada com desconforto epigástrico acompanhado de dispnéia e sudorese. Recebe diagnóstico de IAM. Tabagista desde os 19 anos de idade, refere ter cessado o vício com a internação: 
Meu pai nunca me orientou, comecei a fumar cedo, escondido na casa de minha tia aos 19 anos. Sempre usei o cigarro como escape, mas nunca traguei porque achava que fazia mal, só soltava fumaça. Todos me questionavam, perguntavam por qual motivo não tragava, e eu dizia que era feio e tinha medo de que me prejudicasse. Com a internação, parei de fumar e parei de roncar, nem acredito que não ronco mais, tinha muita vergonha disso, meu marido me cutucava no meio da noite para que eu parasse.

A paciente, que demonstra sintomas de abstinência durante a entrevista, idealiza o momento da internação e procura controlar onipotentemente a situação vivenciada. Foram características presentes também na execução do TRO, como em BG: "Festa de Casamento: Parece que vai ter uma festa, só vejo coisas boas... estão aguardando um pessoal. Parece que é a entrada de um clube, deve ser algum casamento. Tem algumas pessoas aguardando os noivos, só isso”.

No decorrer da entrevista, a paciente parece começar a entrar em contato com os medos envolvidos no processo saúde - doença...

Sou do lar, ajudo minha família, já cuidei de meu pai, mãe, irmã, sogra e de meu irmão. De todos estes, só minha sogra está viva. Até agora, não entendi o que aconteceu comigo, porque isso aconteceu... Não imaginava que tinha colesterol alto porque não como porcarias, só às vezes... Tenho muita preocupação com meus filhos, acho que isso agravou meu problema, fico apavorada com a gravidez de risco da minha filha (emocionada), ele nascerá prematuro... fiquei imaginando ter que segurar aquela coisinha nas mãos (faz gesto com a mão), não vou conseguir... isso tudo me deixou doente...(chora) Queria pegar minha filha no colo, jamais esperava estar aqui neste momento.

No entanto, os mesmos mecanismos de defesa são ativados quando começa a sentir depressivamente a situação de internação: “... mas eu gosto de fazer porcarias para minha 
família, é uma maneira de agradar a todos (risos). E outra, estou me sentindo limpa aqui, sem o cigarro. Eu sou uma rocha, e rocha não quebra!".

Sente-se responsável pelo cuidado de todos os familiares, mas nega sua própria condição clínica. Admite que a enfermidade lhe favoreceu ao parar de fumar ou roncar, no entanto, não reconhece a necessidade de reorganização pessoal ou a demanda de cuidados especiais, uma vez que "é uma rocha e não quebrará".

No TRO, diante da lâmina Branca, mostra condições de atingir um nível menos arcaico de relações, ao desejar reparar o objeto atacado / destruído e ao sentir angústia depressiva pela perda objetal:

Festa de Arromba: Aqui estou eu e meus cinco netos, eи e meu velhinho (marido), meus filhos e meus netos... meus amigos... tenho muitos amigos, sem eles não sou ninguém... Algo novo será construído, algo melhor para todos nós. Sinto a falta deles (emocionada).

A história narrada à lâmina Branca demonstra a tentativa de reparação dos pacientes 4 e 6. O paciente 4 ( $\mathrm{CF}-\mathrm{III})$, que recebe o diagnóstico de IAM. O paciente é hipertenso, tabagista, foi internado com sintomas de aperto típico associado à náusea e sudorese. Os títulos atribuídos às lâminas (Pessoa Desesperada, Tristeza, Ir Embora, Não Entrar, Desesperado) denotam a tentativa de recuperação na última:

Sossegado: Vejo aqui uma pessoa lutando para viver, para morar... Aqui está tudo limpo... Quando a pessoa está na rua não tem onde ficar. Aqui seria um canto bom para ela ficar. Se acontecer de ficar aqui, ficará sossegado, esfriando a cabeça, poderá ter uma vida diferente.

O paciente 6 (IC CF - III) com diagnóstico de IC descompensada, foi internado com queixa de mal estar há 1 dia, relatando cansaço aos pequenos esforços acompanhado de dispnéia, com leve congestão pulmonar e hipotensão arterial: 
Antes não sentia nada, depois comecei a me ocupar só de médicos. Chegava em casa achando que estava bem, mas sempre tinha que correr, nunca estava bem, não conseguia dormir, me sentia sem ar, sufocado... Cada hora é uma coisa, fico o dia todo bem, quando chego a tarde tenho problemas, já tive durante a noite e estava sem carro, tive que correr, sem ônibus... Se não fosse minha velha (esposa) me ajudar, já estaria morto.

Refere se sentir bem em poucos momentos na vida: "Quando penso que está tudo bem, não está, é difícil, minha doença tira minha vontade de fazer as coisas".

Apresenta ansiedade e negação onipotente na entrevista e na execução do TRO, como na história narrada na lâmina AG: "Praia e Fundo do Mar: Aqui tem um monte de amigos numa praia, brincando. $O$ dia está claro e bom, alegre. Eles estão contentes, estão felizes, $e$ eu não gosto de fazer estas coisas”, referindo-se ao TRO.

A agressividade presente no exame se mostra fundamental para a manutenção da saúde. A recuperação da destruição causada e apropriação da condição clínica é identificada na história da última lâmina: "Virada na Vida: Imagino que alguma coisa pode melhorar, é isso o que posso ver aqui... Não consigo ver mais nada, está tudo branco, e isso me diz que alguma coisa ficará melhor, eu quero ficar melhor e posso".

Os pacientes 9 e 11 demonstram a manutenção de desejos inconscientes, medos / ansiedades e mecanismos de defesa arcaicos, demonstrados no TRO e entrevistas. A paciente 9 (IC CF - III), internada com diagnóstico de AVCi, relata:

Minha família é próxima, mas não tenho muitos amigos ou com vizinhos, não fico na rua conversando com ninguém, não gosto... Depois que eu tive um... Nossa, esqueço tudo o que vou falar, foge da minha cabeça, percebi isso estes dias... Eu estava com problema de chorar muito, de triste, chorava em casa... acordava cedo e chorava, não queria 
conversar, evitava as pessoas, não queria ver ninguém, chorava escondido porque meu marido não gostava de me ver chorando.

Evita o encontro com amigos e vizinhos e nega preocupações com a doença. Refere não saber identificar o motivo da tristeza. "Não queria conversa nem com a minha família, não tinha vontade de fazer nada, queria ficar em casa sozinha, quando alguém chamava me dava até tristeza só de pensar que eu tinha que conversar”.

Os aspectos de sua depressão aparecem também na história em AG, na qual o sentimento de desesperança prevalece: "Sem motivo para viver: Aqui eu não imagino nada, parecem pessoas, meio perdidas... estão no espaço, perdidas. São pessoas que não têm motivo de viver (chora)".

Inicialmente, a paciente demonstra interesse no teste, porém durante a execução, mostra-se incomodada com o conteúdo das lâminas, perde o interesse e tenho que motivá-la a terminar. Quando apresento a C2, diz: "pensei que esta fosse a última, você falou que estava acabando...”, demonstrando angústia importante que foi mobilizada a partir da BG, quando relata a história de um personagem triste devido a um intenso sentimento de solidão:

Pessoa precisando de ajuda: Parece uma casa isolada, com umas pessoas meio perdidas, é o que eu vejo: uma casa abandonada. Essa pessoa está sentindo muita tristeza, ela está muito triste... Essa pessoa está precisando de ajuda, mas está sozinha.

O distanciamento da paciente 11 (IC CF III) em relação à doença é identificado quando atribui melhora clínica ao desejo de Deus, eximindo-se desta responsabilidade: “Acho que tenho que ficar calma, confiar sempre em Deus e depois nos homens, na Medicina, porque se Deus não quiser não adianta, ele é o médico dos médicos”. 
Características de depressão que são identificadas nas entrevistas foram confirmadas nas histórias de TRO. A paciente 7 (IC CF - III), que recebe o diagnóstico de IC descompensada, DM descompensada e derrame pleural, relata a seguinte história em BG:

Tristeza: Aqui parece uma família, numa casa, juntos, conversando, é isso o que parece. Acho que estão conversando, falando sobre eles mesmos, não sei dizer o que estão sentindo. Esse da porta está muito triste e os da janela não, estão felizes, conversando. $O$ da porta está sozinho e triste (chora).

Neste momento, começa a chorar e procuro acalmá-la. A paciente diz que não sabe o que sentiu, o que pensou... "Não pensei em nada, mas de repente me deu um aperto... Não sei explicar o que aconteceu". O marido, afastado, vê a esposa chorar e se emociona. A paciente continua na Branca:

Solidão : Aqui não tem nada... nada meu Deus! Aqui não tem nada! Imagino assim um pessoal vivendo uma vida sem nada, sem ter o amor de uma pessoa, sem ter família (reinicia o choro), vejo como uma coisa ruim, uma solidão mesmo, esse é o nome mesmo, pode colocar aí.

Relações objetais parciais predominaram nos pacientes do Grupo C, porém, a presença de algumas relações de objetos totais foram identificada nas entrevistas e histórias do TRO, como demonstrado. Nos pacientes 2, 3 e 12, a avaliação no TRO variou entre 2,5 - 3,0 pontos e entre 51 e 58 pontos no Eixo V (AGF), apresentando sintomas moderados e tendência adaptativa diferenciada.

O paciente 2 (CF III), ex-tabagista, internado com dor precordial acompanhada de sudorese e dispnéia. Com bom contato na entrevista, apresenta distúrbio da dinâmica familiar, recebe visita de dois filhos e se queixa dos quatro outros que não vieram. Tem dois filhos 
criados pelo avô e raramente o visita, "nem no hospital". Emociona-se ao falar da filha e dos netos: "ela não foi ao enterro da própria mãe". Refere não acreditar que a doença seja grave e manifesta o desejo de ir para casa. Pensa que descompensou porque "acumulou muita coisa, muita tristeza”. Intenso sentimento de solidão e abandono e histórico de falhas no autocuidado. Incongruência quanto ao afeto apresentado em relação ao seu estado de saúde geral, com certo distanciamento afetivo. Em C2 (TRO), admite personagem acamado e é mobilizada a angústia depressiva, indicando capacidade em aceitar ajuda, sentir a perda e elaborar o luto:

Procurando Socorrer uma Vida: No fundo tem uma cama (pensativo). Aqui parece ser uma enfermeira... Tem uma pessoa que vai entrar, mas não sei se é um médico ou enfermeiro, mas é um homem. Ele entra e dá socorro para a pessoa que esta na cama, precisando de ajuda.

O mesmo pode ser reconhecido nas histórias e conteúdo da entrevista do paciente 3 (IC CF - III), que devido ao IAM, foi impedido de seguir com o trabalho exaustivo:

Sempre quis que meu trabalho fosse perfeito, as pessoas gostam do meu serviço e nunca faltou oportunidade, mas homem é teimoso, continuei trabalhando, pegando peso, difícil viu... Confesso que sou um prato cheio para brigar porque já tive muitas decepções na vida.

Faz o "balanço" de sua vida na última lâmina do TRO, com possibilidade de atingir uma elaboração depressiva, consegue admitir o sofrimento imbricado no processo e aceitar tratamento:

Minha Vida Hoje: Bem, juntando tudo o que falamos, o que mais me chama a atenção ainda é a figura anterior (C2)... Mas, vou criar minha imagem aqui: vivi minha vida assim, num mundo obscuro, sempre com medo de tomar uma decisão, sempre vivi 
sozinho no meu mundo aqui dentro, não queria dividir nada com ninguém. Mas, chega uma hora em que você tem que tomar uma decisão... chega uma hora que você pára porque a própria vida te coloca uma parede na frente e você tem que sair, tem que resolver, tem que aparecer. É aquela coisa... o cara para receber o troféu tem que correr e chegar em primeiro lugar, senão não recebe. Ninguém gosta de ser o segundo, mas nem sempre você pode ser o primeiro, não é sempre que você ganha, então tem que estar preparado para ganhar ou perder, foi aí que resolvi tomar uma decisão. Via as pessoas, elas não me machucavam, mas eu machucava as pessoas no meu modo de pensar... então, comecei a me achegar mais às pessoas. É aquela coisa, quando você consegue se aproximar daquilo que tem medo, começa a encontrar resultado, então são novidades que aparecem e que mostram que não é nada daquilo que você imaginava. Essa é minha vida hoje, me vejo dessa maneira. Vejo que eu era uma pessoa sem rumo, tinha medo de me entrosar, hoje não tenho mais esse medo, se tivesse cinco ou seis pessoas perto, já me dava uma coisa... Hoje não... fui saindo para a vida aos poucos, ninguém chega ao topo se não subir um degrau de cada vez, penso que é assim que estou fazendo.

Pontuações do TRO somadas à análise das entrevistas clínicas permitiram verificar que os pacientes do Grupo C, portadores de IC CF III ou IV, apresentaram desejos inconscientes, medos / ansiedades e mecanismos de defesa pertencentes, predominantemente, à fase esquizoparanóide do desenvolvimento, com frequência significativa de características da posição viscocárica. A maioria estabelece relações de objeto parciais e apresenta recursos limitados para a conquista de relações objetais totais.

GRUPO D - média 2,5 pontos no TRO e variação de 30 a 60 pontos na AGF

As pacientes 1 e 2 apresentaram relações de objetos parciais, com características da fase viscocárica, atingindo pontuações inferiores a 1,5 no TRO com avaliação de Eixo V (AGF) de 30 e 35 pontos, respectivamente. A análise das entrevistas corroborou com os achados no TRO. 
No TRO, a paciente 1 (IC CF - IV), manifesta intenso sentimento de solidão e a confusão é evidente, como em A1 (insegurança ao afirmar que viu água) e BG, onde ignora o personagem manifestando a negação da realidade psíquica: "Febem: Nossa! Pode ser uma febem, um lugar que cuida de crianças carentes, só isso”.

O desejo inconsciente de simbiose e dependência do objeto amado é frequente. A desintegração do ego é verificada em B3, quando ignora o terceiro da relação:

A Igreja: Esse aqui é o pai, carregando o filho, ou aquele é o Santo Antônio, porque ele carrega o filho. Está no santuário, dentro da Igreja, estão chorando. O nome da história vai ser bem difícil...

A fantasia de simbiose é contestada na realidade, quando o marido a abandona (comportamento freqüente). Durante a entrevista, relata um dos momentos em que o marido tenta retornar, mas é impedido pela paciente:

Quando ele volta, quer gastar o pouco dinheiro que temos com bebida. Ele é agressivo com palavras, diz sempre que, se eu estou realmente doente, deveria morrer logo! Quando está desempregado fica bonzinho, mas é só arrumar emprego que volta com a bebida. Mesmo sabendo que eu estava ruim, não me mandou nada do interior. Quando volta para casa, passa mais tempo fora do que dentro, fica no barzinho, no forró, volta só no outro dia. A verdade é que, quando ele foi embora, fiquei mais tranqüila porque não passava tanto nervoso. Preciso de repouso até esta fase passar. Sempre fala que sou uma pessoa que está morrendo e que não morre, que prefere ficar longe ao ter que ver minha cara inchada todos os dias.

Estruturas esquizóides (desumanização de personagens) são observadas, dificuldade diante do tema de doença e morte leva à utilização de defesas maníacas na tentativa de lidar com os aspectos internos. A dor e sofrimento dão lugar à desesperança e desamparo. 
A paciente 2 (IC CF - IV) se utiliza frequentemente de defesas maníacas ao longo da entrevista e do TRO. A ansiedade persecutória acentua a negação da condição clínica: "Quem sabe com um tratamento eu melhore, vou tomar os medicamentos, quem sabe eu nem precise de um transplante”. O mecanismo de identificação adesiva como negação onipotente da realidade é observado nas histórias referentes às lâminas AG: "Meditação: Aqui já vejo seis pessoas, três em pé e três sentadas. Pela foto estão meditando. É uma paisagem branca, não tenho muito o que falar" e Branca, quando ignora a possibilidade de reparação com a narrativa de uma paisagem que não a inclui, segue desvitalizada: “A Praia: Vejo uma coisa neutra aqui, não tem nada. Mas adoro paisagens, se é para imaginar alguma coisa, vejo montanhas, com mar, sol, folhas de coqueiro".

O mundo interno caótico das pacientes do Grupo 4 é vislumbrado nas entrevistas e histórias do TRO. O desejo de fusão ou fantasia de simbiose aparecem em todas as pacientes deste grupo. A ansiedade é frequente nas histórias, repletas de aspectos arcaicos da mente. As pacientes 1 e 2 são consideradas as mais graves neste grupo. Em seguida, estão as pacientes 4 e 5 e, posteriormente, 3, 6 e 7, que apresentam melhores condições de estabelecerem relações menos parciais. A paciente 3 demonstra ser capaz de sentir a perda e atingir a elaboração do luto ao final do exame.

A paciente 3 (IC CF - IV), inicialmente, relata os sintomas gerados pela IC manifestando o desejo de abandonar o tratamento, negando a realidade de sua condição clínica. A ansiedade persecutória é verificada na história narrada diante da lâmina AG:

A Viagem: Nossa! Se eu for dizer o que to pensando aqui agora... Você já assistiu a novela 'A Viagem'? Então, aqui é um céu com um pasto muito bonito, um monte de gente flutuando. É bem igual a novela. A minha filha me disse que vou pôr você em parafuso (risos). 
A realidade da morte é negada e controla onipotentemente o conteúdo da lâmina. A história de espíritos em um "pasto bonito" a impede de sentir depressivamente o que foi mobilizado. Reações maníacas são identificadas nas histórias e na análise da entrevista, quando diz:

Às vezes fico nervosa, cansada, fico irritada. Ontem fiquei de cara feia com o pessoal em casa porque, se me sinto bem, quero largar tudo, todo o tratamento, continuar como estou e eles ficam bravos comigo... Mas sei que se eu tiver uma recaída será pior. Será que não mereço ficar quieta no meu canto e parar com tudo?

Sentiu que havia espaço para falar do que realmente lhe atemorizava, o medo da morte. Com o rebaixamento das defesas, relata que já tinha sido "desenganada" pelos médicos, mas que continuava viva esperando por um desfecho diferente, o que demonstrou recursos internos diferenciados que dispunha para tolerar a espera. Consegue, então, atingir uma elaboração depressiva na última lâmina do TRO:

Rio das Águas Brancas: Um rio com muitas pedras, árvores, água corrente, meu marido e meus filhos brincando na água comigo, lógico (risos). Um céu muito azul e nuvens muito lindas, parecem algodão. Esse é meu quadro, é assim que gostaria de estar (emocionada, relembra local que freqüentava, há anos, em família).

Dispondo de um ego mais integrado, são identificadas condições internas para tolerar o processo saúde - doença com a tentativa de reparação do estrago inicial. Sente depressivamente o conteúdo mobilizado e é capaz de elaborar o luto pela perda da integridade física, aspectos necessários para a compreensão do diagnóstico e adesão ao tratamento.

A paciente 7 (IC CF - IV), apesar da pontuação inferior em relação à paciente 3, sente depressivamente a lâmina Branca e manifesta possibilidade de sentir a perda do objeto. 
Nos grupos C e D, as relações objetais da fase viscocárica do desenvolvimento foram mais frequentes, como mostrou o STID (Rosa, 2005) nos grupos estudados (tabela 8).

\section{- Das Fantasias Inconscientes...}

As fantasias foram consideradas como representantes do conteúdo particular dos impulsos, que dominam a mente em determinado momento e, como explicita Isaacs (1952), as que são repetidas no mundo adulto correspondem àquelas que se manifestaram em situações anteriores.

A DCV pode gerar uma situação regressiva, principalmente nos pacientes graves, nos quais foram identificadas fantasias inconscientes predominantemente de fases arcaicas do desenvolvimento. Portanto, os mecanismos defensivos arcaicos dos quais se utilizaram são produtos da conexão entre as fantasias e a estrutura mental, como afirma Segal (1982).

Fantasias inconscientes de morte são verificadas em todos os grupos.

No grupo $\mathrm{D}$, as fantasias inconscientes de retaliação e mutilação estão ligadas à cirurgia de enxerto e foram identificadas tanto na análise das entrevistas quanto nas histórias do TRO. A paciente 3 diz:

Olha, eu logo imaginei que precisasse de um transplante, mas é uma coisa que funde nossa cabeça. Se parar para pensar direitinho, o transplante não é uma coisa normal. Tirar uma coisa de dentro de você, que vai para estudo ou para o lixo porque não presta mais... como diz minha filha, não é normal. Penso que vão tirar uma coisa sua para colocar um coração que não é seu, é de uma outra pessoa, como vão costurar as artérias?

E continua:

Imagine só, eles (os médicos) tem que costurar todas as artérias, as veias, todas as coisas. Tenho muito medo, não quero passar por fases de complicações, morro de medo 
de ser entubada, pelo amor de Deus! Não quero esses negócios de rejeição. Se não for assim vou me apavorar, ou não, ou nem vou perceber porque estarei numa cama. Se for para passar mal depois, prefiro tomar remédio e ficar assim. Sei que não colocarão na mesa alguém com $30 \%$ de ter complicações e tenho que fazer enquanto meu coração ainda está funcionando, se ficar fraco, esquece.

A paciente 4, que parece assustada diante da lâmina AG, narra:

Perdido no Pensamento: É... um homem com uma cara tão fechada, cabelo grande, sobrancelha grande, lábios grossos. Está olhando para o tempo, com o pensamento bem longe. Nossa!

Fantasias de mutilação foram identificadas nas pacientes do grupo D: 1, 2, 4, 6 e 7, durante a entrevista ou na execução do TRO. O sofrimento psíquico na situação de espera pelo TC provoca fantasias ligadas ao órgão e à morte como desaparecimento do self, que foram frequentes neste grupo. A paciente 5 diz:

Eu queria te contar sobre um sonho que tive... Nele, saía no portão de minha casa e tinha um cemitério em frente. Minha filha estava deitada na cova e falava para mim: 'Vem, mamãe, vem dormir aqui, traz o travesseiro e vem comigo'. Acordei assustada, olhei para ela e estava bem, meu coração disparou. Será que meu coração vai agüentar até chegar um doador?

A paciente 6 se utiliza de mecanismos de negação e escotomização no início da entrevista, conta que a irmã...

... sempre fala que minha doença está na minha cabeça, mas como é isso? Se eu já morri tantas vezes... Já levei muitos choques, morria e voltava, como meu problema de coração é imaginação? Quando sofri uma parada cardíaca, eu falava por dentro, aqui (aponta 
para sua cabeça), porque aqui (apontando para a boca) não saía nada. Acho que não preciso de um psiquiatra. Deus que me perdoe, mas ela tem inveja da minha doença.

A partir da submissão ao TRO, o discurso sofre alterações significativas: o discurso repleto de mecanismos defensivos arcaicos é descartado e a paciente entra em contato com a sua dor e fala de seu sofrimento, relatando episódios de profunda dor, solidão e desamparo:

Gostei demais das figuras que mostrou, era como se eu pudesse me ver nelas, ver minha vida ali... Na semana passada, quando estava lá, parada, com a minha dor no peito, me vi sozinha, não conseguia me mexer, comecei a rezar. Como sou católica, pedi a Deus para me levar logo, para que minha dor passasse, e nós conversamos... Disse ele que já havia perdoado quem tinha me feito alguma maldade, perdoei minha irmã, meu marido que me deixou, mas quero que minha filha tenha uma vida mais feliz antes de eu morrer.

Fantasias de fragmentação e aniquilamento aparecem nos discursos caracterizados, particularmente nestes grupos, pela desesperança.

\section{- Dos Aspectos Psicossomáticos...}

Considerando como aspectos psicossomáticos o comprometimento no processo de simbolização refletido na patologia apresentada, o material da entrevista revelou os processos psíquicos envolvidos na condição clínica de cada paciente. A interação entre o sofrimento psíquico e as manifestações orgânicas foi identificada na avaliação psicodinâmica proposta no presente estudo e ponderada na apreciação de todos os pacientes. A pulsão de morte (descontrole) de acordo com Marty e Muzan (1983) pode ser responsável pela desorganização psíquica encontrada nos casos onde são identificados fenômenos psicossomáticos.

Como ilustração, temos: 
No grupo A, o paciente 1 sofreu a perda narcísica: o olhar da mãe não devolveu a imagem projetada, não favoreceu a criação de um reflexo. O paciente parece incapaz de pensar porque não pode refletir e, quando olha no espelho, não identifica a própria imagem, não se reconhece. Este seria um impedimento para o processo de simbolização, manifestado através da falta controle dos impulsos (beber, brigar, comer). $\mathrm{O}$ paciente 8 apresenta descontrole (impulsividade) semelhante, ao relatar situações de brigas no trânsito, sintomas de pânico no trabalho ou excesso de álcool (abuso) que o impedem de concluir tarefas, finalizar projetos e cursos de interesse. O discurso, por vezes difuso (queixa diluída), não impede a qualidade do contato: acredita precisar de ajuda, mas admite "não saber exatamente em que aspecto pode ser ajudado”.

No grupo B, o paciente 4 relata: “Meu filho foi embora sem explicação, voltou depois como se nada tivesse acontecido, senti sua falta" e a paciente 9 diz que...

...as discussões em casa são freqüentes, quando acontecem, sinto minhas mãos trêmulas e meu braço dormente. Não consigo me comunicar com minhas filhas, só sinto, som falo com meus netos, parece que são mais maduros e entendem, é como se tentassem me proteger.

Demonstra a dor vinculada aos conflitos familiares. E continua:

Minha filha é deprimida devido aos problemas e limitações da doença degenerativa, sempre chora e chama pelo irmão (que faleceu durante viagem)... Briga comigo por não se conformar com a perda, diz que eu deveria sentir como ela sente... mas não sabe como me sinto... Grita e me culpa por não me expressar como ela faz.

A paciente 8 (Grupo B) precisa ser reorientada quanto à importância da medicação. Encontra-se em processo de luto, sofre a perda dos filhos, uma delas recente (há sete meses). 
A queixa física é relacionada ao sofrimento vivido, "meu coração parecia que não agüentaria” e, neste momento, pôde verbalizar os sintomas, diminuindo as defesas e traduzindo o sofrimento em palavras.

Esta é a importância de encontrarem um espaço para falar de uma outra dor, que não a física. Ainda no grupo B, o paciente 3 afirma: "hoje ninguém encontra esse espaço, o espaço para falar das suas coisas”. O paciente 5 conta que foi acometido pelos mesmos sintomas (dispnéia, cansaço, precordialgia) há oito anos, quando foi transferido para empresa no sul do país, "como tenho pouco estudo, tive que ir com a empresa. Na época, parecia que não conseguia respirar direito... Só podia ver minha família uma vez por mês, às vezes, nem isso".

Seguindo com as ilustrações, no grupo C o paciente 12 nega preocupação com a saúde e racionaliza o discurso. Apresenta importante distanciamento afetivo e preocupações com o resultado desta avaliação. O sofrimento é caracterizado por queixas frequentes referentes aos atendimentos que recebeu em consultas ou internações hospitalares, hostilizando os profissionais da equipe. McDougall (1991) afirma que este seria um modo de defesa arcaico, quando a somatização está vinculada à economia do afeto, sendo que este "agir arcaico" se dá por uma descarga direta para expulsar do psiquismo e deslocar para o corpo os afetos que são insuportáveis.

O que é latente no discurso foi possível se tornar manifesto a partir do TRO, da análise das histórias somadas à entrevista, considerando os aspectos subjetivos envolvidos na condição clínica. A postura descrita permite a compreensão dos aspectos psicodinâmicos e identificação das manifestações psicossomáticas nos diferentes grupos, corroborando com o conceito empregado nesta investigação, no qual a psicossomática se caracteriza como atitude na promoção de saúde, postulando uma visão integrada da unidade corpo - mente, 
considerando o paciente inserido em um ambiente específico. A somatização é considerada, de acordo com Rodrigues e Campos (2005), a resposta fisiológica que traduz a expressão das emoções.

A compreensão do conteúdo real da fala fez parte do processo diagnóstico, demandando atenção àquilo que não foi verbalizado. A análise da transferência foi importante recurso para atingir esta compreensão. Esta seria uma das contribuições da Psicanálise no campo médico, o de estudar as relações de objeto a partir do modelo transferencial contratransferencial a fim de esclarecer o que é obscuro no discurso, como afirma Eksterman (1978).

Pacientes que apresentaram boa capacidade de simbolização, criando histórias com início, meio e fim, foram capazes de reconhecer os aspectos sugeridos pela lâmina e elaborar o conflito com a apresentação de medos / ansiedades, mecanismos de defesa e desejos inconscientes que representaram um ego mais organizado, o que foi identificado, principalmente, entre os pacientes: 2, 3, 5 e 10 (Grupo A); 4, 5, 6 e 9 (Grupo B); 2 (Grupo C); 3 e 7 (Grupo D). Os pacientes relatados demonstraram melhores condições de simbolização em relação aos demais, o que foi confirmado com a análise da entrevista clínica e do TRO: apresentaram recursos internos de reparação, com relações de objetos totais e tendência adaptativa. Conflitos familiares foram identificados, muitas vezes, como "situação gatilho" para a sintomatologia apresentada.

A capacidade de expressão / simbolização é mais comprometida nos pacientes dos grupos $\mathrm{C}$ e $\mathrm{D}$, corroborando com as baixas pontuações apresentadas tanto no TRO quanto na AGF. O prejuízo no processo de simbolizar é produto de um ego menos integrado, de um funcionamento psíquico primitivo que ativa mecanismos arcaicos de funcionamento, de modo 
que as tensões físicas, de acordo com Silva e Caldeira (1992), não encontram vias para expressão no campo psíquico e permanecem no físico.

No entanto, o comprometimento no processo de simbolização pode ser verificado diante de situações específicas como, em muitos casos, ocorreu frente à lâmina C2.

Observou-se que a lâmina C2 desempenhou papel específico para os pacientes cardiopatas.

No TRO, é verificada uma evolução do paciente durante a execução do teste: as defesas diminuem ao longo da apresentação das lâminas e é possível atingir o processo de luto e elaboração da perda na última (Branca), o que demonstra a capacidade de reparação do indivíduo, segundo Phillipson (1981), Ocampo (1981) e Rosa (2005).

A lâmina C2 sugere um estímulo que implica em tolerar a morte ou a doença do objeto, induzindo ao aparecimento de fantasias reparatórias ou destrutivas que levam a elaboração depressiva ou maníaca. A avaliação mostrou que é possível que, para os pacientes cardiopatas, a apresentação da lâmina C2 seja responsável por uma ruptura no processo de evolução. Esta ruptura foi identificada em pacientes de todos os grupos. Porém, entre os cardiopatas, especialmente os mais graves houve, a partir deste momento, dificuldade expressiva de lançarem mão de objetos internos reparadores para atingirem elaboração depressiva na lâmina seguinte (Branca): a partir da C2, os pacientes mais graves mantiveram atitudes regressivas e demonstraram aspectos de um ego cindido que não foi capaz de sentir depressivamente o conteúdo apresentado; reagiram maniacamente e manifestaram características de fases arcaicas do desenvolvimento, que se prolongaram até o final do exame.

Em algumas doenças a correlação entre os aspectos emocionais, situações de vida e patologia somática é mais evidente. Assim, se toda doença é considerada psicossomática, 
significa que existe um ser provido de soma e psique inseparáveis, anatômica e funcionalmente, como afirma Mello - Filho (1992).

\section{- Dos Fatores de Risco...}

Foram considerados FR aqueles componentes que agem como um fator adicional, agravando a condição clínica na DCV. Relações objetais e fantasias inconscientes extremamente arcaicas podem determinar FR na DCV, FR psicossociais que aumentam a predisposição para eventos cardíacos, como afirmam Rozanski (1999) e Avezum (2004). São eles:

- Sentimentos de desesperança verificados principalmente entre os grupos mais graves;

- Prejuízos no autocuidado e desconhecimento da doença;

- Resistências em seguir prescrições e orientações da equipe;

- Comorbidades de ordem psicológica / psiquiátrica, como a depressão, que pode ser o principal fator de aumento do risco de morte no ano seguinte ao IAM (Petersom, et al., 1996; Frasure - Smith, et al., 1995; Brandwin, et al., 2000; May, et al., 2009; Margoto, et al., 2009; Rossi Neto, 2004), e o estresse (Ballone, 2007; Jiang, et al., 1996),

- Abandono do tratamento (negação da doença).

Ilustrando, no grupo B:

O paciente 1 apresenta falhas no autocuidado quando afirma que sua dor atual " $f o i$ mandada por Deus, senão não iria ao médico”, sendo que, há nove anos, sofre com as dores que o impedem a realizar atividades rotineiras e que não foram diagnosticadas. $\mathrm{O}$ mecanismo de negação esteve presente em todo o exame. Na entrevista, segue dizendo que "está ótimo, $e$ 
é graças a Deus”, o exime da responsabilidade do autocuidado, necessário em sua condição clínica. Demonstra compreender as falhas ao garantir que "não precisava ficar tão doente para procurar um médico”, porém apresenta precários recursos para a manutenção da saúde.

Acompanho a consulta médica do paciente 4 e, no início da entrevista clínica, aponto para a reação demonstrada em consulta ao receber prescrição de insulina. O paciente confirma o incômodo, diz não entender a orientação. "A Sra. viu como fiquei assustado, não é?". Admito e solicito que fale sobre o incômodo, quando afirma que gosta de comer carne e pernil no fim do ano e demonstra titubear quanto ao seguimento das orientações do médico: "a insulina vai me atrapalhar, quero comer no fim de ano e sem insulina é melhor”. Questiono uso de bebida alcoólica atualmente, fica reticente e depois diz que não faz ingestão de bebida alcoólica. Foi alcoolista durante 20 anos. Ao receber a notícia de prescrição de insulina, o paciente paralisa, nega condição e rejeita orientação inicial. Investigo histórico de abandono no autocuidado: apesar de se abandonar em alguns momentos, em outros identifico preservação à vida e procuro reforçar sua capacidade de proteção para não renunciar ao tratamento sugerido.

Durante a consulta médica no ambulatório de IC, a neta da paciente 8 afirma que a avó é "esperta e lembrava sempre de tudo, inclusive da medicação", porém, a paciente diz durante a entrevista que, hoje, esqueceu de tomar os remédios da manhã. Aponto para esta falha e a paciente diz que não queria mentir e que, como vai muitas vezes ao banheiro quando toma o remédio, preferiu esperar para tomar na volta. Mostro que, então, foi uma escolha em não tomar a medicação e não um esquecimento e que esta escolha implicaria na não manutenção de sua saúde.

A paciente 5 apresenta sintomas que não foram tratados inicialmente, demonstrando prejuízos no autocuidado que agravaram a condição clínica atual. 
No grupo $\mathrm{C}$, a paciente 1 se responsabiliza pelo cuidado de todos os familiares, mas nega sua própria condição clínica. Admite que a enfermidade lhe favoreceu ao parar de fumar ou roncar, no entanto, não reconhece a necessidade de reorganização pessoal ou a demanda de cuidados especiais, uma vez que admite ser "uma rocha, e rocha não quebra”. O paciente 2 se mostra, inicialmente, capaz de suportar a doença, porém no exame, se apresenta inseguro e poliqueixoso, sob suspeita de que não seguirá recomendações médicas e que precisará de suporte familiar.

O paciente 3 negou por anos sua condição de saúde fragilizada, atribuindo o mal estar ao "calor intenso". Em luto por perder uma condição necessária para o trabalho, utiliza defesas importantes com sintomas de agressividade associada à fobia social, verificadas tanto no discurso quanto na análise das lâminas do TRO. Esconde-se da doença, o que chama de “lado obscuro", negando a condição clínica. No entanto, tem consciência de que "chega uma hora que tem que sair da escuridão, aparecer e tomar uma decisão porque a vida lhe coloca uma parede à frente para atravessar”.

A paciente 4 nega a realidade (perigo da doença), desconhecendo os fatores que agravam sua condição atual. Apresenta profunda tristeza, aflito em relação ao trabalho, angústia diante da possibilidade de morrer, "como minha mãe que faleceu cedo, ou meu filho" e deseja encontrar um "refúgio" para "esfriar a cabeça”. Características da depressão são identificadas também na paciente 9: os aspectos depressivos aparecem na história em AG (TRO), na qual o sentimento de desesperança prevaleceu: "Sem motivo para viver: Aqui eu não imagino nada, parecem pessoas, meio perdidas... Estão no espaço, perdidas. São pessoas que não têm motivo de viver (chora)": assim como o paciente 6, que se mostra apático no exame e não pensa sobre estratégias para melhorar sua qualidade de vida: resistências 
importantes são verificadas no discurso e confirmadas no teste, como o distanciamento afetivo e a desesperança.

A paciente 10 reage com distanciamento afetivo, ironiza a condição clínica e questiona o porquê de estar viva já que o “marido faleceu com a sua idade e o médico (cardiologista) já deve ter morrido também".

No grupo $\mathrm{D}$, estruturas esquizóides são verificadas nas pacientes 1 e 2 . A paciente 1 manifesta dificuldades diante do tema de doença e morte que a leva à utilização de defesas maníacas na tentativa de aplacar a angústia: dor e sofrimento levam à desesperança e desamparo. A paciente 2 utiliza defesas arcaicas como escotomização e negação da realidade psíquica e não são encontradas ansiedades depressivas que indiquem aceitação do sofrimento devido a doença e, consequentemente, do tratamento. Nas demais pacientes do grupo, mecanismos de defesa e sentimentos arcaicos foram frequêntes ao longo de todo o exame.

Os pacientes mais graves trouxeram em suas histórias de vida relatos de situações em que a simbolização não aconteceu e, no momento de crise, estes aspectos são agravados.

A experiência que permite o saber é possível a partir da compreensão da relação de cada sujeito com sua subjetividade. De acordo com Moretto (2006), o enxerto do novo órgão na situação de transplante não corresponde à sua incorporação.

Alguns pacientes do grupo A por vezes apresentaram pontuações baixas, no entanto, é possível considerar que dispõem de recursos internos para a superação do conflito e capacidade de simbolização, uma vez que buscaram por análise pessoal. Mesmo desconhecendo o que é latente na queixa, identificam que algo "não vai bem" e procuram tratamento. A capacidade de elaboração depressiva requer esta apreensão do sofrimento pela perda objetal. 
Pacientes que procuram análise podem se mostrar mais adaptados, com recursos internos de enfrentamento. Podemos postular que, se os pacientes cardiopatas que mostram complexos processos psíquicos encontrarem um campo / espaço para a fala em situações de crise, aqueles que solicitarem uma escuta diferenciada poderão ser considerados mais adaptados (ou com melhores recursos de enfrentamento). Trata-se de uma questão importante que envolve reformulação de padrões psicológicos presentes na instituição de saúde. É o psicanalista o profissional que pode oferecer esta escuta e não outra, podendo identificar conteúdos latentes no discurso. O que para outro profissional pode soar "inofensivo", no momento em que a escuta psicanalítica se faz presente, problemas na fala são identificados.

Como exemplo, é possível citar o registro de prontuário do paciente 2 (Grupo C), que dizia "seguirá orientações, aderido ao tratamento e sem demanda para seguimento psicoterápico" . Na entrevista, o paciente diz: “meus filhos me ajudam muito com o tratamento, estão sempre me lembrando dos remédios”. O que num primeiro momento parece saudável em termos da dinâmica e apoio familiar, é preocupante na avaliação psicanalítica que permitiu a escuta para além do que foi dito: ao consultar sobre a ocupação dos filhos, verificou-se que trabalham em jornadas longas, são casados, residem em municípios diferentes. Se a manutenção da saúde do paciente é garantida pelo auxílio dos filhos, quando ausentes o tratamento será cessado e o paciente deixará de tomar as medicações e seguir com orientações médicas. A problemática precisa ser levada à equipe a fim de garantir adesão ao tratamento, trazendo à consciência o que é latente no discurso. As particularidades da dinâmica psíquica são verificadas e compreendidas como prováveis não só aqui / agora, mas em outras esferas da vida do paciente: a compreensão da psicodinâmica é importante para o prognóstico de qualquer paciente. 
Esta é a importância da contribuição da avaliação psicanalítica: identificar o quê no discurso poderá comprometer o prognóstico e atuar com medidas preventivas. O que se propõe é um espaço de escuta para a população estudada, a criação de um protocolo de avaliação diagnóstica de base psicanalítica no qual devem ser contemplados os saberes do profissional a fim de identificar os processos psicodinâmicos decorrentes do diagnóstico clínico. Sugere-se a ampliação da clínica, do campo de atuação, que poderá auxiliar a equipe multidisciplinar quanto às intervenções imediatas que implicam em fazer o paciente reconhecer sua demanda sem saber que ela existia.

Na instituição de saúde, a questão do tempo para intervenções é diferente e, nestes casos, o TRO se mostra instrumento útil / eficaz para a identificação das relações objetais dos pacientes, assim como a avaliação proposta pela EDAO (Simon, 2005), favorável em ambientes como o hospitalar. A escala AGF do DSM - IV (Associação Americana de Psiquiatria [APA], 2002) pode ser associada à EDAO de Simon (2005) ao fazer inferências acerca da adaptação global do paciente, formulando hipóteses sobre padrões psicodinâmicos que se cristalizaram sob a forma de complexos mecanismos inconscientes que influenciam nas respostas atuais.

O TRO demonstra a evolução de que o paciente é capaz ao analisarmos as histórias narradas que vão da lâmina A1 até a Branca. Defesas diminuem no decorrer do teste e alguns pacientes são capazes de entrar em contato com conteúdos internos significativos, principalmente aqueles em que há tentativa de diminuição da clivagem. Esta evolução, se observada ao longo do TRO, pode ser conquistada no momento em que a avaliação psicanalítica se interpõe entre o paciente e sua doença. O trabalho com os aspectos arcaicos e a identificação do objeto interno vingativo no processo, como afirma Rosa (2005) pode contribuir para melhora significativa, ao estimular o autocuidado, o contato com a doença e 
seus desdobramentos, o conhecimento da relação entre o mundo interno e o externo: o mundo interno pode deixar de ser caótico e adquirir reorganização para o enfrentamento da condição clínica.

A história clínica pode ser pensada por diferentes vértices. Inicialmente, o profissional busca oferecer uma escuta para o paciente, não se prendendo aos aspectos orgânicos. Os sintomas são incluídos na história de vida e o adoecer não deve ser visto como acontecimento casual, mas como revelador de sofrimento. A postura sócio - psicossomática, de acordo com Campos e Rodrigues (2005), possibilita escutar o conteúdo latente do discurso, aquele que não encontra expressão verbal, criando condições para que seja formulado em palavras, tornando-se manifesto. O TRO, somado à entrevista clínica, facilita este processo.

Ouvir a angústia do paciente é importante instrumento diagnóstico. Naqueles em que o acesso emocional é mais difícil, está presente o mecanismo de negação. Nestes casos, como salienta Campos (1992), a solicitação por exames e medicações é mais intensa, obrigando o médico a não estruturar a doença.

A escuta dirigida ao paciente frente ao real é o que nos guia na investigação. Portanto, o sintoma é produto do paciente. O paciente é singular e, aquilo que o profissional identifica como latente, serve para a sua compreensão e não para quem diz. A ansiedade em devolver sentidos deve ser evitada para que seja possível entender o caminho do sintoma. Não é possível compreender objetivamente o fenômeno sem incluir os aspectos subjetivos que o interpões, incluir o paciente (Moretto, 2006). Assim, foi possível estabelecer as correlações entre os grupos estudados, no processo saúde - doença, sem a pretensão de atribuir causalidade aos fatos. 
Quando não há condição para a simbolização (e muitos pacientes trazem o histórico de que isso nunca foi conquistado), há espaço para a formação de sintomas, o que foi identificado com maior frequência nos grupos mais graves de DCV (C e D).

O corpo pode manifestar o que a consciência não sabe. Os fatores subjetivos em relação à capacidade de elaboração originam doenças. $\mathrm{O}$ inconsciente tem parcela no adoecimento humano porque não há dicotomia mente - corpo e a desorganização que impede a palavra pode levar ao sofrimento psíquico. As doenças dizem sobre as dificuldades encontradas na adaptação às mudanças do mundo interno e externo: expressam e revelam as interações entre estes mundos, sendo suficientemente expressivas a ponto de provocar expressão física. Não quer dizer que os conflitos sejam inteiramente responsáveis pela sintomatologia, mas devem ser considerados no tratamento do paciente uma vez que os sintomas podem estar presentes ao longo da vida e a enfermidade não se constitui como evento isolado, e sim como um complemento de uma história.

A construção de demandas, a partir da investigação psicanalítica, é realizada a partir da compreensão da relação estabelecida entre o doente e a doença, entre o paciente e seu sofrimento corporal ou psíquico e, só é possível, se os profissionais se afastarem da má prática que limita o potencial da clínica psicanalítica, dando lugar a uma nova postura profissional, como afirma Maluf (2007).

Fantasias inconscientes específicas, relações objetais arcaicas e aspectos psicossomáticos que impedem a expressão / simbolização que levam à formação de sintomas podem atuar como FR na DCV. Pensar em fantasias de mutilação em pacientes candidatos ao TC é, no mínimo, ambivalente. Pensar em não trabalhar as fantasias (tratar o paciente), é ignorar a relação que estabeleceu com a doença, tornando a espera por um procedimento, momento que revela um componente real de preocupação em termos de sobrevida, ainda mais 
angustiante. Por fim, podemos indagar sobre a representação psíquica do coração nas cardiopatias: é por ser, justamente o coração, um órgão tão carregado de simbologia e depositário das mais diversas fantasias, que o processo de simbolização fica comprometido quando este órgão é o principal afetado nas DCV. 


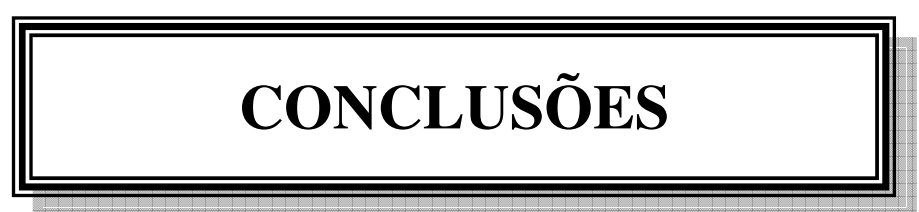




\section{CONCLUSÕES}

"Quanto mais perto do fim eu chego, mais tenho certeza de que a esperança é o meu melhor investimento."

Nietzsche, F. W.

Praticar a saúde no sentido amplo, como condição de bem estar biopsicossocial proposta pela Organização Mundial da Saúde (OMS) é um grande desafio. Em termos psicanalíticos, é quase impossível pensar nesta condição humana... O conceito parece visar uma perfeição inatingível... Neste estudo, foram pensadas as questões ligadas ao equilíbrio adaptativo dos pacientes, aos processos psíquicos desencadeados pela unidade corpo - mente. Cuidar do paciente é respeitar a sua subjetividade: conhecer valores introjetados e a cultura a qual pertence permite compreender o desejo que permeia na relação que estabelece com a manutenção da doença ou recuperação de saúde.

O presente estudo contribuiu para a análise dos processos psíquicos desencadeados em diferentes estágios de DCV, especialmente de IC. Foi possível avaliar a natureza das relações objetais e das fantasias inconscientes nos grupos de cardiopatas em relação à pacientes sem evidência da doença. $\mathrm{O}$ estudo partiu de uma proposta de investigação psicanalítica referente ao mundo interno do paciente, da observação da atividade do inconsciente em relação ao mundo externo e visou o reconhecimento dos fatores subjetivos envolvidos na construção dos sintomas e no agravamento da condição clínica.

A avaliação psicanalítica se demonstrou fundamental para a compreensão da psicodinâmica do paciente cardiopata, ao identificar os FR psicossociais envolvidos no 
processo saúde - doença, e levando este olhar diferenciado ao conhecimento da equipe. A técnica psicanalítica empregada nestas condições poderá estimular a equipe a conviver com patologias mais sutis, de expressão mental, sendo utilizada como alicerce de um tratamento que transcende a cura de doenças, recuperando o modelo hipocrático de tratar doentes no qual a doença é originada e segue seu curso para além dos limites biológicos.

É possível pensar que, o fato de existir um acometimento cardíaco, devido ao estabelecimento de uma relação diferenciada do cardiopata com o coração doente, é suficiente para que todos estes fatores apareçam, podendo se agravar nos estágios avançados da doença.

Pacientes em estágios mais avançados de DCV apresentam aspectos psicossomáticos expressivos, relações objetais e fantasias inconscientes predominantemente das fases arcaicas do desenvolvimento, esquizoparanóide e viscocárica.

Fantasias inconscientes e relações objetais arcaicas podem ser encontradas em estágios menos avançados de DCV. No entanto, fantasias inconscientes de mutilação são peculiares nos pacientes do grupo D, candidatos ao TC.

O diagnóstico diferencial de base psicanalítica para identificar o estado emocional de pacientes cardiopatas pode fornecer dados sobre a adesão do paciente ao tratamento, sobre as fantasias que podem interferir no pré e pós operatório cirúrgico e os cuidados que serão dispensados, avaliando os prejuízos identificados no autocuidado. Uma evolução clínica satisfatória com controle destes FR é determinante de um prognóstico mais favorável.

A identificação da precariedade do funcionamento mental, nos diferentes estágios da cardiopatia, aponta para a necessidade de instauração imediata de psicoterapia.

O protocolo de avaliação psicanalítica sugerido pressupõe redução dos sintomas e promoção de saúde mental, com a compreensão dos aspectos psicossomáticos envolvidos na relação paciente - doença e a identificação dos processos psíquicos arcaicos (relações objetais 
e fantasias inconscientes primitivas) frente à condição clínica, levando ao conhecimento da equipe os achados que são considerados como FR na DCV. 


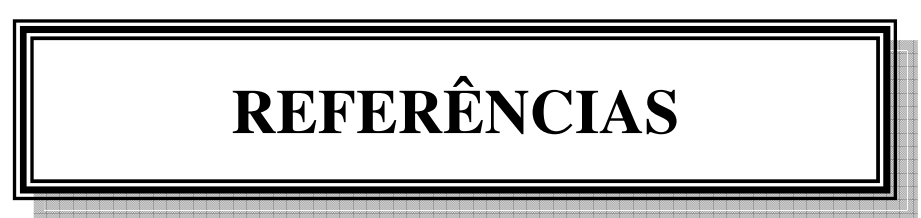




\section{REFERÊNCIAS}

Abraham, K. (1924). The influence of oral erotism on character formation. Select papers on psychoanalysis. London: Hogarth Press.

Albus, C. (2010). Psychological and social factors in coronary heart disease. Ann Med., 42(7), 487-94.

Alexander, F. (1989). Medicina psicossomática. Porto Alegre: Artes Médicas.

Associação Americana de Psiquiatria - APA. (2002). Manual diagnóstico e estatístico de transtornos mentais - DSM-IV. Porto Alegre: Artmed. 4 ed.

Angold, A., Costello, J. E., \& Erkanli, A. (1999). Comorbidity. Journal Child. Psychol. Psychiat., 40(1), 57-87.

Areosa, C. M., Almeida, D. R., Carvalho, A. C., \& Paola, A. A, (2007). Evaluation of heart failure prognostic factors in patients referred for heart transplantation. Arq. Bras. Cardiol., 88(6), 667-673.

Arrais, A. R., Oliveira, A. P. S. V., \& Paula, F. T. M. (2012). O atendimento psicológico de adultos e idosos com quadros psicossomáticos no pronto-socorro de um hospital. Psicologia e Saúde, 4, 77-84.

Arzeno, M. E. G. (1983). La fantasía de enfermedad, curación y análisis: su importância clínica y su diagnóstico através del test de relaciones objetales de H. Phillipson. Atualizaciones en el TRO. Argentina, Buenos Aires: Paidos.

Avezum, A., Yusuf, S., Hawken, S., Ôunpuu, S., Dans, T., et al. (2004). Effect of potentially modifiable risk factors associated with myocardial infarction in 52 countries (the interheart study): case-control study. Lancet, 364, 937-952. 
Avezum, A., Piegas, L. S., Pereira, J. C. R., Rossi Neto, J. M., Hoepfner, C., et al. (2003). Risk factors for myocardial infarction in Brazil. American Heart Journal, 146(2), 331338.

Avezum, A., Piegas, L. S., \& Pereira, J. C. R. (2005). Fatores de risco associados com infarto agudo do miocárdio na região metropolitana de São Paulo: uma região desenvolvida em um país em desenvolvimento. Arquivos Brasileiros de Cardiologia, 84(3), 206-213.

Avezum, A., O`Donnell, M. O., Xavier, D., Diener, C., Sacco, R., et al. (2010). Rationale and design of interstroke: a global case-control study of risk factors for stroke. Neuroepidemiology, 35, 36-44.

Bacal, F., Souza-Neto, J. D., Fiorelli, A. I., Mejia, J., Marcondes-Braga, F. G., Mangini, S., et al. (2009). II Diretriz Brasileira de Transplante Cardíaco. Arquivos Brasileiros de Cardiologia, 94, 16-73.

Ballone, G. J. (2007). Cardiologia e emoções. In: PsiqWeb. Disponível em http://www.psiqweb.med.br.

Barbosa, V. C., \& Randomile, M. E. S. (2006). Ansiedade pré-operatória no hospital geral. Revista Virtual de Psicologia Hospitalar e da Saúde, 2, 45-50.

Barefoot, J. C., Helms, M. J., Mark, D. B., Blumenthal, J. A., Califf, R. M., et al. (1996). Depression and long-term mortality risk in patients with coronary artery disease. Am. J. Cardiol., 78, 613-617.

Barriball, K. L., \& While, A. (1994). Collecting data using a semi-structured interview: a discussion paper. Journal of Advanced Nursing, 19, 328-335.

Brezinka, V., \& Kittel, F. (1996). Psychosocial factors of coronary heart disease in woman: a review. Soc. Sci. Med., 42(10), 1351-1365. 
Bleger, J. (1988). Simbiose e ambiguidade: estudo psicanalítico. Rio de Janeiro: Francisco Alves.

Bocchi, E. A., Marcondes-Braga, F. G., Bacal, F., Ferraz, A. S., Albuquerque, D., Rodrigues, D., et al. (2012). Atualização da diretriz brasileira de insuficiência cardíaca crônica. Arq. Bras. Cardiol., 98(1) supl.1.

Bonomo, A. M. S., \& Araujo, T. C. C. F. (2009). Psicologia aplicada à cardiologia: um estudo sobre emoções relatadas em exame de Holter. Psicologia: Teoria e Pesquisa, 25, 65-74.

Bowling, A. (2001). Research methods in health: investigating health and health services. Buckingham: Open University Press.

Brandwin, M., Trask, P., Schwartz, S., \& Clifford, M. (2000). Personality predictors of mortality in cardiac transplant candidates and recipients. J. Psychosom Res., 49(2), 141147.

Campos, E. P. (1992). Aspectos psicossomáticos em cardiologia. Psicossomática hoje. Porto Alegre: Artes Médicas.

Campos, E. M. P., Bach, C., \& Alvares, M. (2003). Estados emocionais do paciente candidato a transplante de medula óssea. Psicol. Teoria e Prática, 5(2), 23-36.

Campos, E. M. P., \& Rodrigues, A. L. (2005). Mecanismo de formação dos sintomas em psicossomática. Mudanças - Psicologia da Saúde, 13(2), 271-308.

Campos, S. V., Strabelli, T. M., Amato, N. V, Bocchi, E. A.., Bacal, F., et al. (2008). Risk factors for Chagas disease reactivation after heart transplantation. J. Heart Lung Transplant., 27(6), 597-602.

Caper, R. (1990). A identificação projetiva e a formação do mundo interno. Fatos imateriais. Rio de Janeiro: Imago. 
Cardoso, N. M. P. (1995). Doença oncológica e alexitimia: contributo pessoal. Dissertação de Mestrado. Unidade de Psicologia. Universidade de Coimbra.

Carney, R. M., Saunders, R. D., Freedlande, K. E., Steim, P., Rich, M. W., \& Jaffe, A. S. (1995). Association of depression with reduced heart rate variability in coronary artery disease. Am. J. Cardiol., 76, 562-564.

Cerchiari, E. A. N. (2000). Psicossomática: um estudo histórico e epistemológico. Psicologia: Ciência e Profissão, 20(4), 64-79.

Da Silva, J. V. D. V., Rosa, J. T., Paegle, I. C., Braunholz, M. A. S., \& Bolgar, M. F. (2004). Contribuições do Teste de Relações Objetais de Phillipson para o diagnóstico do funcionamento mental de pacientes com transtorno de pânico. Psic [online], 5(1), 48-65.

Della Nina, M. (2004). O psicanalista, a clínica e o psicossomático. Revista Brasileira de Psicanálise, 38, 693-710.

Deng, M. C., De Meester, J. M. J., Smits, J. M. A., Heinecke, J., \& Scheld, H. H. (2000). Effect of receiving a heart transplant: analysis of a national cohort entered on a waiting list, stratified by heart failure severity. Comparative Outcome and Clinical Profiles in Transplantation (COCPIT) Study Group. BMJ, 2(321), 540-545.

Dias, C. A. (1992). Aventuras de Ali-Babá nos túmulos de Ur: ensaio psicanalítico sobre somatopsicose. Lisboa: Fenda Edições.

Dickstein, K., Cohen-Solal, A., Filippatos, G., McMurray, J., Ponikowski, P., Poole-Wilson, P., et al. (2008). ESC guidelines for the diagnosis and treatment of acute and chronic heart failure 2008: the Task Force of the European Society of Cardiology. Developed in collaboration with the Heart Failure Association of the ESC (HFA) and endorsed by the European Society of Intensive Care Medicine (ESICM). Eur J Heart Fail, 10(10), 93389.

Dunbar, H. F. (1943). Psychosomatic diagnoses. New York: Hoeber. 
Dutra, O. P. (2006). II Diretriz brasileira de cardiopatia grave. Arquivos Brasileiros de Cardiologia [online], 87(2), 223-232.

Eksterman, A. (1978). O médico como psicanalista. Contribuições psicanalíticas à medicina psicossomática. (Vol. 1). São Paulo: ABMP.

Eksterman, A. (1992). Psicossomática: o diálogo entre a psicanálise e a medicina. Psicossomática hoje. Porto Alegre: Artes Médicas.

Etchegoyen, R. H. (1987). Transferência. Fundamentos da técnica psicanalítica. Porto Alegre: Artes Médicas.

Figueiredo, L. C. (2006). A clínica psicanalítica a partir de Melanie Klein: o que isto pode significar? Jornal de Psicanálise, 39(71), 125-150.

Frasure - Smith, N., Lesperance, F., \& Talajie, M. (1995). Depressiom and 18-month prognosis after myocardial infarction. Circulation, 91(4), 999-1005.

Freud, S. (1996a). Estudos sobre a histeria. (J. Salomão, Trad.). Edição Standard Brasileira das Obras Psicológicas Completas de Sigmund Freud (Vol. 2). Rio de Janeiro: Imago. (Original publicado em 1893-1895).

Freud, S. (1996b). Luto e melancolia. (J. Salomão, Trad.). Edição Standard Brasileira das Obras Psicológicas Completas de Sigmund Freud (Vol. 14). Rio de Janeiro: Imago. (Original publicado em 1917).

Freud, S. (1996c). Além do princípio do prazer. (J. Salomão, Trad.). Edição Standard Brasileira das Obras Psicológicas Completas de Sigmund Freud (Vol. 18). Rio de Janeiro: Imago. (Original publicado em 1920).

Freud, S. (1996d). Sobre os critérios para destacar da neurastenia uma síndrome particular intitulada neurose de angústia. (J. Salomão, Trad.). Edição Standard Brasileira das Obras 
Psicológicas Completas de Sigmund Freud (Vol. 3). Rio de Janeiro: Imago. (Original publicado em 1894-1895).

Freud, S. (1996e). A sexualidade na etiologia das neuroses. (J. Salomão, Trad.). Edição Standard Brasileira das Obras Psicológicas Completas de Sigmund Freud (Vol. 3). Rio de Janeiro: Imago. (Original publicado em 1898).

Freud, S. (1996f). Fragmento da análise de um caso de histeria: caso Dora. (J. Salomão, Trad.). Edição Standard Brasileira das Obras Psicológicas Completas de Sigmund Freud (Vol. 7). Rio de Janeiro: Imago. (Original publicado em 1905).

Freud, S. (1996g). Projeto de uma psicologia para neurologistas. (J. Salomão, Trad.). Edição Standard Brasileira das Obras Psicológicas Completas de Sigmund Freud (Vol. 3). Rio de Janeiro: Imago. (Original publicado em 1895).

Freud, S. (1996h). Sobre as afasias. (J. Salomão, Trad.). Edição Standard Brasileira das Obras Psicológicas Completas de Sigmund Freud (Vol. 7). Rio de Janeiro: Imago. (Original publicado em 1891).

Friedman, M., \& Rosenman, R. H. (1959). Association of a specific overt behavior pattern with increases in blood cholesterol, blood clotting time, incidence of arcus senilis and clinical coronary artery disease. Journal of the Amercian Medical Association, 169, 12861296.

Friedman, M. (1977). Type A behavior pattern: some of its pathophysiological components. Bulletin of the New York Academy of Medicine, 53, 593-604.

Friedman, M. (1978). Type A behavior: its possible relationship to pathogenetic processes responsible for coronary heart disease. Coronary-prone behavior. New York: SpringerVerlag.

Haynal, A. \& Pasini, W. (1980). Manual de medicina psicossomática. Barcelona, Espanha: Toray-Masson. 
Heimann, P. (1977). Dinamismos das interpretações transferenciais. Revista Brasileira de Psicanálise, 11, 93-109.

Heleno, M. G. V. (2000). Organizações patológicas e equilíbrio psíquico em pacientes diabéticos do tipo 2. Tese de Doutorado, Instituto de Psicologia, Pós-Graduação em Psicologia Clínica, Universidade de São Paulo.

Hueb, M. F. D., \& Loureiro, S. R. (2005). Revisão: aspectos cognitivos e psicossociais associados à doença de Chagas. Psicologia em Estudo, 10(1), 137-142.

Isaacs, S. (1952). On the nature and function of phantasy. Developments in Psychoanalysis. London: Hogarth Press.

Jenkins, C. D., \& Zyzansky, S. J. (1980). Behavioral risk factors and coronary disease. Psychother. Psychosom., 34, 149-177.

Jiang, W., Babyak, M., Krantz, D. S., Waugh, R. A., Blumenthal, J. A., et al. (1996). Mental stress-induced myocardial ischemia and cardiac events. JAMA, 21, 1651-1656.

Khayyam-Nekouei, Z., Neshatdoost, H., Yousefy, A., Sadeghji, M., \& Manshaee, G. (2013). Psychological factors and coronary heart disease. ARYA Atherosclerosis, 9(1), 102-111.

Klein, M. (1948). The development of a child. Contributions to psychoanalysis. London: Hogarth Press. (Original Publicado em 1921).

Klein, M. (1991a). Inveja e gratidão e outros trabalhos. Rio de Janeiro: Imago. (Original Publicado em 1975).

Klein, M. (1991b). Notas sobre alguns mecanismos esquizóides. Inveja e gratidão e outros trabalhos. Rio de Janeiro: Imago. (Original Publicado em 1946). 
Klein, M. (1991c). Inveja e gratidão. Inveja e gratidão e outros trabalhos. Rio de Janeiro: Imago. (Original Publicado em 1957).

Klein, M. (1991d). Sobre o desenvolvimento do funcionamento mental. Inveja e gratidão e outros trabalhos. Rio de Janeiro: Imago. (Original Publicado em 1958).

Klein, M. (1996a). Uma contribuição à psicogênese dos estados maníaco-depressivos. Amor, culpa e reparação. Rio de Janeiro: Imago. (Original Publicado em 1935).

Klein, M. (1996b). O luto e suas relações com os estados maníaco-depressivos. Amor, culpa e reparação. Rio de Janeiro: Imago. (Original Publicado em 1940).

Klein, M. (1997a). Estágios iniciais do conflito edipiano e da formação do superego. A psicanálise de crianças. Rio de Janeiro: Imago. (Original publicado em 1928).

Klein, M. (1997b). A psicanálise de crianças. Rio de Janeiro: Imago. (Original Publicado em 1932).

Kubzansky, L. D., \& Kawachi, I. (2000). Going to the heart of the matter: do negative emotions cause coronary heart disease? Journal of Psychosomatic Research, 48, 323-337.

Laplanche, J., \& Pontalis, J. B. (1971). Diccionario de psicoanálisis. Barcelona: Labor.

Laplanche, J., \& Pontalis, J. B. (1995). Vocabulário da psicanálise. São Paulo: Martins Fontes.

Levenson, J. L., \& Olbrisch, M. E. (1991). Psychosocial evaluation of heart transplant candidates: a international survey of process, criteria and outcomes. Journal of Heart and Lung Transplantation, 10 (6), 948-955.

McDougall, J. (1991). Teatros do corpo. São Paulo: Martins Fontes. 
Maluf, P. P. (2007). A construção de demanda por ajuda psicológica e o trabalho psicanalítico com as classes populares. Dissertação de Mestrado, Instituto de Medicina Social, Universidade do Estado do Rio de Janeiro.

Margoto, G., Colombo, R. C. R., \& Gallani, M. C. B. J. (2009). Características clínicas e psicossociais do paciente com insuficiência cardíaca que interna por descompensação clínica. Rev. Esc. Enferm. USP, 43(1), 44-53.

Marty, P., \& Muzan, M. (1983). El pensamiento operatorio. Revista de Psicoanálisis, 4, 711721.

May, H. T., Horne, B. D., Carlquist, J. F., Sheng, X., \& Joy, E. (2009). Depression after coronary artery disease is associated with heart failure. Journal of the American College of Cardiology, 53, 1440-1447.

Mehra, M., Kobashigawa, J., Starling, R., Russell, S., Uber, P., Parameshwar, J., et al. (2006). Listing criteria for heart transplantation: International Society for Heart and Lung Transplantation guidelines for the care of cardiac transplant candidates. Journal of Heart and Lung Transplantation, 25 (9), 1024-1042.

Mello-Filho, J. (1978). Concepção psicossomática: visão atual. Rio de Janeiro: Moraes.

Mello-Filho, J. (1992). Psicossomática hoje. Porto Alegre: Artes Médicas.

Moraes, B. N. (2009). Perfil, crenças, sentimentos e atitudes de familiares doadores e não doadores de órgãos. Tese de Doutorado, Faculdade de Medicina da USP, Universidade de São Paulo.

Moretto, M. L. T. (2006). O psicanalista num programa de transplante de fígado: a experiência do “outro em si”. Tese de Doutorado, Instituto de Psicologia, Pós-Graduação em Psicologia Clínica, Universidade de São Paulo. 
Muntwyler J,, Abetel G., Gruner C., \& Follath F. (2002). One-year mortality among unselected outpatients with heart failure. Eur Heart Journal, 23, 1861-1866.

O`Donnell, M. J., Xavier, D., Liu, L., Zhang, H., Chin, S. L., et al. (2010). Risk factors for ischaemic and intracerebral hemorrhagic stroke in 22 countries - the interstroke study: a case-control study. Lancet. (Publicado Online).

Ocampo, M. L. S., Arzeno, M. E. G., \& Grassano, E. N. (1981). O processo psicodiagnóstico e as técnicas projetivas. São Paulo: Martins Fontes.

Oliveira, M. F. P., \& Luz, P. L. (1992). O impacto da cirurgia cardíaca. Psicossomática hoje. Porto Alegre: Artes Médicas.

Oliveira, E. A., Santos, M. A., \& Mastropietro, A. P. (2010). Apoio psicológico na terminalidade: ensinamentos para a vida. Psicologia em Estudo, 15(2), 235-244.

Oliveira, M. P., Martins, P. D. E., Siqueira, E. J., Alvarez, G. S., Laitano, F. F., \& Pires, F. K. S. (2012). Aspectos psicológicos do paciente pós-bariátrico. Arquivos Catarinenses de Medicina, 41, 173-175.

Perestrello, D. (1974). A Medicina da pessoa. Rio de Janeiro: Atheneu.

Petersom, J. C., Williams - Russo, P. G., Charlson, M. E., \& Meyers, B. S. (1996). Longitudinal course of new onset depression after cardiac bypass surgery. Programs and abstracts of the 10th Annual International Conference on Mental Health Problems in the General Health Care Sector. National Institute of Mental Health: Bethesda.

Phillipson, H. (1981). Test de relaciones objetales. Argentina, Buenos Aires: Paidos.

Pontes, J. F. (1974). Integração dos sintomas nos planos somáticos e psico-emocional. Arq. Gastroenterol., 12 (2), 83-87.

Prates, P. R. (2005). Símbolo do coração. Rev. História, Ciência e Saúde, 12(3), 1025-1031. 
Racker, H. (1960). Los significados y usos de la contratransferencia. Estudios sobre técnica psicoanalítica. Buenos Aires: Paidós.

Rocha, F. (1989). Introduzindo o tema: a linguagem do corpo. Revista IDE, 19, 102-108.

Rodrigues, A. L. (1987). Reunião clínica do Ibepege. Arq. Gastroenterol., 24 (2).

Roger, V. L., Go, A. S., Lloyd-Jones, D. M., Benjamin, E. J., Adams, R. J., et al. (2012). Heart disease and stroke statistics - 2011 - update: a report from the American Heart Association. Circulation: Journal of the American Heart Association. Disponível em: circ.ahajournals.org/content/early/2011/12/15/CIR.0b013e31823ac046.

Rosa, J. T. (1997). Modalidades de funcionamento mental em cardiologia: uma ponte para a integração da sensorialidade à atividade de pensar. Mudanças: Psicoterapia e Estudos Psicossociais, 8(13), 103-120.

Rosa, J. T. (Org.). (2005). Atualizações clínicas do teste de relações objetais de Phillipson. São Paulo: Vetor.

Rossi Neto, J. M. (2004). A dimensão do problema da insuficiência cardíaca do Brasil e do mundo. Rev. Sociedade de Cardiologia do Estado de São Paulo, 14(1), 1-10.

Rozansky, A., Blumenthal, J. A., \& Kaplan, J. (1999). Impact of psychological factors on the pathogenesis of cardiovascular disease and implications for therapy. Circulation, 99, 2192-2217.

Segal, H. (1975). Introdução à obra de Melanie Klein. Rio de Janeiro: Imago.

Segal, H. (1982). A técnica de Melanie Klein. A obra de Hanna Segal: uma abordagem kleiniana à prática clínica. Rio de Janeiro: Imago.

Segal, H. (1996). Nova introdução. Amor, culpa e reparação. Rio de Janeiro: Imago. 
Sifneos, P. E. (1973). The prevalence of alexithymic characteristics in psychosomatic patients. Psychotherapy and Psychosomatics, 22, 255-262.

Silva, A. F. R., \& Caldeira, G. (1992). Alexitimia e pensamento operatório: a questão do afeto na psicossomática. Psicossomática hoje. Porto Alegre: Artes Médicas.

Simon, R. (1986). Introdução à psicanálise - Melanie Klein. São Paulo: Epu.

Simon, R. (1991). Impotência contratransferencial: esboço de compreensão metapsicológica. Revista brasileira de Psicanálise, 26(1/2), 15-26.

Simon, R. (2005). Psicoterapia breve operacionalizada: teoria e técnica. São Paulo: Casa do Psicólogo.

Söderberg P., Tungström S., \& Armelius B. A. (2005). Reliability of Global Assessment of Functioning ratings made by clinical psychiatric staff. Psychiatric Services, 56, 434-438.

Spillius, E. (2001). Freud and Klein on the concept of phantasy. Kleinian theory: contemporary perspective. London: Brunner - Routledge.

Steptoe, A. (1999). Psychosocial factors in the etiology of coronary heart disease. Heart, 82, 258-259.

Strachey, J. (1996). Nota do Editor Inglês. (J. Salomão, Trad.). Edição Standard Brasileira das Obras Psicológicas Completas de Sigmund Freud (Vol. 14). Rio de Janeiro: Imago. (Original publicado em 1915).

Tamagnini, E. J. G. (2009). Transplante cardíaco: sistema tensional inconsciente dominante e diagnóstico adaptativo operacionalizado de mulheres candidatas ao enxerto. Dissertação de Mestrado, Instituto de Psicologia, Pós-Graduação em Psicologia Clínica, Universidade de São Paulo. 
Theodore, A. S. (1987). Psychiatric management of acute myocardial infarction in the Coronary Care Unit. American Journal of Cardiology, 60(18), 59-67.

Theorell, T. (1973). Psychosocial factors and myocardial infarction - why and how? Advanc. Cardiol., 8, 117-131.

Torres, W. da C. (2003). A bioética e a psicologia da saúde: reflexões sobre questões de vida e morte. Psicologia: Reflexão e Crítica, 16(3), 475-482.

Wengraf, T. (2001). Qualitative research interviewing. SAGE: London. 


\section{ANEXO A \\ Escala de Avaliação Global do Funcionamento (AGF) \\ AVALIAÇÃO MULTIAXIAL - EIXO V / DSM-IV}

Considerar o funcionamento psicológico, social e ocupacional em um continuum hipotético de saúde doença mental. Não incluir prejuízo no funcionamento devido a limitações físicas (ou ambientais).

Código (Obs.: Usar códigos intermediários quando apropriado, p. ex., 4S, 68, 72)

100 Funcionamento superior em uma ampla faixa de atividades, problemas vitais jamais fora de

I controle, é procurado por outros em vista de suas muitas qualidades positivas.

91 Assintomático.

90 Sintomas ausentes ou mínimos (p. ex., leve ansiedade antes de um exame), bom funcionamento em todas as

I áreas, interessado e envolvido em uma ampla faixa de atividades, socialmente eficiente, em geral

81 satisfeito com a vida, nada além de problemas ou preocupações cotidianas ( $\mathrm{p}$. ex., uma discussão ocasional com membros da família).

80 Se estão presentes, os sintomas são temporários e consistem de reações previsíveis a estressores

I psicossociais (p. ex., dificuldade para concentrar-se após discussão em família); não mais do que leve prejuízo

71 no funcionamento social, ocupacional ou escolar (p. ex., apresenta declínio temporário na escola).

70 Alguns sintomas leves (p. ex., humor depressivo e insônia leve) OU alguma dificuldade no funcionamento

I social, ocupacional ou escolar (p. ex., faltas injustificadas à escola ocasionalmente, ou furto dentro de casa), mas

61 geralmente funcionando muito bem; possui alguns relacionamentos interpessoais significativos.

60 Sintomas moderados (p. ex., afeto embotado e fala circunstancial, ataques de pânico ocasionais) OU

I dificuldade moderada no funcionamento social, ocupacional ou escolar (p. ex., poucos amigos, conflitos

51 com companheiros ou colegas de trabalho).

50 Sintomas sérios (p. ex., ideação suicida, rituais obsessivos graves, freqüentes furtos em lojas) OU qualquer I prejuízo sério no funcionamento social, ocupacional ou escolar (p. ex., nenhum amigo, incapaz de manter 41 um emprego).

40 Algum prejuízo no teste de realidade ou na comunicação (p. ex., fala às vezes ilógica, obscura ou irrelevante) OU I prejuízo importante em diversas áreas, tais como emprego ou escola, relações familiares, julgamento,

31 pensamento ou humor (p. ex., homem deprimido evita amigos, negligencia a família e é incapaz de trabalhar; criança freqüentemente bate em crianças mais jovens, é desafiadora em casa e está indo mal na escola).

30 Comportamento consideravelmente influenciado por delírios ou alucinações OU sério prejuízo na

I comunicação ou julgamento (p. ex., ocasionalmente incoerente, age de forma amplamente imprópria,

21 preocupação suicida) OU incapacidade de funcionar na maioria das áreas (p. ex., permanece na cama o dia inteiro; sem emprego, casa ou amigos).

20 Algum perigo de ferir a si mesmo ou a outros (p. ex., tentativas de suicídio sem clara intenção de morte;

l freqüentemente violento; excitação maníaca) OU ocasionalmente não consegue manter o mínimo de higiene

11 pessoal (p. ex., suja-se de fezes) OU amplo prejuízo na comunicação (p. ex., ampla incoerência ou mutismo).

10 Perigo persistente de ferir gravemente a si mesmo ou a outros (p. ex., violência recorrente) OU inabilidade

I persistente de manter uma higiene pessoal mínima OU sério ato suicida com claro intento

1 de morte.

0 Informações inadequadas

(A pontuação do funcionamento psicológico global em uma escala de 0-100 foi operacionalizada por Luborsky na Escala de Pontuação de Saúde-Doença (Luborsky L: "'Clinicians' Judgements of Mental Health", Archives of General Psychiatry 7: 407417, 1962). Spitzer e cols. desenvolveram uma revisão da Escala de Pontuação de Saúde-Doença, chamada Escala de Avaliação Global (Global Assessment Scale [GAS]) (Endicott J, Spitzer RL, Fleiss JL, Cohen J "The Global Assessment Scale: A Procedure for Measuring Overall Severity of Psychiatric Disturbance". Archives of General Psychiatry 33:766-771, 1976). Uma versão modificada da GAS foi incluída no DSM-III-R como a Escala de Avaliação Global do Funcionamento (AGF)) 


\section{APÊNDICE A}

TESTE DE RELAÇÕES OBJETAIS
PROTOCOLO DE ANÁLISE E INTERPRETAÇÃO
(Segundo o sistema de Phillipson. Modelo Berstein)
Examinado:
Data de Nascimento:
Escolaridade:
Estado Civil:
Ocupação:
Motivo do exame:
Administrado por:
Data:
Hora:
Término:
Obserpretação:
Duração:
Nonde lâminas administradas:
Média de Tempo:
Local do Exame:

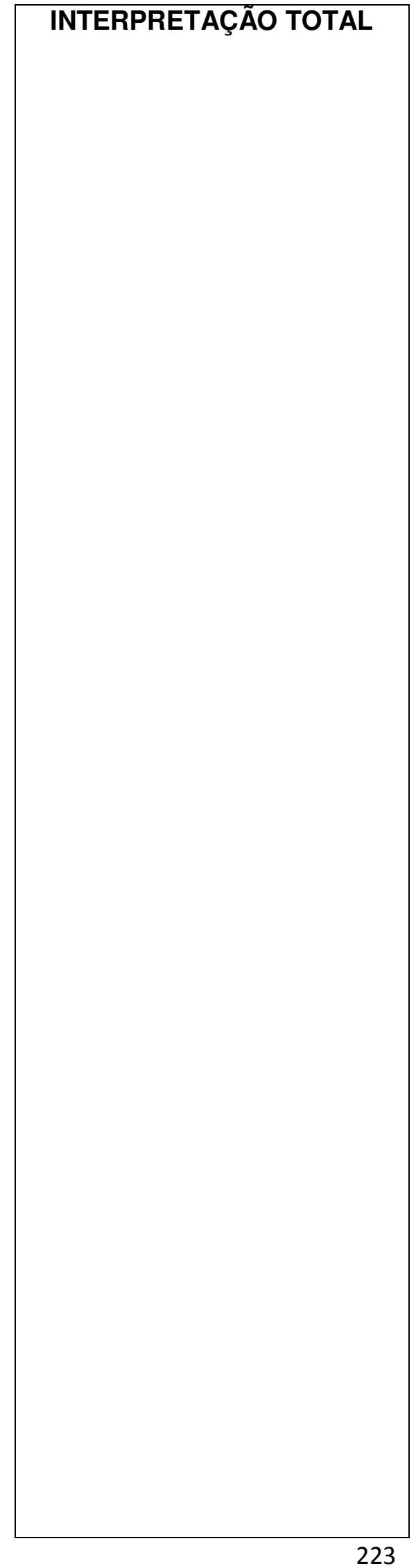




\begin{tabular}{|c|c|c|c|}
\hline \multirow[b]{2}{*}{ Lâminas } & \multicolumn{2}{|c|}{ ASPECTOS MANIFESTOS } & \multirow{2}{*}{$\begin{array}{c}\text { STID } \\
\text { Desejos } \\
\text { Inconscientes }\end{array}$} \\
\hline & $\begin{array}{l}\text { Conteúdo humano } \\
\text { (Personagens, pa- } \\
\text { péis, relacionamento }\end{array}$ & $\begin{array}{l}\text { Conteúdo de reali- } \\
\text { dade (Cenário, } \\
\text { detalhes) }\end{array}$ & \\
\hline A1 & & & \\
\hline A2 & & & \\
\hline A3 & & & \\
\hline AG & & & \\
\hline B1 & & & \\
\hline B2 & & & \\
\hline B3 & & & \\
\hline BG & & & \\
\hline C1 & & & \\
\hline $\mathbf{C 2}$ & & & \\
\hline C3 & & & \\
\hline CG & & & \\
\hline BRANCA & & & \\
\hline 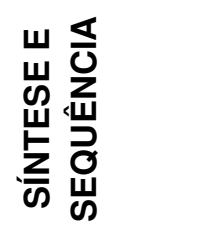 & & & \\
\hline
\end{tabular}




\begin{tabular}{|c|c|c|c|c|}
\hline \multirow{2}{*}{ Lâminas } & \multicolumn{2}{|c|}{ STID } & \multirow{2}{*}{$\begin{array}{c}\text { Interpretações } \\
\text { (Lâmina por } \\
\text { lâmina) }\end{array}$} & \multirow{2}{*}{$\begin{array}{c}\mathbf{N}^{\circ} \mathrm{de} \\
\text { Pontos }\end{array}$} \\
\hline & $\begin{array}{l}\text { Consequências } \\
\text { temidas (Medos; } \\
\text { ansiedades) }\end{array}$ & $\begin{array}{l}\text { Esforços defen- } \\
\text { sivos (Mecanis- } \\
\text { mos de defesa) }\end{array}$ & & \\
\hline A1 & & & & \\
\hline A2 & & & & \\
\hline A3 & & & & \\
\hline AG & & & & \\
\hline B1 & & & & \\
\hline B2 & & & & \\
\hline B3 & & & & \\
\hline BG & & & & \\
\hline C1 & & & & \\
\hline C2 & & & & \\
\hline C3 & & & & \\
\hline CG & & & & \\
\hline BRANCA & & & & \\
\hline & & & Sequência & $\begin{array}{l}\mathrm{N}= \\
\text { Média = } \\
\%=\end{array}$ \\
\hline
\end{tabular}




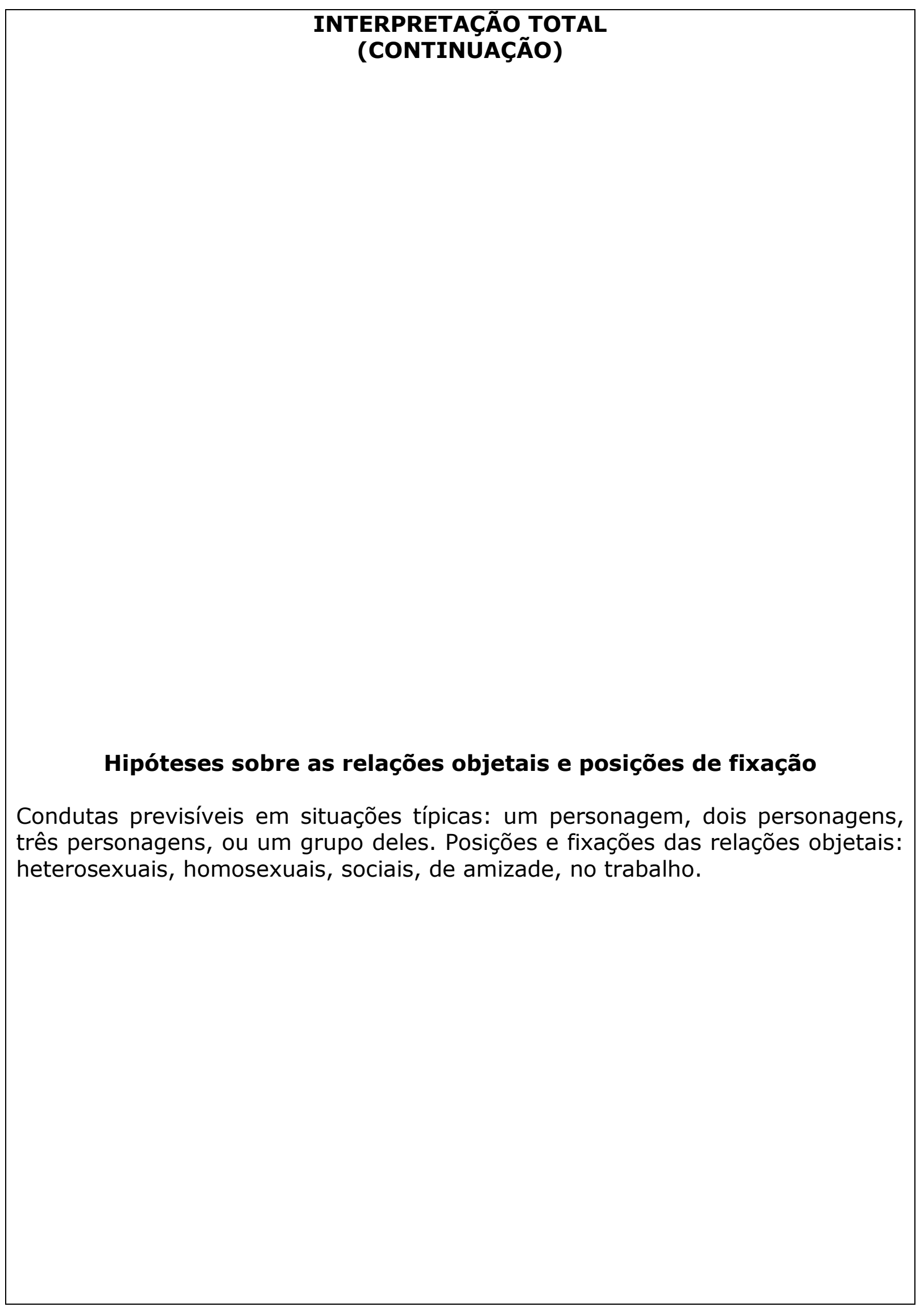




\section{APÊNDICE B \\ TERMO DE CONSENTIMENTO LIVRE E ESCLARECIDO - TCLE \\ INSTITUTO de PSICOLOGIA dA UNIVERSIDAdE dE SÃO PAULO DEPARTAMENTO dE PSICOLOGIA CLÍNICA}

DADOS DE IDENTIFICAÇÃO DO SUJEITO DA PESQUISA OU RESPONSÁVEL LEGAL

1. NOME:

DOCUMENTO DE IDENTIDADE № :

SEXO: $M() F()$

DATA NASCIMENTO:

ENDEREÇO

№

APTO:

BAIRRO:

CIDADE

CEP........

TELEFONE: DDD

)

2. RESPONSÁVEL LEGAL

NATUREZA (grau de parentesco, tutor, curador etc.)

DOCUMENTO DE IDENTIDADE :

DATA NASCIMENTO.: .........................

ENDEREÇO:

BAIRRO:

CEP:

TELEFONE: DDD

SEXO: $M($ ) $F()$

№

APTO:

\section{DADOS SOBRE A PESQUISA}

1. TÍTULO DO PROTOCOLO DE PESQUISA: CONTRIBUICÕ̃ES DA PSICANÁLISE À CARDIOLOGIA: INVESTIGANDO A PSICODINÂMICA DE CARDIOPATAS GRAVES

2. PESQUISADORA: Elisabete Joyce Galhardo Tamagnini

CARGO/FUNÇÃO: psicóloga - pesquisadora

INSCRIÇÃO CONSELHO REGIONAL: CRP 06/74106

UNIDADE DO IPUSP: Psicologia Clínica - Pós Graduação Doutorado

3. DURAÇÃO DA PESQUISA: até 6 meses (coleta de dados).

Participação voluntária: 1 a 2 encontros

- Você está sendo convidado a participar de um estudo científico, que tem como objetivo verificar o estado emocional e psicológico de pessoas que apresentam uma doença cardíaca.

- Este estudo poderá contribuir para a melhora da qualidade de vida dos pacientes que estão ou que iniciarão um tratamento. Pode haver risco de se sentir incomodado ou manifestar outras reações em ralação à presença e intervenções da psicóloga, mas, caso algum risco seja identificado, você receberá todo o suporte profissional necessário.

- Estas informações são fornecidas porque sua participação é voluntária, você terá o direito de aceitar ou recusar este convite. Você poderá desistir de fazer parte deste estudo a qualquer momento, lembrando que não há efeito prejudicial em sua recusa. Se retirar seu consentimento, não haverá qualquer prejuízo à continuidade de seu tratamento na Instituição. 
- Caso concorde em participar, você será entrevistado individualmente e responderá alguns questionários. Além dos questionários, também contará histórias a partir de figuras que serão apresentadas.

- Todas as suas respostas serão mantidas em sigilo profissional, assim como os seus dados pessoais, e somente os responsáveis pela pesquisa terão acesso a elas.

- Os resultados serão publicados, sempre respeitando o sigilo à sua identidade.

- Garantia de acesso: em qualquer etapa você poderá solicitar informações sobre o estudo ou esclarecer eventuais dúvidas. A principal investigadora é a psicóloga Elisabete Joyce Galhardo Tamagnini, que poderá ser encontrada no endereço: Av. Prof. Mello Moraes, 1721 Cidade Universitária - São Paulo (Instituto de Psicologia da USP), telefone (11) 3091-4910, e-mail: elisabetejoyce@usp.br. Caso queira mais esclarecimentos quanto às questões éticas da pesquisa, entre em contato com o Comitê de Ética em Pesquisa com Seres Humanos do IPUSP (CEP), telefone (11) 3091-4182, e-mail: ceph.ip@usp.br.

- Não há despesas pessoais para o participante em qualquer fase do estudo. Também não há compensação financeira relacionada à sua participação.

- A responsável se compromete a cumprir com todos os itens deste termo, que será entregue em 2 (duas) vias, em mãos, uma da pesquisadora e a outra do participante.

Você deverá ler e compreender este Termo antes de assiná-lo. Se for preciso, poderá pedir ajuda aos seus familiares ou à própria pesquisadora, que poderá ler com você e dar as explicações necessárias.

Eu discuti com a psicóloga Elisabete Joyce Galhardo Tamagnini sobre a minha decisão em participar do estudo. Li e compreendi as informações do Termo de Consentimento. Recebi da pesquisadora todas as explicações que solicitei. Concordo voluntariamente em participar deste estudo e poderei retirar o meu consentimento a qualquer momento, sem penalidade, prejuízo ou perda de qualquer benefício que eu possa ter adquirido em relação ao meu atendimento neste Serviço.

Data

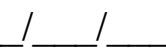

Assinatura do paciente/representante legal

(Somente para o responsável do projeto)

Declaro que obtive de forma apropriada e voluntária o Consentimento Livre e Esclarecido deste paciente ou representante legal, autorizando sua participação neste estudo.

Data 1

Assinatura/carimbo do responsável pelo estudo 